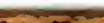

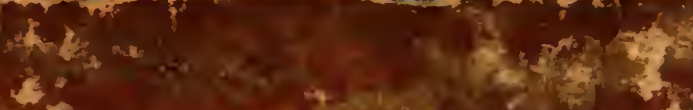

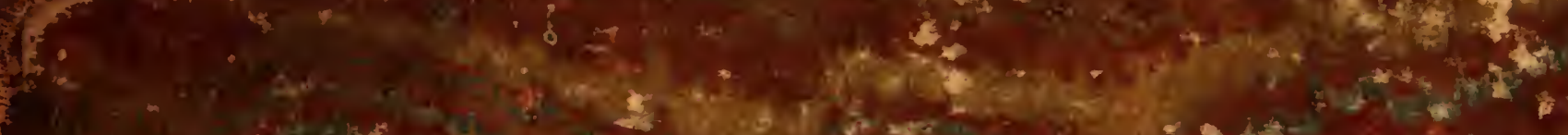

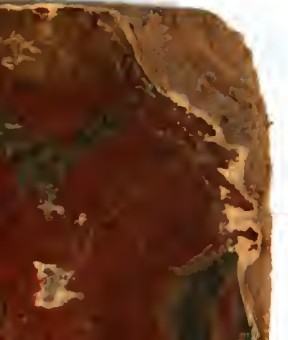

$c^{2}+20 x+3$

(3)

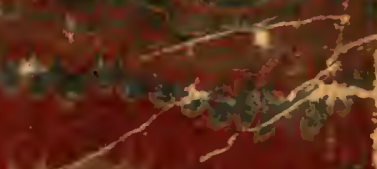

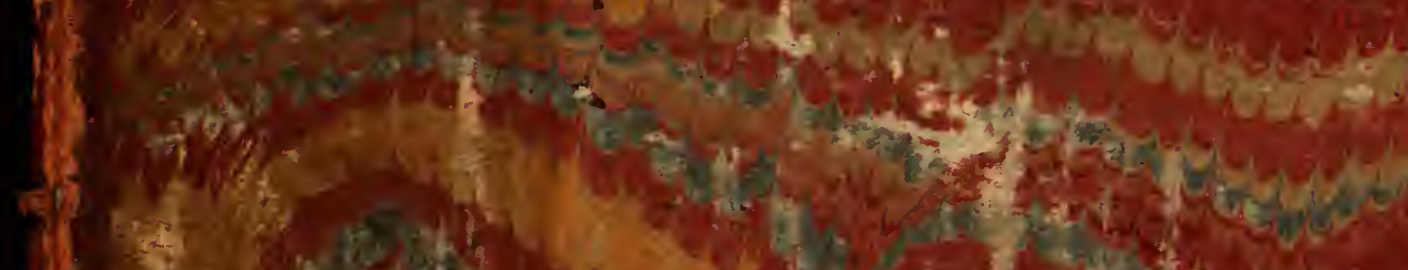

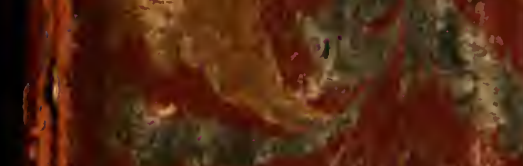

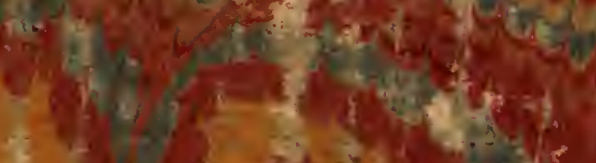

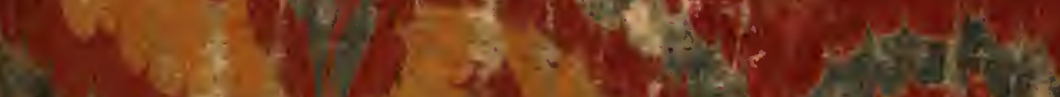

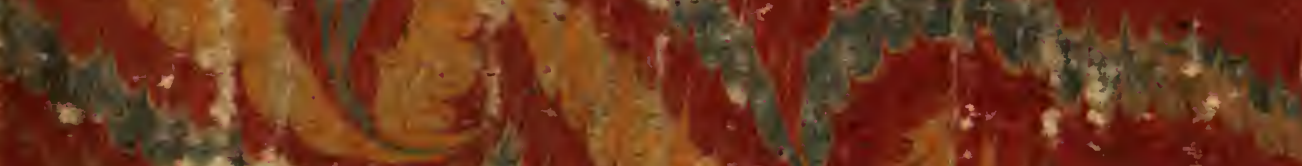

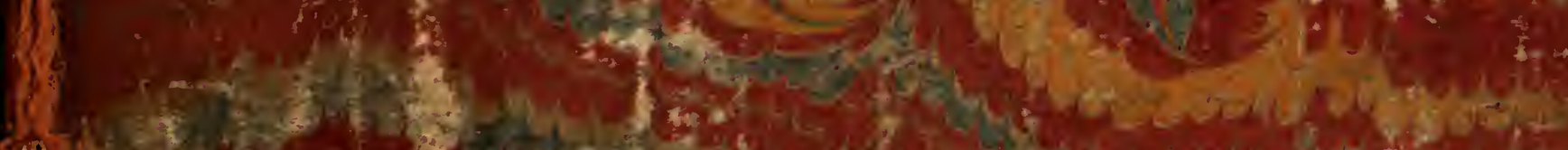

(4)

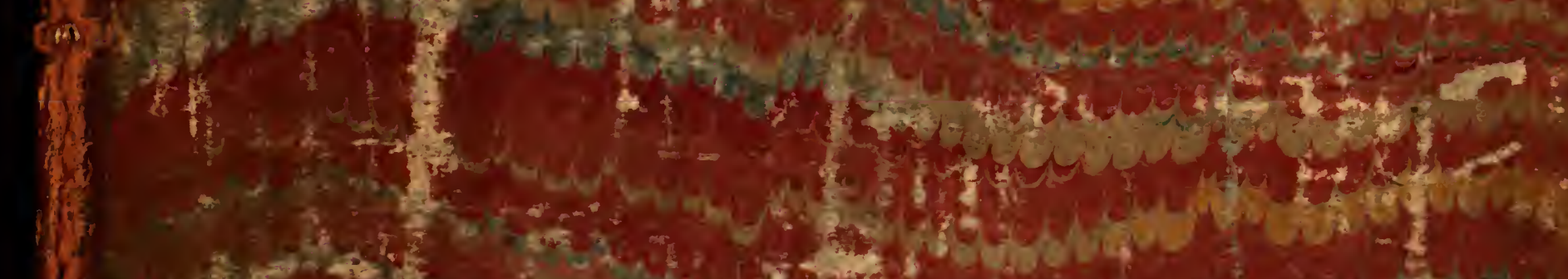

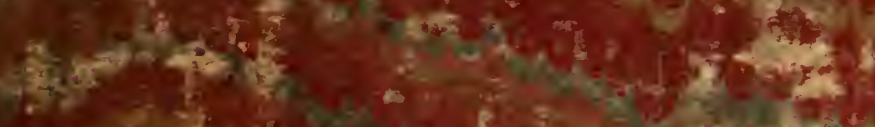

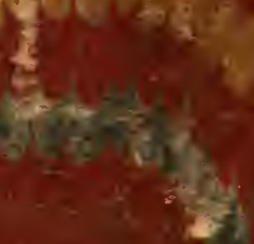

$7^{2}-y^{2}$.

2.

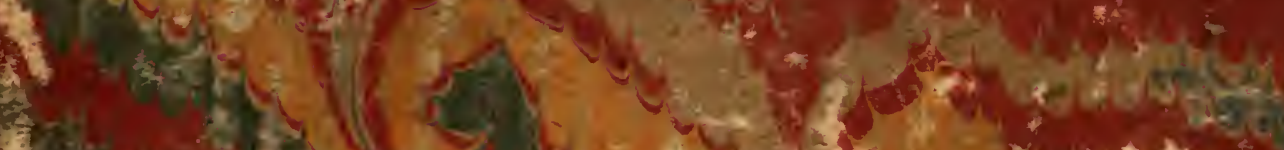

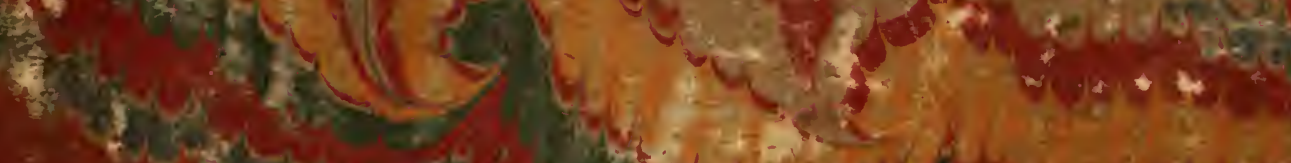

3 tat

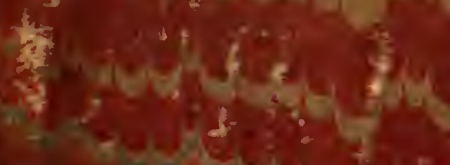

a

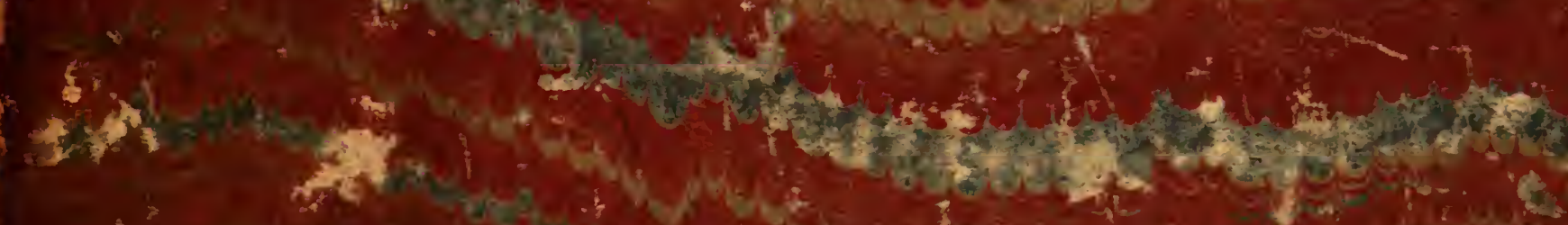

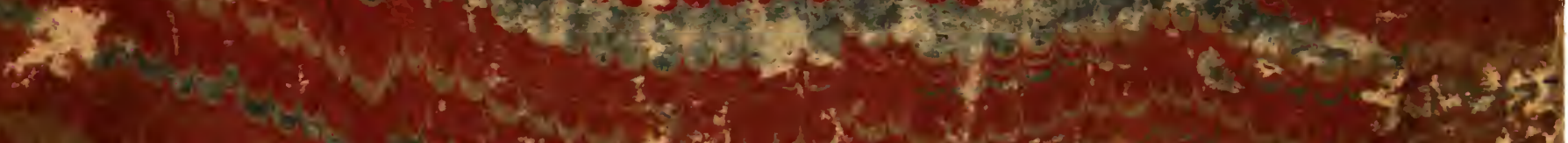

4.

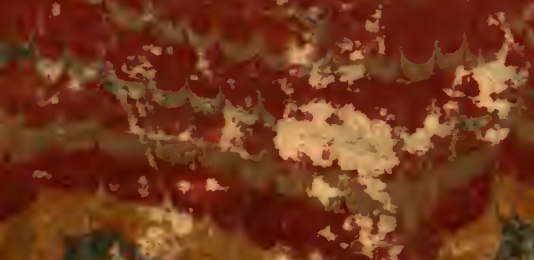

$$
\begin{aligned}
& 40-x^{2}+3
\end{aligned}
$$

(1) 


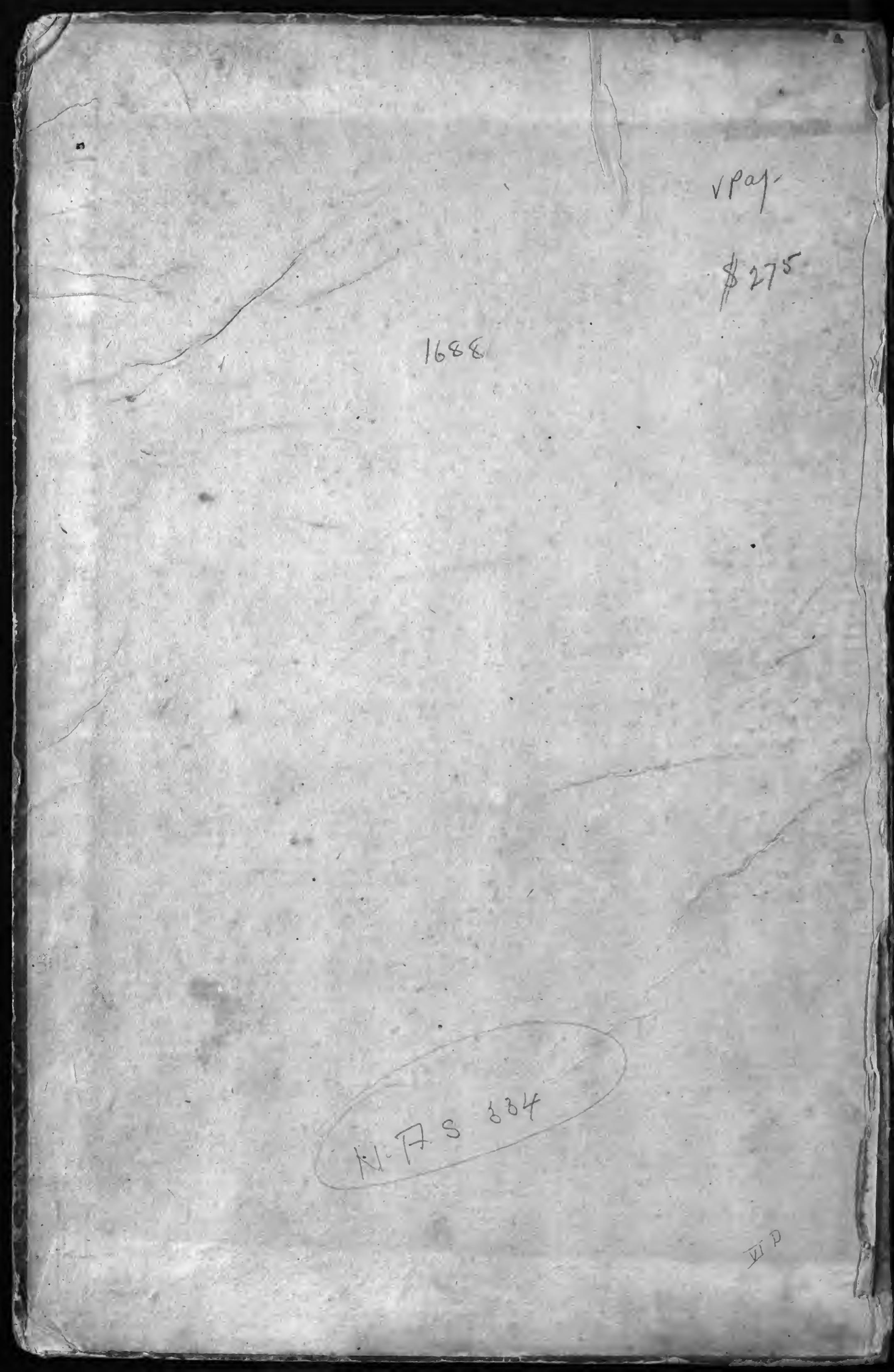




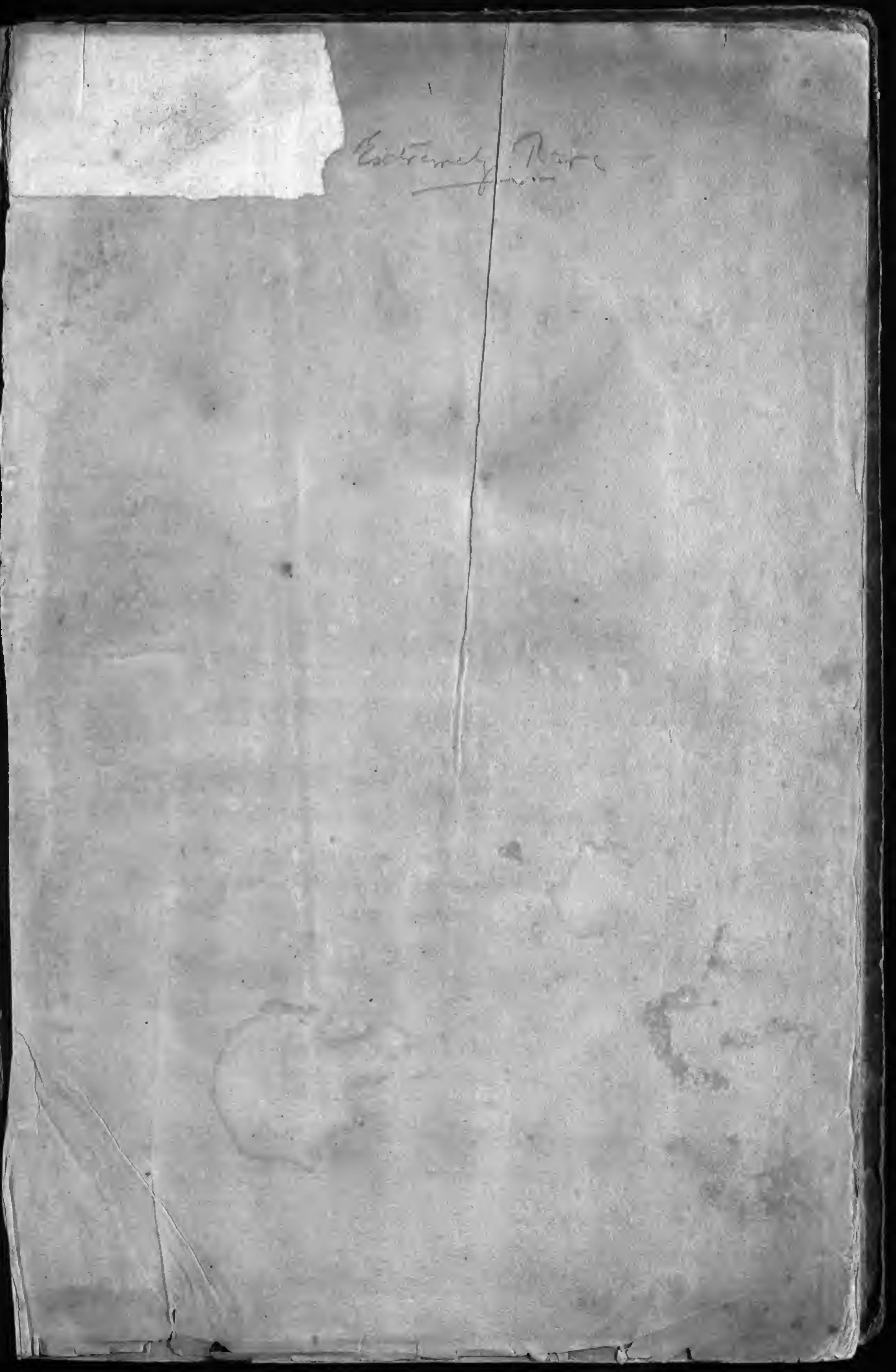




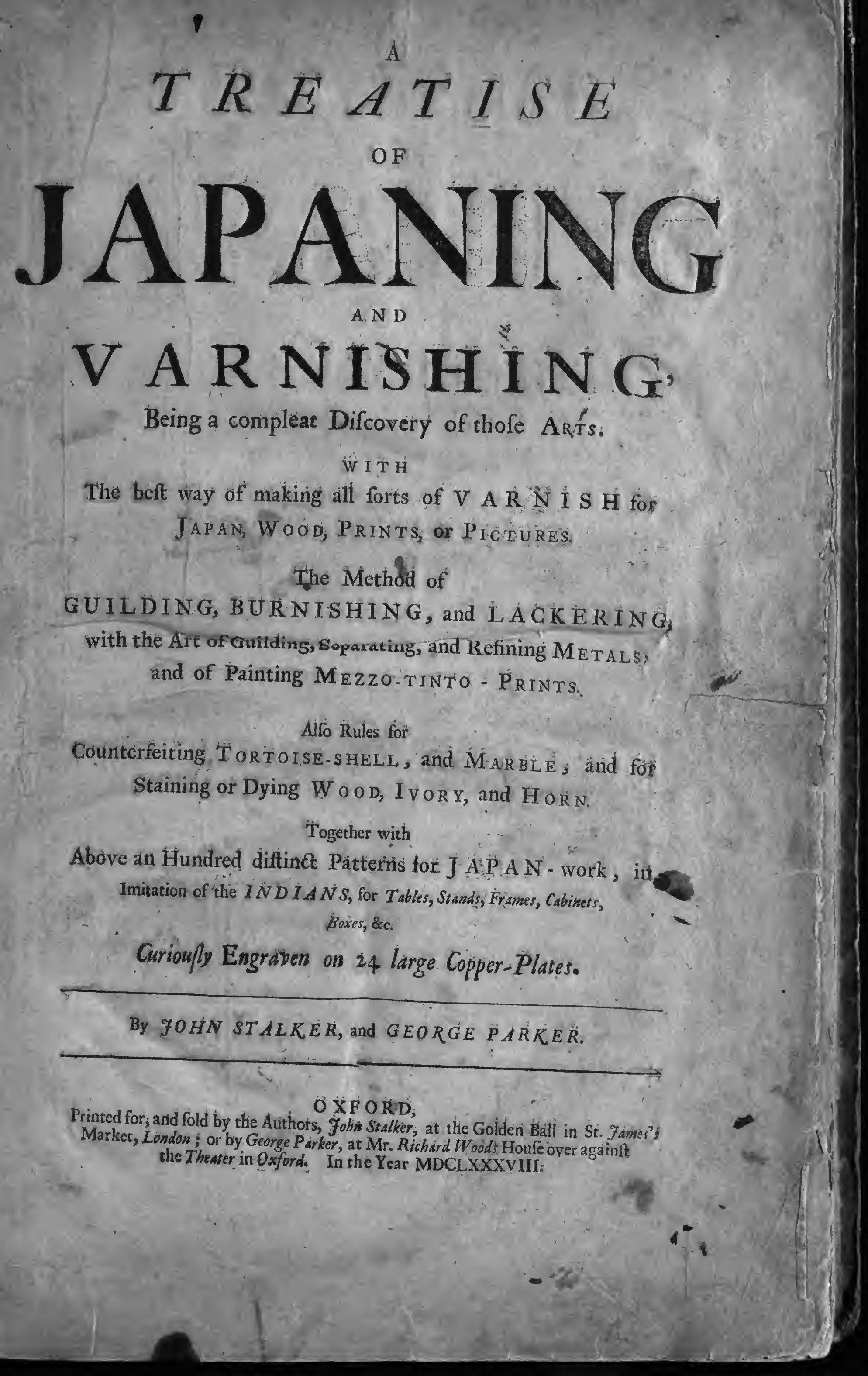


$\left(x+\frac{b}{i+\infty}\right.$

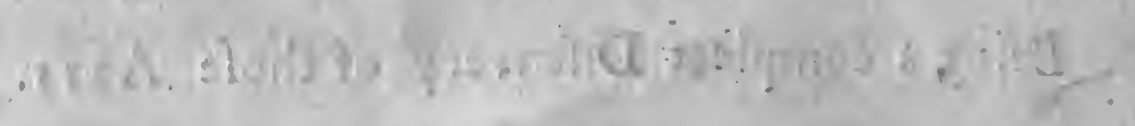

\section{FI A}
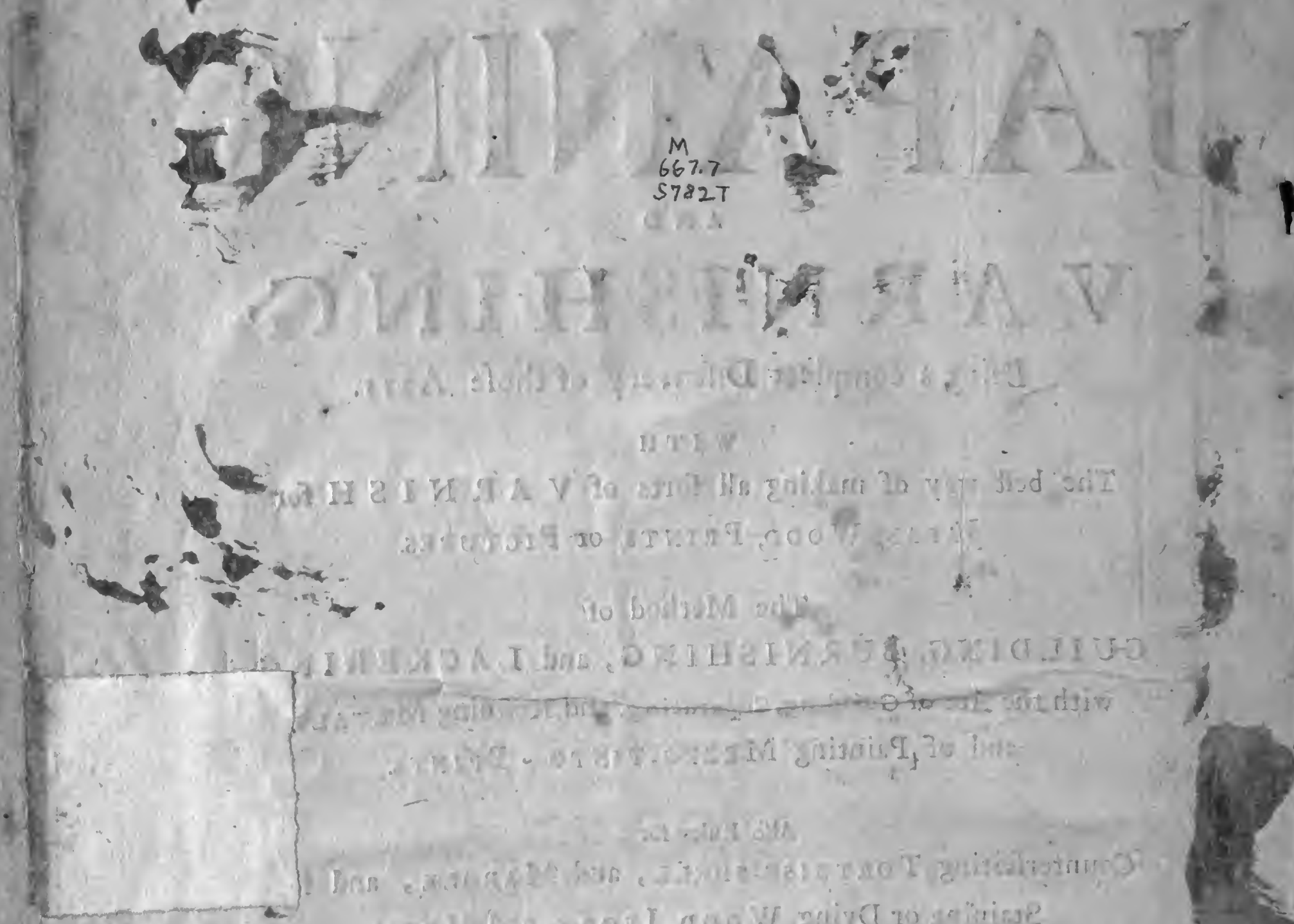

o boflisM arige.

i.

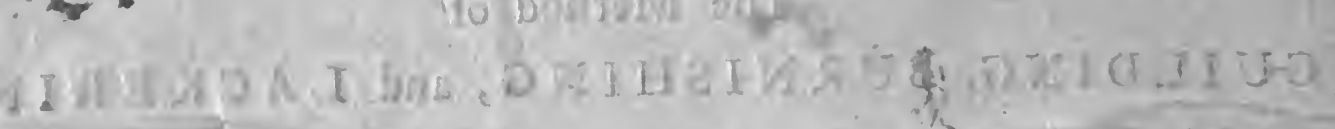

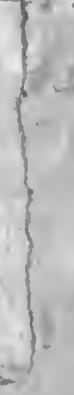

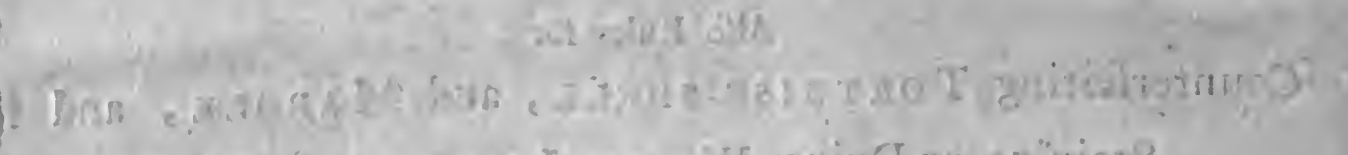

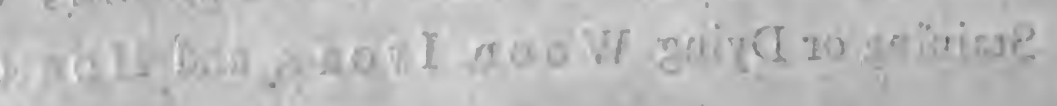

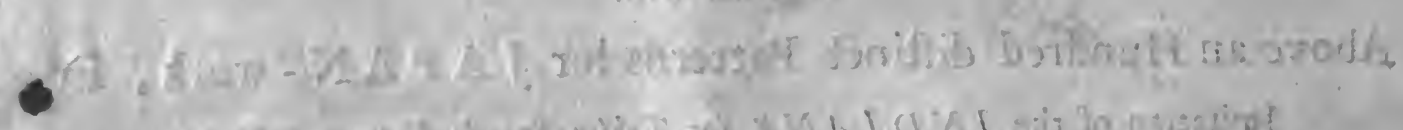
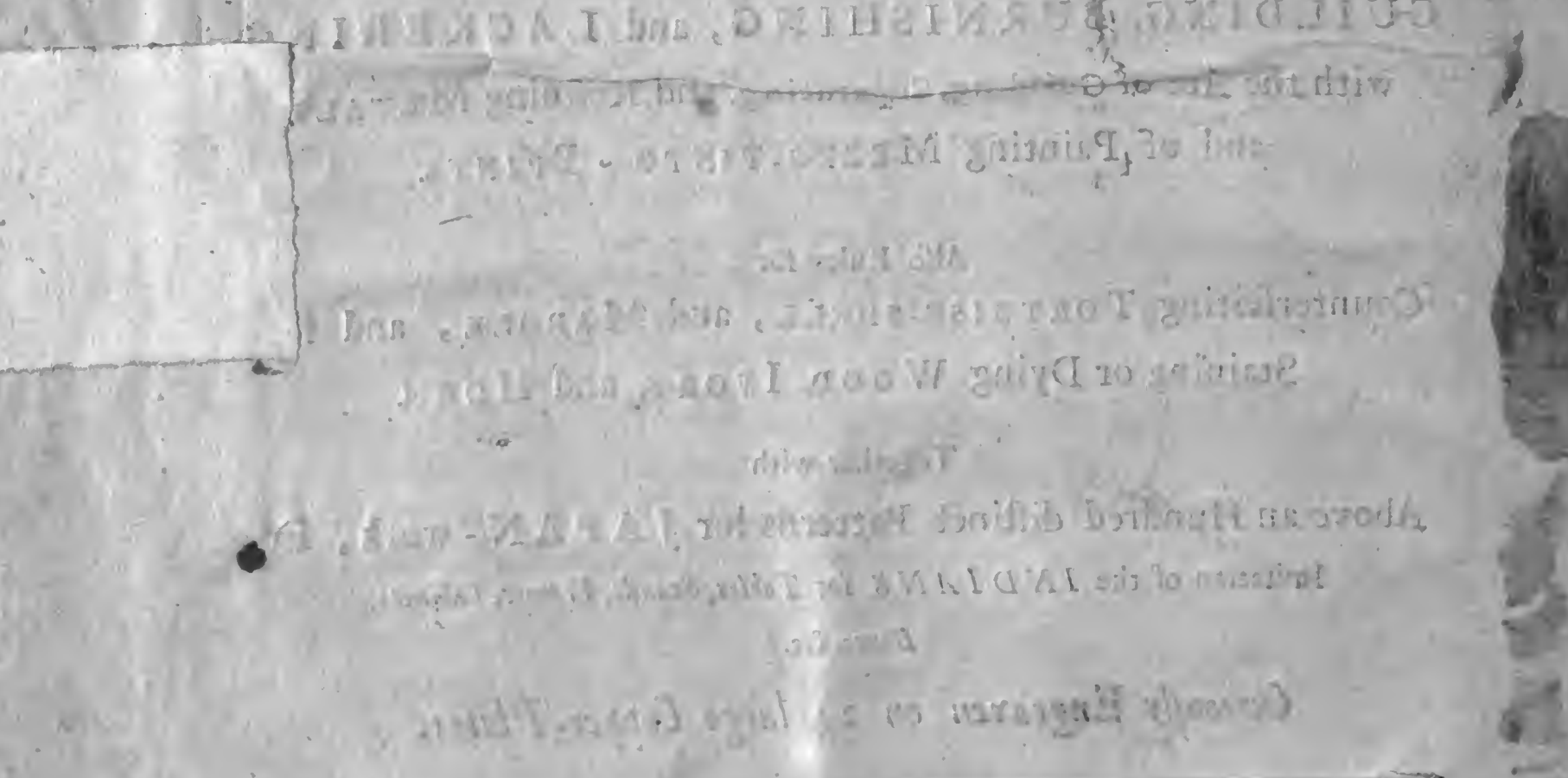

$+2$

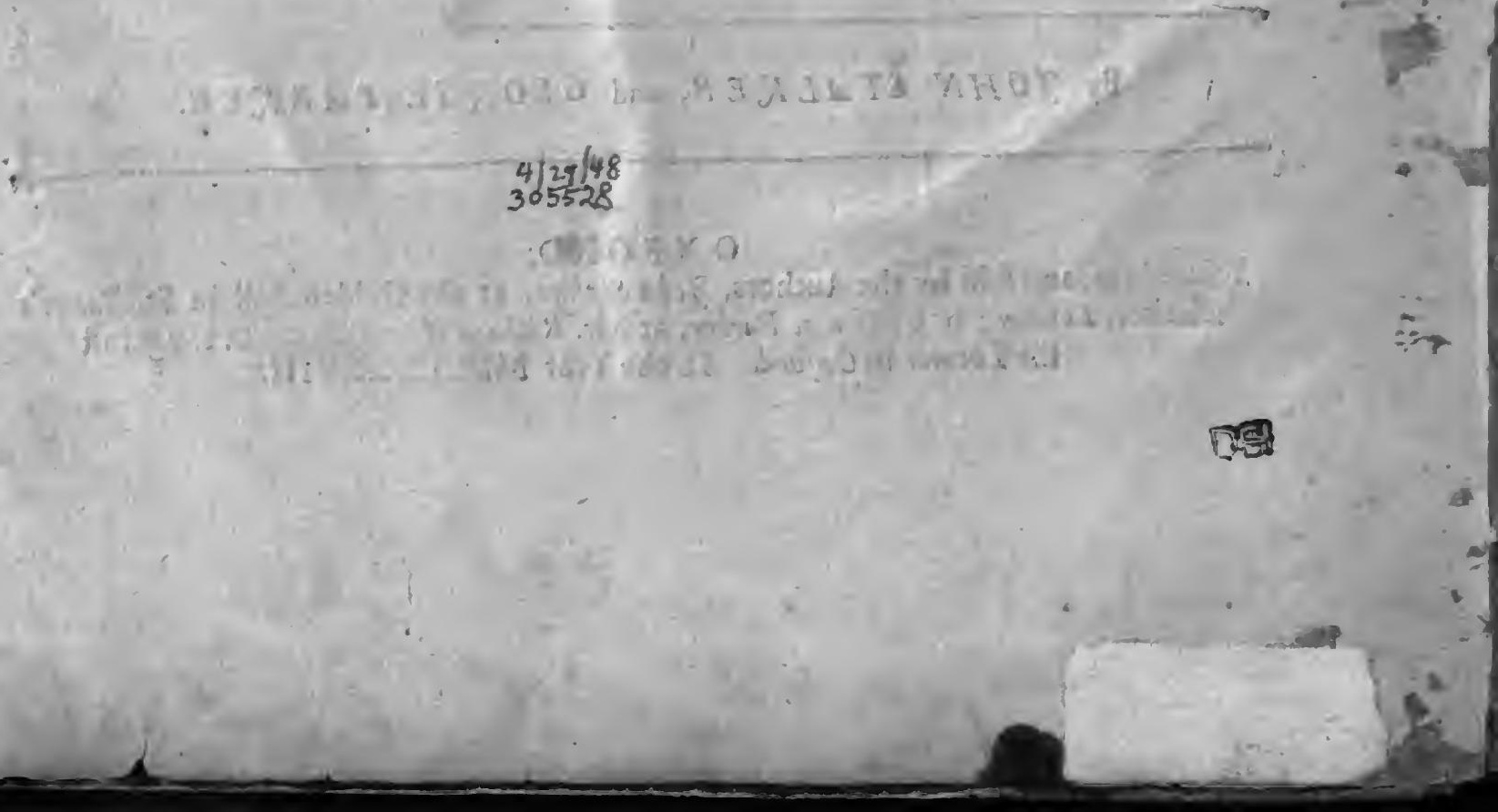




\section{THE PREFA CE}

\section{To the eAdmirers of the Noble Arts of $\mathrm{PAIN}$ I I G, JAPAN ING, GUILDING, GC.}

$I^{\mathrm{F}}$

the Antiquity of an Art can advance its credit and reputation, 4 this of the Pencil may juftly claim it; for although we cannot trace it from its Original, yet we find many valuable Pieces extant in time of Alexander the Great. The Grecians (who always encouraged Learning and Ingenuity) had fo great an honoun for this Art, that they ordained, That Gentlemens Sons and Frecborn fhould be firft fent to a Painting-School, to learn the way to Paint and Draw Pictures, before they were inftructed in any other thing; Slaves and vulgar hands, by a perpetual Edict, were excluded. from the benefit and practice of it: And laftly, it was enacted, That the Art it felf thould be ranged in the firft degree of Liberal Sciences: After them the Romans entertain'd it with great refpect and veneration; and the Jews, though denied this Profeffion by their Law; were not wholly deftitute of Artifts; for St. Luke (if Tradition may be credited) was a Painter, as well as Evangelift and Phyfi. tian, and for that reafon we honour and refpect him as our Patron and Protector.

The Civilized of all Ages have given it a kind and moft obliging reception: Candaules King of Lydia purchiafed a Table, whereon the Battel of Magnetes was painted with excellent skill, for its weight in Gold; and King Demetrius, forbore taking the City of $\mathrm{R}$ hodes, left in the fire and plunder of his fouldiers he fhould have loft a Picture, which he prized beyond the Conqueft of the Tovvn. Indeed, they are fo highly valued by us, that vve think them fit ornaments for our Churches and Altars. The Hollanders reckon their Eftates and Worth by their pieces of Painting, and Pictures vvith them are ready and current money : in thefe ton they difcover theiringenuity, for you hall rarely meet vivith a better joke, than in a Picture. Some femals have alfo been well pleafed with this Art, which they imagin can heighten and preferve their beauties; Jezebels, who prefer Art to Nature, and a fordid Fucus to a native complexion; and tis fo familiar to meet with thefe walking $\mathrm{Pi}$ ctures, that unlefs we are very circumfject, we may be impofed upon with Ixion's fallacy, who embraced a Painted vapour for a Goddefs: Painting will certainly make us furvive our felves, and render the fhadow more lafting than the fubftance, when the colours are laid in the right place, and by the Painters hand.

Begging the Mufes pardon, I hould prefer a Picture to a Poem; for the latter is narrow and fhort-liv'd; calculated to the Meridian of two or three Countries, and perhaps as many Ages; but Painting is drawn in a character intelligible to all Mankiud, and ftands. not in need of a Glo1s, or Commentator, tis an unchangeable and. 


\section{The Preface.}

univerfal language. Painting can decipher thofe myftical characters of our Faces, which carry in them the Motto's of our Souls, whereby our very Natures are made legible. This comely pare is the Limners more peculiar Province ; and if the beauty and proportion of it can excite our love and admiration, what regard and efteem muft we referve for him, who can fo cxcellently defcribe both. The Rarities of this Art were never yet fo common, as to make them defpicable; for the world very feldom produced above one famous Artifan at a time; this Age brought forth a Zeuxis, that an Apelles, and the third an Angelo, as if a particular fprightly Genius was required, and they were to rife from the Phænix-afles of each other, or that Men were to be born Painters as well as Poets.

If we duly weigh the merits of the Pencil, we fhall find the deference and refpect which our Predeceffors paid to the Mafters of it, was moft juft and reafonable; and that we our felves ought not to. be wanting in gratitude and addrefs. By the Painters affiftance, we enjoy our abfent friends, and behold our deceafed Anceftors face to face: $\mathrm{He}$ it is, that ftretches out our Eighty to eight Hundred years, and equals our Age to that of our Forefathers. The Egyptian Pyramids and embalming Spices of Arabia, were not fufficient to refcue the Carcafs from corruption or decay; and 'twas a grand miftake, to fuppofe the Afhes of one body could be preferved by the duft of another: Painting only is able to keep us in our Youth and perfection; That Magick Art, more powerful than Medæa's charms, not only renews old age, but happily prevents grey hairs and wrinkles; and fometimes too; 11ke Orpheus for Euridice,forces the fhades to a furrender, and pleads exemption from the Grave. Mahomet's is truly the Painter's Paradife, for he alone can oblige with a Miftrefs for ever young and blooming, and a perpetual Spring is no where to be found but in his Landskip. In fine, what were the Heathen Gods but fancies of the Painter, all their Deities were his handywork, and Jove himfelf ftole his boafted Immortality from him.

Well then, as Painting has made an honourable provifion for our Bodies, fo Japanning has taught us a method, no way inferior to it, for the fplendor and prefervation of our Furniture and Houfes. Thefe Buildings, like our Bodies, continually tending to ruin and diffolution, are ftill in want of frefh fupplies and reparations: On the ane hand they are affaulted with unexpected mifchances, on the other with the injuries of time and weather; but the Art of Japanning has made them almoft impregnable againft both: no damp air, no mouldring worm, or corroding time, can poffibly deface it; and, which is much more wonderful, although its ingredients, the Gums, are in their own nature inflammable, yet this moft vigorouny refifts the fire, and is it felf found to be incombuftible. True, genuine Japan, like the Salamander, lives in the flames, and ftands unalterable, when the wood which was imprifon'd in it, is utterly confumed. Juft fo the Asbefton of the Ancients, the cloath in which 


\section{The Treface.}

which they wrapped the dead bodies, lay unchanged and entire on the Funeral Pile, and preferved the body, when reduced to afhes; from being mixt with common, and undiftinguifht duft. Not that tis only ftrong and durable, but delightful and ornamental. beyond expreffion: What can be more furprizing, than to have ous Chambers overlaid with Varnifh more gloffy and reflecting than polifht Marble? No amorous Nymph need entertain a Dialogue with her Glafs, or Narciffus retire to a Fountain to furvey his charming countenance, when the whole houfe is ane entire Speculum. To this we fubjoin the Golden Draught, with which Japan is fo exquifitely adorned, than which nothing can be mofe beautiful, more rich, or Majeftick: Let not the Europeans any longer flatter themfelves with the empty notions of having furpaffed all the world befide in ftately Palaces, coftly Temples, and fumptuous Fabricks; Ancient and modern Rome muft now give place. The glory of one Country, Japan alone, has exceeded in beauty and magnificence all the pride of the Vatican at this time, and the Pantheon heretofore; this laft, as Hiftory informs us, ivas overlaid. with pure Gold, and twas but proper and uniform to cloth the Gods and their Temples with the fame metal. Is this fo ftrange and remarkable? Japan can pleafe you with a more noble profpect, not only whole Towns, but Cities too are there adorned with as rich a Covering; fo bright and radiant are their: Buildings, that when the Suin darts forth his luftre upon their Golder roofs, they enjoy a double day by the refeation af iils beams. Thefe delights would make us call to mind the fictions of the Poets, and perfwade us that the Golden Age was ftill in being, or that Midas his Wifh had at length fuceded: 'Surely this Province was Nature's Darling, and the Favourite of the Gods, for Jupiter has vouchfaft it a Vifit, as formerly to Danae, in a Golden flower: 


\section{READER and PRACTITIONER.}

VV

E have laid before you an Art very much admired by us, and all thofe who hold any commerce with the Inhabitants of $\mathcal{F} A \dot{P} A N$; but that Ifland not being able to furnib the e e parts with work of this kind, the Englifh and Frenchmen bave evideavoured to imitate them; that by the fe means the Nobility and Gentry might be compleatly furnilbt with whole Setts of Fapan-work, whereas otherwife they were forc't to content them felves with per. haps a Streen, a Drefing-box, or Drinking-bowl, or forse-odd thing that had not a fellow to anFwer it: but now you may be ftocks with entive Furniture, Tables, Stands, Bojes, and Looking-glas-frames, of one make and dejgen, or what fafbion you pleafe; and if done by able Hasds, it may come. To near the trike Fapan, in fineness of Black, and neat ne's of Draught, that no one but an Artist bould be able to diftinguifb' $\mathrm{em}$. Tis certain, that not only here, but in 7AP AN too, there is a vaft difference in work: we our felves bave. Seen fome that has been brought from thence, as mean andordinary in Draught, (though tbe ground-work may be pretiy good,) as you can polsbly imagine. As. for our Undert akers in this kind they are very numerous, and their works aredifferent; Some of them bave more confidence than skill and ingenuity, and without modesty or a blufb impofe upon the Gentry Juch Siuff and Trafb, for Fapan-work, that whether tis a greater fcandal to the Name or Artificer, I cannot dctermin. Might we advife such foolifb pretenders, their time would be better imployed in dawbing Whifles and Puppets for the Toy-Shops to please Children, than contriving Ornaments for. a Room of State. "Twill certaisly pleafe us to bear fuch Ignorants blame this our Publication of an Art, that was not underftood by the world: tis unknown, the confels, even to them, and they them felves will find "pon examination, that we bave difcovered miore than they ever knew or dreamt of, and in fpite of all their Bravado's, will be bcholding to our Rules and Patterns: Theje Pages are fo far from expofing our Art, that nn the contrary it enhances arid raifes its efreem and value. Thefe

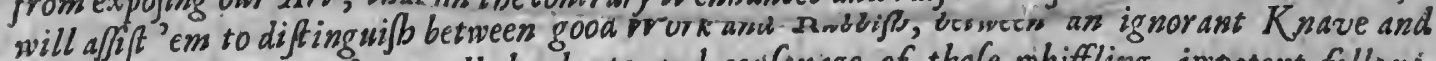
an Artift, and put a ftop to all the cheats and coufenage of thole whiffling, impotent fellows, who pretend to teach young Ladies that Art, in which they them (elves have need to be inftructed, and to the difgrace of the Title lurk and Jelter themfelves under the notion of Japanners, Painters, Guilders, $\delta c$.

What we have delivered in this Treatife, we took not upon Truft or Hear lay, but by our own per: Sonal knowledge and experience do promife and aver, that if you punctually obferve them, you muft of meceflity fucceed well; and if any Gentlemen or Ladies, baving met with difappointments in Some of the Receipts, do queftion the truth and reality of them, they may for their (atisfaction (if it ftands with their convenience) (ee them tried by the Author, according to the very Rules fet down; who is in this, and allother Commands, their moft ready and moft bumble Servant.

In the Cutts or Patterns at the end of the Book, we have exactly imitated their Buildings, Towers and Steeples, Figures, Rocks, and the like, according to the Patterns which the beft work. men amongft them have afforded us on their Cabinets, Screens, Boxes, \&c. Perhaps we bave belpt them a little in their proportions, where they were lame or defective, and made them more pleafant, yet altogether as Antick. Had we induftrioufly contriv'd prol pective, or fbadow'd them otherwife than they are; we bould have wandred from our Defign, whicb is osly to imitate the true genuine Indian work, and perhaps in a great meafure might puzele and confound the unexperienced Practitioner.

We know nothing farther that wants an Apology or Explariation; but to the fe our Endewrours do Subjoin our hearty Wibes for your bappy Progrefs axd Swccess, and Subfcribe,

rOVRS. 


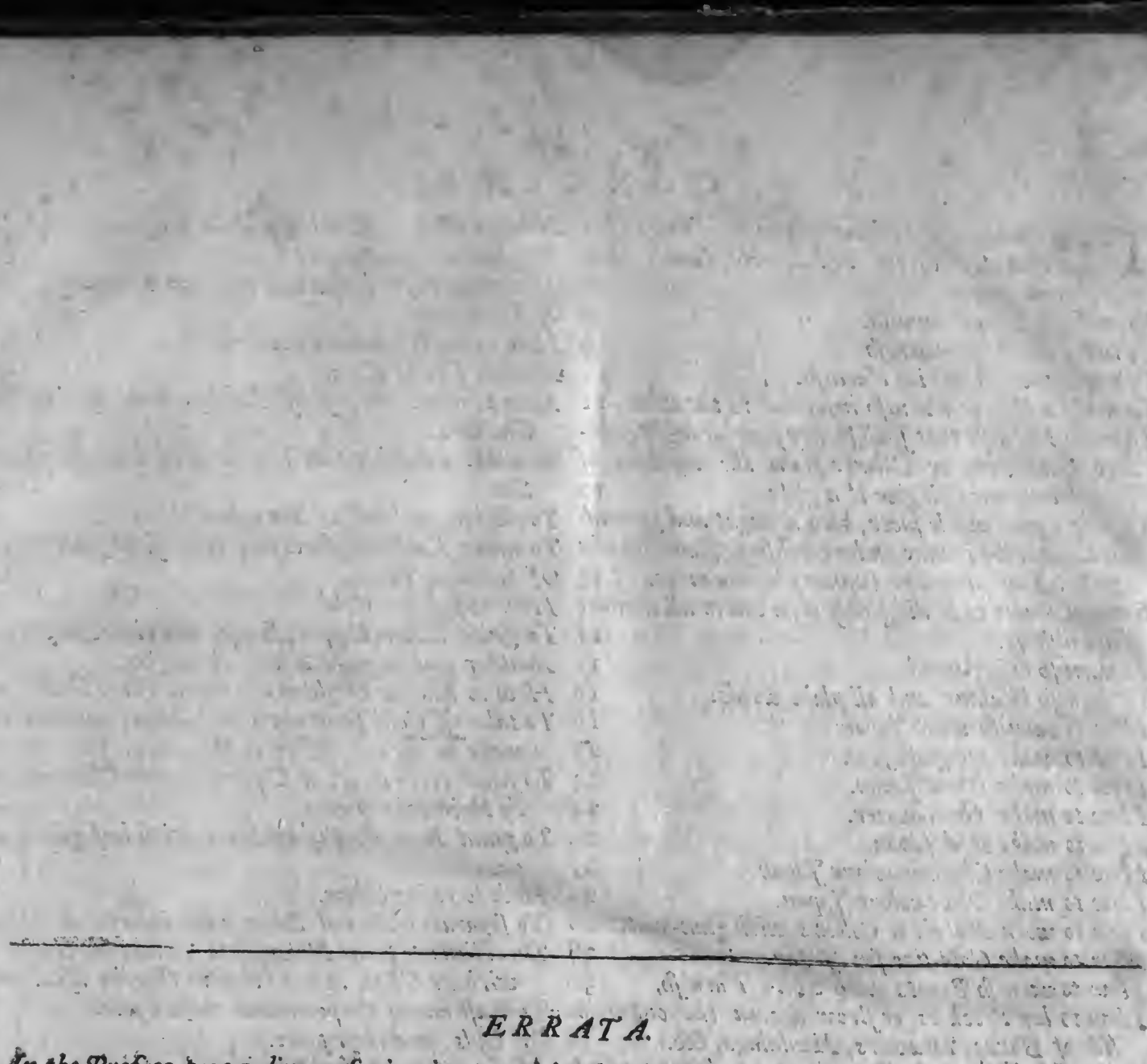

In the Preface, page 1 . line 4 for in time, read, in the time. 2.20 . for Magnetes, read, the Magnetes 1.28. for, better joke, read, better Dutch joke 2. alt. tis unchangeable; read, for tis unchangea.

In the Book, Page s. line 26. for, filver, read, filver-duft. p. 7.2 .25$. for Smalt, read Lake $l_{4} .4$ for Sea-green, read fine Smalt, and for, Greens, read, Blews. $p .25: l_{3}$ i. for, Miiller or: read Muller and p. 29. . 47. for, Venice Turpentine, read, oyl of Tuitpentine. l. ult. for Tur. pentine, read, Turpentine-oyl p. 36. after line the 27. read CHAP. XIIT p.6. 1. 0. for, narrow, read, many $P$ 77. l. I6. for red, r.brown-red. 6.16 . after vaxmilion, read, or.

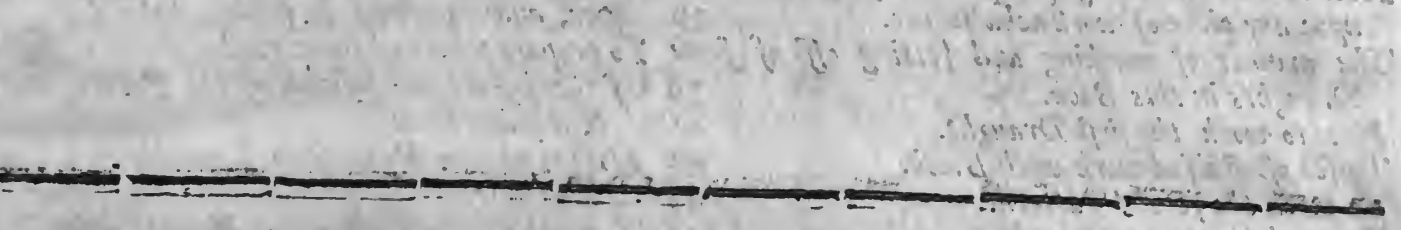




\section{O N T E N T S.}

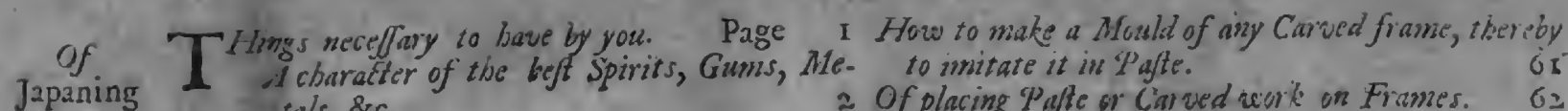
tals, \&cc.

To make Seed-lacc-qarwifh.

To make Sisell-lacc-varnifb.

2 Of placing Pafle or Carved work on Frames.

8 Of Lackerny

9 How 10 make comion lacker.

To make the beft White Varnifls.

Io Anstber fort of Lacker.

To make a White Varnifh inferiour to the otber. 1 I How so make the beft of Lacker now itfed by the To mis Varnifh that flall fecure your draught, whe.

Guilders.

ther Coldwork, or Colours, from the injuries of To make a Lacker that may be afed wootbout fire or

Tarsifking, and will give it a glofs. I2 Sun.

To fecure your wobole piece, both dranght and ground- To lacker on Oyl, or Burniped Silver.

wirk, wobeby it may endure polifhing, and obtain To make Lacker ing hew like Burnifised gold of a gla's all over like the Indian performances. 13 of Guilding Metals.

General Rules to be diligently obferved in all monner Howe to prepare Gold. 65

of varnibing. I4 To guild Silver, Copper, Brafs, or Princes metal.65

To zarnifh Olive-reod.

To canifh Walnut, and all plain woods.

How to varnifs black Fapan

How to make IJinglajs:-/ize.

How to make Blew Japan.

Hures to make Gum-water.

How to make Red Fapan.

Hoit to make Chefinut-colour Gapan.

How to make Olive-colour Zapan.

18 Anotber way to guild Silver, Brafs, \&cc. 66

18 How to beal or heighten the colour of the Gold. 66

19 To take off Gold from any Guilt Plate, withowit da-

22 mate to the one, or lojs to the ot ber. 60

23 To fliver over Brafs or Copper, as the Clock-maker's

24 do their Dial-plates. 66

24. To guild Iron, Brafs, or Steel with leaf-gold or. Fil

25 ver.

26 How to refine Silver.

How to work Metals or Colouts with gum-water. 26 To Separase Gold and Silver wben incorporated. 67

How to make Gold.jize for Yapan. 28 Directions to paint Mezzotinto Prints on GlaSs, or

How to varnifh Prints with white Varnifh. $\quad 30$ without Glafs, and the colours therein ufed. 69

How to lay Speckles, or ftrowings, on the out or in- Ta wafb any of the powdered colours fine. $\quad 7 \mathrm{~L}$

side of Boxes, Draweers, Mouldings, \&c. 31 Of Oyls, and ibeir price. . . 72

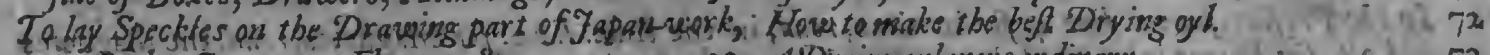
as Rocks, Ger ments, Flowers, \&c.

How to make Raifed work in imitateon of Japan, To make Varnifbes for theje prints or pigtures in

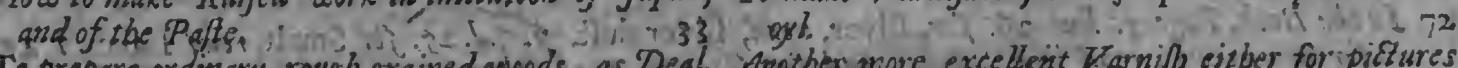

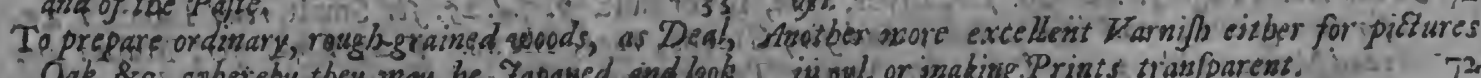

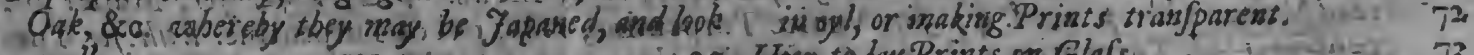

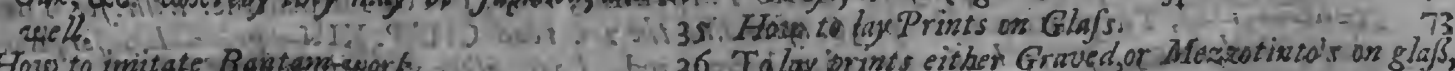

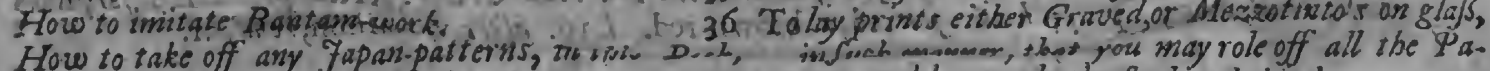
How to per, and leave only the padow behind. The manner of working and fetting off of some Toprepare prints, witbout glaßcr ftraining frames73 Draughts in this Book. 39 Of the pofture and pofition of the Prints, and thoje How to work the firft Draught.

To fet of Raifed work with Black. $4 \mathrm{I}$ that paint them. 74

To weork the lecond Fattern. 4.2 How to paint a Mezzotinto Landskip on a Glafs, or

To work the third Drangbt.
How to work in Colow's and Gold the great Sprig in How to paint Hair. the I 3 th Print.

To zeork in gold. Jue the 20 th Print of this Book. 4 How to paint changeable Diapery.

To work in gold-size the 23 d Draught of this Book To paint feveral forts of Red Drapery, and firft of

with perfect, and corrupt metals.
To guild any thing in Oyl, whereby it may Safely be Another Red near the fame.

$\begin{array}{ll}53 & \text { Oxher Reds more ordinary without glazing. } \\ 54 & 77\end{array}$

Guilding. How tomake Primer. $\quad$ s3 Ther.

of Fat oyl.

of Gold-fize in oyl.

How to mix and lay on Gold-fize.

s5 Purple without glazing.

Of the laying on the Gold, and the Tools reguired in, Tellow Drapery.

and for the bujine Js.

55 How to paint the moft beantifus rellow. 78

To lacker in oyl, fuch things as are to be exposed to To finifh, yarnifh, and polifh pictures that are not laid the weather. 56 on glafs.

To prepare and guild Carved Frames in cyl, that To vurnifh ibefe prints, or utber pictures withont poare not to be expofed abroad.

"of To cverlay wood with Burnilbt gold, or filver.

of Gold and Silver-fize for burniging.

Burnifh- The beft wiay to make Silver-fize.

ing. The beft Gold-lize now in use.

Anotber Size for Silver.

How to gold-jize your Frame.

How to lay on Gold for Burnifing.

How to burnijh your work.

How to lay on Siluer-fize. s6 lifbung.

How to make Pafte, fit to mould or raife $C$ arvo work on Frames for Guilding,

Hozo to make Pafts.

s7 To varnig picture s,and polifh them like Japan.

57 To imitate or counterfeit Tortoile-joill.

s 8 Anotber way to connterfitit Tortorle-gell.

s8 How to Dye Wood a beautifisl Red.

58 How 10 Rtain a fine Tellow.

82

59 'To ftuin or dye woods of any colour for inlaied or flawe-

s9 red work done by the Cabine-makers. $\quad 8_{3}$.

60 Hare to dye or finin wood Black. 83 6o The beft Black'Dye for I wing, Horn, Bonse, \&c. $8_{3}$ ved To ftain a oreen colour wis Wigd, Irary, Horn. or

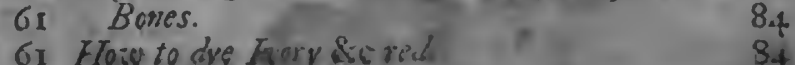




\section{JAP ANNING, VAR NISHING, oc,}

H. Very Artift, who undertakes to treat of his Profeffion, before

1. he enters on the work, muft defcribe the Inftruments and $\mathrm{Ma}$ terials with which it muft be performed: and by obferving this method, thofe perfons who either for diverfion or advantage defign to be Mafters of this Art, furnifh themfelves with all things neceffary after the beft manner, fhall lay a good foundation, and may proceed to practife with chearfulnefs and fuccefs. And that no one may impofe upon you in the Price or Goodnefs of your Drugs; that your Spirits be very ftrong, your Gums and Metals of the beft; take this following account, as your only fecurity againft all coufenage and impofture. But before I fpeak of thefe things which the Shops fupply us with, I prefume tis convenient to acquaint you with others, that conduce to the compofition, mixture, and prefervation of the Varnifh, Colours, \&c.

And I. two Strainers are required, made of pretty fine Flannel or ordinary courfe Linnen, in thape like a Tunnel, or Sugar-loaf, or a Jelly-bag that women ftrain Jellies through :s one is ufeful for fraining your white Varnifh, and the other for your I.acc-varnifh, and Lackers, when vou make any.

2. You muft have two Tin-tunnels; one to ufe with your Laccvarnifh, and Lacker, and the other for your white varnifh for the fame ufe.

3. You muft be furnifhed with feveral Glafs bottles, and Vials fimall and great, according to the quantities of varnifh you make or. ufe; and alfo with Gally-pots of feveral fizes, to put your varnilh in when you intend to varnifh: and for your Blacks, with which other things muft fometimes be mixed, Gally-pots are better than any other veffels to mix your blacks and hold your varnifh, becaufe they are deeper than Pottingers, and not fo wide, fo that the varnifh doth not fo foon thicken, for the Spirits in a deep Gally-pot do not fo fuddenly evaporate.

4. You hould provide feveral forts of varnifhing-tools, or Pencils, according to the greatnefs or fmalnefs of the thing you defign to work. Your varnifhing Pencils are foft, and made of Camels hair, and are of feveral prices, according to the bignefs, of them : the beft that I know are fold in Blackamoor-ftreet by Clare-market, but you may have them alfo at fevenal Colour-fellers in and about London, from fix-pence to half a Crown or three fhillings the Pencil.

5. You muft procure Pencils to draw with, friall and greater, Goofe, little Goofe, Duck, and Swallow-quills, according to your, 
work. The longeft haired Pencils I efteem the beft for this ufe; you may have them all at the places aforefaid.

6. You fhould get 200 of Mufle-fhells, that you may have them always in readinefs to mix your Metals or Colours in, as occaficn fhall ferve: not that you need ufe the tenth part of them at once, but that you may not be to feek when you want; and for change, when your metals or colours, by frequent mixture, fhall grow dirty, which will be, if you work in Gum-water, as I thall hëreafter obferve.

7.: You thould furnifl your felf with Ruflies, which are called Dutch-Rufhes, with which you muft finooth youri work before you varnifh it; and as you lay your ground of Colour or Black, if any knob or roughnefs appear on lyour work'; you muift take' a Rüfh and rufh it off; fo muft you:do as oft as you find any roughnefs or grittinefs upon your work, either in laying your Grounds, or varnifhing it up. You may buy them at the Iron-mongers.

8. You muft have Tripoly to polifl your work after it is varnifted, which muit be feraped, or finely pounded and fifted. But of this I thall have occafion to fpeak more largelys, when I coine to give rules for varnifhing you may have it at the Iron-mongers.

9. You cant be without ftore of Linnen-rags as well coarfe as fine, with which you muft polifh and clear u.p your work, as fhall be fhewed hereafter

Io. You muft have Sallet-oyl for clearing up your work, as fhall be notified in its proper place. All thefe things every Practitioner ought to provide, as boing nereffariv to his fitrire performances.

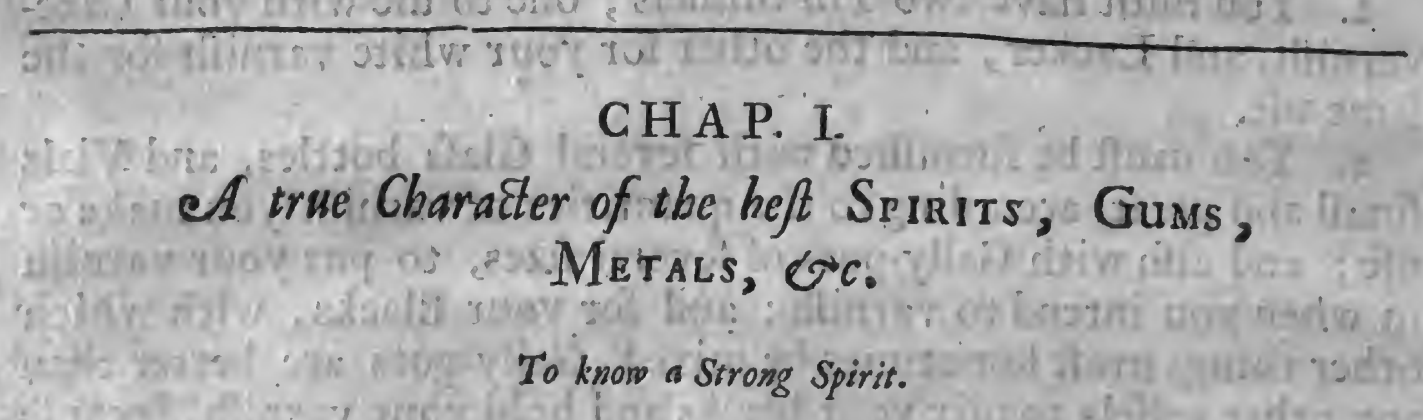

TPO make Varnifh you muft have Spirit of Wine, which inuft 1 be ftrong, or it will fpoyl the Varnifh, and not diffolve your Gums, and confequently hinder your defign; for the ftronger your Spirits are, the better will the Varnifh be; the Spirits only being to diffolve the Gums, in order to make them fpread, or lie even upon the work. After it hath performed that work, the fooner they evaporate the better, and the higher the Spirits are drawn, the lefs flegin or watery parts are in them; and the lefs of watery parts are in the Varnifh, the fooner it dries, and is fit for polifhing, is more permanent, and will come to the greater and better glofs. But this is of little ufe now Varnifh is fo much ufed; for the Diftillers have learned by practice and cuftom to make Spirits that juft diffolve the gums, only it requires the longer drying: Yet thefe Spirits that 
- The Art of Japaning, Varnibing, \&c.

are commonly ufed will fometimes be too weak, either by neglect or difhonefty of the Diftiller, who hath not fufficiently deflegin'd or drawn all the watery from the fpirituous parts i Therefore the beft way to prove your Spirits, is to take fome in a fpoon, and put a little Gun-powder in it, and then fet the Spirit on fire with a little paper or candle, as you do Brandy, and if it burn fo long till it fire the Gunpowder before it go out, it is fit for ufe, and will diffolve your Gums. All pretenders to this Art know this way of trying Spirits, and the damage weak Spirits do the Varnith : but fince iny defign is to inform the ignorant and learner, it is reafonable and neceffary in this place to infert it.

To choofe Gum Lac, called Seed-Lac.

The beft Seed-Lacc is that which is large-grained, bright, and clear, freeft from duft, fticks, and drofs. The Drigfters afford it at feveral rates, proportionable to its goodnefs, generally for 14 . I 6 . I8d. the pound.

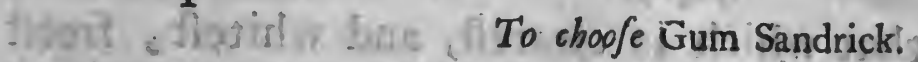

The beft Gum-Sandrick is the largeft and whiteft, or that which cafts the leaft yellow. Let it be as free from duft or drofs as you can. The value of it is commonly $x i$ or $x 4$ d. the pound.

\section{To choofe Gum Animæ.}

The whiteft, cleareft, and moft tranfparent is the beft, and the price is fometimes $3 ; 4$; or 5 s. the pound, according to the goodnefs.

$$
\text { Venice-Turpentine. }
$$

The only directions that can be given for the choice of it are, that the cleareft, fineft, and whiteft is the beft; and is fold at 18 or $20 \mathrm{~d}$. the pound.

The beft white Rofine is white and clear, and purchafed at $4 \mathrm{~d}$. or 6 d. the pound.

The beft Shell-Lace is the moft tranfparent, and thinneft, and that which(if melted with a candle) will draw out in the longeft and fineft hair (like melted wax) becaufe the tougheft. There are counter feits, which you muft endeavour to difcover by the aforementioned rule. The true may be procured at $18 \mathrm{~d}$. or 2 . the pound.

The beft Bole Armoniak is as fine as red Oker, and of a deep dark, blackifh-red colour, free from grittinefs or gravel, and is commionly
called French-Bole.

\section{Gum Arabick.}

The beft is clear, tranfparent, and white: you may pick it your felf from the Drugfters, but then you muft pay fomething more; the common rate is $\mathrm{I} 2 \mathrm{~d}$. the pound.

$$
\text { C } 2
$$


The beft Capall is the whiteft, freeft from drofs, and thick dark fuff that is incorporated with the Gum. It is of it felf a thick whitifh heavy Gum, and rarely without that dark and droffy mixture; but that which is cleareft and freeft from the faid ftuff is the beft. The price is 12,16 , or $18 \mathrm{~d}$. the pound, according to the goodnefs.

\section{To choofe Gum Elemni.}

The beft Gum Elemini is the hardeft, whiteft, and cleareft, freeft from drofs or dirt. It is brought over commonly in the bark or husk of a Tree; which you may take off as well as you can before you ufe it. The Shops can afford it at 4 or $5 \mathrm{~d}$. the ounce.

$$
\text { Rofine. }
$$

The beft is the clear, and tranfparent, and clarified. It may be had at $3 \mathrm{~d}$. the pound.

$$
\text { Ifinglafs. }
$$

The beft Ifinglafs is that which is cleareft, and whiteft, freeft from yellownefs. It is, if good, worth 3 or $4 \mathrm{~d}$. the ounce; you may have it cheaper by the pound. The fame may be obferved by other things; for the greater quantity you buy at a time, the cheaper will your purchafe be.

The beft is that of the brighteit yellow, and freeft from drofs. Some of it is dirty, thick, and full of drofs: there is difference in

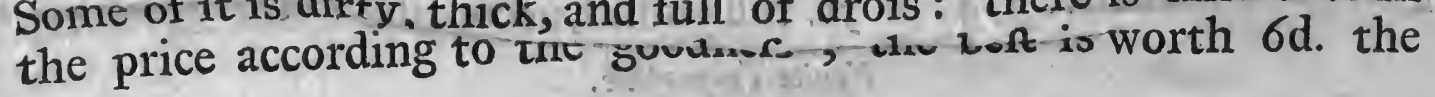
ounce.

To choofe Benjamin, or Benzoine.

- The beft is that of a bright reddifh colour, very like to clarified Rofine, but never fo fine, freeft from drofs or filth. Tis as in goodnefs, $4 \mathrm{~d}, 6 \mathrm{~d}$, or $8 \mathrm{~d}$, the ounce.

\section{Dragons Blood.}

The beft is the brighteft red, and freeft from drofs. You may buy it in drops (as the Drugfters call it) which is the beft. They are made up in a kind of leaf or husk : it is commonly $8 \mathrm{~d}$. fometimes $12 \mathrm{~d}$. the ounce, according to the goodnefs.

I have here given you an account of thofe things and Gums you will have occation for in Japanning and Varnifhing, and are all to be bought at the Drugfters at or neer the prizes I have fpecified; and may ferve to inform you in fome meafure of the Gums, their excellencies and value, but time and practice will make greater difcoveries. Indeed grains of Allowance muft be made for their different prizes; for their rife and fall depends upon the plenty or fcarcity of them, and varies according to the goodnefs of the commodity. It is not neceffary to furnifh your felf with all, or any part of thefe, but as you have occafion to make ufe of them : for of fome, 
The Art of Japanning, Varnißhing, \&c.

fome an ounce will ferve you a great while, of others a pound will be ufed at one time; of which you will know more, as I thall have occafion to treat of them in their order. I thall now proceed to Metals, which I will alfo give you fome account of; and firt,

Of Brafs-duft, which is commonly amongft the Artists called Gold-durt:

This cannot be made in England fit for úfe, though it hath often been attempted, but comes from beyond Sea, as the reft of the Metals do that are good. Germany is the place where the beft of all forts is made. The beft Brafs-duft is that which is fineft, and of the brighteft and moft gold-like colour; which you may beft difcern, by taking a little on your finger, and fqueezing it along your finger with your thumb; and if it be good, it will look with a bright and rich luftre, if bad, it will appear of a dull clayifh colour, and will never work lively and bright Several forts of this $\mathrm{Me}$ tal are imported here from foreign parts; which differ vaftly as to the coarfnefs and finenefs, and the different ways of working them: As for inftance, the coarfer fort will work well with Gold-fize, which will not with Gum-water; other differences will arife alfo, which are fubject to the difcoveries of practice and experience. From this difference of Metals proceeds that of the prizes; for fome are worth 12 or I4S. the ounce, whilft that others amount to not above 4 or 5 . for the fame quantity. But thefe are two extremes; the firft very good, and the other al together as vile and bad; for there is a middle fort between both, which is generally

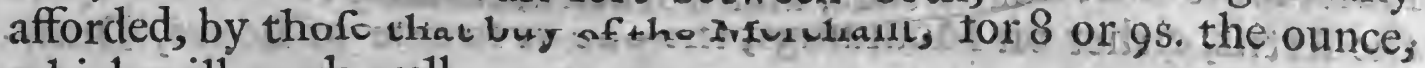
which will work well.

\section{To choose Silver-duft.}

Some have attempted to make Silver here in England, but none I ever faw comparable to that beyond Sea; for that enjoys a lively bright luftre like polifhed or new-coined filver, (which you may find by fqueezing it between your finger and thumb) whereas that which we make here is dull, dead, and heavy, and indeed is a fitfer reprefentation of a Colour than a Metal; and by comparifon you may find; how the dimners of the counterfeit is obfcured by the dazling luftre of the true. Its price is anfwerable to its goodnefs and excellency; for its loweft rate is no lefs than I6s: the ounce: But I would not have the price fright any one fo far, as to prefer cheaper before it, for tis neither fo ufeful nor pleafant in the work, and the beft will go farther than this proportionable to its price Tis cuftomary in Japan to ufe feveral forts of Metals that are corrupted and adulterate, and they are layed too in garments, flowers, houfes, and the like, which makes the work look more beautiful and furprizing : thefe likewife are vended and fold for the aforefaid ufe and are commonly called;

$$
\text { Firft, Green-gold, }
$$

Is a certain corrupted mettle, cafting a kind of a dead greenilh colour, and is commonly fold at 6 s: the ounce. 
The Art of Japanning, Varnifhing, \&c.

\section{Dirty-Gold}

Is another kind of corrupted metal, which bears fome refentblance to drofly dirty Gold : it may be purchafed at 6 s. the ounce.

\section{Powder-Tinn}

Is Tinn grinded to duft, of a dull, dark, though filverifh colour; made ufe of in Rocks, \&c. Its price the fame with the former.

$$
\text { of Coppers }
$$

There are three forts, Natural, Artificial, and Adulterate.

The Natural is ground without mixture, well cleanfed, and is of the trie genuine colour of Copper, and is fold at 6 or 75 . the ounce.

The Artificial accordingly exceeds the Natural; it is more deep and red, but very clear, and its bright glittering colour thews how far it is poffible for Art to exceed Nature. Tis very rarely procured, or fold under ros. the ounce.

The Adulterate Copper is of a thick, heavy, metallick colour, and is commonly ufed to work other metals on, as if that be layed for a Ground, you hatch or highten with bright gold, or other light metal; and fold at 6 s. the ounce.

There is alfo ufed in Japan-work metals, commonly called Speckles, of divers forts, as Gold, Silver, Copper, and many other colours, fome finer than other, and worked according to the fancy of the Artift, either on Mouzanys, inw ont as in-fide of Boxes, Drawers, \&cc.

Of thefe, thofe that are ufed in the Indian work, are the Gold, Silver, and Copper, though, as aforefaid, every one may take their own fancy or humor in the ufe of them.: They are made here in England very well, and are fold each of them much at a price, 5 or 6 fhillings the ounce, according as they are in finenefs. So that what I faid concerning the rates of Gums, will hold good here alfo, That a glut or fcarcity of thefe enhances or abates the price; but generally thefe are expofed to fale at the rates I have affixed to each of them. Thefe are fold by great quantities by feveral Merchants in London; and in leffer, by as many. I thall only mention two, viz. a Gold-beater, at the hand and hammer in Long-acre ; and another of the fame trade, over againft Mercers-Chappel in Cheapfide.

Having given you an account of Gums, and Metals, I thall briefly run over the Colours, which formerly our ignorant Englifh and French Practitioners ufed to mix with their Japan-work, but improperly; for the true natural Japan-work, fo called from the Inand of that name, did fo far furpafs all the painting of Bantam, and the neighbouring places, in goodnefs of black and ftatelinefs of draught, that no fidling pretender could match or imitate it ; and the ignorant undertaker not being able to make his work look well and lively, 
lively, inferts feveral colours as a file to fet it off, when (unfortus. nate man) inftead of art, fancy, and skill, he expofes a piece gay, queint, gawdy, finical, and mean, the genuine product of ignorance and prefumption; and an ornament of Bartholmew, or Alehoufe, rather than a Palace or Exchange. The miftake of Bantam-work for Japan, arofe from hence : all work of this kind was by a general name called Indian; by ufe they fo far confounded all together, that none but the skilful could rightly diftinguifh. This muft be alledged for the Bantam-work, that tis very pretty, and fone are more fond of it, and prefer it to the other, nay the work is equally difficult with Japan: But if I muft give you my opinion, my skill and fancy induce me to believe, that Japan is more rich, grave, and Majeftick, and for that reafon ought to be more highly efteemed. But fancy, like Proteus, putting on a thoufand hapes, cannot, ought not, be confined; and thofe who are inclined to admirc colours, may find fafe and exact rules fet down by way of information.

And firft, fome colours we call tranfparent; fuch as are thofe we lay upon Silver, Gold, or fome light colour, and then they appear in their proper colours very beautiful and lively. Of thefe for your ufe is, firft, Diftilled Verdigreece, for a green; fine Lake for a red; fine Smalt, for a blew. To render thefe ufeful, you muft obferve the following method : having provided a Porphyr, or Marble ftone, with a Muller, take what quantity of Verdigreece or Smalt you pleafe, and with Nut-oyl, fo much as will juft moiften it fit to work, grimd it upues yrax nuenc uil ic be as fine or finer than butter; then put them in fhells, mixing them with Turpentine oyl till they be thin enough for your ufe; lay thefe upon filver, gold, or any other light colour, and they will be tranfparent, and alter their lightnefs or darknefs according to the lightnefs or darknefs of the metals or colours you lay under them. The fame may you do with Lake for a red, only inftead of Nut-oyl, ufe Prying oyl to grind it in.

Other colours are ufed which have a body, and are layed on the black of your table or box, where you have defigned any thing, as Flowers, Birds, \&c. Thefe are Vermilion for a red, White-lead for a white; fome ufe Flake-white for, a white, which is a purer white, and much better, but for ordinary tork the other will do: if you make a blew to lay upon your work, you muft take Smalt, and mixing it with Gum Arabick-water put in what quantity of whitelead you pleafe, to make it deeper or lighter, as your fancy fhall direct; but you muft put in white-lead, becaufe your blew ivill not otherwife have a body; fo muft you do with all colours that have not a body of themfelves. Some ufe Rozett, fine Lake, and Sea-green, for a Purple, and other forts of Reds and Greens: and indeed ways of working are very numerous, which being now out of fafhion, I fhould to no purpofe both trouble you, and tire my felf, by increafing the number; thofe which I have mentioned are

$$
\text { C } 2
$$

abuils 
abundantly fufficient, for any that defign to have fomething befide gawdy colours in their work. Twill be convenient here to infert a. caution concerning thefe Colours; that they are all to be layed with Gum-water, except the tranfparent ones above-mentioned: and whofoever hath a mind to work, either in Gum-ivater, or Goldfize, thall hereafter receive fufficient Inftructions for both.

According to my promife $I$ have in full treated of Gums, Me. tals, and Colours; I thall now in full proceed to difcover the methods that are ufed to make Varnifhes.

\section{H A P. II. \\ How to make VARNISHES. \\ To make Seed-LacG-Varnif.}

TAke one gallon of good Spirit, and put it in as wide-mouthed a bottle as you can procure; for when you fhall afterwards Itrain your varnifh, the Gums in a narrow-mouthed bottle tnay ftick together, and clog the mouth, fo that it will be no eafie task to feparate or get them out. To your fpirits add one pound and a half of the beft Seed-lacc; let it. ftand the fpace of 24 hours, or longer, for the Gum will be the better diffolved : obferve to Thake it very well, and often, to keep the Gums from clogging or caking together. When it hath ftood its time, take another bottle of the fame bignefs, or is many ynatevino as will contain your varnifh ; and your ftrainer of flannel made as aforefaid in this book, faften it to a tenter-hook againft a wall, or fome other place convenient for ftraining it, in fuch a pofture, that the end of your ftrainer may almoft touch the bottom of your Tin-tunnel, which is fuppofed to be fixed in the mouth of your empty bottle, on purpofe to receive your ftrained varnifh. Then thake your varnifh well together, and pour or decant into your ftrainer as much as conveniently it will hold, only be fure to leave room for your hand, with which you muft fqueez out the varnifh; and when the bag by fo doing is almoft drawn dry, repeat it, till your ftrainer. be: ing almoft full of the dregs of the Gums, . Thall (the moifture being all preffed out) require to be difcharged of them: which feeces or dregs are of no ufe, unlefs it be to burn, or fire your chimny: This operation muft be continued, till all your varnifh is after this man ner ftrained; which done, commit it to your bottles clofe ftopt; and let it remain undifturbed for two or three days : then into an; other clean empty, bottle pour off very gently the top of your var: nifh, fo long as you perceive it to run very clear, and no longer; for as foon as you obferve it to come thick, and muddy, you muft by all means defift: and again, give it time to reft and fettle, which 'twill do in a day or two; after which time you may attempt to draw off more of your fine varnifh; and having fo done you may lay 
lay it up, till your art and work fhall call for its affiftance. Tis certain, that upon any emergency or urgent occafion yon may make varnifh in lefs time than 24 hours, and ufe it immediately, but the other I recommend as the beft and more commendable way: befides, the varnifh which you have from the top of the bottles firft pour'd off, is of extraordinary ufe to adorn your work, and render it gloffy and beautiful. Some Artifts, through haft or: inadvertency, fcruple not to ftrain their varnifh by fire or candlelight: but certainly day-light is much more proper, and lefs dangerous; for fhould your varnifh through negligence or chance take fire, value not that lofs, but rather thank your ftars that your felf and work-houfe have efcaped. Should I affirm, that the boiling the Lacker and Varnifh by the fire, were prejudicial to the things themfelves, I could eafily make good the affertion; for they are as well and better made without that dangerous element, which if any after this caution will undertake, they may feelingly affure themfelves that tis able to fpoil both the Experiment and Operator. On the other hand, no advantage or excellence can accrue either to Lacker or Varnifh ; efpecially when,as fome of them do, tis boiled to fo great a height, that this \& Ena is forc'd to throw out its fiery eruptions, which for certain confume the admiring Empedocles, who expires a foolifh and a negligent Martyr; and it would almoft excite ones pitty, to fee a forward ingenious undertaker, perifh thus in the beginning of his Enterprife; who might have juftly promifed to erect a noble and unimitable piece of Art, as a lafting monument of his fame and siumury: but (unhappy man) his beginning and his end are of the fame date; his hopes vanifh, and his mifchance thall be regiftred in doggrel Ballad, or be frightfully reprefented in a Puppet-fhew, or on a Sign-poft.

\section{To make Shell-Lacc-uarnifb.}

Whofoever defigns a neat, glofly piece of work, muft banifh this as unferviceable for, and inconfiftent with, the rarities of our Art: But becaufe tis commonly ufed by thofe that imploy themfelves in varnifhing ordinary woods, as Olive, Walnut, and the like; tis requifite that we give you directions for the compofition of $i t$, that if your conveniency or fancy lead that way, you may be fupplied with materials for the performance. Having therefore in readinefs one gallon of the beft Spirit, add to it one pound and a half of the beft Shell-Lacc. This mixture being well ftirred and thaked together, fhould ftand about twenty four hours before tis ftrained: You might have obferved, that the former varnifh had much fediment and dregs; this on the contrary has none, for it wholly diffolves, and is by confequence free from all drofs or fæces; tis requifite however to ftrain it, that the fticks and ftraws, which often are in the Gum, may by this percolation be feparated from the varnifh. But although this admits of no fediment, and in this cafe differs from the aforementioned varnifh, yet tis much inferior alfo to it in an- 
The Art of Fapanning, Varnilbing, \&c.

other refpect; That this will never be fine, clear, and tranfparent, and therefore 'twill be loft labour to endeavour, cither by art or induftry, to make it fo. This finall adyantage however doth arife, that you need not expect or tarry for the time of its perfection, for the fame minute that made it, made it fir for ufe. This, as I hinted before, is a fit varnifh for ordinary work that requires not a polifh; for though it inay be polithed, and look well for the prefent,'yet like a handfom Ladies beautiful face, it hath no fecurity againft the injuries of time for but a few days will reduce it to its native mift and dulnefs. Your common Varnifh-dawbers frequently ufe it, for tis doubly advantageous to them: having a greater body than the Seed-Lace, lefs labour and varnifl goes to the perfecting their work: which they carelenly flubber over, and if it looks tolerably bright tin tis fold, they matter not how dull it looks afterward; and lucre only being defigned, if they can compafs that, farewel credit and admiration. Poor infufficient Pretenders, not able to make their work inore apparent, or more lafting than their' knavery! And tis pretty to think, that the fame mifty cloak will not cover the fraud and the impoftor! that the firft thould be a foil to the fecond, and the dull foggy work ferve only to fet off the knavinh Artift in his moft lively colours! But to conclude, if with a pint of this varnifh you mix two ounces or more of Venice-turpentine, it will harden well, and be a varnifh good citough for the infide of Drawers, frames of Tables, Stan-pillars, frames of Chaite- ftools, or the like: Painters Lacker made alfo with this Varnifh, and lometming i larger quantity of Turpentine put to it, ferves very well for lackering of Coaches, Houfes, Signs, or the like, and will glofs with very little heat, and, if occafion be, without.

To make the best Wbite-uarnif.

I would defire the Reader to obferve, that when any Drugs, Guins, or Spirits, are fet down for the ufe and making of Varnifh, Lacker, or the like, though we do not to every particular write the beft of fuch a fort, yet that you fhould underftand our meaning to befich, when we do not particularly forbid the getting or buying of the beft; for tis irkfom and tedious to every fingle drug to affix the word Beft: wherefore to avoid fo needlefs a repetition, I thall forbear mentioning it above once, either at the beginning of end, as it thall feem moft neceffary. Befides, tis a very reatonable fuppofition; for you muft not expect to raife a Noble piece from drofs or rubbifh; to erect a Louvre or Efcurial with dirt or clay, nor from a common $\log$ to frame a Mercury. But to return to our defign of White-varnifh : Being furnifhed with one pound of the whiteft Gum Sandrick, one ounce of the whiteft Gum Maftick, of the cleareft Venice-Turpentine three ounces, one ounce and a half of Gum-Capal, of Gum-Elemni half an ounce, of Gum-Benzoin or Benjamin the cleareft half an ounce, one ounce and half of the cleareft Gum Anime, and of white Rofine half an ounce. The 
Gums thus feparately and in their due quantities provided, each being the beft and moft excellent in its kind; I muft defire you to obferve carefully the following order in their mixture and diffolution. Put the Capal and Rofine in a glafs-vial, with half a pint of Spirits to diffolve them : for the fame end to another glafs, contilining thice quarters of a pint of Spirits, confine the Gum Animo; Benjamin, and Venice-Turpentine. The, Gum Sandrick and Maftick fhould likewife enjoy the priviledg of a diftinct bottle, and in it a pint and half of Spirits, for their more effectual diffolution; and laftly, the Gum Elemni by it felf, content with one quarter of a pint of Spirits. to diffolve it. Tis not highly neceflary to obferve the quantities of Spirits fo exactly: but this in general $I$ advife, that all your Spirits exceed not three quarts. They muft in this diftinet manner be diffolved, the better to extract the whole virtue of each Gum, and prevent their clogging and caking together, which would much hinder their being quickly or throughly diffolved. I I muft not forget further to acquaint you, that the Gum Animze and Benjamin be very finely pounded and reduced to powder, before they are mixed with the Spirits; you may alfo bruife the Capal and Rofine, as for the reft, they may be ufed or put in to the. Spirit as you buy them, without any alteration. Having thus carefully mixt 'en, let them carefs one another for two or three days; and make them dance or change places, by thaking very briskly each bottle or vial once in two hours for the firft day; the remaining time flatke them at your own conveniency. Then take a bottle large and capacious enough to hold all the varnin you nave made, and through the fine linnen Strainer (of which in the beginning) ftrain all your gums, mixt as aforefaid; but fqueez gently, and not with fo clofe an hand as was required for your Seed-Lacc: for by this cafie percolation you prevent the fandy, hard, gritty ftuff paffing thiough into yous varnifh. Some never ftrain it, but with great diligence pour it off as long as twill run clear from each bottle. But if I may be a competent Judg, this is not fo good a way or fo convenicht, for thefe reafons: You have not, firft, fo much varnifh, neither can you pour it off fo clear and fine as you may by ftraining. Again, your dregs being left in, by frequent ufe will fill up your veflel, and the frefh Gums will mix with the old, and flacken the melting of them, all which our method difallows of ; and keeps the bottles empty, and fit for the fame repeated ufe, without thefe inconveniences. The varnifh thus ftrained having ftood three or four days, (the longer the better,) pour of gently as much as svill come very clear, referving the thick and muddy part at the bottom for ordinary ufes; as mixing with other varniff for black work, or to glofs the in-fide of boxes, as we thall hereafter more fully difcover.

To make a White-ruarnif much inferior to the former.

This is made out of two diftinct Varnithes, the one Sandrick, the other of Maftick; of both which take the following account.

$$
\mathrm{D}_{2}
$$
Having 
Having provided three quarters of a pound of gum Sandrick, mix it with two quarts of Spirits, and having been well fhaken, and ftood for about two days, decant or ftrain it into another bottle, and referve it for ufe. Take alfo of clean pickt Maftick the fame proportion, to an equal quantity of Spirit with the former, and in every particular obferve the rules for making the Sandrick, as to fetling, thaking, decanting, and ftraining it.

Now when you defign to varnifh a print or any thing elfe with this varnifh, your ufual proportion for mixing them, is to add a double part of gum Maftick to a fingle part of gum Sandrick. As for inftance: fuppofe the work would take up or confume three quarters of a pint of varnifh; then by the foregoing rule you muft put half a pint of Maftick to a quarter of a pint of Sandrick-varnifh, and fo accordingly in a leffer or greater quantity. And we, think fit to make thefe varnifhes feverally, and fo mix them, that we may have our varnifh anfwer to our defires in foftnefs or hardnefs. Now when you have fet by your work for two days, you may try its qualities, if, by preffing your warm finger on it, you leave your print behind you, tis a fign that it is too foft, and a wafh or two of the Sandrick will harden it: if it not only refift your touch, but hath fome ftreaks, flaws, or cracks, like fcratches, fometimes more or lefs, you may be fure tis, too hard, and it muft be remedied by a wafh or two of your Maftick-varnifh. Some ufually diffolve thefe gums together, and others mix them before hand, and by fo doing are not certain how their yarnifh will fucceed; for it often happens, that fome parts ur suob gumi arc fofter than others, and fo the contrary. Should therefore a varnifhed piece prove too foft, or hard, this way cannot remedy it ; for to wafh it again with the fame, is only a repetition of the former mifcarriage. Thefe things being premifed, I need not infer which way will prove the moft rational, certain, and fatisfactory.

To make Varnifh, that foall fecure your Draught, whether Gold-work, or Colour, from the injuries of Tarnibing, and will give it a gloss.

Before we come to the Varnifh, tis requifite to acquaint you with the manner of preparing Turpentine, which is the chiefeft ingredient. Take then of good Venice-turpentine as much as you pleafe, inclofe it in a Pipkin that will hold double the quantity that you put in. Having prepared a fire that will never flame out, but burn gently and clearly, fet your pot over it, but be cautious that it boil not over, thereby to prevent the firing your Turpentine and your Chimny. To this gentle boiling motion caufed by the fire you muft join another, and with a ftick very often ftir it, until you find tis rendred fit for ufe; which you may difcover, by dropping a little of it on the ground; for when tis cold, it will crumble to powder between your fingers, if it be fufficiently boiled; and when tis brought to this pafs, nothing remains but that you let it cool, and preferve it for the following compofition. 
Your Securing-varnifh réquiires a quarter of a pint of the fineit Seed-Lacc-varnifh; (which is always the top of it, ) and one ounce of this boiled Turpentine finely powdered; they muft be börh thut up clofe prifoners in a double glafs-vial or bottle, capacious enougli to contain a double quantity; which being ftopt clotè, thay be plac'd over a very gentle fire, that it may leifurely heat; thereby to foreftall the danger of breaking, the glafs, which it is certainly paft when tis exceeding hot; and in this condition keep it for fome time, fimpering, and finiling : then take it off, and give it vent by unftopping; fo done, return the ftopple fhaking it well, and place it on the fire again, never difcontinuing the operation; but repeat the forefaid method, till fuch time as your Turpentine' fhäll be fo far diffolved, that the bignefs of a large Pea fhall only remainvifi. ble; for that being the drofs and indiffoluble part, will not endure to be incorporated. Being arrived to this degree, remove your Varnifh, afford it two days to cool and fettle; and vouchfafe the clearer part frefh lodgings in a clean bottle, that may entertain and keep it for your future defigns.

Noiv whatfoever you propofe to be by this varuifh fecured, if convenience will allow, fhould be deftined to a warm place, that it may dry the fooner; if you cannot admit of it, then give it the fpace of half an hour to dry between every wath; however it ' will glofs either way. Then take a Pencil, for great work large, and fo the contrary, proportionable to your draught? with this Pencil dipt in the varnifh, fecure it, that is. pafs it otror, leaf by leaf, and iprig by fprig, not omitting to give your Rocks, Figures, \&c, the like entertainment; but be fure above all, that your fteddy hand never trefpafs upon the leaft part of your black or ground-work: Having run over all your draught thus, three or four times, for oft. ner may fpoil the colour of your nnetal, you may reft fatisfied that your undertaking (whether of Gum-water, or Gold-fize) is armed againft all injuries and Tarnifh; and, if performed Artift-like, adds to the native luftre of the metals, with an artificial glofs more bright, durable, and furprizing.

\section{To fesure your whole piece, both Draught and Grossid-wark, whereby it maj endure polifb. ing, and obtain "Glo/s all over, like fome of the Indian performances.}

Here alfo, as in the laft, your patience muft be defir'd, and before we open our Scenes, think it reafonable to give you a furvey of thofe paffages which muft be tranfacted in the Tiring-room or Shop, before the Actors and Operators appedr on the Stage. Thit neceffary and ferviceable friend, Venice-Turpentine, here alfó gives his attendance: who in the quantity of one pound, to three pints of water, takes up his lodging in a clean, earthen, Pipkin, almoft as large again as the Inhabitants: Thefe Guefts fo difpofed of, with their houfe of clay the Pipkin, place over a gentle fire, and by de: grees warm them, till they being pleafed with their habitation be: gin to fimper, and dance a little s then do you pronote their par $\mathrm{E}$. ftime 
ftime by ftirring with a ftick, (as in the laft Chapter you were directed.) But if they finding the place too hot for them, fhould endeavour to efcape by boiling over, which youl foon difcover by the rout and buftle, and rifing of the water; releafe them, not from the Veffels but fix the Pipkin in a cooler place; yct fo, that they may, always dance, and boil leifurely. If you find that a little of this Liquor being pour'd an the ground, if cold, is willing by your fingers to be reduced to powder, you may conclude that the operation has. fucceeded well, and ought now to be concluded. Having stood long enough toloofe its acquired heat, and will fuffer you to handle it; part thefe fellow-fufferers, by taking the Venice-Turpentine into your wet hands, and therewith fqucez from it its friend the water, as clean as poffibly; roll it into the figure of a ball, and after a day or two pound and beat it into fine powder, and in a fit place fet it to dry; but not too near the fire; which will melt it; and laftly; imprifon it in a Gallipot.

This Operation is juft like the former; but the two Turpentines are at variance, and differ in their colours; for this is as white as Paper, the other, in the laft Chapter, as yellow as Amber: You niuft therefore of neceffity judge this moft excellent for the prefent ufe; : although tis more often to be wafht with it, before it will endure and acquire a glittering Polifh.

Having advanced thus far, let us now proceed to compofe the Varnith, by joining nne ounce of this powder'd Turpentine to half a pint of Seed-Lacc-varnith, in a dortie twice as large as the things you put in, clofe ftopt. When it has ftood fome finall time on an cafie fire, take it off, unftop, and thake it: be fure to do fo, until the Turpentine be diffolved to the bignefs of a large Pea; and after two days have both cool'd and fettled it, decant and feparate the cleareft, which is now in readinefs for your work. Your piece therefore lying before you drawn and finithed, waiting for fecurity againft all damages, fortifie after this manner. Take aneat, clean, varnifh-Pencil, large or fmall, as your work is in its Area, furface and breadth; for a large Table or Box requires a great Pencil, and fo the contrary. This Pencil being dipt into a Gallipot; wherein you have poured forne of the faid varnifh; when you take it out, always ftroke it againft the fides of the pot, for fear it fhould be too full and overburthened with varnifh, which will incur this inconvenience, That'twill lie thick and rough in fome places, whereas a fimooth and even fuperficies is its greateft beauty. This, without any diftinction, muft wafh over your whole work, both draught and ground: And you muft do it five or fix times, as you fee the gold and metals keep their colour, gently warming and throughly drying it between every wafh; and indeed it muft be but juft warm, for if more, 'twill ruine all your labour. Having obferved thefe rules, as alfo that it muft by all means be evenly and fmoothly done; let it have reft fot three or four days before you attempt 
any thing further upon it. After this time is paft, provide fome Tripole, fcraped with a piece of glafs, and a fine rag, which dipt in a bafon of water, and forne powder of the fame Tripole being lickt up by the faid cloth, therewith in a moderate way, neither too hard or too foft, rub and ftroke, until it becomes fmooth and gloffy; but if it fhould come fo near your gold or draught as to moleft and difplace it, utterly defift, and rub no more there, but let your chief aim be to render your ground or black, bright and fimooth, for there your wavings and unevenefs will be moft difcernable. Now to fetch of the Tripolec, take the fofteft Spunge foak'd in water, and with it wafh it off, and a clean cloth or rag to dry and free it from all the Tripolee that remains. But becaufe this will not free the crevifes and fine lines from it, mingle a little oyl with a like quantity of Lamblack, and greafe your Table all over with the fame: now to fetch off this too, labour and rub with a fine cloath, until your Lamblack and Oyl vanifh and difappear. To conclude this tedious bufinefs; Take one fine clean rag more, and therewith rub and ftroak until a glofs is acquired, and that it gliffen and reflect your face like a Mirror or Looking. glafs.

I fuppofe by this time it is apparent, what trouble, pains, care, and accuracy; accompany our Undertakings; and if to thefe you prefix the Skill, Fancy, and fine Hand of the Artift; I fay all thefe muft enhance, and fet an high price upon good Japan-work.

Thefe inftructions for compofing Varnifhes, the muft needful. aud bett for all works of this kind, being thus fully laid down; it will be no ways prejudicial to give fome Rules, which muft be moft. ftrictly obferved in all forts of Varnifhing, and to inform you how you may employ thefe Varnifhes about other Woods; or to lay Blacks, and other colours, which are much in vogue with us and the Indians. We grant, it is not a part of Japan-work properly, but rather foreign to that defign, but its univerfal benefit will a. bundantly compenfate for that pretence, and the knowlcdge of it cannot certainly prove burthenfome to any: But to thofe efpecially it is advantageous, who living in the Country remote from Artifts, cannot without great trouble move or alter any thing they have by them, unlefs affifted by this our information.

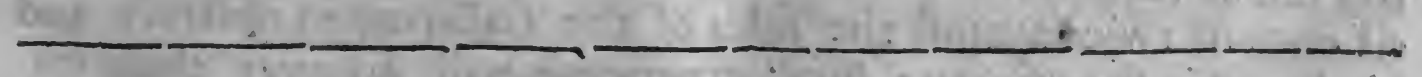

C H A P. III.

\section{General Rules to be diligently obferved in all manner of Varnißhing.}

Am very follicitous that your Work fhould fucceed, and there1 fore take all imaginable care to guide you, fo that you cannot poffibly mifcarry ; and in order thereunto fhall propofe.Rules and

$$
\mathrm{E} 2 \text { gene- }
$$


general Cautions, which I defire you would have always in mind, and call thein to your affiftance in all your undertakings.

I. Therefore let your wood which you intend to varnith be clole-grained, exempt and free from all knots and greafinefs, very imooth, clean, and well rufh't.

2. Lay all your Colours and Blacks exquifitely even and fmooth; and where ever mole-hills and knobs, afperities and roughnefs in colours or varnifh offer to appear, with your $\mathrm{Ru}$ (h fiveep them off, and tell them their room is more acceptable to you than their company. If this ill ufage will not terrifie them, or make them avoid your work, give them no better entertainment than you did before, but maintain your former feverity, and with your Ruth whip them off, as often as they moleft you.

3. Keep your work always warm, by no means hot, which will certainly blifter or crack it; and if that mifchance through inadvertency hould happen, tis next to irreparable, and nothing lefs than fcraping off all the varnifh can rectifie the mifcarriage.

4. Let your work be throughly dry, after every diftinct wafh ; for neglect in this point introduces the fault again, of which we warned you in the fecond rule, That your varnifh thould not be rough and knobby.

5. Let your work lie by and reft, as long as your convenience will admit, after tis varnithed; for the better will your endeavours prove, the longer it ftands after this operation.

6. Be mindful to bogin ynur varnifhing ftroak in the middle of the table or box that you have provided for that work, and not in full length from one end to the other; fo that your bruth being planted in the middle of your board, ftrike it to one end; then taking it off, fix it to the place you began at, and draw or extend it to the other end; fo muft you do till the whole plane or content be varnifhed over. We have reafons too for this caution, which if neglected, has feveral faults and prejudices attending it; for if you thould undertake at one ftroak to move your Pencil from end to end, it would fo happen that you would overlap the edges and mouldings of your box; this overlapping is, when you fee the varnifh lic in drops and fplafhes, not laid by your brufh, but caufed by your bruthes being at the beginning of the ftroak overcharg $d$ and too full of varnith, and therefore we advife you to ftroke your pencil once or twice againft the fides of the Gallipot, to obftruct and hinder this fuperfluity; fmall experience will difcover thefe miftakes.

7. When you come to polifh, let your Tripolee be fcraped with glafs or a knife: for fine work your rags muft be fine, and your Tripolee too delicately fmall, and powder-like; and fo for common work, coarfe linnen, and coarfer Tripolee will be very ferviceable: let your hand be moderately hard, but very even, in all your polifhing-ftroaks; and remember to polifh and brighten one place, as much as for that time you intend to do, before you forfake it, and pafs over to another. For 8. Re- 
8. Remember, never to polifh your work as finooth as you intend at one time, but let it reft two or three days if you can after the firft polifhing, and then give it the finifhing and concluding ttroak. Be circumfpect likewife that you conic hot near the wood, to make your piece look thin, hungry, and threadbare! thould you therefore injure your workmanfhip after this manner, it will demand another varnifhing for fatisfaction and reparation.

9. Take a large quantity of Tripolec at the firft polifhing, till it begins to become fmooth; afterwards, a very finall parcel will fuf fice. Circumfpectly examin your Tripolee and clout, leaft forne mifchievous, unwelcom gravel, grittinefs, or grating part, unawares fteal in, and rafe or fcratch your work; it will prove no ea fie matter to hide the flaw and damage : and if ever it fhould fó happen, you muft retrieve your negligence by your labour, and with your cloath wrapt about your forefinger polifh the faulty place until you have brought it to a good underftanding and evennefs with the reft of the pieee, and the wounded part to be no more vifible.

Io. When you refolve to clear up your work, and put it in its beft apparel, remove and wafh off your Tripolee with a Spunge and water : drink up that water with dry linnen, and with oyl mixt with Lamblack anoint the whole face of your work; let no corner or moulding efcape, for this will totally free your piece from the lurking Tripolee. Now tis time that thefe fhould withdraw, and as they turned out the Tripolee, fo muft a clean linirien rag difplace them, and put them to thift for new quarters; and then with anothor clean, very tine, loft, dry cloath, rub it all over; fpare no place, or pains, but falute it all with a nimble, quick ftroak, and as hard an hand, and the fruits of your induftry will be a daz-。 ling luftre, and an incomparable glois.

Laftly, for white-work, be kind and gentle to it, let your hand be light and even, and your skill in polifhing it reat and curious; and obferve, that when tis to be cleared up, you muft not pollute and dawb it with Lamblack, but oblige it with oyl and fine flower inftead thereof.

To conclude, let this Chapter be well ftudied, aud remember, that without it you cannot regularly or fafely perform the task: This is the Common-place-book, to which I fhall continually refer you; and if you will prove negligent and remifs in this particular, I thall prophefic, that nothing can fo infallibly attend you as Error and Difappointment. 


\section{GHA P. I V. \\ of varnifhing W coDs without Colour. \\ To varnifb Olive-wiood.}

VV Hat remains then, but that from Precept we proceed to Practice, that from mean and ordinary endeavours we fucceflively rife to the excellence and perfection of this Art. To begin with Olive-wood, which for Tables, Standś, Cabintets, \& 2 , has been highly in requeft amongtt us; that which is cleanly workt off, void of flaws, cracks, and afperities, is a fit fubject for our skill to be exercifed in. Having rufhed it all over diligently, fet it by a weak fire, or fome place whicre it may receive heat and in this warm condition, wafh it over ten or tivelve times with Seed-Lacc-varnifh, that remained after you had poured off the top for a better ufe, with a pencil proportioned to the bignefs of your Table or Stand, or the like; let it throughly dry between every wafh; and if any roughnefs come in fight, rufh em off as faft as you meet with them. After all this, welcom it with your Rufh until tis fmooth, and when very dry, anoint it fix feveral times with the top or fineft part of the aforefaid Seed-Lacc-varnifh. After three days ftanding call for Tripolee fcraped with a'knife; and with a cloth, dipt firft in water, then in powdered Tripolee, polifh and rub it till it acquire a finoothnefs and glofs : but bel circumfpect and hie of rubuing too murch. Which witl fret and wear off the varnifh, that cannot eafily be repair'd: If when you have labour'd for fome time, you ufe the rag often wetted, without Tripolee, you will obtain the better glofs. Then wipe of your :Tripolee with a fpunge full of water, the water with a dry räg; greafe it with Lamblack and Oyl all over; wipe off that with a cloth! and clear it up with another, as I have moft fully thewed in the ldift Chapter, to which I refer you. 'If after all this pains your work look dull, and your varnifh 'mifty, which polifhing 'before tis fdry, and damp weather will effect; give it a flight polih, clear it up, and that will reftore its priftine beauty. If you have been too niggardly of your varnifh, and there is not enough to bear and entidure a polifh, ufe again your fineft Seed-Lacc, and afford it four or five wathes more; after two days quietnefs polifh and clear it up. Should any one defire to keep the true natural, and genuine colour of the wood, I council him to employ the white-varnifh formefly mentioned, as every where anfwerable to his purpofe; for this being of a reddifh tawny colour, and fo often wafhed with it, muft neceffarily heighten and increafe the natural one of the Olive.

To varnifh Walnut-wood.

To avoid a tedious and troublefom repetition or tautology, I thall refer you to the laft Chapter, and defire you to obferve the 
The Art of fapanning, Varnißhing, \&

fame method exactly for varnifhing Walnut, that I gave you for Olive. And farther take notice, that thofe Rules will hold good alfo for all forts of wood, that are of a clofe, fmooth grain, fuch are Yew, Box, the Lime-tree, and Pear-tree, \&c. "Thus much may fuffice for varnifhing woods without colour; we pafs over froini hence to treat of the adorning woods with colour, and of each in its order.

\section{CHA P. V: \\ Of varnifhing Woods with Colour. \\ Of Black Varnifbing or Fapan.}

B Lack yarnifhing is done in imitation of Japan-work; and be$B$ caufe the making this very good is a great ornament to the whole undertaking, I thall give you the beft account 1 can polftbly for the making it. Having provided wood, clore-grained, ditd well wrought off, rum it finooth, and keep it warm by a fire, or ith fome hot place; but,be always cautious, that whilf you varnifh; you fuffer not the piece to take the eye of the fire, that is, come fo near it as to burn, fcorch, or blifter your work, which is an unpardonable fault, and remedied no other way when conmitted but by fcraping off the varnifh, as I hinted in the Chapter of 'Rules and Directions: Thofe that inake it their trade, generally work in a Stove, which, is beyond all difpute cre bett and fafeft way; and 1 would advife thore, who intend to make it their imployment; to ufe no other; becaufe it gives an even and moderate heat to all parts of the room: but thofe who for pleafure, fancy, and diverfion only, practife; for them I fay, a great fire in a clofe, warm, - chamber, may perform it as well. In the next place, pour fome of the thickeft Seed-Lacc-varnifh into a Gallipot, adding to it as much Lamblack as will at the firft wath blacken and difcolour the work; the Colour-hops furnifh you with it for $2 d, 4 d$, or $6 \mathrm{~d}$ the barrel, whofe price is equal to its bignefs: With this varnifh and black inixt together varnith over your thing three times, permitting it, to dry, throughly between every turn. After this, take more of the Lac-varnifh, and mix with it Lampblack to the lanie degree of thicknefs with the former. This is the onty black for this butinefs; I prefer it before Iyory, (tho fome differ with me on this point;) this is a fine, foft, and a very deep black, and a grees beft with the varnith; how you thall make, it, I will in the next Section direct you. With this black compofition wafh it over three times, between each of them rufhing it fmooth, and fuffering it cleaverly' tơ dry: Then with a quarter of a pint of the thickeft Seed-Lacé, mix of Venice Turpentine the bignefs of a walnut, and thake thetn together until it is diffolved, and obferve this proportion in lefs or greater quantities: Now put in Lamp-black enough to colour it 
and no more, and with this wafh it fix times, letting it ftand $t i$ hours between the three firft and the three laft wafhings. Having thus cloathed the piece with ordinary varnilh as with a common under-garment, we now intend to put on its gayeft apparrel, and cover it all over with the top and fineft of the Seed-Lac-varnith, which muft alfo be juft coloured and tinged with the Lamp-black: twelve times muft it be varnifhed with this, ftanding as many hours between the fix firft and the fix laft wafhings, with this never to be forgotten caution, That they ftand till they are dried between every diftinct varnifhing. After all this give it reft for five or fix days before you attempt to polifh it; that time being expired, take water and Tripolee, and polifh it according to the directions I have affigned and taught you in the Chapter for Olivewood: but however take along with you this further remark, That you allow three times diftinct from each other for polifhing; for the firt, labour at it till tis almoft fmooth, and let it ftand ftill two days; the next time, polifh till it is very near cnough and fufficient: lay it afide then for five or fix days; after which; laftly, polith off, and clear it up as you were before inftructed. Following this courfe, I have, I will afture you, made as good, as gloffy, and beautiful a Black, as ever was wrought by an Englifh hand, and to all appearance it was no way inferior to the Indian.

I promifed to detect and lay open the whole Art, and do refolve by no means to fall fhort of my engagement. I intend therefore to pleafure you with a nother way to inake good Black, and having variety you may take your choice, and try either, as your fancy or Genius is inclired. I muft confefs, I have made excellent good black this way too, and fuch as in all refpects wuuld match and parallel the foregoing. Lay your blacks as before, and take of the beft-Seed-Lac-varnifh, and the White-varnifh, (I mean the firft White that I taught you to make in this Book) an equal quantity, and youchfafe to give it a tincture only of your Lamp or Ivoryblack; wafh your work with it fix or eight times, let it ftand the fpace of a day or two, and dry between every turn; then repeat it four or five times more, keeping it but juft warm, and having refted a day or fo, anoint it as often with the fine Seed-Lac-varnifh on1y. To conclude, in a weeks time, after all this has been done, it will be dry enough to polifh, and not before, which you may then do, and clear it up. You will obferve, that your glofly perforinances after fome little time may happen to wax dull, mifty, and heavy; which a llight polifh will remedy, with clearing it up afterward. Now the caufes of this difappointment ate two; cither firtt, your yarnifh is not reafonably well dried, or it has not a fufficient body of varnifh; both thefe occafion it to mift, and, as it were, to purl. Tis no hard task to diftinguifh them: if the former is in fault, it will appear dull, but of a full body, and fmooth; if the latter, the work will look hungry, and fo bare, that you may almoft, if not quite, fee the very grain of the wood through your 
varnifh. This laft fault is mended by five or fix wathes inore of your fine Seed-Lacc; the other is affifted by frequent polifhings, with difcretion. One Memorandum I had almoft paffed over in filence, which I prefume I have not any where mentioned; You muft look upon it as a neceffary remark; and by no means to be omitted, and this it is; To be induftriounly careful, in laying on your colours and varnifh, never to ftrike your pencil twice orer the fame place, for it will make your varnifh or colours lie rough and ugly: but let every ftroak anoint a place not wafht before, carrying a fteady, quick, and even hand; beginning at the middle of the table, and fo conveying your brufh to either end, until the whole furface has been paffed over. Perhaps I have here fpoken the fame thing over and over again ; in juftification whereof, I alledge what Seneca did to thofe, who objected that he was guilty of tautologie, and repetition; "I only (fays he) inculcate often the " fame precepts to thofe who commit and react the fame vices: This is my cafe; if you charge me with that fault, ny plea is his; I often admonifh you, and infert many cautions which refer to the fame error, and apply 'em to thofe who are fubject to frequent mif carriages.

\section{To make Lamp-black.}

Being furnifhed with a Lamp that has three or four Spouts, for as many lights and cotton-week, which you may have at the Tallow-chandlers, twifted up fo big that it will but juft go into the nofe of your Spouts; for the greater light they make, the larger quantity of black is afforded. Procure a quart of oyl, by the Oyl. fhops rated at $6 \mathrm{~d}$. and fo much will make black enough to ufe about a large Cabinet. Get a thing to receive your black in, fuch in fhape and fubftance as you may often fee is planted over a candle to keep the flame and fmoak from the roof or ceiling of a room. Having placed your weecks in their proper apartment, and put in the oyl, fire or light 'em, and fix your receiver over them fo clofe, that the flame may almoft touch them. After it has continued fo the fpace of half an hour, take off your receiver, - and with a feather ftrike and fweep offall the black on it. Snuff your weecks, and put it on again, but forget not to fupply your Lamp with oyl, as often. as occafion thall require; and when you imagine more black is ftuck to the receiver, do as before directed : and thus continue and perfevere, until you have obtained black enough, or that all your oyl is burnt up and exhaufted. 'This is that which is properly' called Lamp-black, and is of excellent ufe for black varnifh.

\section{White Varnifhing or Fapan:}

You cannot be over-nice and curious in making white Japan; nothing muft be ufed that will either foil or pollute it, in laying on the colour, or in varnifhing. Your firft neceffary therefore is Ifinglafs-fize, (to make which the next Section fhall infruct you;) 
fcrape into it as much whiting, as will make it of a reafonable. thicknefs and confiftence; or fo long, till by a ftroak with your pencil dipt into it, it will whiten the body which your bruft has paffed over; your own difcretion is the beft guide. Suffer it not to be in extreams, either too thick or too thin; but with your brufh, made of the fofteft Hogs-hair, mix and incorporate very well the whiting with your fize. This being prepared, whiten your work once over with it, and having ftood till tis throughly dry, do it all over again; and when dry, repeat it a third time: after which let it ftand twelve hours, but be fure to cover and defend it from duft before tis varnifh $t$. Take then fome rufhes; rufh it as finooth and as clofe to the wood as you can conveniently. This done, procure fome white flake; with which the Colour-fhops can furnifh you; mix it too with your fize only, that it may lie with a full, fair body on your piece. With this, three feveral times whiten your work, giving it fufficient time to dry between each of them; then rufh it extraordinarily fmooth, but be not now fo bold as you were before; adventure not to come near the wood; but by all means keep your diftance. Thefe two forts of white being ufed, we charge you with a third, and that is, white Starch, boiled in fair water, until it come to be fomewhat thick, and with it almoft blood-warm wafh over the whole, twice; never forgetting that it Thould dry between every turn. After 24 hours reft, take the fireft of your white-varnifh, and with a pencil (firft wafhed in fpirit to clean it from duft) anoint or vainifh your work fix or feven times, and after a day ov two do the like again. Thefe two fits of varnifhing, if done with a fine careful hand, will give it a better glofs than if it were polifh' $t$; if not fo accurately performed, tis requifite to polifh it; and in order thereunto, you muft beftow five or fix wafhes of varnifhing more than to the former : fo that if tis done fo well, that it ftands not in need of a polifh, two turns of varnifhing will fuffice; but if it muft be polifh't, three are abfolutely required, befides a weeks reft before you begin polifhing. Care and neatnefs thould attend this operation from one end to the other; for in poliffing, your Linnen and Tripolee inuft be both of the fineft; your hand light and gentle, your cloth neither too wet, or too dry; and when you clear it up, and give it the finifhing, concluding ftroak, fine flower and oyl muft be admitted to the performance, but Lamp-black utterly laid afide and excluded.

\section{To make Ifinglass-Size.}

Take an ounce of Ifinglafs, divided or broke into finall pieces ; let it ftand in a clean Pipkin, accompanied with a pint and a half of fair water, for twelve hours together. Place the veffel in a gentle fire, fuffer it to boil mighty leifurely, and continue finiting and fimpering, till it is wholly confumed and diffolved in the water. After the water it felf is wafted and boiled away to a pint or lefs, letripve it, and let it ftand in a convenient place to cool. This when cold, 
cold will turn to a Jelly, which we call Ifinglafs-fize. You are advifed to make no more than what will ferve your prefent occafions, for two or three days will totally deprive it of its ftrength and virtue. Tis of great ufe, not only in the foregoing white-varnifh, but feveral other things, hereafter to be inentioned.

To make Blew-Fapan.

This task calls for feveral ingredients, and thofe too diverfly prepared, before they can be admitted to the compofition. In the front white-lead appears, which muft be ground with Gum-water very finely on a Marble-ftone: The next in rank is fome of the beft and fineft Smalt, (to be met with in the Colour-fhops,) which you muft mix with Ifinglafs-fize; adding, of your white-lead fo grinded, a quantity proportionable to the Blew you intermix with 'em, or as you would have it be in ftrength of body. Alt thefe well ftirred and temper'd together, being arrived to the confiftence and thicknefs of common Paint, wath over your work with it, and, when perfectly dry, do the like three or four times, until you obferve your Blew lies with a good fair body; if it thould fo fall out, that the Blew thould be too pale and weak, put more Smalt, and no white-lead into your fize. Having rufh't it very fmooth, ftrike it over again with this ftronger Blew : foon after, yet not till it is very dry, with a clean pencil give it, at two feveral times, as many wafhings with the cleareft Ifinglafs-fize alone; and lay it afide for two days carefully covered, to preferve it from duft: The fame diligence forget not in making White-Japan, which does as abfolutely require a covering, until either of them is fecured by a proper mantle of their own, varnifh, which is fufficient to guard 'em againft all injuries of duft or dirt. But to proceed: When you have warmed it by the fire, imploy again your cleaneft pencil, dipt in a fmall portion of white-varnifh, anointing your work feven or eight times; defift then for one day or tivo, after which wafh it again as often as before. Lay: it afide for the fame fpace of time, which being expired, repeat your wathes the third and laft time, as often as formerly. So many operations certainly deferve fome leifure minuts, and a week at leaft muft be pafs'd over, before you dare prefume to polifh it. When that is done, with Lamblack and oyl clear it up, and lend it a gliffening, finooth, and pleafant countenance. Obferve, that vour Blews being more deep and dark, thin or pale, depends wholly upon the different quantities of white-lead, that are mixt with the Smalt after the firft wafhes: for as a fmall proportion of Lead introduces the firft, fo a greater plenty occafions the latter.

Let this ferve for a general caution in laying either Blews, White, or any other colours with Ifinglafs-fize; Lct it not be too ftrong, but rather on the contrary very weak, but juft fufficient to bind your colours, or make them ftick on your work : for if it be otherwife, it will be apt to crack and flie off. But laft of all, 
when you lay or wafh with clear Ifinglafs, to keep you varnifh from foaking into, or tarnifhing your colours, then let it be of a ftrong and full body.

\section{To imake Gum-ivater}

Hardly any can be ignorant of the making of this; tis very common, and eafie, and the compofition confifts of two bodies on1y. In three quarters of a pint of fair water diffolve one ounce of the whiteft Gum-Arabick, carefully and cleanly picked: If you keep ftirring and thaking it, the fooner 'twill be diffolved; which done, ftrain it through a fine Holland-rag into a bottle, and if you want it, ufe it.

\section{To make Red-Gapan.}

This beatuful colour is made feveral ways, and we want not drugs and mixtures to vary the different Reds, and humour all fancies whatfoever. I fhall confine their variety to three heads: I. The common ufual Red; 2 . the deep, dark; and laftly, the light, pale Red. Of thefe in their order.

In contriving the firft, Vermilion defervedly claims the chief place: Tis mixt with common fize by fome, by others with the thickeft of Seed-Lacc. The laft I judge moft fit and ufeful, for this reafon; becaufe it will not then break off in polifhing, as that mixt with fize frequently does: neither is it more chargeable, feeing it helps better to bear the body of varnifh that fhall be fpread over it; Your mixture thould keep a medium between thick and thin ; tis difficult, and almoft impoffible in affign exact Rules for iningling your Colours, in general we tell you between both extremes; finall practice and experience will mafter this feeming difficulty. Your work being ready and warm, produce your Vermilion well mixt with the varnifh, and falute it four times with it; then allow it time to dry, and if your Reds be full, and in a good body to your liking, rufh it very fmooth : fo done, wafh it eight times with the ordinary Seed-Lac-varnifh, and grant it a repofe for twelve hours; then rufh it again, though flightly, to make it look fmooth. And laftly, for a fine outward covering beftow eight or ten wafhes of your beft Seed-Lacc-varnifh upon it: and having laid it by for five or fix days bring it forth to polifh, and clear it up with Oyl and Lamblack.

The next in fucceffion to be difcours'd on is the dark, deep Red. When you have laid on your common Red as before directed, take Dragons-blood, reduce it to a very fmall duft or powder, and as your judgment and fancy are inclined, mix it, a little at a time, with your varnifh; and indeed you will find, that a very fimall portion will extreamly heighten your colour, as alfo that every wafh will render it deeper; but when you find it has acquired a colour almoft as, deep as you defign, forbear, for you muft remember you have more varnifh of Seed-Lacc to lay on, which will add and fupply what is wanting. Confider therefore how many wafhes 


\section{The Art of faparning, Varnifbing, \&}

are ftill to be laid, and according to that uife your Sangutis Dràconis; or Dragons-blood. This performance differs no way froin the for mer, but muft be managed by thofe rules given for polifling and elearing the other Red, the Sanguis only excepted.

But in the third place, to oblige any perfon that is an admirer of a pale Red, we affign thefe inftructions. Take white-lead fine: 1y ground with your Muller on the Marble-ftone, you mift grind it dry; mix it with your vermilion till it becomes paler than you would have it, for the varnifh will heighten it : ftir therefore vermilion, white-lead, and varnifh together very briskly; which done; give your work four wafhes, and then follow clofely the prefcriptions laid down for the firft Red varnifh: You muft in the forcgoing mixture confult with your felf, how inany times you are to varnifh after the Red is laid; for if many, confider how they will increafe and heighten the colour, which for thāt reafon muft be paler, and häve a more large portion of white-lead allotted it. By thefe means we have opened a fpatious field, we have difcovered the very nature of the thing; our.Art has been freely difplayed, and we have been neither penurious or niggardly in our communications: What admirable Products may we expect, when a lively and unlimited fancie is exercifed in an Art that is equally boundlefs and uneonfined.

\section{To lay or make Chéfnut-colour-gapan.}

This colour is now very much ufed, and of great eftecin, efpecially for Coaches; I have alfo made other things, as Tables, Stands; and Looking-glafs-frames. I mint nf nocefficy declare, that it fetg off Gold and Metals well : and becaufe variety in every thing that is new is acceptable, but chiefly to the ingenious Gentry, for whom thefe pages are intended, I could not in filence pafs this coloul over.

The things that make up this colour are Indian Red, or elfe Brown red Oaker, which will ferve as well : of either, what quantity you iniagin will ferye your turn, and with a Muller or Marble-ftone grind it, mixed with ordinary fize, as fine as butter. From thence tranflate it to a pottinger; then take a little white-lead, and laborioufly grind it after the former manner, and with the fame fize : In the third place, have Lamblack ready by you; mix this and the white-lead with the Indian Red or Oaker in the pottinger; ftirring and incorporating them together. If the colour produced by thefe three be too bright, darken it with Lamblack; if too dark and fad, affift it with white-lead; this do, until you have mafters ed the colour you wifh for: One thing here commands your memory and obfervation; The fame colour exactly which you make when tis thus mixt and wet, will alfo arife when tis varnifhed, although when tis laid and dry, twill look otherwife. Now when the colours are thus managed in the pottinger, fet it over a gentle fire, put to it fo much common fize as will give it a fit temper to work, (neither too thick, or too thin.) Being thus qualified for 
bufinefs, call for a fine proportionable Hogs-hair brufh, with it wafh over fimoothly your piece ; let it dry, and repeat until your colour lie full and fair. Again, give it a drying time, and rufh it fimooth, but by no means clofe to the wood, unlefs you intend to begin your work anew, and varnifh it a fecond time. After a days reft, adorn it with three or four wathes of the fine Seed-Lacc-varnifh; when that is alfo dried on, varnifh it up to a body, fit to receive a polifh, with your white varnifh. To conclude, its due and neceffary time being. fpent, polifh and clear it up with Lamblack and $\mathrm{Oy} 1$.

To make an Olive-colour.

This performance is every way anfwerable to the former; only inftead of thofe put Englifh Pinck : grind it with common fize, and when it has attained the confiftence of butter, convey it to a pottinger, and there Lamblack and White-lead mixt with it produce the Olive-colour; if too light, Lamblack will prevent it, if too dark the other. But farther, if you think it looks too green, take raw Umber, grinded very fine with fize; add of that enough to take away that greenefs : And nothing then remains but a due heed and obfervance of the foregoing rules for. Chefnut. But before we leave this Section, remember, That all colours laid in fize will not endure fo violent a polifh as thofe in varnifh, but are more fubject to be rubb'd off.

By thefe methods you máy make any colour you can fancie; with this admonition, That all colours, which are light and apt to tarnifh, and loofe thoirglofy heauty with Seed-Lace, mult be humour'd and varnifhed with White-varnifh, the Seed-Lacc being prejudicial.

\section{CHAP. VI.}

\section{To work Metals or Colours with Gum-water.}

T T Tenfoever you defign to work Japan in Gum-water, you $\checkmark$ are advifed to mix all your Metals and Colours, and every thing you make ufe of, with this Gum-water. But becaufe there is no general Rule without exceptions therefore we underftand all colours, except thofe which before we called Tranfparent ones, for they require a different and diftinct way of operation, as the beginning of this Treatife has directed.

When you defign a mixture, forget not to ftir the ingredients very well, together with the water, in a Mufcle-1hell, which I conceive is more proper for this undertaking, and for that reafon defired you to furnifh your felf with a great number of them. Be cautious, I befeech you, that you make not the mixture of your metals or colours with the gum-water either too thick or thin, but endeavour to keep the golden mean between both, that it may run 
The Art of Japaning, Varnifing, \&ic.

fine and finoothly from your pencil, Befide, be not prodigal, 1avifh, and profufe of your metals, but make a quantity requilite for your prefent bufinefs only, and provide not for time to come; for from a mixture of this nature, made in too large a proportion, feveral inconveniences arife. As firft, in fome fhort time, the metals ftanding ufelefs, wax dry, fo that they muft be wetted for a fecond emploiment with the faid gum-water, which by repetition corrupts both the metal and the colour, by receiving too much of gum in them: and although this might be likwife prevented, by adding fair water inftead of that mixt with gum; yet in fpite of all care and diligence, and beyond expectation too, another trouble and fault accompanies it, and that is, the duft will gather to them and render'em unfit and unferviceable. Again, for your colours efpocially, your Shells muft be often fhifted and changed, otherwife the gum and colours will be both knobby and drie, ip that unfeemly pofture fticking to your fhells. I believe it will be your own negligence, and the fault will lie at your door, if after every minute caution and remark, whereby you may not fail of fuccefs if they are obferved, you thould through inadvertency mifcarry. But to proceed : Your metals or colours thus prepared, well mixed, and ready. for the bufinefs, ftir them with the pencil about the fhell, and draw it often on the fide of the fhell, that it may not be overloaded with the metal, when you defign to draw fimall ftroaks; on tho on ther fide, not too drie, becaufe you, muft be careful in making all your ftroaks full and fair, by no means thin and criggy; carry your: hand even and fteddy, and finifh vour line before you draw off your. hand, otherwife you may incur making the ftroak uneven, and bigger in one place than another. But when you attempt great broad things, as Leaves, or large work, then charge your pencil very full, with this provifo only that it does not drop. Here is one obfervation to be made for Gum-water, which in Gold-fize is ufelefs and unneceffary, and indeed very advantagious for learners, and the unskilful efpecially, and by them in a particular nazanes. to be remarkt and obferved. But firtt, tis ufeful for all; for that place you intend to make your draughe in muft be rubbed with at Tripolee-cloth: the reafon is this; your black, when cleared up, will be fo gloffy; and as it were greafie, that your metal or coloux will not lie on it, unlefs it be primed with the Tripolee in that manner. So when you find any fuch greafinefs on your work, rub it with your Tripolee-cloth, and permit it to dry; after which you will perceive the draught of your pencil to be linooth and neat, and to your liking and fatisfaction.

Now that which I before fpake of in behalf of beginners is this; It may very reafonably be fuppofed, that a practitioner in his firft attempts may not frame his piece even and regular, or his lines at a due diftance : now upon thefe or any other accounts, if he is difpleafed at his own handy-work, he may with this ufeful Tripoleecloth wipe out all, or any part which he thinks unworthy to ftand, 
and on the fame fpot erect a new draught; by thefe means he may mend, add, blot out, and alter, until the whole fabrick be of one entire make, good and anfwerable to each part of the undertaking. I cannot better in words exprefs my felf, or with my Pen :deliver more full or plain rules for mixing your colours and netals; neither can I with my tongue more fteadily guide your hand and pen. cil. I am apt to flatter my felf fo far, as to believe what I have communicated may abundantly fuffice, and fhall therefore add nothing more with relation to laying metals or colours, and the manner or method of working them in Gum-ivater. That part of our Profeffion which we call Setting off, or, which is the fame thing in other words, Seeding of Flowers, Veining of Leaves, Drawing of Faces, and making Garments, defires not our prefent confideration, but fhall be handled in the following pages.

\section{CHA P. VII.}

lus biving

\section{To make Gold-jire.}

TrHis is the other famous compofition, which is in great efteent and ufe for laying metals and colours, and ought in due manner to be made known; but we hall firft give you the method of mixing thofe things which are concerned in its production. "Their names and quantities are, of Gum animæ one ounce; Gum Efpal-

- tum one nunce, Lethergi of Gold half an ounce; Red-lead, brown Umber, of each the like portion. To thefe, thut altogether in a new earthen pipkin, large enough to hold one third more than you put in, pour of Linfeed oyl a quarter of a pint, of drying oyl half a pint, with which you may be furnifhed at the colour-shops. Place this earthen veffel thus loaded over a gentle fire, that does not flame in the leaft, keeping it continually fo warm, that it may but juft bubble up, or almoft boil; thould it rife over, your chimny and materials would be in danger : if you perccive it fivelling, and endeavouring to pafs its bounds, remove it from that hot place to a more cool and gentle. When firft it begins to fimper and boil a little, with a ftick keep moving and ftirring it, until the whole mafs of Gums be incorporated and melted; not that you muft defift or forbear ftirring until it become as thick and ropy as Treacle, for then it is fufficiently boiled. This done, convey the pipkin to a cool place, and there let it reft, till the extremity of heat is over. After which time; ftrain it through a coarfe linnen cloth into another earthen pot, there to cool, and lie ready for ufe.

This is the manner of its compofition. I fhall now infert the ways of working it. When your bufinefs fhall call for this Size, bring forth what quantity you require for the prefent, and put it into a mufcle-fhell with as much oyl of Turpentine as will diffalve the fize, and make it as thin as the bottom of your Seed-Iacc. 
Hold it over a candle, and, when melted, ftrain it through a Linnen rag into another fhell. To both thefe add vermilion enough to make it of a darkifh red; but if this make it too thick for drawing, afford it as much oyl of Turpentine as will make it thin enough for that purpofe. The main, and indeed only defign of this Size, is for laying on of Metals, which after this manner muft be performed.

When you have wrought your work, and that which you intend to decipher on it; draw this Size all over that part, and that part only, which you refolve thall be guilded or adorned with gold, paf fing over thofe places where you think to lay your other metal or colours, as Copper, Silver, or the like. Your Size being thus wrought for the Gold, let it ftand till tis fo dry, that when you put your finger upon any of it, it may be glutinous and clammy, and ftick a little, but not fo moift that the leaft fpot or fpeck fhould come off with your fingers, not unlike to thick glue when tis half dry. When you fird it agrees with the characters. we have given you, conclude that to be the critical minute, the very nick of time, wherein you muft apply your Gold; then take a piece of foft, wafht leather, or the like: this being wrapt about your forefinger, dip it into your gold-duft, and rub where the gold-fize is laid, for it will ftick on the fize, and no where elfe. If any duft of Gold lies fcattered about your work, with a fine varnifhing-brufh, that hath not been ufed, brufh or wipe it all into your gold-paper. This being thus finifhed, take your pencil in hand again; draw that part which you defign for Copper with Gold-fize alfo; and when dry, cover it with Copper after the fame method that you received for Gold. A third time weild your inftrument, the pencil, and lay Size for Silver, and operate as aforefaid; fo likewife for all dead metals, wherefoever you defign them: Only take this remark along with you, That you lay your metals fucceffively one after another, fuffering each to dry and be covered, before you begin a diftinct one; as for inftance, Your Gold-fize nuft be dry, and guilded before you proceed farther, and fo of the reft. After all thefe, lay your colours with gum-water if you are pleafed to infert any, referving the Rocks for the laft labour; which how to perform, in the fucceeding difcourfe thall be demonftrated.

It may often fo fall out, that you'l mix more Gold-fize than at one time may be confumed, or you may be called off from your bufinefs for a day or more. Now to preferve it entire and moift $e$ nough, and in condition fit to work againft next time, obferve that after it has ftood five or fix hours, a film or skin will arife and overfpread the furface of it: then put it in water,and let it remain there with the pencils covered too, until your next operation fhall defire their affiftance; before which, you muft ftir it well together, and employ it as you think fit. If it thould chance to grow thick, the old remedy, Venice Turpentine, will relieve it. But farther, if by frequent mixture with Turpentine, often putting into water, or 
long ftanding, it becomes skinny, thick, and knobby, and by con. fequence unferviceable; the beft ufe you can poffibly put it to, is to caft it away.

I thall conclude this Chapter with my requefts to you, fo to order and compofe your Size, that, being of a good mediocrity, neither too thick or thin, it may run fmooth and clear, and your ftroaks be fine and even; in fome time you will be fo skilful, and fo delighted with your draught, that the moft fubtle, neat, and hairy lines will adorn your piece,and your work in all good qualities may, though not exceed, yet vie with, and parallel the Indian.

\section{CH A P. VIII.}

\section{To varnif Privits with White Varnifh.}

PRocure a Board very fit and exact to the Print you refolve to I varnifh, and thus manage it. Get common Size, which you may have at the Colour-grocers; wirming it by the fire, fcraping whiting into it; make it of an indifferent thicknefs, and with the fofteft hogs-hair-bruth, proportionable to your board, wafh it once over, permitting it to dry: then white it again, and fo repeat, till it lies with a fair body, and quite covers the grain of the wood, which may be of Deal, Oak, or any other. This done, take off your whiting with rufhes very clofe, and fmooth, but not fo far as to difcuver the grain : then with flowes and water make a pafte thick as ftarch, and with your hand or brufh work or dawb over the backfide of your Print, with an even fteddy hand lay your Print on the board, and ftick it on as clofe as you can with all imaginable diligence. Suffer it not to cockle, wrinklé, or rife up in little bladders; if it thould, prefs it down with your hand, but be fure your hands be extraordinarily clean and free from all duft, filth, and pollution when you come to pafte on the Print, that it may not in the leaft be foiled, before tis varnifhed. Smooth down the whole paper with your hand, pafs it over and over, that every part thereof may ftick clofe and adhere to the whiting. I cannot here burden you with too many cautions and caveats; for if any the leaft part of your Print rife or bubble, the whole beauty and pride of the Picture is deftroyed when you come to varnifh. Bcing thus clofely and carefully fixt to the board, fet it by for 24 hours, or longer; then taks the cleaneft of your Ilinglafs-fize, and with a foft pencil wafh over your Print; but be certain it be dry before you pass it over again, which you muft do with a quick hand, and not twice in a place; give it leifure to dry, and afford it one wafl more, with two days reft: Afterwards with the fineft and cleareft of your white-varnilh grant it fix wathes by a gentle heat, not too nigh the fire, to aroid bliftering. When 24 hours 
are paft, give it eight wafhes with the faid clear vamilh: lay it afide for two days, and then, vouchfafe to amoint it fix or feven. times more, giving it leave to reft two or three days. Having advanced thus far, with linnen and Tripolee, both very fine, polifh it, but with gentle and eafie ftroaks. Laftly, clear it up with oyl and flower.

This I muft needs commend for a pleafing and ingenuous contrivance; a new fort of Speculum or Lookinglafs, which without deceit gives a double reprefentation. Here the Prince and Subject may (and not irreverently) meet face to face; here I may approach my King without the introduction of a Courtier: nay, tis fo fur. prizing, that though I expect no hadow but that of my friend graven on the paper, it will in fpite of me, in an inftant too, draw my own Picture, fo to the life, that you might without perjury fwear tis the Original. Amorous piece! That (without the affiftance of a Cunning man) obliges me with a furvey of my Self and Miftrefs together; and by this clofe conjunction, by thefe fceming careffes of her in Effigie, I counterfeit, nay almoft antedate our more fubftantial enjoyments! Kind Picture too! which will permit me to gaze and admire without intermiffion, and can furvey me as I do her, without anger or a blufh! I know very well no Apelles dare pretend to delineate or make an artificial beauty, that thall equal her natural: Know, that the perfections of her Bo. dy as far furpafs the skill of the Pencil, as thofe of her Mind tran: fcend the expreffions and abilities of the Pen. But yet, in one circumftance, and onc only, the Picturc does excel my Miftrefs; the thadow is more lafting than the fubftance; She will frown, wrinkles and old Age muit overtake her; but here the lives always Young, for ever blooming; Clouds and Tempelts are banifh t from this Hemifphere, and the bleffes me with gracious and perpetual Smile.

\section{H A P.IX:}

How to lay Speckles or Strewings on the out, or infide of Boxes, Drawers, Mouldings, \&ic.

$\mathrm{H}$ Aving in readinefs a quantity of Speckles, which you think may anfwer your prefent occafion, mix them with fo much of your ordinary Lac-varnifh, as will, being put both into a Gallipot, render them fit to work with a fuitable Pencil, but by no means fo thick as you would Colours. For this ufe only you muft referve a Brufh, with which you muft ftir em very well, and your work being gently warmed by the fire, walh it over with it, and when dry, again. This repeat, until your Speckles lie as thick and even, as you could with or defire them; afterwards beautifie them 
with three or four wafhes of your' Varnifh mixt with Turpentine, and you have concluded all, unlefs you intend to polifh; for then, having done every thing as above directed, tis required that you give it eight or ten wafhings of your beft Lac-varnifh, which being all fucceffively dried on, you are at liberty to polifh it. All forts and variety of coloured Speckles may be thus ordered, except Silver, the laying on of which choice metal deferves the beft and fineft of your Seed-Lacc, inftead of the ordinary; and the beft white-varnifh too, muft be emploied to bring it to a polifh; but if you conclude upon not polifhing it, be more fparing of your varnifh, for fewer wathes will fuffice.

\section{H A P. X.}

\section{Tolay Speckles on the drawing part of Fapanework, as Rocks? Garments, Flowers, \&c.}

REfore you can proceed to try this experiment, a little Sieve muft be framed after this manner. Take a fmall box, fuch as Apothecaries employ for Pills, fomething larger in compars than a Crown-piece, about half an inch deep: Atrike out the bottom, and in its place bind very ftrait about it fine Tiffanie, and to prevent coming off faften it on the outfide of your box with thread, and referve it for your neceffities.

Now when your work expects to be adorned with Rocks, Flowers, or the like, ufe firft your Pencil to varnifh thofe places with, and whilft it is wet put fome of your ftrewings into the Sieve, and gently thake it over the place defigned for your Rock, until it appears anfwerable in Speckles to what you intended; but efpecially when for Rocks, call for a pencil about the bignefs of your finger, one that is drie and new, and with it fweep all thofe ftragling Speckles, that lie beyond the wet or varnifhed part, into the fides and top of the Rock that is thus moiftned; for there it will not only ftick, but render your work, thicker of Speckles in thofe places, more beautiful, and oblige it with a kind of fhadow and reflection.

This work admits of no idle hours, no interludes and vacations, for as foon as one part is compleated, the other defires to undergo the skill and contrivance of the Artift. When this Rock is drie, the next muft fucceed in operation; and by this way of working the one, when, and not before, the other is perfectly drie, you may, like the Giants of old fighting againft Jupiter, caft mountain upon mountain, lay one rock upon or befide another, of different colours, and as many hapes, until the whole enterprife of Rock-work is completed. But obferve, that in fiveeping your Speckles into the edges of each Rock, you intermix not one portion of fcattered 
The Art of fapanning, Varnifling, \&.

parts into a Rock of a different colour; let them therefore enjoy their proper ftrewings. When you thus lay your Rocks on your work being cold, it will certainly for the prefent look dull and heavy, nay to that degree, that you might very well figgeft to your felf nothing lefs than the damage and ruine of the whole undertak: ing. But though no figns of life, beauty, or fhadow do appear, let: not this ftartle or difcourage you; for when you have fecured it, as we directed before, this fright vanifhes, the dangerous Mormo or Bugbear difappears, its expected qualities fuddenly arife, and by the affiftance of your Securing-varnifh, it is decked with gay and beautiful apparrel.

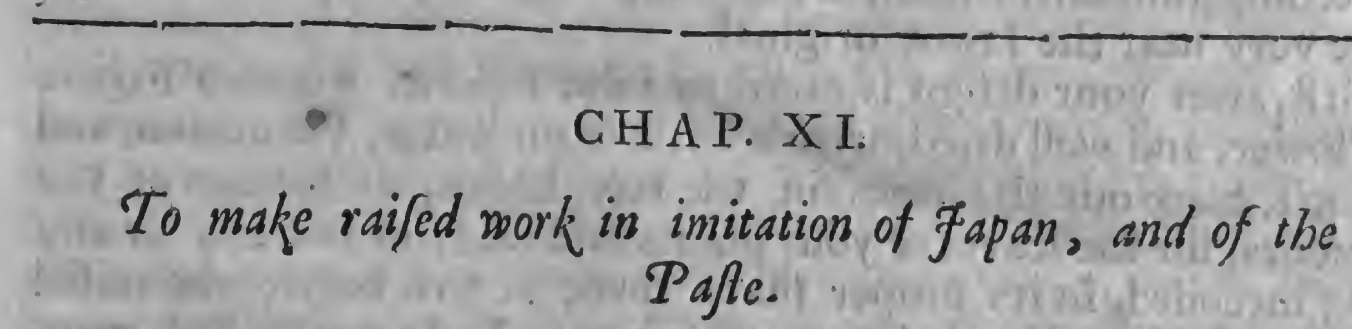

TOattempt the compofition of this Pafte, you muft provide a 1 ftrong Gum-Arabick-water, charged with a double quantity of Gum to that we before taught you. Have in readinefs an ounce of Whiting, and a quarter of an ounce of the fineft and beft BoleArmoniack; break them on your Grinding-ftone with the Gumwater, until they are made as fine as butter, but fo thin, that when moved into a Gallipot, it may but juft drop from the ftick with which you work and ftirit. If its condition be too thick, gumwater will relieve it ; if too thin, you muft give it an addition of Whiting and Bole-Armoniack, as much as witl máke it capable of working well, and regularly. The ftick that I fpake of before fhould refemble that of a Pencil-ftick, but it chint have a more fharp and taper end. This dipt into your pafte, drop on the Rock, Tree, Flower, or Houfe which you purpofe to raife, and by repetition proceeding until tis raifed as high and eyen as you think convenient. Prevent all bladdering in the pafte, which fcurvie fault proceeds from a carelefs and infufficient grinding and ftirring of the Whiting and Bole: fhould you with thefe blemifhes endeavour to raife, your work when dried will be full of holes, sand thereby deftroy the beautie of it. The only way to prevent it in fome meafure, when fo dried, is, with a wet fine cloth wrapt about the finger, to rub it over again and again, until the holes and cracks are quite choak't and ftopt up, and after its time of drying is expired, with a rufh and all imaginable induftry and care fmooth it.

Thefe affiftances I have laid down only in cafe of neceffity, by way of corrections for accidental mifcarriages ; for your work will look abundantly neater, if thefe Errata are prevented by a Pafte in the beginning, well grinded and tempered before tis dropped on your work. You are defired farther to obferve, that in the Japan 
raifed-work for Garments, Rocks, \&c. one part is elevated and higher than the other; as in flowers, thofe that are firft and neareft to the eye are higheft, fome leaves too that lie firft are higher: than thofe that lie behind 'em : So in the pleats and foldings of garments, thofe which feem to lie underneath, are aliways at the greater diftance. I will inftance in but one more, and that is of Rocks, where in pofition the firft muft always furmount and fwell beyond that which skulks behind, and is more remote: The rule holds good in all things of a like nature, and if you endeavour to counterfeit the Indians who take thefe meafures, tis reafonable and. neceffary to follow their prefcriptions. I thall affign two ways for its accomplifhment, which, if truly and carefully copied out, will come very near the Japan original.

Firft, after your defign is rais'd to a due height, whether Figure or Flower, and well dried, with a little Gum-water, Vermilion, and a Pencil, trace out the lines for the face, hands, or foldage of the garments, for the leaves of your plants and feeds of flowers, or any thing intended, in its proper thape made at firft before the raifed work was laid, and according to which your Pafte was in fuch manner directed, and confined by thofe lines that were drawn as its boundaries; for unlefs fuch ftroaks were made, tis impoffible to laye the pafte in its proper figure. This done, three or four finall inftruments muft be procured; one of them a bended Graver, which the Engravers make ufe of; the reft, fmall pieces of Steel, in thape like a Chiffel of the Garpenters. faftencd in a wooden handle, the breadth of the largeft, not exceeding a quarter of an inch, of the others fizeably lefs: With thefo your raifed work muft be cut, fcraped, and carved, leaving one part higher than the other, keep. ing due regard to the proportion of the thing you defign. But here I muft forewarn you of the difficulty. of the enterprife; no heavy, ruftick hand muft be emploied in this tender, diligent work ; for if in hafte or unadvifedly you attempt it, believe me your raifed work will break off in feveral places, to the difgrace of the Artift, and deformity of the piece. Let therefore your tools have an exquifitely fharp and finooth edge, whereby they may cut clean and fine without roughnefs: And now tis time to finooth and fleek it with a brufh that has been often ufed before, in order, in the laft place, to cloath it with any metal you thall judge moft proper, as fhall hereafter be thewed at large:

The other way which we promifed for raifed work, is this: Strike or trace out your defign, as well the infide as the outward; that is, the fhape of your face, neck, hands, legs, the chief ftroaks of the foldings of the under and upper garments, fo of flowers, or the like: Then take your Pafte, fomewhat thinner than you commonly ufe it, and with it raife the lower garments or parts, which require the leaft raifing. Grant it time to drie throughly, and then with a very fmall pencil dipt into the thickeft of your Seed-Lace, varnifh juft the edges of your raifed work; for this intent, that when you advance 
The Art of Japaning, Varnibitig, \&c.

advance the higher part, it may hinder the wet incorporating with the drie, which muft be avoided; for fhould it do fo, the work will never thew well. This muft be performed as often as you elevate one part above another; and ftill as your work is exalted, your pafte muft be thicken'd and raiting each part fucceffively; beginning with the loweft, you are to conclude with the uppermoft ; and when all is drie, if need require, fimooth it with a rufh, and then it is in a condition fit to receive your metal. Make ready then what fort of metal you pleafe to cover it with, mixed in gum-water, and with a pencil deftined for the ufe lay it on the raifed work full and fair: give it leave to drie, and with a dogs tooth, which you may have at the Guilders, or a Stone or Agat, by them emploied in their Frames and Guilding, burnifl your work untll it is bright, and fhines as much as you defire it dhould. And farther, dip the pencil into your fineft Lacc-varniffi, and laie it over twice; then fet it off, or fhadow it with what your fancie directs, but of this I thall difcourfe hereafter. Take notice, that if you grind more pafte than you can confume at once, and it be drie before you thall have occafion for it the fecond time, grind it again, and tis fit for your bufinefs. You may judge of the ftrength of your pafte, by the eafie admittance of your nail prefs'd hard upon it, for then tis too weak, and muft be hardened and ftrengthened by a more ftrong gum-water: Trials and Experience will give you more accurate, more fatisfactorie directions. With thefe ingredients, joined to Art and Skill, it is poffible to make a pafte fo hard, fo ftubborn, that a violent froak with an hammer can neither break or difcompofe it.

\section{CH AIP. XII.}

To prepare ordinary, rough-grain'd woods, as Deal, Oak, \&c. whereby they may be fapanned, and look well.

PRovide ordinary Size, ufed by the Plaifterers, and vended by Colour-fhops, diffolve it over the fire, making it pretty warm; mix Whiting with it until tis of a reafonable body and confiftence, yet not too thick; then take a Brufh fit for the purpofe, made of hogs-hair. Lay your work once over with this mixture of Whiting and Size, and fo often repeat it, until you have hid all the pores, crevifes, and grain of your wood, fuffering it to drie throughly between every turn. You may afterwards take a fine wet rag, and rub over your work, making it as fmooth as your induftry is able; this furbifhing it with a cloath dipt in water, we call Water-plaining; when drie, rufh it even and finouth, and as clofe to the grain as poffibly you can. This done, wafh over your work twice with the thickeft of your Secd-Lacc-varnifh; after

$$
\mathrm{K} 2 \text { which, }
$$


which, if it be not fmooth, again rufh it, and in a day or fo varnifh it over with black, or any other colour, as you have been directed in thofe places where we have treated of it ; when it has ftood fufficiently, you may apply your felf to finifh it by polifhing.

According to thele methods you are to prime-carved Frames for Cabinets or Chairs, when you defire they fhould look well; with this difference, that thefe muft not be polifht, and by confequence require not fo great a body of varnifh, no more than will contribute to a rich and plendid glofs. There is alfo another way, which I recommend for the moft valuable, becaufe the moft durable and lafting, but not indeed of fo large an extent as the former, being proper only for the tops of Tables, Boxes, or thes like; and thus you muft proceed. Boil common Glew in water, tlet it be fine and thin; into which caft the fineft Saw-duft, until tis indifferently thick, and fit to lay with a brufh, which you muft. provide for that purpofe. Run it overionce with the glew fo mixt; if the grain of the wood be not effectually obfcured, wath it again, and two days being given to harden,fend it to a good workman or Cabinet-maker, who muft fcrape it with his Scraper, as Pear-tree or Olive-wood are ferved, and make it as fine and evén as poffibly he can; then varnifh it as you have been learnit to do by Pear-tree, or any other fimooth wood. This, if well done, will not coine bchind any for beauty or durability. Tisl confefs'd, thefe labours are to be performed only uponcafes of neceffity, for they are very troublefom; and if every circumftance were truly wighed, not fo cheap or valuable as your finooth, clofergrained woods, of all which Pear-tree is in the firft place to be efteemed.

\section{Of BantaM-work.}

- Think it moft proper in this place to fpeak of the manner of 1 working at Bantam, becaufe the way of preparing the wood is much the fame with that of priming with Whiting. There are two forts of Bantam,as well as Japan-work: for as the Jipan hath flat lying even with the black, and other lying high, like émbofled work; fo the Bantam hath flat alfo, and incut or caryed into the wood, as a furvey of fome large Screens, and other things that come from thofe parts, will beyond all fcruple convince and fatisfie yout: with this difference however, that the Japan-Artift work's moft of all in Gold, and other metals, the Bantain for the generality in Colours, with a very fmall fprinkling of Gold here and there, like the patches in a Ladies countenance. As for the flat work, it is done in colours mixt with gum-water, appropriated to the nature of the thing defigned for imitation: for the ordering thefe colours with gum-water, you have already received inftructions. The carved or in cut work, is done after this manner: You Cabinet or Table, s 


\section{The Art of fapanning, Varribing, ect.}

be it whatfoever you pleafe to work on, fhould be made of Deal, or fome other coarfe wood; then take Whiting and Size, as before taught, lay it over your work, permitting it to drie between every wafh; this muft be fo often done, till your primer or whiting lic almoft a quarter of an inch thick; but always remember to mix your whiting and fize thinner than formerly, and lay it therefore over the oftner; for if tis too thick, it will not only' lie rough and unfeemly, but twill be apt to flie off and crackle. Having primed it to its due thicknefs, being drie, water-plain it, that is, as wc hinted before, rub it with a fine, wet cloth; in fome time after rufh it very fimooth; lay on your blacks, and varnith it up with a good body, and next of all in fome fpace polifh it fufficiently, though. with a gentle and eafie hand. Beirig thus far advanced, trace and ftrike out your defign with vermilion and gum-water, in that very manner which you intend to cut and carve it, and very exactly; your figtires, Trees, Houfes, and Rocks, in their due proportions; with foldage of Garments, leafing of Trees, and in a word, draw it as if it were to ftand fo without any alteration. This finifhed, exercife your Graver, and other inftruments, which are made of flapes, differing according to each workman's fancie: with thefe cut your work deep or thallow, as you think beft, but never carving deeper, than the whiting lies, for tis a great error to pafs through that and carve your wood, which by no means ought to feel the edg of your inftrument. Be mindful likewife to leave black ftroaks for the draperie of garments, and the diftinction of one thing from another: as for example, if you were to work in this manner the great Bird, which is in the IIth Print at the end of this Book; You ought, I fay, to carve where the white is, and leave the black untouch't, which thews not only the feathering of the wings, but the form and fathion of the Bird it felf; the fame means are to be ufed in all other things which you undertake. But I fhould counfel that perfon, who defigns to imitate Bantam work, to endeavour to procure a fight of fuitie Skreen, or other piece; for one fingle furvey of that will better inform him, thin ten pages can inftruct or demonftrate. Had it been a thing of little trouble, or which might have been ufeful to the voung and willing practitioner, we had inferted a Plate or two of it, for it differs vaftly from the Japan in manner of draught; but fince tis now almoft obfolete, and out of fafhion, out of ufe and neglected, we thought it a thanklefs trouble and charge to affix a Pattern, which could neither advantage Us, or oblige You : I think no perfon is fond of it, or gives it houfe-room, except fome who have made new Cabinets out of old Skreens. And from that large old piece, by the help of a Joyner, make little ones, fuch as Stands or Tables, but never confider the fituation of their figures; fo that in thefe things fo torn and hacked to joint a new fancie, you may obferve the fineft hodgpodg and medly of Men and Trees turned topfie tur: vie, and inftead of marching by Land you fhall fee them taking 
journeys through the Air, as if they had found out Doctor Wilkinfon's way of travelling to the Moon; others they have placed in fuch order by their ignorance, as if they were angling for Dolphins in a Wood, or purfuing the Stag, and chafing the Boar in the middle of the Ocean : in a word, they have fo mixed and blended the Elements together, have made a league between fire and water, and have forc't the clouds and mountains to thake hatids, nay deprived every thing of its due fite and pofition, that if it were like any thing, befide ruin and deformity, it muft reprefent to you the Earth, when Noah's Floud was overwhelining it. Such irregular pieces as thefe can never certainly be acceptable, unlefs perfons have an equal efteem for uglie, ill-contrived works, becaufe rarities in their kind, as for the greateft performances of beautie and proportion.

But to return to our bufinefs. When you have finifhed your carved work, and cut it out clean and finooth, with your pencils lay the colours, well and purely mixt, into your carved work, in the manner which your ingenuity fhall fuggeft, or the nature of it abfolutely require. When the colours are finifhed, the gold may be laid in thofe places where you have defigned it, with powdergold, or brafs-duft mixt with gum-water, but that looks not fo bright and rich as Leaf-gold, which the Baptam Artifts always employ; and fo may you alfo, if you make a very ftrong and thick Gum-Arabick water, which you muft laie with a pencil on your work, and whilft it is wet take leaf-gold, cut it with a very fharp fmooth-edged knife (on a piece of leather ftraitly nail'd to a board) in little pieces, fhaped to the bignefs and figure of the place where you difpofe of it. Take it up with a little Cotton, and with the fame dab it clofe to the gum-water, and it will afford a rich luftre, if your water be very ftrong; otherwife 'twill look ftarv'd and hungrie, when tis drie. Having thus finifhed your work, you muft very carefully clear up your black with oyl, but touch not your colours, left you thould quite rub them off, or foil them; for this is not fecured, as the other Bantam flat-work is; if wet come at this, the colours will be ruined, and peel off. I confefs I have feen fome even of the raifed-work, whofe colours would not ftir, but none fo fecured and firm as flat, in which you'll feldom or never find fome Colours that will not endure a fecurity with varnifh, but with the lofs of their native fplendor: but thofe who pleafe may leave out the Tarnifhing colours, and fecure their carved work with a pencil, as formerly directed. 


\section{CHA P. XIV: \\ To take off any Fapan-patterns in this Book, upon any piece of work whatfoever.}

VV

Hen your Black, or any other colour is varnilled and po: lifh't fit for draught, take a particular defign out of this Book, or any thing elfe that is drawn upon paper, with whiting rub all over the back-fide of your Print or Draught, and ufe a linnen cloth to wipe off all the whiting that lies rough and dufty on the back-fide of your paper fo whited. Then lay the Print on the Table or Box, with the whited fide next to it, in the very place where you defign the Draught thould be made, and with a needle or piece of iron-wyer round and fmooth at the point, fixed in a wooden handle for the purpofe, not fharp to cut or fcratch your Paper and Print, which we call a Tracing-pencil ; with this, I fay, draw over and trace the Print as much as you think neceffary, taking the moft material and outward ftroaks, or all others which you imagin are hard and difficult to draw without a pattern. This, by the affiftance of the whiting with which your paper was rubbd, will give the fafhion and lines of what you have dune, upon the Box or Table. After this, if you draw in Gold-fize, ufe Vermilion mixt with Gum-water, and with a finall pencil dipt in it, go over thofe lines made by the whiting; for by this operation it will not eafily come off, fo that you may work at leifure with the Gold-fize. But if you will work your metals or colours in guin-water, then trace or draw over your Defign with Gum-water thixed with Brafs or Gold-duft. Now either of thefe ways here mentioned, when drie and finifhed, will work either in Gum-water or Gold-fize; as I
have formerly difcovered.

\footnotetext{
CHA P. XV.

The manner of porking and Jetting off Jome Draighes in this
Books.

Think by this tinie I may truly fay; That I have in a familiar and eafie method propofed Rules for purchafing inaterials of all forts, the manner of their compofition, with the way of ufing. Varnithes, laying of Metals, Colours, and whatfoever elfe is necelfary, or may claim affinity and relation to the Vafnifhing and Japanning Art. But becaufe thefe lines have a double defign, to infruct and inform the ignorant, as well as aflift thofe that have a 
fmall knowledge and fmattering in this Science: though I am perfwaded I have fufficiently obliged the latter, yet becaufe I may not be fo clear and fatisfactory in my Rules to thofe who before never attempted any thing of this nature, to whom tis a perfect Terra incognita, an undifcover'd Province; for their fakes I thall willingly make an addition of a few pages, to fhew in a plain and more particular manner the way of working fome Patterns in this Book either in Metals or Colours, by the knowledge whereof they may be enabled with eafe and inclination to perform any enterprize that thalloppofe them. To thefe I fhall affix the different ways of fetting oft and adorning your work, which I have before ratther mentioned and touch t upon, than treated of.

The firft eight Copper-prints, at the end of this Book, are feveral defigns for fmall work, of whofe differences their Titles will inform you : Two others for Drawers of Cabinets; one, of all forts of Birds flying in Antick figures; two, of Birds great and lefs, ftanding in various poftures; another of Bealts, \&c. Two figures of Chinefe men and women, in untoward geftures,and habits: Others, of Flower-pots, Sprigs, Trees, and the like: Laftly, their Temples, Structures, and Palaces; their manner of worfhip, and reception of foreign Minifters and Embaffadors; with as much pleafing variety as can reafonably be expected. Any part of thefe may be placed on the work, as the fancy and ingenuity. of the undertaker thall direct : yet I hall give a little light after what manner they may be tranfpofed.

Suppofe then you have a large piece of work, as a Table, or Cabinet; take one of the Prints. which chiefly complies with your humour, infert others alfo which may be moft agreeable, yet give varicty too: borrow a part from one, a figure from another, birds flying or ftanding from a third; this you may practife until your Cabinet be fufficiently charged : if after all this any thing be wanting, your judgment muft order, beautifie, and correct. But obferve this always, that if you would exactly imitate and copie out the Japan, avoid filling and thronging your black with draught and figure, for they, as you may remark, if ever you happen to view any of the true Indian work, never croud up their ground with many Figures, Houfes, or Trees, but allow a great fpace to little work: And indeed tis much better, and more delightful; for then the Black adds luftre to the Gold, and That by way of recompence gives beautie to the Black.

But here an Objection may be ftarted; That if a little work is inoft natural, and according to the Pattern which the Indians have fet us, why have not I followed that Rule in my Draughts annexed to this Book? To this I anfwer; That if I had fo done, I muft have provided thrice the number of Plates, to fhew the variety that thefe have fufficiently done; not to mention a triple charge that would have attended. Again, thould thefe have been Whis 
beautified with little work, I had then been liable to cenfure for being niggardly of my. Patterns, and depriving the practitioner - of choice and variety: But by what I have prefented, I have fecurely failed between this Scylla and Charybdis; have paffed the Rock on one hand, and the Gulph on the other; and, if I an not flattered, have not only obtained the good liking of the Curious; but fufficiently fupplied the wants of thofe who are great undertakers: Here you may alter and correct, take out a piece from one, add a frag. ment to the next, and make an entire garment compleat in all.its parts, though tis wrought out of never fo thany difagreeing Pat. terns. Befides, I have not by this variety fixt a Ne plis ultra to your fancie, but have left it free, and unconfined: I do advife, that no one would oblige himfelf to keep clofe to the Copy, for even the fmall Cutts will fupply the place of a much larger-Box than is there exprefs'd, and not injure or difgrace it. I do with modefty and fubmiffion pretend not to confine, but lead and affift your fancie. Thus much in general terms; I'le detain you no lons ger on this large and pregnant Topick, but regularly now defcend to particulars, and inftruct you how to work off fome of the fore. mentioned Draughts.

\section{To work the Firft Draught.}

This affords you ornaments for the tops and fides of little Boxes, which, when traced out according to the directions already given, muft be done with gold, if you work in gum-water: Take your gold-thell, and with your pencil fill fome of the tops of your houfes; and thofe parts which you obferve in your Print to be mark' $t$ with black lines, as the Doors, Windows, \&c, afterwards the Sprigs, Flowers, and Birds; all of them in a fair, finall, but full ftroak': now if you paint thefe latter things with colours, they may be va. rioully managed, with red, fome others with blew, a third with filver, until the whole be entirely compleated. If you think to raife any of thefe, be fure to practife on thofe that lie firft and foremoft, for which I do refer you to the Chapter of Raifed work.

When you have thus far advanced, tis required that you fhould proceed to Setting off; which I defire now to make my bufinefs to inform you, as having never yet mentioned it; yet I hall at prefent confine it only to that of Gum-water, for this is not the way. with Gold-fize, of which more properly hereafter. When the leaves and tops of your Houfes are fairly laid in Flat-work; to make the black and thining veins of your leaves, the tiling of your buildings, and foldage of garments, appear through your gold and metals, as fome of the Indian work does, exercife your Tracing pencil, breathing on your work with your mouth clofe to it; and when moiftened with your breath, ftreak or draw out the veins and foldage of the figures, their hands, face, and parts fo made in their proper order. When your metal begins to drie, and will not feparate, force it to part again by breathing on it, for that moift- 
nefs will reduce it to obedience, which muft be obferved too in a moderate degree; for if you make it over-wet and damp, the tracing-iron tis true will disjoin it, yet no fooner can it pafs the place but it clofes up, and reduces it felf to its former amicable conjunction; as a Ship that ploughs and divides the Sea, makes a channel in an inftant, but as that fails off the waters return, the breach is healed, and the place of its paffage is no more to be found. Too much moifture is therefore as great an inconvenience as none at all. Perhaps your work may be rough and unhandfom before tis throughly drie, yet after that, a foft, new pencil by brufhing will caft off that difguife, will command the loofe rough particles to withdraw, and reprefent the Veinings and Hatchments in a fmooth and pleafant drefs.

\section{To Set off Raifed.mork with Black.}

When your Raifed work has been varnifhed and burnifhed, put Lamp-black into a Mufcle-fhell, and with gum-water hardly wet it, for if you allow it too large a portion, you'l find it a difficult task to make it comply and incorporate: but when it is mixt, which you muft perform with your brufh, then add as much water as will prepare and enable it, by the affiftance of a fimall wellpointed pencil, to draw fine black ftroaks. Thefe muft frame the lineaments and features of the Faces, -the foldage of your raifed Figures, the veins of Leaves, Seeds, the bodies of Trees, together. with the black hatchments of your Flowers. If you would have any Rocks fpeckled, firft pafs them over with the faid black, and when dry, grant them two walhes with the Securing-varnifh; 1aft$1 y$, lay on the Speckles. One thing here deferves your obfervation; If your good will and labour cannot be accepted, and your black, or whatfoever you Set off with, will not be received; pafs over the Raifed work with a Tripolee-cloth in a foft and gentle manner, left the Metals fhould be feduced, and forfake their apartment.

This manner of Setting off is more practifed than that with a Tracing-pencil, or breathing on it, not only for Raifed but Flatwork too; for when your picce is drie, falute it once with the Securing-varnifl, after which take your black pencil, and employ it in hatching and veining at your own pleafure; other metals and colours defire the fame management : I will give you an inftance; if a red flower were to be Set off with Silver, then muft your'Red be fecured with varnifh : and being firft fuppofed to drie, hatch and vein it with your Silver. "Thefe directions muft be of force and confequence in all cafes where you defign to work one thing on another, whether colour upon metal, metal upon colour, on metal upon metal, without being guilty of falfe Heraldrie. Having adorned and Set off your piece, if it be Flat-work, you may make ufe of the varnifh fpoken of in the $I_{3}$ th page of this Book, to fecure your whole piece both draught and ground-work, which will endure polifhing: but if for Raifed-work, you mult make ufe of 
the other Securing-varnifh, which is fet down in the I 2 th page, and the reafon is, becaufe your. Rais'd-work will not bear a polifh as the other, but muft only be fecured, and cleared up. But here is to be noted, that this latt varnifh may be ufed either for Flat, or Raifed-work, but the former is only proper for Flat. In working with Gum-water be ever vigilant and careful that your metals or colours be not too ftrong of gum, for it will utterly fpoil their beautie and complexion; but when you have fufficiently mixed them in the beginning, fair water afterward may quench their drought. Look upon this as a general, unerring guide; let then be juft fo far encouraged with gum, as may oblige them to ftick clofe to your work, and enable them to endure varnifhing without coming off: If this thould at laft prove a repetition, you muft par. don me; tis a bufinefs that I am very zealous for, and thould be highly concerned to think of a mifcarriage, in the laft, ornamental part of the undertaking; and if you ftrictly examin it, you'l find, if this is not new altogether, yet it may bear a fecond reading; as being a paraphrafe and explanation of the former.

I intimated before, that the Rocks fhould be kaft of all treated of, becaufe not to be finifhed till the reft were compleated; only thofe few fcattered fprigs, fuppofed to grow out of them, that they may not appear bald and naked, nor too full of 'em, left they might confound the eye, and interrupt the fhadow. Now if thefe Rocks are to be covered with metals, with your pencil lay Gold, Silver, or Copper, in a full body round the outward ftroaks, which were traced with your pencil, in breadth a quarter of an inch; prevent its being too wet; call for a large Goofe-quill-pencil, cut off the point, making it flat and blunt at the end: With this touch or dab your Metal, then do the like to the black part of the Rock, whereby that may be fprinkled with fome of the metal too, by little and little continue it until the whole be fcattered over; yet thefe Specks fhould be thicker towards the fides and top, than in the middle. Other metals, artificial and adulterate, may be laid according to thefe directions, and may be dabb'd or workt with your middle finger as well as the Goofe-pencil. Thus much may fuffice for the firft Print, workt in Gurn-water: I thall give fome brief directions how to proceed in fome few more; for by underftanding thofe, you may fafely adventure on any that remain.

The Second Patteris:

This is a reprefentation of Birds, which if you work with gold and colours, I advife that the body of the firft Bird; that ftands before the other, be done in gold, the wings with bright copper, and, when fecured, let its breft be redded a little with verniilion, in that part of it which in the Print is darker than the reft. Then take your black thell, and beautifie the eve, and the touches about it with black; as alfo the feathering of the body and the back; Let 
the wing be fet off or feathered with filver, the long black ftroaks in the feathers of it with black; the tail, legs, and bill with gold, but change the white lines in the tail for black. The bodies of the other Birds may be laied with adulterate, dirtic; dark copper, but the wings gold, fet off the body with the fame; the breft with touches of filver, the wing with black: Laftly, let the tail be bright copper, and feathered with white, the bill and feet gold; Next, cover the Flies body with gold, his wings with bright cops per, hatcht or fet off with filver, the body with black. Make your Bird on the fecond Box-lid with gold, feather and fhadow it with bright gold; let the wing be with vermilion and Lamblack inixt, till tis become a dirtie red; feather it with gold, the quills with filver, the beak gold, and the legs vermilion. Let the other Bird be gold in the body, feathered about the wing (as you may fee in the Pattern). with black; the wing natural copper, feathered with white or filver; let the Flies be gold, and fet them off with black. Beautifie the firft Bird, on the lid of the Patch-box, with bright or red copper; hatch it with filver, touch it about the eye and head with black; make the wing of gold, feathered with black; the feet and bill of the fame metal. The other Bird behind it muft have green gold in the body, feathered with filver; the wing gold as the other, hatcht with black. On the other lid make the Bird gold, the wings bright red copper, feathered with white and toucht with black. The fides of each box may be contrived after the fame manner: the fprigs deferve all to be laid in gold, as the rocks with different metals, and hadowed, but allow the outward ftroaks to be gold, not only as they confine, but as they adorn your work.

\section{The Third Draight.}

Before this piece can be adventured on, you are defired thus to inake a paint or colour for the face and hands of the Figures. Grind white-lead finely on your Marble-ftone; add as much Auripigment or Orpiment, as will give it a tawny colour; if you think it too lively and bright, allay it with Lamblack, which may contribute to a fwarthy complexion, and neareft the Indian: but if you are inclined rather to a pleafant, flefh-like colour, a little vermilion or dragons-blood mixed with it, can to any degree oblige you. Now if you love variety of figures, you may ufe as many mixtures for their countenances; and diftinguifh the Mafter from the man, the Abigail from the Miftrefs by her tawnie skin. Lay then the garment of your Figure in the firft powder-box-lid in bright red copper; , on that part which covers the breft, and encircles the neck, paint vermilion; let the cap and ftick be of gold: fet off the foldage of his vefture with filver, and clofe to each filver-thread join other of black; fet off the black with the fame. Laftly, ftrike out the lineaments of the face, and fhapes of the hands, with black alfo: Let his Lacquey, the boy that attends him, have a golden livery,

$$
\therefore \text { the }
$$


The Art of fapaining, Varribing, \&ec:

the bundle under his arm red; with a cap of filver. Set off the galment and cap with black, his parcel with lines of filver. Order the Bird and Flie to be overlaid with gold, and fet off with black. As for your Sprig, the great leaves muft be green gold and pale copper, border'd with bright gold; your flowers vermilion, encompaffed with filver, and feeded with the fame; garnifl the fimall leaves and ftroaks with gold. The cover to the fecond Box fhould have its firft figure attired in gold, where the black furrounds his neck, vermilion, the forepart of the cap the fame, the hithder gold; his vert buttoned, looped, and drapered with black; the red of the cap and neck edged with filver, the gold of the cap hatcht with black; the feet bright copper, fet off with filver: The other gentleman his companion, that he may have as good apparrel as his friend, let his cap before be gold, behind green gold; fet off the firft part with black, the latter with filver, the covering for his neck with the famie metal; his long robe will require green gold, fet off with bright gold; his feet of the fame, fet off with black. The Flie and Bird juft as the formter, the Sprig in like manner, except the feed, gold, fet off with black. The Figure in the firft Patch-box may be arrayed in bright copper, hatched or let off with filver; the cap and ftaff gold, the tree alfo. The figire on the other little bot thould have his upper coat vermilion, hatcht with filver; the un: der gold, fet off with black; the ftick, bird, and flic, gold; his feet, the colour of his face: The fprig, all gold, except rhe flowers, which may be red and filver, fet off with black and filver. Let the fides be all gold, faving the rocks, which may be filver and copper.

Thus have I directed you in thefe methods of working colours, and how fparingly I have made ufe of them, for the leaft part of them is fufficient : and unlefs even thefe are workt clean, and with good judgment, it were more credit to omit, than infert' 'em. But becaufe fome have a particular genius and inclination that way, I thall not make this Tract fo incompleat as to forfake the treatife of them, and therefore to oblige univerfally the next Section is fubjoined.

\section{How to work in Colours and Gold the great Sprig in the XIIIth Print:}

This has infinite vàriety, and by confequence will require the aid and affitance of very many colours; fo that the Tranfparent ones may be here emploied as well as the others.

Firft therefore trace out your defign, and fill moft part of the finall work belonging to it, as the ftems and little leaves, with gold, paffing by however a few of them, to be referved for bright copper, green gold, or the like; added too in fuch fort, that they may grace and enliven the piece: for tis the cuftom and fafhion of the Japan-artificers, to fill frequently with dead metals, yet bind 'cin in with gold. From thefe fet upon the great leaves and flotvers in the pofture that they lie, and fill 'em by thefe directions, or any 
others of the like kind. But by way of example; The firft great flower next the rock, half covered by great Leaves lying before it, I would fill the feeded part with filver, the leaves with vermilion, and in fetting off, work it in black Diamond-wife, and thofe little fpots of black which lie lurking in the white, with bright red copper; then the part that is filld with red, I fhould bind in with filver, and vein it with the fame. From this. I come to the other on the right hand, and fill the feed of that flower with bright copper, the leaves with filver, and when I come to fet oft, border the feed with black, the infide, with filver; compafs in the leaves with gold, hatching them with black. From hence I march to that on the left, partly hid by a great leaf: the feed of this thall be green gold, its fquares bright gold, the fpots in the fquares vermilion, its leaves with dark heavy copper, fet off with filver. Next for the three flowers that lie fomewhat above this: that in the middle $I$ would do with green gold, the feed bright gold, fquared with black: the other may be laid with filver, feeded with bright copper, hatcht and fquared with black. The laft with vermilion, the feeds with tranfparent green, and enclofe them with vermilion, and hatch in the leaves with filver. From thefe I would proceed to the other flower, oppofite to them on the right hand; fomewhat larger; whofe feed muft be red, bound in and chequer'd with filyer, covering the leaves with blew, hatcht and furrounded with gold: the little one above that with red, the feed with blew, fet off with filyer. From thefe we make our progrefs to the two great flowers above them: the firft may be laid with tranfparent blew, bounded and worked with gold, the leaves covered, with filver, and hatcht with vermilion : the feed of the fecond with dirty copper, fet off and encircled with filver; the leaf of the faid flower cloathed with deep bright red copper, hatcht with black. Next bufie your felf in filling the fingle great flower above that, whofe feed may be dirty gold, environed and fquared with filver; the fpots in the fquares done with bright gold, that part of the leaves that is; white changed for black, and with gold hide the black that lies in the white: the remaining part of the leaf may be laid with bright red copper, bounded with filver, and hatcht with the fame. As for the flower next above that, I would lay the feed in tranfparent red, fet it off with filver, border it vvith black; then make the leaves filver, and hatch it wvith black. Aftervyard, the three above this, I vvould work in the fame manner vvith the lovvermoft three; but that above all, may have his feed bright copper, compaffed and fet off vvith black; the leaves dirty copper, vvhich might be hatcht and enclofed vvith vvhite. Novv remember, I befeech you, that although I have mentioned filling and fetting off together, for the more eafie apprehenfion of it, yet be conftantly mindful to lay all your plain colours, before you think of fetting them off; and the reafon of it is this, becaufe you are more ready to fet off vvith one colour, before you undertake another, and your fancie is more quick 
quick and ready to adorn and garnifh every fingle flower and leaf, Now, fuppofing the flowers filled, let us contrive what fhall be the covering of the great leaves. But to be brief: Deck them with metals, generally fuch as green, dirtie gold ; pale, muddy copper yet intermix here and there blew and green tranfparent: bound and vein 'em with fuch as give the greateft life; not wild, gawdy' colours, fo much as grave, modeft, and delightful. I advife yout fometimes to double your borders in the leaves, with the ground black of the Box or Table left between, as the Print will inform you: And again, make all your veins, finifhing lines, and the ftroaks you fet off with, fine, clean, even, and fmooth. By this time I fuppofe, whofoever fhall furvey thefe laft pages, may imagine we have pleafed our felves with fancies and Chimara's; that we have difcours'd like men in a dream; nothing but Gold, Silver, and the richeft colours can fatisfie our luxuriant fancies; nay, we pretend to have it in fuch plenty too; that Solomon himfelf, compared to us, was a beggar: By our talk we are Mafters of both Indies, Pactolus Sands, and the Mountains of Potofi fhould be oux proper inheritance; for, like Midas, and the Philofophers ftone, we turn every thing to Gold. Our Birds are fo fplendidly arrayed, that all common ornaments are excluded; the beft Dyes fo univerfally overfpread their wings, that you'd imagin they would outfhine the Bird of Paradife. The clothing and livery of the Fields are mean and heavy, when compared to the Flowers our Art has produced, whofe luftre is more radiant, more durable, and furprizing.

\section{CHAP: XVI. \\ To work in Gold-fize the Fwentietb Print of this Book.}

SInce our Gentry have of late attained to the knowledge and dis $S$ ftinction of true Japan, they are not fo fond of colours, but covet what is rightly imitated, rather than any work befide, tho never fo finical and gawdy. The moft excellent therefore in this Art copy out the Indian as exactly as may be in refpect of Diaught, Nature, and Likenefs; in this performance then colours muft be laid afide. Some variety of metals indeed may be admitted, but in a very flender proportion to that of gold, which is the Fac totum, the general ornament of right genuine Japan-work. This undertaking now in hand may be done with gold only; But I thall in the next Chapter choofe a Print, whereon perfect and corrupt metals may be laid. To begin therefore with that of Gold: Be ever cautious and exact when you trace or draw out your defign in vermilion or gold; which being performed with an even hand, call for your gold-fize, ready prepared for the draught; ufe a fmall 
convenient pencil, to mark in your fize the outward lines, the boundaries of that rock, which in the twentieth Print you may perceive lies beyond the Buildings; and although you do begin here, you are not to fill it (either with metals or fpeckles, ) until the other work is concluded; for, if you remember, we charged you before, to finifh the Rocks in the laft place. Again, if I may counfel you, begin with the remoteft part, that which is fartheft diftant from you; for then you will not be liable to the inconvenience of rubbing, or defacing any thing whilft it is wet, with an unwelcom hand, or intruding elbow. Having therefore in fhort undertaken the fartheft part firft, work it juft as the Print is; I mean, draw your gold-fize on the black lines of the Print, and no where elfe; referving the white for the black Japan or ground of your Table. But to explain it a litle more : In all refpects operate with your Size, as if you were to copy the Print on white paper with ink, or black Lead; only take care, that whilft you are bufied in working one part, you fuffer not that already done with fize to drie to that degree, that it will not receive and embrace your metal, but very often try the draught fo lately made: if it is clammy, and fticks fomewhat to your finger, but not fo as to bring off any, then tis high time with your leather to lay and rub on the goldduft : if it clings to your finger fo faft, as to come off with it, then know it is not fufficiently drie; if tis no way clammy, you may conclude tis too ftubborn for the rcception of the metal. This ctveat, being rightly managed, fet upon your drawing part again, and fo continue, now making lines, then guilding them, until the whole be compleated. If you find it a tedious, troublefome undertaking to draw the white, and pafs over the black; or, on the contrary, to draw the black and omit the vvhite on the tops of your houfes, or foldage of figures, faces, or the like; then for your eafe overlay all thofe parts of your building or foldage \&c with goldfize, and when your metal is laid on that, and is well dried, wafh over with Securing-varnifh thofe places only which you defign to fet off with black: which done, exercife your pencil in making thofe lines and divifions that are required to diftinguifh the parts of your houfe, as the Tiling, Draperie of garments, or any thiug of the like nature. The reafon why we enjoin you to wafh with varnifh, is not out of any fufpition or jealoufie that the fize or metal will forfake its allotted feat, but becaufe its furface is generally too finooth and greafie to admit of and unite with the black, unlefs reconciled by the mediation of the aforefaid varnifh. What I have propounded is an example for any other Print, that you could wifh or defire to accompllin in Gold-fize : and indeed I had been very negligent, fhould I have permitted this noble fubject to reft in filence and oblivion; this, which above all others prefents us with the grandeur and majefty of Japan.work; our under-performances vanifh and thrink away, when the Mafter-piece is expofed to view. Let the narrow-foul'd Mifer hug and adore his bags 
bags, and pray to the goldeir Calf that he has erected, I fhall neither envy or comply with his idolatry; for I had rather line my Houfe with that precious metal, than my Coffers:

\section{CHA.P. XVII.}

\section{To work in Gold-fize the twentythird Print of this Book, with perfect or corrupt Metals.}

This draught requires a greater variety of colours than any of the precedent, without which it were no mean or ordinary performance to drefs every figure in its proper habit, and equippe the attendance according to their refpective qualities; but to fhew what Art and Contrivance can effect, we have on purpofe felected this Pattern, which was chiefly defigned for colours, and intend to alter the property, converting it to perfect and mixt metals : fo that if we overcome the moft difficult, all meaner undertakings muft by confequence yeild obedience and fubmiffion. Were I therefore allowed to prefcribe in this affair, I would in the firft place overlay the canopy and curtains belonging to it with pure gold, then flower, and fet them off with black: the two ftreamers or flags may be done in bright copper, faintly thadowed with powderTin, or dirtie filver; for the beft and brighteft filver is to glaring a metal for black Japan, and very feldom if ever made ufe of, (yet I muft acknowledge I have feen feveral Cabinets of Raifed-work come from the Indies wrought altogether in Silver, but that is not authority fufficient for us to practife it in Gold-work.) As for the King, his face and hands fhould not be of the ordinary hue with inferior mortals; Gold beft becomes his Majefties countenance, his eyes and beard black, his cap green gold fet off with bright gold; his body may be cloathed in bright red copper, fladowed with black; the table-cloth covered with green gold, fhadowed or fet off with bright. The figure kneeling by him, fhould have his upper garment done in dirtie gold, thadowed faintly with dirtie filver, but his under in Powder-tin, hatcht with black; his feet with dirty copper. The bottom of the Throne, with the Afcent, you are to lay with gold, and fet it off with black: The Ambaffas dor firft in rank approaching the throne, may be allowed the fame metal for his face with his Majefty, and fet off as his too with black; that on his fhoulders and fleeves with bright red copper, thadowed with black; his prefent in his hand, gold, his cap greengold, fet off with bright; his feather behind it bright copper, fet off with black ; his body dirtie copper, fhadowed faintly with dirty filver, or tin, yet flowered with bright gold; his feet bright copper, fet off with black. The figure immediately following him I fhould clad in gold; the cap may be bright copper, all fhadowed or 
fet off with black; his prefent in his hand, his fhoos and girdle, bright copper fet off with black. The third Gentleman's face, h?nds, and feet, I would work in natural copper fet off with black, that on his head powder-tin fladowed with black; the covering on his fhoulders green-gold, fpotted and hatched with bright gold. His outward apparrel fhould be a lay of bright copper, fet off with black; that in his hand, gold; his under-veftment the fatme, and hatch it with black. The laft figure may have his hands, face, and feet, covered with gold, fet off with black; the upper-garment with green-gold, flowered and fet off with bright gold ; the under, natural copper fet off with black ; that on his fhoulder with bright, red copper, fhadowed alfo with black. The body of the tree can be done with dirty gold, fhadowed and fet off as you fee with bright gold; the leaves of the fame. Laftly, the fruit, bright copper, and hatcht with black.

Thus may you work with Metals only, and vary it according to your fancie. And you may fet off your plain metals, when rubbed on Gold-fize, either with Metals mixed with Gum-water, or Gold-fize ; that is, when your plain Metals are layed, and throughly drie, hatch or work in the Size for fetting off, as you would do with Metals mixed with Gum-water. You may ufe which you pleafe, but tis my opinion that Gold-fize is beft.

I had rather fee an Embaffy thus in Miniature, than take a voyage into China that I might really behold one: not that we have too richly attired his Majefty, and the Ambaffadors, or given them more magnificent habiliments than ever they beftowed upon themfelves. Whether the King is defired to join in the league againft the Tartar, or to ftand Neuter, I cannot truly determine; but by thofe weighty reafons, the Golden Prefents, we conjecture that he may be bribed, and brought over to the party. The Agent feems very zealous in the bufinefs; what will be the iffue and event, lies not in my power to foretel at prefent ; nay, if you fhould have patience to tarry till the revolution of the Platonick year, when every thing thall be in the fame pofture it is now, even then by confequence we fhould be ignorant of it. This indeed I can affure you, I have known thefe Politicians nigh ten years, and never faw them yet in any other manner than, what the Picture reprefents; and do therefore imagin, that there are no hopes of an amicable and fudden conclufion.

We however thall novv fix a period to this Treatife of Japan, as you may perceive by our giddy difcourfe, wrhich feems to imply, that vve have nothing more to fay to the purpofe. Yet give me leave, kind Reader, to offer fomething before vve take our formal leaves of this fubject. Many excellent Arts are buried in oblivion, vvhich muft certainly be afcribed to the neglect of the skilful,vvho never committed them to pofterity by the ufeful con- 
The Art of fapanining, Vanilbing, dec.

veyance of Manufcript or the Prefs; Painting of Glass; and mak: ing it malleable, may ferve for inftances of Arts that have mifcarried, either through the lazinefs or ill nature of the Artifts, who would not communicate their ingenuity to after-ages, or elfe through envy denied it a longer date than themfelves, and foolifhly refolved it fhould not furvive them. Short-fighted ignorants! as if their fame and memory could die whilft their Arts thrived, or that their great Grand-fons fhould admire the invention, without entertaining a juft efteem and deference for its Author. Yet I would not have you miftake me, and furmife, that I have made $a$ circular Preamble, to hook my felf into the circumference; for I propofed this Tract as a means to perpetuate my Art only. I mult confers, I have too great an Efteem for this Pallas of mine, then in the leaft to flight or neglect it; and I think my felf obliged to make as good a provifion for the iflue of my Brain, as that of my Body ; for the firft is entirely my own, but I am forc't to adninit of a Partner in the generation of the latter. I hall never be follicitous for my felf, and look upon Applaufe to be as empty and infignificant after death as before it; and am not in the leaft ambitious to live by another's breath, when I am deprived of my own. If I may be allowed to beftow a hearty Wifh, it. muft be for its Suc: cefs, that it may flourifh and be admired; that from thefe lines; as fron the Serpents teeth which Cadmus fowed, may fpring experienced Artifts, that will inveft it with fplendor and reputation yet with this difference from the parallel, that they may mutually
confpire to eftablifh and eternize it. 



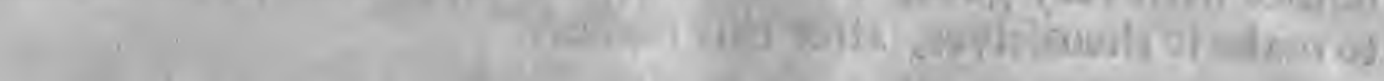

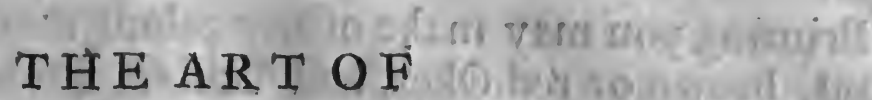

\section{GUILDING, LACKERING, $\sigma$, difplay'd.}

G H A P. X VIII.

\section{To guild any thing in Oyl, mbereby it may fafely be expofed to the weather.}

$\mathrm{VV}$ E have hitherto uttered big and glorious words, hardly a Page that has not ecchoed Gold and Silver; but if you'l pardon us, we will frankly and ingenioufly confefs; that the expreff fions are as valuable as the things: for Brafs-duft, and viler metals have been thus difguifed to counterfeit the more noble and excellent: yet it cannot be denied, but that they are fuch cunning cheats as may almoft impore upon the skilful and ingenious. And this may be faid in their behalf, That although they deceive the eye, they neither pick or endanger the purfe, which true gold would do after a moft profufe and unneceffary inanner. Well then by way of requital we fhall caft away the vizor, and lay afide the mimick drefs; for the Art now in hand will not admit of the for. mer couzenage. Guilding accepts not of bafe materials, is wholly unacquainted with drofs or allay, and the fineft unadulterate gold is the only welcom and acceptable gueft. I am fenfible that the Guilders on metals will quarrel at the name, who pretend, that Guilding is a term appropriated to the working on Metals only: but the difpute is equally trivial, and unreafonable : for if I overlay Wood or any other body with Gold, I cannot conceive how I tranfgrefs the rules of common fenfe or Englifh, if I fay, I have guilded fuch a wood; and I fhall therefore acquicfce in this title, until the frivolous Enquirers furnifh me with a more natural and proper appellation. However, fince fome of that profeffion have upon this occafion difputed the title with me, though to no purpofe, to thew that I can and will be as good as my word, Ile give you their way of Guilding of Metals in full to end the difpute. But to the bufinefs in hand: - I fhall here inftruct you in all things ne ceflary for this way of Guilding, as Primer, Fat Oyl, and Gold-fize, all which are to be gotten at the Colour-fhops. Priming may be ave 
54

The Art of (Guilding, Lackering, \&c.

afforded for $6 \mathrm{~d}$. the pound, the other two will coft each of them $3 \mathrm{~d}$ the ounce: but becaufe they are fcarce commodities, and feldom to be met with very good, tis requifite for thofe who guild much, to make it themfelves, atter this manner.

To make Priming.

Priming you may make of any colour that hath a body; as white' lead, brown or red Oker, and Umber, ground in oyl pretty light : but the Painters have the beft conveniency for this. compofition; for tis made of the fcraping of their pots, the oldeft skinny colours, and the cleanfing or filth of their Pencils. All thefe being mixed grind very well, put them into a canvas-bag that will hold a pint, fowed very ftrongly for this purpofe. If the colour be too dark, it may be alter'd by adding a little white-lead. Being fecurely inclofed and tied up, prefs it between a pair of Screws, fuch as Apothecaries employ, now and then turning the bag, until all the fine primer be fqueezed out, which fhould be received into a Gallipot, the skins and filth that remain are ufelefs, and may therefore be thrown away. With this your piece muft be very thinly primed over, and permitted to drie.

\section{Fat $0 x l$}

Is nothing elfe but Linfeed oyl, managed thus. Put it into leaden veflels, thaped like dripping-pans, but fo, that the oyl may not be above an inch deep. Set them out expofed to the Sun for five or fix months, until it become as thick as Turpentine, the longer it ftands the more fat it will be, and by confequence the Gold will require a better glofs; if it arrive to the confiftence of butter; that it may be almoft cut with a knife, referve it carefully, and as the beft for ufe that can poffibly be made.

\section{Gold-Size in Oyl.}

Provide the beft yellow Oaker, fee it very finely grinded and thick with Linfeed-oyl, which is fomething fat. This done confine them to a pipkin, and put on it fome fat nyl, to keep it from skinning over: cover it with paper, or a bladder to guard it from duft and injury; lay it afide for your occafions. You may ufe it prefently, and if you keep it feven years twill conve to no damage, but on the contrary be much better for your purpofe. Should it happen that you might have old gold-fize that is skinny, and, yellow, and brown Oaker in the fame condition, grind them, fhut them up in a clean Canvas-bag; prefs it between your Screv as your Primer was, until you have made a reparation, and parted the good and ferviceable froin the bad and infignificant; a Gallipbt is a fit receptacle for the firft, and the dunghil for the latter. This fort of Gold-fize is ready to ferve your prefent and more urgent neceflities; if you defire to have a piece extraordinary, I advife you to prime it thinly over once more, allowing it four or five days to drie, if your bufinefs will permit, if not, inftead thereof Lacker over your work in the Sun 
The Ait of Guilding, Lackering, \&ce. Sun, or fome fuch moderate heat, and then tis rightly prepared for
the reception of the Gold-fize.

\section{How to mix, and lay on Gold-fize.}

Take of the beft Gold-fize, and of fat Oyl, an equili quantity; yet no more than your piece requires: Mix and incorporate theni well together by the means of your Storie and Muller, and put them into a pot; procure a clean Brufh that has been formerly ufed, and with it dipt in the Size pafs over all the piece very thin$1 y$, jobbing and ftriking the point of the pencil into the hollow places of the carved work, that no place, creek, or corner of your work may efcape the falutation; for every part of your Fraime or thing that hath not been partaker of the Gold-fize, or touched with it, is not in a condition to embrace or receive your Leaf-gold; fo that if care in this be wanting, your work, when it comes to be guilt, will be full of faults, and look fourvily: Having thus done, remove it to a convenient place for twenty four hours, free and fecure from duft; the longer it ftands, the better glofs your Gold or Silver will be adorned with, provided that it be tacky and clammy enough to hold your metals. Now to diftinguifh the true exact time when the Gold-fize is fit to be guilded, breath on it ; if your breath covers it over like a mift, tis evident that you may lay on your Gold; or otherwife, prefs your finger upon it fomervhat hard: ly; and if you perceive tis fo drie, that it will neither difcolout or ftick to your finger, but is in fome meafure claminy, tacky, and unwilling to part with it, conclude tis in a good condition : fhould you attempt to guild before the Size is dite enough, that moifture will drown and deprive your Gold of that glofs and luftre which it would acquire if skilfully performed; on the contrary, if the Size is over-drie, you are come too late, you have loft the opportunity, for it will not accept of the Gold. The firft mifcarriage of being too moift, is rectified by fuffering it to ftand one day fonger to drie; the latter, which is fo drie and fout, that it will not receive it, muft be confined to a damp cellar for a night, and then withoue queftion twill willingly accept of the golden Bribe:

$$
\text { Of laying on the Gold, and the Tools requitired for the bufinels. }
$$

You are defired in the firft place to furnifh your felf with a Cufhion made of Leather ftufft very even with Tow, and ftrained on a board Io inches one way, and I4 the other. On this you are to cut the gold and filver with a thin, broad, fharp, and fmoothedged knife: To thefe, three or four Pencils iof finer hair than ordinary ; fome are of Swans-quills; and fold fingly for 6d the Artifts ufe alfo the end of a Squirrels tail fpread abroad, and faftened to a flat pencil-ftick, which is broad at one end, and fplit, juft like an houfe-painter's Graining-tuol, but lefs; it ferves for tiking up and laying on whole. Leaves at a time, and is by them called a Pallet: Cotton is alfo requifite, and fome ufe nothing elfe. The Guilders:

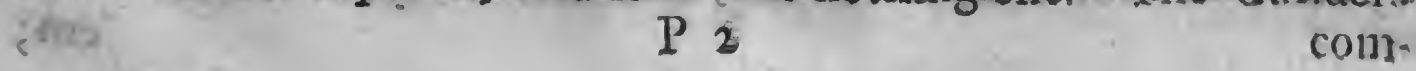


commonly border their Cufhion at one end, and four or five inches down each fide, with a ftrip of parchment two inches high, intending by this fence and bulwark to preferve their Gold from the affaults of Wind, and Air, which if moved never fo gently, carries away this light body, which willingly complies with its uncertain motions. Experienced Artifts frequently thake a whole book of Gold into this end of their Cuifhion at one time, and with their knife fingle out the Leaves carefully, and either firead them whole on their work, or divide and cut 'em, as the bignefs of the place requires: but I would not advife young beginners to prefume fo far, as to operate this way, but venture upon a leaf or two at once, cutting it as above directed. Next, handle your Pencil or Cotton, breathing on it, with which touch and take up the gold; lay it on the place you defigned it for, preffing it clofe with the faid Pencil or Cotton. Thus proceed, until the whole be finifhed and overlaid; then cut fome leaves into fmall pieces, which may cover feveral parts of the Frame that have efcaped guilding. Haviing laid it afide for a day, call for a large fine hogs-hair-brufh; with this jobb and beat over the work gently, that the gold may be preffed clofe, and compelled to retire into all the uneven, hollow parts of the Carving: Afterwards brufh all the Leaf-gold into a fheet of paper for fale. Laftly, with fine foft, Shammy leather, as it were polifh, and pafs it over. Thefe Rules being ftrictly obferved, your undertaking will be artificially concluded; 'twill appear with a dazling and unufual luftre, and its beauty will be fo durable, fo well fortified againft the injuries of wind and weather, that the attempts of many Ages will not be able to deface it.

\section{To Lacker in Oyl, fuch ibings as are 10 be expofed to tbe Weather.}

In this I requeft you to obferve the very method prefcribed before for guilding, with this difference, That your Primer be more white than the laft, which is effected by mixing a little White-lead, that has been grinded a long time, ainongtt the former Gold-fize; farther confidering, that your-Silver-fize ought not to be fo drie as that of Gold, when the leaves are to be laid on. Thefe two remarks being rightly obferved, go on with your defign in every particular as aforefaid, and you cannot poffibly mifcarry.

\section{To prepare and guild Carved Frames in Ogl, that are inot to be expofed}

Provide a pipkin, in it warm fome Size pretty hot; bruife with your hand, and put in as much Whiting as will only make it of the fame white colour. Size over your Frame once with it, then add more Whiting, until tis of a reafonable confftence and thicknefs: With this lay it over three or four times, as you find it ideferves, granting it time to drie fufficiently between every turn. Now take a fine Fifh-skin or Dutch-rufhes, and fmooth your Frame with

$$
\text { (1) }
$$


'em; when fo done, you may with a rag, or-finger dipt in water, finooth; or, which is the fame thing in other words, water-plain it to your mind; let it drie. After this, with a fnall quantity of Itrong Size, Cold-clear it; which is a term and name Aittifts mako ufe of in this cafe to exprefs themfelves by, but is no more then if I had faid in fhort, Size it oyer: when this is dried, Lacker over your piece by a gentle heat two feveral times. To conclude, lay on your Gold-fize, and perform every thing required in the foregoing inftructions.

\section{GHAP. XIX.}

\section{To overlay Wood with burnibi.Gold and Silver.}

N order to this work Parcliment-fize muft be provided, which is 1 made thus. Take two pounds of thic cuttings or flavings of clean Parchment; the Scriveners vend it for $3 \mathrm{~d}$. the pound: wafh and put it into a gallon of fair water, boil it to a Jelly, then ftrain, and fuffer it to cool, and you will find it a ftrong Size. This may be ufed in white Japan alfo; inftead of Ifing glafs-fize. When you intend to imploy any part of it about the bufinefs in hand, put a proportionable quantity into an earthen pipkin, make it very hot, remove it then from the fire, and fcrape into it as nuch Whitirg as may only colour it; mingle, and incorporate them well together with a clean Brufh. With this whiten your Frame, jobbing and ftriking your Brufh againff it, that the Whiting thay enter into every private corner and hollownefs of its carved work; give it
reft and leifure to dry. Melt Size again, and put in as much W.hiting now as will render it in fome degree thick, with it. Whiten over your Frame feven or eight times, or as you think beft, ftrik? ing your pencil as aforefaid, never forgetting this caution, to grant a through-drying time between every turn by the fire or Sun: but after the laft, before tis quite dry, dip a clean bruh in water, wet and fmooth it over gently, and rufh it fmooth when dry if you find it neceffary. In the next place, with an inftrument called a Gouge, no broader than a ftraw, open the veins of the Caryed work, which your Whiting has choakt and ftopt up. Laftly, procure a fine rag wetted, with which and your finger gently with care fmooth and water-plain it all over; and when tis dry, tis in a capacity to receive your gold-fize; of which in the following Para.
graph.

$$
\text { of Gold and Silver-jize for Burnibing. }
$$

Gold-fize is the chief ingredient, that is concerned in this fort of guilding, and tis a difficult task to find the true quantity of each diftinct thing that is required to make up the compofition; and the 
reafon of it is this, becaufe you are compelled to vary and alter the proportions, as each feafon changes its qualities of moifture and dryth ; for the Summer demands a ftronger Size than the Winter. The moft experienced are uncertain, when they make the Size, whether 'twill anfwer their intentions, and fuffer them to burnifh on it; therefore to know infallibly how 'twill endure, they lay fome of it on the corner of a Frame, and cover it with Gold or Silver; now if it does not burnifh well, but is rough, and inclined to fcratch; add more greafe or oyl, yet avoid too large a quantity. And feeing tis no eafie matter to hit right, and nick the due required mixture, I thall lay down feveral ways to make it, which I have not only experienced my felf, but are now practifed by fome. of the chief Profeflors of it in London.

\section{The best way to make Silver-fize}

Get in readinefs fine Tobacco-pipe-clay, grind it very fmall; if you pleafe, mix as much Lamblack as will turn it of a light afhcolour; add to thefe a finall bit of candle-greafe, grind 'em together extraordinarily fine, granting a mixture of lize aud water; then try it as before directed.

\section{The best Gold-grze now in ufe.}

Take of the beft Englifh and French Armoniack an equal quantity, grind them very finely on a Marble with water, then fcrape into it a little candle-greafe, incorporate and grind all well together. Again, mix a finall quantity of parchment-fize with a double proportion of water, and tis all concluded.

\section{Anotber size for Silver.}

Provide fine Tobacco-pipe-clay, grind a little black lead with it, caft in fome Caftile-foap, grind all of them together, mixing them with a weak Size, as we taught you in the laft account of making Silver-fize.

\section{A size for Gold or Silver.}

Take two drams of Sallet-oyl, one dram of white wax, put 'em into a clean gallipot, only diffolve them on the fire; to thefe, two drams of black Lead, and near a pound of Bole Armoniack, grind all very finely together, mixing with them alfo fize and water. Renember that I defire you never to grind more gold or filver-fize, than will ferve your prefent neceffities; if you tranfgrefs, and imagin 'twill be ufeful another time, believe me you'l be deceived when you come to make tryal: more ample and full directions experience will dictate to you; what follows, may be advantageous and inftructive in the preparation of your work. In order to goldfize it, If the fubject you are to work on be a carved. Frame, and you propofe guilding it, take yellow Oaker, grind it finely with water; add a little weak Size to bind it; when warm d, colour over your Frame, pafs by no part of it, permit it to dry leifurely. 
To Gold-fize your Frame.

Employ either of the former Gold-fizes, yet I am rather inclined to the firft; melt it, fo that it be only blood-warm, ftir it well with a fine brufh; as for its condition, let it be fomewhat thin. With this, fize over the Frame twice, but touch not the hollow places or deepeft parts of the Carving, where you cannot conveniently lay your Gold, for the yellow colour firft laid on is nearer in colour to the gold, fo that if in guilding you mifs any, the fault will not fo foon be difcovered. Allow it a drying fpace of four or five hours, and try if the gold will burnifh on it : if not, alter your gold-fize, and do it over again, and when dry, thus cover it with.

\section{To lay on Gold for Burnifbing}

Having fet your Frame on an Hafel, or fixt it in fome other place, in an upright pofture that the water may run off, and not fettle in any of the hollowneffes, lay fome leaves of Gold on your Cufhion, which you are to hold in your-left hand, with the Pallet and Pencil: alfo tis convenient to have a bafon of water at your feet; as likewife dry Whiting, to rub your knife with fome times, that the gold may not cling to it. All thefe being advantageounly placed, and in readinefs, advance forward, and after this manner fet upon the work. Produce then a Swans-quill-pencil, or a larger tool of Camels-hair if the work require it : this being dipt in ivater, wet fo much of your Frame as will take up three or four leaves, beginning at the lower end, afcending and guilding upwards, laying on whole leaves, or half, as your work calls for them, for your own intereft contriving how you may beftow 'em without wafte, which is the principal concernment a Guilder ought to be vigilant and circumfpect in; and that darling-metal, which we foolifh Mortals covet, nay almoft adore, is certainly too pretious to be lavifhly confumed and unprofitably puff'd away. Then wet fuch another part of your work, and lay on your gold, with your Pencil or Cotton preffing it gently and clofe. By thefe regular fteps and motions having guilded the two upright fides of your Frame, turn it, and proceed to operate after the fame man. ner by the remaining upper and under part. If your work be fuffi. ciently moift, you'l perceive how lovingly the gold will embrace it, hugging and clinging to it, like thofe infeparable friends, Iroin and the Loaditone. I enjoyn you, after the guilding of one fide with whole, or half leaves, or large pieces, as your work requires, to make a ftrict enquiry, and review thofe many little fpots and pla. ces, which, like fo many Errata, haye efeaped the Pencil, and may thus be regulated: Cut fome leaves of gold into finall pieces, and with a fmaller pencil than before wet the unguilded parts, and take up bits of gold proportion'd to the places that ftand in need of it; this laft peiformance we call, Faulting. Aif thefe things being done, let it ftand till to morrow that time; and no longer, for 
if you tranfgrefs, efpecially in the Summer, you'l find it will not burnifh kindly, or recompenfe your trouble by giving you ample fatisfaction:

To Burnifb your Work.

A dog's tooth was formerly lookt upon as the fitteft inftrumient for this bufinefs; but of late Aggats and Pebbles are more highly efteemed, being formed into the fame fliapes, for they not only. have a fine grain and greet, which conduces to, and heightens the luftre of the gold, but befides it makes a quicker difpatch, for by thefe means thofe narrow tedious ftroaks are prevented in this bur nifhing, and is performed with greater expedition. Thefe Pebbles. are each valued at 5 s. I do therefore prefer and recommend 'em before dogs-teeth. Having burnifht fo much of your work as you defign, leave the ground of your Carving untoucht, and fome other parts as you think beft, which being rough in refpect of the other, fets off and beautifies the burnifhing: that which is not burnifht, muft be matted or fecured with Size, Seed-Lac-varnifh; or Lacker, if you defire it deep-colour'd; and pray confine it to this part only, let not your unfteddy hand wander or tranfgrefs its bounds, and upon no account approach the burnifhing. Then the work muft be fet off or repoffed with Lacker, mixt in a gallipot with Dragons-blood and Saffron, or a colour called, Ornator; into which a fine pencil being dipt, with it touch the hollownefles of your Carving, the hollow veins of the leaves and foldage, if you imagin tis not deep enough, make it fo by a repetition; fome I know ufe Vermilion in Size, but I declare I am not reconciled to it, for tis not fo pleafant and agrecable to the cye.

$$
\text { To lay on Silver-fize. }
$$

Take Silver-fize that's newly ground and mixt with weak Size; warm it as your Gold-fize was, and with a clean pencil, of a bignefs fuitable to the work, fize oyer the fame once or twice. Let it dric, and if your Silver will burnifh on it, tis fufficient; but on the contrary, if it will not, we advife you to an alteration. Next, wet your work, lay on your Leaf-filver after the method for Gold directly, without any alteration, and burnifh it all over.

Now before we part with this fubject, I thall in brief lay down a few Rules to be obferved by all Practitioners. And

I. Let your Parchment-fize be fomewhat ftrong, and keep it no confiderable time by you; for 'twill not then be ferviceable.

2. Grind no more Gold or Silver-fize, than what may fupply your prefent neceffities.

3. Preferve your work clean and free from duft, before and af: ter tis gold-fized, and guilded, otherwife twill be full of fcratches in burnithing.

Laftly, never attempt to whiten, gold-fize, or burnifh it, in the time of a hard froft; for your Whiting will be apt to peel off, the 
Gold and Silver-fize will freez in laying on, not to fay any thing of other misfortunes that attend the unfeafonable operation.

G H A P. X X.

\section{To make good Pafle, fit to mould or rate Carved work on Frames for Guilding.}

I

Acknowledge this to be utterly ufelefs, on fuppofition thoto perfons who want Frames lived at London, on had any conve nient commerce with, and conveyance from, that Gity; becaufe Carved work is there done very cheap and well: but I confult the wants of thofe who cannot be fupplied from thence, or any other place where Artifts refide, who may afford 'em at reafonable rates. In this ftrait and exigency, therefore carve your Frames your felf, after this method. If you underftand, Modelling, or defire to make Models on which your Moulds thall be caft; take good, tough, well tempered Clay, and with your tools model and work out any fort of Carving which you fancie. lay it afide to drie in the fhade, for either fire or Sun will crack. 3t. When tis firmly dry and hard, and you intend to caft the Moulds on the Models, oyl your models over with Linfeed oyl; work the pafte briskly between your hands, clap it on, and prefs, it down clofe every where, that it may be a perfect mould in every part; and tis no fooner dried, than finifhed.

\section{To make Pafter}

Steep as much glew in water as will ferve you at prefent, then boil it in the faid liquor; make it ftronger than any fize, yet fomething weaker than common melted glew : bruife and mix whiting very well with it, until tis as thick and confiftent as pafte or dough; knead it very ftifly, wrapping it up in a double cloath, in which it may lie and receive fome heat from the fire; if you permit it to lie in the cold and harden, twill render it unferviceable.

To make a Mould of any Carved Frame, thereby to imitate it it Paffed

Take a piece of pafte more or lefs according to the length or largenefs of the leaves and flowers you take off; twould be idle and fruitlefs to take off the whole length, for you'l find one bunch of flowers, perhaps fix or eight times in one fide of a frame; fo that one mould may ferve all of that fort, provided they are artificially united and joined together. Work then the pafte between your hands, clap it on that part of the frame which, you defign to take. a mould off; let there be pafte enough, that the back of the mould. may be flat and even. While the mould is warm take it from the frame, and at the fame inftant with a weak glew fix it to at board that is larger than it felf. Thus may you take off any cther fmall 
fort of Carving, not only from the infide and edge, but any part of your frame, glewing all your moulds on little boards, and giving them leifure to drie and harden.

\section{Of placing Pafte or Carvedwork on Frames.}

Every Joyner can make frames for this purpofe, which fometimes are very plain mouldings, either half round, ojee or flat; for there may be fome little hollownefs and ojee, or what elfe you pleafe, allowed of, on the fides of the pafte-work. When your frames, pafte, and moulds are ready, dy the moulds very well with Linfeed-oyl, ftriking the brufh into every little corner, for this prevents the moulds fticking to the parte. Then ufe as much warm pafte as will fill up the mould, work it again between your hands, and whilft it is thus warm, and in good temper, put it into the mould, preffing all parts with your thumbs; next, with a knife cut off the fuperfluous pafte even withe the top of the mould : turn out your newly fafhion'd carved work on your hand, and before it cools glew it; and the place tis defign'd for, with thin glew; clap it on your work in the very place you intend it thall always ábide, preffing it gently. Then oyl your mould again, work your pafte, caft and place it as before: this muft be repeated, until the whole be accomplifhed, and the frame is to your content filled with carving. Grant it four or five days to dry in, after which time you may fafely whiten it. On thefe forrs of frames you may guild in oyl, or burnifh, but to the latter it is chiefly accommodated.

\section{CH A P. X XI. \\ Of LACKERING.}

Ackers are compofed feveral ways, and differ as varioully in $\mathcal{L}$ their value and goodnefs, which admits of degrees, according to the method and materials out of which they are produced; yet they have common to them all in which they univerfally agree, the famous ingredients, Spirit of Wine, and Seed or Lac-fhell-varnifh; but their Colour and Tincture for all this differ extreamly. Some boil their Lacker, whilft others (who are more in the right) are not beholding either to Fire or Sun. They who through ignorance diffolve it by fire, are in the firft place to be excufed, as alfo when they cannot rife to the price of good Spirits, ftrong enough to diffolve the Seed or Shell-lacc without fire; but becaufe fome may be willing to fave charges, and others defire indifferent Lacker. only, take along with you directions for them both. 
Tomake corrmon Lacker.

Take one quart of Spirit, put it into a Pottle-bottle; of Shella Lacc eight ounces, beaten fmall enough to enter the bottle; Thake 'em well together; having ftood till quite diffolved, ftrain it, and reduce to powder a fmall quantity of Sanguis Draconis, which with a little Turmerick tied up in a rag put into it, grant it a days continuance in that pofture, at your leifure hours fliking it. You may alter the colour, heighten or abate it, by adding or divinifling the quantity of the two latter ingredients.

\section{Another fort of Lacker.}

Ufe the fame quantity of Spirit of Wine and Shell-Lacc as be fore; when diffolved, ftrain it; but, to give it a tincture, inftead of common Dragons-blood and Turmerick, employ a very little. Sanguis Draconis in drops, and Saffron dried; which bruife, and cloath with a piece of linnen; and manage it as the other, by putting it into the veffel. If you defire the Lacker of a deeper or. more copperith colour, add more Sanguis; if the contrary, Saffron. Thefe being thakt well, keep clofe ftopt for your defigns.

\section{To make the beft fort of Lacker non ufed by the Guilders.}

Some ufe Shell-lacc-varnifh only for this Lacker, but Seed-laccis. much better, the compofition of which you are taught in the $8 \mathrm{th}$ page. Take therefore of this feed-lacc-varnifh, a quantity anfwerable to the Lacker, which give a tincture to after this manner. Take the colour called Ornator, ground and reduced to a very fine dry powder; mix it and fome of the varnifh in a gallipot, ftir and diffolve it over a gentle fire; after this confine ein to a viol clofely ftopt. Take likewife three or four ounces of Gambogium, which I would have bruifed, diffolved on the fire, and kept in a vial as the other. To a quart of this varnifh, if you pleafe, two penniworth of Saffron dried and bruifed may be added; to thefe, five or fix fpoonfuls of the Ornator, and a double portion of Gambogium-varnifh : being thaked well together, try it on a little bit of filver, or a fimall frame; if it appears too yellow, afford more from your Ornator, but if too red, from your Gambogium vial: by thefe contrivances you may continue the mixture until you arrive at the true golden colour, which is the only excellence we defign and aim at.

\section{To make a Lacker, that may be ufed without Fire or Sun.}

To a quart of the aforefaid Lacker allow 2 penniworth of $7 \mathrm{e}$ nice Turpentine; mix and incorporate them very well. With this you may lacker any thing in the open Air, and although it may

$$
R_{2} \text { look }
$$


64

The Art of Guilding, Lackering, \&c.

look dull and mifty immediately after every lackering, that fright, that feeming difcouragement, will quickly vanifh; that thin cloudy vapour, will be diffipated by its fudden, and piercing luftre.

\section{To lacker Oyl, Size, or Burnifbt Silverr.}

Let your Frame or work be warmed before you lacker it, and when fome of your Lacker is poured into a large Gallipot, with a fine large Brufh, that does not drop any of its hairs, made of Hogs or Camels-hair, be quick and pafs over the piece, carefully contriving to mifs no part, or to repafs another that has been already lackered; but in a manner obferve the fame rules here, that are given for Japan, yet with thefe exceptions in lackering Carved work; for then you muft be quick, and ftrike or jobb your brufh, thereby to cover the deep parts alfo: Be fure to lay it thin and even, and prefently warm it by the fire whilft it looks bright, for by thefe means you may lacker it again in a quarter of an hour, warming it. before and after the operation. If two or three varnifhings will. not produce a colour deep enough, oblige it with a fourth; but remember, if you thould carelefly do it too deep; all affiftance will be infignificant, and no remedy whatfoever will avail you.

To make Lackering foew like Burnifbo Gold.

If you are careful and neat in burnifhing your filver, and have graced your Lacker with a true gold-colour, have with an even hand laid it no thicker in one place than another; then Matt and Repoffe it, as you do burnifht gold; and unlefs narrowly furveyed, twill put a fallacy upon and deceive curious, difcerning eyes. Matting is only the ground-work of your Carving altered, or varnifhing it deeper and more dull than the other part of the Frame: Repoffing is done with Lacker and Ornator, (which latter the Drugfters fell at $4 \mathrm{~d}$ the ounce, ) with thefe mixt, touch and deepen all the hollow deep places and veins of your work; for it adorns and fets it off admirably well, by ite colour and reflection.

\section{C.H A P. XXII. \\ of Guilding Metals.}

T Acquainted you before with a controverfy betwcen the Guilders, concerning the Terms of Art, who denied the name of Guilding to that of Wood, and confined it to Metals only: upon which account we promifed you to treat of the latter too, and thereby comprehend both; although tis no queftion but one laies as juft a claim to that title as the other. They are certainly fine inventions, that ferve to pleafe us with the fhadow, when the fubftance 
The Art of Guilding, Lackering, Qce.

cant be purchafed: We are all of us great adinirers of Gold, and by confequence muift be enamoured with Guilding, which is fon nearly related to it. For Guilding is Gold in Miniature, with which as with a golden Ray, we beautify and adorn our viler Metals. It's preparation therefore niuft firft be difcovered, befere we can pioceed to the ufe and performance.

\section{To prepare Golds:}

Take Leaf, or fine Ducket-gold, which is niore excellent for this ufe, of either what quantity you pleafe; but be furc that the Ducket be beaten very thin : put the gold, and as much quick-filver as will juft cover it, into a gallipot. Let them ftand half an hour, prefently after the mixture ftirring them with a ftick. This time being expired, ftrain 'em through a piece of leather, fqueezing with your hand, till you have brought out as much quick-filver as will be forct through by all your induftry: Now that which remains in the leather looks more like filver. than gold, yet tis that, and that alone which muft be employed in the fucceeding
operation

\section{To guild Silver, Copper, Brafs, or Princes-metal.}

Whatfoever you defign for guilding, Thould be firft well fcrubbed with a Wier-brufh, fold by the Iron-mongers. Wet the piece with water or beer, and continue fcrubbing and wetting it, until all filth and dirtinefs be fetcht off, that the two metals may miore clofely hug and embrace each other. This being cleans'd, make ready quick-filver, by mixing it with a very finall quantity of Aqua fortis in a vial, which hould always ftand by you; three or four drops only of Aqua fortis, is fufficient $I$ affure you for an ounce of quick-filver. With this quicken your work, that is, with your finger or a fine rag rub this mixture on your metal, till tis all overfilvered or toucht with the faid quick-filver. This done, call for your gold formerly prepared, and with an iron-tool or little knife fit for the purpofe, fpread or overlay the whole work, being cares ful to mifs no part, under the penalty of doing that place over again, after you have given it an heat over a fire, which yout muft do when the gold is laid, to compel the Mercury or quick: filver to evaporate and flie away, leaving the gold fixed and adhering clofe to the piece. But before you give it a through heat, let it have two or three little heats, that you may with at hair-brufh, like that of a comb, dab and fpread your gold, which by the little warmth you gave it, makes the quickfilver alfo more ready to fpread. After thefe two or three vifits made to the fire, give it the thorough-heat at firft mentioned: then take it from the fire, and with a fcrub-brufh, that has never been toucht with quickfilver, clean it, as you did in the beginning. Now, if you perceive any fpot of quickfilver untoucht, you muift lay your gold upon it again: when tis cleaned with the fcratch-brufh, you may after this manner heighten its colour; if you think convenient. 
Take of Salt, Argal, and Brimftone, an equal quantity; mix them with as much fair water as will cover the thing when put into it; boil them over the fire, and having tied your guilded wort to a ftring, put it into the boiling liquor for a little fpace, tooking on it every minute, and when it has acquired a colour that pleafes you, dip it in cold water, and the whole is firifhed. But ftill if you would have the work more rich and lafting, you may again quicken it with quickfilver and aqua fortis, and guild it over igain after the former method, and repeat it fo often, if you pteafe, till your gold lies as thick as your nail upon the metal

$$
\text { Anotber way to guild Silver, Brajs, or Princes-metal. }
$$

Firft, brufh over your filven with Aqua fortis, then quicken your work with Mercury as before taught. Liet yourigold be beaten thin, and put into a Crucible, with juft fo mich quickfilver as will cover it, and let it ftand till it begin to blubber: then ftrain it through a piece of leather as before, and the quickfilver will go through and leave your gold, but difcoloured, aś hath been fiid; then lay it on with an iron-tool, and in-every thing do as you were taught in the other guilding.

$$
\text { Another way to beal, or beighten, the Colour of your Gold. }
$$

Take Sal Armoniack, Salt-petre, Sandiver, Verdigreece, white and green Vitriol, grind them with white-wine vinegar, which lay allover your work; then lay it on a fire,and give it a fimall heat that may make it fmoak, and then take it off and quench it in urive.

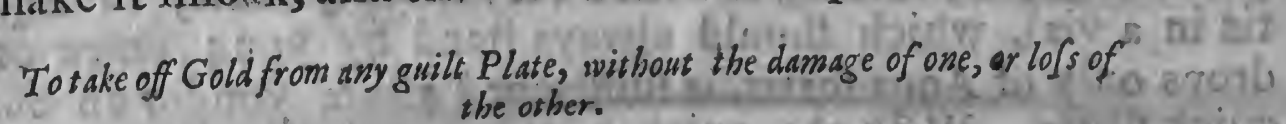

Put as much Sal Armoniack, finely beaten, into Aqua fortis, as will make it thick like a Pafte; fpread your Plate all over with it, put it into the fire, give it a thorough heat, neal it, or make it red hot; then quench it in fair water, and with a fcrub-brufh fcratch and fiub the Plate very well, which will fetch offall the gold into the water. After a little time ftanding quictly, pour off your water, and the gold will be to your fatisfaction found at the bottom; if all the gold be not come off, do the fame again. As for cleanfing this plate, or any other, which we call, Boiling of filver, firft, make your plate red hot, let it ftand till tis cold; then mix Argal and Salt with water, when it boils, put in your plate, keeping it there for a quarter of an hour: take it out, and when wafhed and rinfed in fair water, you'l perceive by its beauty that tis fufficiently changed.

To Silver-over Brassor Copper, as the Closkmaters do their Dial-jlates.

Having Leaf or burnt-filver in readinefs, put it into as much Aqua fortis as will cover it; after an hours ftanding pour off the Aqua fortis as clean as may be from the filver; wath the filver 
three or four times with water, det it drys and then thix it with one part of fine Argal to three of filver, with a little fair wator. When you make ufe of it, rub it on the iwork with a conk, until tis all filvered, and lie as fair as you could wilh. Next, dey it well with a linnen cloth, and having made it warm, wath it byer three or four times with the beft white varnifl, fpoken of hif this bookk, and it will not fail to fecure it from Tarnifhing, and other injuries:

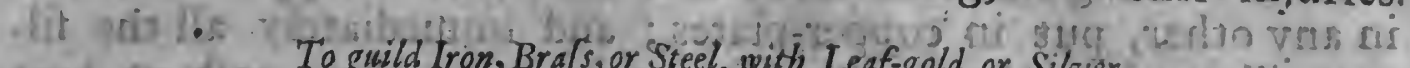

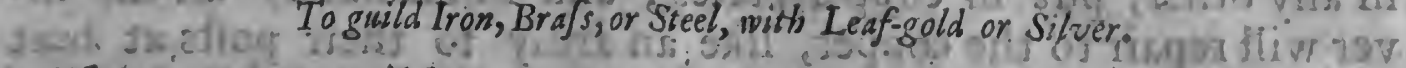

If you are to guild Brafs or old Jion, you muft cleanfe it very well with a Scratch-brufh, before you, itatch or guild wil it; biut for new I Iron or Steel, after you have filed it wery finooth, take

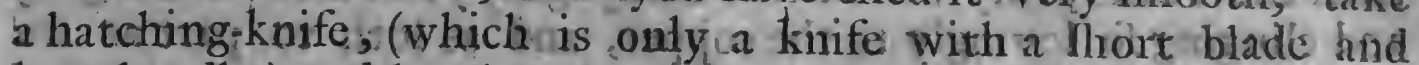
long handles) and hatch your work all over vieatly ; then gircitcin heat; whilft it looks blew, on n charcont fire, from iwheice itake it and layson your goldion filvier, and with a funguine ftone burnith it dowr a little; then give it the faine liwat and burnifh it all dover. Thus máy you repeat three or four, or half a dozen, or a dozen times if you pleafe, ftill obferving to give cit the faine heat before and after you lay on your gold or filver, and burnifh it. This leafgold and filver is much thicker than the other, and four times as dear.

\section{To refine Silver.}

Take Silver, be it never fo coarfe, and nelt it in a melting-pot; then caft it into water, to make it hollow; after tis cold take it out and dry it, mixing one ounce of Salt-petre to a penni-weight of Antimony, (fo proportionably greater quantities, if you have occafion.) Thefe with your Silver confine again to a melting-pot, covering that with another, very clofely luting them together with loani, made of clay and horfe-dung. The two pots being thus ceimented, put 'em into the fire, and give them a very ftrong heat, after which remove theni to a cooling place. Break the pot when cold, and you'l perceive the filver fine at the bottom, but the fcorio and drofs on the upper part like a cinder. Copper may be feparated from Gold after the fame manner.

\section{To Separate Gold and silver, when incorporated, with Aqua fortis.}

Take as much Aqua fortis duplex, as will fomething more than cover your metal, in a ftrong vial or parting-glafs. Put it on fand over a gentle fire at firft, with the glafs. open and unftopt; for if tis clofed twill break in pieces, as may alfo a fierce fire at the beginning: by degrees therefore increafe its heat, till you make the Aqua fortis fimper and boil ; continue fo doing, till your metal be diffolved. This done, pour the Aqua fortis gently into water; the filver will invifibly go along with it, but the gold remain at the bottom of the glafs; which gold, when well wafhed with $\mathrm{S}_{2}$ water, 
water, you may melt down, or preferve for guilding metals, by mixing it with quickfilver, and ftraining the latter through leather, as you were inftructed by Leaf and Ducket-gold.

Now to reduce the filver into its former body which appears to be a water, and fo would remain many years, unlefs you take this method for its alteration; pour the faid water (wherein your filver is floating like undifcernable Atoms) into a copper veffel, if in any other, put in copper-plates; and immediately all the filver will repair to the copper, like an army to their pofts at beat of druin, fo that in two or three hours time (that finall parcel of filver, which hath been feparated into parts more innumerable than the Turks army will be this Campagne) you'l find all hanging and clinging fo lovingly to the copper, and as loth to part as we from our Miftreffes, tho they're fometimes more unconftant to us than the filver is to the copper, for no other metal can tempt it to the fame compliance. The fame filver fo gathered you may ufe for filvering any metal, doing with it as is here taught of the gold, or inftead of leaf or burnt filver diffolved in Aqua fortis, as was before faid in Clockmakers filvering.

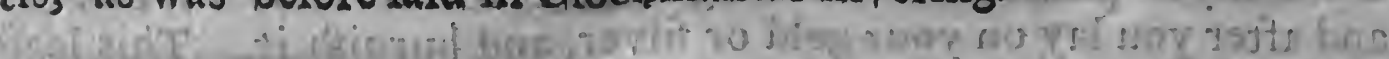

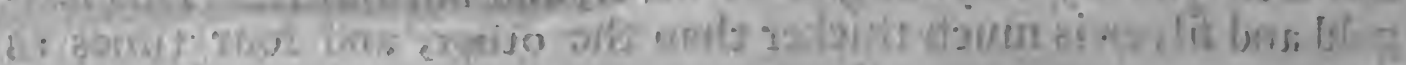

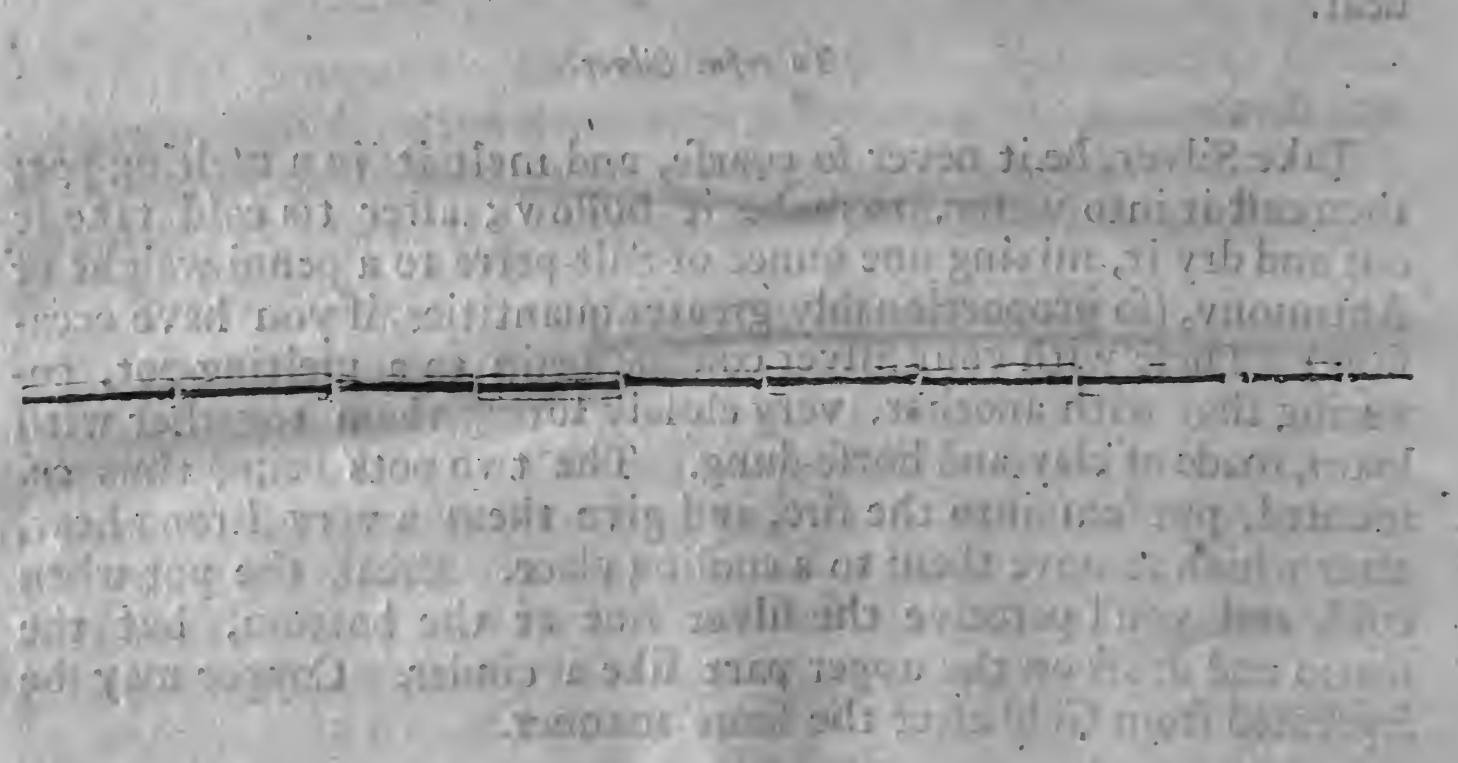

C H A P.

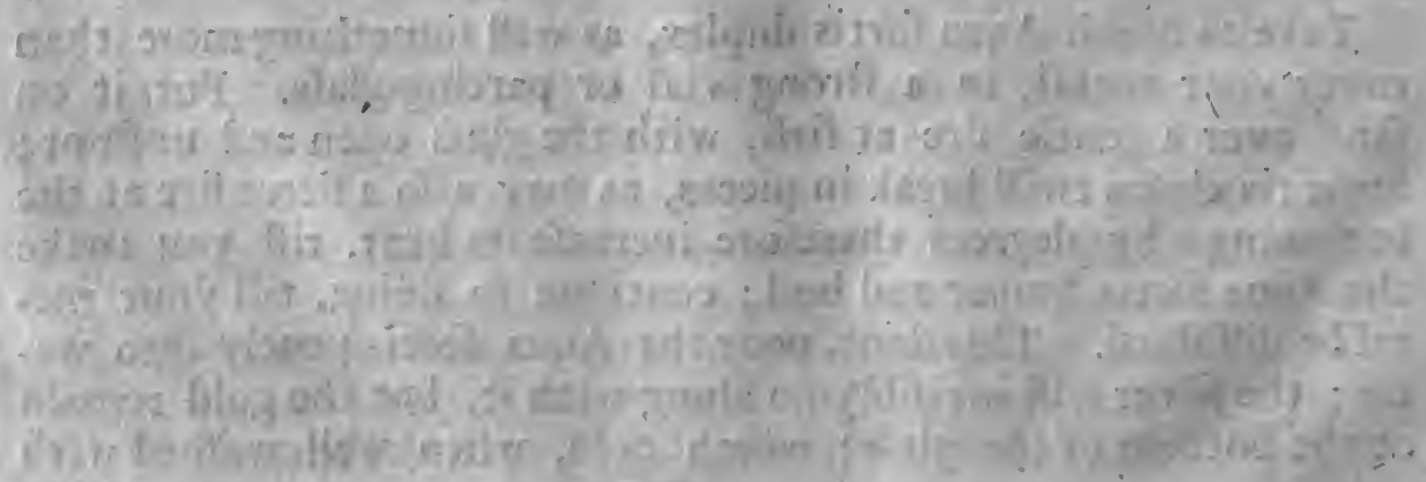




\section{Directions in Painting MEZZOTINTO-PR IN Ts; on Glaß, or witbout it.}

\section{CH A P: X X I I I.}

$\mathrm{T}$

His moft ingenious way of Painting juftly claims applaufe and admiration, if skill and dexterity are called to the performance: Where thefe two combine; beauty and perfection muft danceattendance: Tis a pleafant, infinuating Art; which, under a pretty difguife betrays us into a miftake: We think a piece of Limning lies before us, bur more ftrict enquiries will evince, that tis Mezzo tinto at the bottom; Who can be difpleafed to be fo innocently deluded, and enamoured at the fame time? Tis female policy at once to ravin and deceive the eyes, and we not only carefs the cheat, but are in love with the impoftor too. This manner of Painting is lookt upon to be the Womens more peculiar province, and the Ladies are almoft the only preteriders; yet with modefty and fubmiffion I may adventure to affirm, that I have not had the good fortune to meet with one of an hundred, that hid an excellent command of the Pencil, or could defervedly be ftiled a Miftrefs of this Art; yet tis certainly ilo uneafie task to arrive to a great height in it: but we are overftockt with no lefs conceited than ignorant Teachers, well qualified to deface a Print, and fooil the colours, who abufe thofe young Ladies that defire inftructions, perfwading 'em to the damage of their purfes, and lofs of their time to attempt that which they are not able fo much as to affift 'em in. This is a fufficient inducement to perfwade ny felf, that thefe Rules will be acceptable; tho I know very well that I have raifed a difcourfe on a fubject with which the world is very well acquainted, yet by way of requital I thall make greater difcoveries thain the famous Miftrefs of it ever pretended to communicate; in a word, I promife to difplay it in its perfection.

I conceive tis requifite to advife you, firft, in the election of Prints, Frames, and Glafs; of each in their order. Mezzo-tinto Prints are to be preferred before all others, being iiore fit and fuitable for Painting than thofe that are engraved, for in thefe all the Atroaks of the Graver are plainly vifible; but the other, if done with a neat and careful hand, on a good, fine-grounded piint, cant hardly be diftinguifht from Limning. Confider, that fonie of thefe Prints are of a coarfe ground, others of a fine: the firft are difcernible, for they feem to be rough, and workt as it were with the pricks of a Pen; but the latter hath foft and fine thadow's, like at piece neatly wrought in Indian ink, or a picture in black and white. 
Obferve farther what paper they are drawn upon; for if it be too thick, which you may forefee by wetting a corner of it with water or your tongue, and it pafs not through the paper prefently, then conclude tis not for your purpofe; but on the contrary, the thin and fpungy paper muft be elected: Their value is enhanced by the different fize and goodnefs of each Print ; fome may be afforded for fix pence or a fhilling, others for $18 \mathrm{~d}$. or more.

Your Glafs ought to be thin, white, and well polifht, fuch as is made for Looking-glaffes. All blewifh, red, green, ańd windowglafs, cannot be allowed of here, you muft altogether defpife and carhier it; for if you paint on either of thefe, efpecially windowglafs, your colours can never appear fair and beautiful.

Your Frames for glafs-painting are utfually made of ftained Peartree, with narrow mouldings for little pieces, which increafe in bredth, as the fize of your picture does in largenefs; they are made with Rabets, and are afforded for 6,8 , and I2 pence, or more, according to their feveral dimenfions.

Another fort of Erames I recommend to youl, moft proper for thofe Prints which you paint without glafs, called Strainingframes: If you defire to have them Caryed, Guilded, or black, order them to be made flat, and even, without a Rabet on the backfide, half an inch lefs than the edge of the Cutt, every way; which is apt to rend when it undergoes the trial of ftraining. This inifchance is occafioned by the thatp edge of the Plate, which almoft cuts the paper when tis printed: If you approye of black Frames, command the Frame-maker to work them half round with Peartree; would you ftain, or Japan them, guild or raife their carved work; this Book will fufficiently inform and direct you. Thus much of thefe things in particular; I thall now proceed to give a catalogue of fuch Colours as may be affiftant to you in this bufinefs, together with the Oyls, and their feveral prices; as alfo directions to make drying Oyl, and various forts of Varnifh for Painting. And firt, the names of your colours, and their value, as they are commonly fold ready prepared, take in the very order that they are placed on your Pallet.

Flake White, finely ground in Nut-oyl, is fold at 2s. the pound. White-lead, ground in the fame oyl, Is. per pound.

Yellow and brown Oaker, finely ground in Linfeed oyl, is vended for 3 d. the ounce.

Yellow or Dutch Pink may be afforded, when ground, at the fame rate.

Brown or glafing-Pink is indeed very dear, the bignefs of a Nutmeg grinded will ftand you in $6 \mathrm{~d}$.

Fine Lake will coft as muich.

Light and brown Red, are only yellow and brown Oaker burnt; tis 3 d. the ounce ready ground.

Italian Terravert, is not much ufed in this Painting, though very much in all others; tis dearer fometimes than at others.

Umber 
Unber, Collins-Earth, Ivory, bleiw black, are afforded at the or: dinary price when ground, which is $3 \mathrm{~d}$. the ounce:

Diftilled Verdegreas ground, you may have at the fame fate with Brown Pink and Lake; but thefe three colours I would ad: vife you to purchafe by the Ounce, and grind em your felf, if it will ftand with your conveniency; for the Colour-Grocers will af: ford thefe cheaper by the Ounce than Dram. Its price is Is. the Ounce; indifferent brown Pink, and Lake, for the fame value; but that which is more pure and fine, is Is. $6 \mathrm{~d}$. $2 \mathrm{~s}$. and $2 \mathrm{~s}$. $6 \mathrm{~d}$. or more, as they excell in goodners:

Some Colours are in powder, which you sunf of neceffity have by you, and thould mix and temper on your Pallet, as you thall have occafion to ufe them.

The firft is Vermilion, ufually fold at yd the Ounce.

Carramine, being the fineft and moft excellent Red, is fometimes vended for 31 . the Ounce.

For Blews, the beft fine Smalt is to be bought for 4 or 5 s: the pound.

Blew Bife, ufeful only in making green colours, may be gotten for 4 d. or $6 \mathrm{~d}$. an Ounce.

Ultramarine, the richeft blew in the world, bears feveral prices : the deepeft and beft will coft 6 or 7 Guinea s, bat then it muft be extraordinary fine; other forts are expofed for 3 or 41 . the Ounce, which is very good too, and fit for this ufe; fome again for 20 . the fame quantity, and may ferve for Painting, but tis too coarfe for glazing.

Yellow and pale Mafticott, which is fineft, free from greet, with the brighteft colour, is the beft. If it prove coarfe, grind or walh it a little on a clean ftone; tis fold for $2 \mathrm{~d}$. the Ounce.

Red Orpiment you muft mix with drying Oyl; this too is af: forded for $i d$. the Ourice.

'Thefe are the Colours ufeful in Painting, with which you ina' exactly imitate and hit any colour whatfoever, by different ways and methods of mixture. Their price alfo I have given you, if you buy them in fmall parcels; but if you furnifh your felf with greater quiantities at one time, you'l find the purchafe more cheap, and eafie. Obferve, that fix of thefe are tranfparent or glazing colours, viz. Brown Pink, fine Lake, Carramine, fine Smalt, Ul: tramarine, and Diftilled Verdegreas:

\section{To wafh, or make any of the Powder-colonrs very fine.}

You inuft have four or five large Wine-glaffes by you, and two or three quarts of clear water. Fill one of your ghafles with it ; put in half an Ounce, or as much of your colour as you intend to wafh ; ftir it well about with your knife, permit it to ftand no longer than while you could count or tell forty; for in this thort fpace of time all the coarfe will fink and fettle to the bottom, the finer 
finer remains floating in the water, which convey and pour off in: to another glafs, leaving the coarfe part behind. Let the veffel; with the fine colour and water, ftand till next day, by which time that alfo will fettle to the bottom of the water. This being pourcd off, take out the colour; place it on a clean fmooth Chalk: ftone, to loak and drink up the water; and when tis dry, paper it up for your bufinefs.

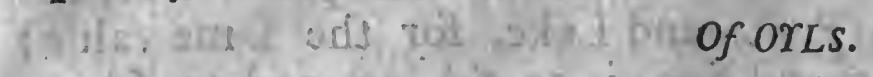

It remains, that to this account of Colours, we fubjoyn that of Oyls, which muft be ferviceable to us in the Art of Painting.

The firft of thefe is Linfeed Oyl, fold at 8d. the quart.

Nut-Oyl, to be purchafed at I6 or I8d. the like quantity.

Oyl of Turpentine is afforded for lefs than $8 \mathrm{~d}$. the pound.

Drying-Oyl, will ftand you in $2 \mathrm{~d}$. an Ounce at the Colour-fhops, and Fine-varnifh $3 \mathrm{~d}$. which in my opinion is too dear; and therefore, if you'l give your felf the trotible, I'le be at the pains to inftruct you, how to make either fort.

\section{To make the hest Drying-Oyl.}

Mix a little Letharge of Gold with Linfeed-Oyl, for a quarter of an hour boil it; if you'd have it ftronger, continue boiling it, but not too much neither, left it prove over-thick and unferviceable.

Bruife Umber and Red-lead to powder, mix 'em with Linfeedoyl, and for boiling follow the directions foregoing. When this Oyl has ftood a day or two, and you find a skin over it, know then for certain tis at your fervice.

To make Varnifbes for the e Prints, or Pictures in oyl.

Put an Ounce of Venice-Turpentine into an earthen pot, place it over a fire, and when diffolved and melted thin, add to it two ounces of oyl of Turpentine; as foon as they boil take off the pot, and when the varnifh is cool, keep it in a glafs-bottle. This and all other varnifhes ought to be ftopt clofe, and fecured from the approaches and damage of the Air. With this you may varnifh your Prints on glafs or others, to render them tranfparent; this is what the Shops fell for fine varnifh : fhould your varnifh be too thick, relieve it by an addition of Oyl of Turpentine.

$$
\begin{gathered}
\text { Another more excellent Viarnib either for Pictures in oyl, or making Prints } \\
\text { transparent. }
\end{gathered}
$$

Inclofe fix ounces of the cleareft, white; well-pickt Maftick finely powdered, in a bottle with fixteen ounces of oyl of Turpentine; ftop and fhake them well together, till they are incorporated. Then hang the bottle in a veffel of water, but not fo deep as to touch the botom; boil the water for half an hour, in which fpace you muft 
take it ou three or four times to thake it $;$ if you d have it ftronger, boil it a quarter of an hour more. I could give you a greaternumber of Recipe's; but 'twill be too irkfome, tediouss, and unne. ceffary, feeing thefe will preferve your pictures, and are as good in their kind as any Varnifhes whatfoever.

\section{CHAP. XXIV. Io lay Prints on Glaß.}

HAving at large treated of the Colours, Oyls, and other materiH als required in this work; I proceed to inftruct you how the Prints themfelves muft be laid on Gläfs Firft therefore let your Prints be fteeped in warm water flat:ivays, for four or five hours, or more, if the paper be thick: provide then a thin pliable knife, with it fpread Venice-Turpentine thin and even over the glafs, and with your finger dab and touch it all over, that the Turpentine may appear rough. Next, take the Print out of the water, lay it on a clean Napkin very evenly, and with another prefs every part of it lightly, to fuck and drink up the water of it; afterwards lay the print on the glafs by degrees, beginning at one end, ftroaking outwards that part which is faftning to the glafs, that between it and the Print no wind or water may lurk and hide it felf, whicli you muif be careful of, and never fail to ftroke out. Then wet the backfide of the print, and with a bit of fpunge or your finger rub it over lightly, and the paper will role off by degrees; but be careful, and avoid rubbing holes, efpecially in the lights, which are moft tender: and when you have peeled it fo long, that the Print appears tranfparent on the backfide, let it dry for two hours; next, varnifh it over with Maftick or Turpentine-varnifh four or five times; or fo often, till you may clearly fee through it. After $a$ nights time for drying, you may work on it.

\section{To lay Prints, either graved, or Mezzo-tinto's, in fuch manner, that you may
role off all the paper, and leave the foadow beliind.}

Soak the Print in water, dry it with a cloath, fpread on the glafs oyl of Maftick: and fome Turpentine, and lay on the print upon it, exactly as before. When tis almoft dry, brufh off the paper with a brufh; and you'l find none but the inky, fhadowed part remain : then do this as the former with Maftick-varnifh, which prefervedry and free from duft, until you are at leifure to paint upon it.

To prepare Prints without glafs or firaining-frames.

When your prints are fteeped fufficiently in water, lay them on a finooth, wet Table, with the print-fide downwards, and rub ein thin as before for glafs. Next, with common pafte, do the backfide of your frame; and pafte on your print while wet: give it lei- 
fure to dry, and then varnifh it on both fides four or five times with Maftick or Turpentine-varnifh, until tis fo tranfparent, that you may fee the Picture as plain on the back as forefide: Laftly; allow it a day or two for drying.

\section{Of the poffure and pofition of the Prints, and thofe that paint them.}

I may now very reafonably fuppofe, that all things are in readinefs, and that nothing may hinder us from fetting about the work in earneft. Moft Ladies that have practifed this Art have made ufe of an uneafie pofture for themfelves, and a difadvantagious fituation for their piece : for they generally ftand to it when the windows are high, againft which they place the Print; but whofoever ftands, cannot fo fteddily move the hand and pencil as the perfon that fits down. I advife you therefore to a Table Hafel, very like to, and not improperly called, a Reading-desk; only with this difference, That where the Panel or back-board for the book is; there our Painting-desk may be all open, with three or four wiers pendant-wife, to keep the picture from falling through, and a narrow ledge at the bottom to fupport it. Befide thefe, I would have little holes made equally diftant on both fides of the Desk, as tis remarkable in Painters Hafels, that by pegs or pins, and a narrow ledge laid upon thein, I may raife my Pieture higher or lower, as it beft fuits with my conveniency. Being thus fixt, lay a fheet of very white paper behind the picture on the table, and you'l find it mich better, and more conveniently placed than againft the window.

\section{How to paint a Meza-tinto-Landskip on Glass, or otherwife.}

The firf thing to be attempted in this work, whether Landskip or others, is Glazing all thofe places that require it; and if you defire they fhould lie thin, and drie quickly, (as they ought to do, ) mix varnifh when you lay them on, and in four hours time they'l be ready for the reception of other colours. In Landskip, you fhould firft glaze the neareft and great trees, and ground 'em with brown Pink, or, if you fancie them greener, add diftilled Verdegreas. The trees, that are to appear with a lively, beautiful green, as alfo the leaves and weeds, that are in fome pictures, muft be glazed with Dutch-Pink, and diftilld Vexdegreas; the trees farther off, with Verdegrens alone; the hills, mountains, and trees, at the greateft diftance of all, remember to glaze with fine Sinalt, a little Lake, and Verdegreas, all thinly mixt with varinih. As for the Skie, although feveral Miftreffes practife and teach the cutting of it out from the picture, and painting it on the glafs, I do: by no means allow of it, for it agrees not with the eyc, but inakes that part which fhould feem more diftant, appear too nigh and before the reft; in a word, it fpoils and difparages the whole piece. I cannot fuggeft to my: felf any seafon for this foolifh contrivance, unlets 


\section{Mazzo-tinto. Prints.}

fenfe of their inabilities to paint em beautifully, obliges them to commit fo great an abfurdity. Take then Ultramarine; or, for want of that, fine Smalt; mix it thin with varnifh, and glaze it over two or three times with a clean large Pencil, and a very fwift ftroak ; for if you're tedious, it will dry fo faft, that you cannot poffibly lay it even. If the Landskip be adorned with Figures, Buildings, Rocks, Ruins, or the like, they require finifhing firft of all. The mixture of colours for thefe things confifts chiefly of white, black, and yellow, fometimes a tincture of red; but the management and compofition of them I leave to your inclinations fancy, and experience : yet I would have you confider, that all your. Colours for this fort of Painting ought to be extraordinary light. Now to finifh the Trees, Ground, and Sky, and the reft of the picture, begin as before with the greateft or neareft trees, and with yellow Pinke and white, paint over the lighteft leaves; but with a darker colour of Pink, and a little Smalt, do neatly over the darkeft and outward leaves with a fmall pencil dipt in varnith. Thofo trees you twould have beautiful, paint with a mixture of yellow Mafticott, Verdegreas, and white; the darker parts with Pink; Verdegreas, and white; as thofe trees alfo which you glazed with Verdegreas only, they being mixt very light with white. But to finith the skie and foreskip; if any clouds appear, touch then with varnilh and light colour, made of white, yellow Oaker, and Lake: With thefe likewife touch the lighteft parts of hills, and towns, at the remoteft diftance; then mix Smalt and White as light as you can conveniently,and paint over the skie; add to thefe a tincture of Lake, and do over the darker clouds : Let your colours lie thin, and even; if the whole be finifhed, grant it time to drie in. If you would have your Picture look more ftrong, brisk, and lively, fet it againft the light, or on the Hafel as before; and although tis painted all over, you may perceive the fhadows and lights through it; if not, what you painted before will guide you. Paint then your skie and forefight with the fame but lighter colours than before, and fo every thing elfe refpectively:

\section{H A P. XXV.}

\section{To Paint a piece of fgures, as Men; itomen, $\sigma c$.}

I painting a Face, the firft thing required is, if there are any deep thadows, to glaze and touch them thinly with Lake, brown. Pink, and Varnifh; alfo the white fpeck and black ball, or fight of the eye, as the Print will direct you; the round white ball of $a$ convenient colour too. If you make the lips of a delicate red, glaze them with Carramine, or Lake: For the reft of the face, begin with the dark fides and paint the thadows with a colour mare 
red than ordinary, for which Vermilion, yellow Pink, and white, are moft proper; where note, that all varnifh is forbid in painting fiefh-colours, except what is ufed in glazing the fhadows : if you fhould mix varnifh, the inconvenience will be, that the colours will drie fo faft, that you cannot fiveeten the hadows with the fleftr. Then give fome touches on the ftrongeft lights of the face, as the top of the nofe, forehead, and by the eyes, mouth, and chin, with a colour made of white, pale Mafticott, or yellow Oaker; and a little verinilion, and mixed according to the complexion intended; then mix that colour a thought darker, and lay it on all the face, that was not painted before, very carefully ; yet for the mouth, and cheeks, fomewhat redder. Next, with a fine clean pencil, that has been ufed and worn a little, hatch and fweeten all. your-fefh-colours and fhadows fweetly together; cleanfing the pencil as often as tis requifite. Cheeks too pale, or any other part., may be regulated with fuitable colours, whilft the picce is moift and wet. For fwarthy complexions, mix the flefh-colour with white, yellow or brown Oaker, and light red, with fhadows agreeable. I requeft you to obferve the fame method in painting breafts, hands, or naked bodies, as for the face : When any of thefe are drie, you may go over them again, by which fecond painting you may effectually mix your colours to your humor. Laftly, be ever careful, that your pencil be fteddily guided, without the leaft flip or: trefpass upon lines and features of a difagreeing colour.

\section{To P dint Hair.}

Tis not convenient in this Painting to ufe Varnifli or Colours neer fo dark as the life, for the Print will darken it: as for example; Suppofe I were to paint an head of hair that is black, I would mix white, black, red Oaker, with a touch of Lake or light red; all which may produce an afh-colour; and the hair or Peruke being coloured with it, will reprefent a natural black. Now to make the curles fhew ftronger, touch the lighteft parts with a lighter colour, and the darkeft with the contrary; all which you may fee through, if they are not laid too thick.

\section{To paint Drapery or Garments.}

To paint a piece of Drapery or Cloath, of a broken colour, you muft take care of its mixture; yet you are to make three degrees of the faid colour, that is one, the very colour, another more light, the third darker :- this laft is for the darkeft folds, the lighteft for the lighteft pleats, and the colour between both for the other part of the garment; fiveeten the colour with i. worn pencil, that the folds may not lie hard. If you have a mind to embroider a garment, make fringe, or any other parts with flrell or powdered Gold or Siver, mix then your metals with gum-water, and with a i... 


\section{Mezzotinto Prints.}

fine pencil hatch or embroider your flowers, and touch the fringes, or what elfe beft pleafes you, before you either' glize or paint the garment you defign to adorn, after this manner.

How to pairit changeable Drapery.

Imagine that your garment to be painted had its ground purple; and the lights yellow; take then a fine pencil dipt in varnifh, and with yellow Mafticott touch thinly all the lighteft parts of your folds; if there be occafion repeat it, for your colour muft be very thin with varnifh: when drie, glaze it all over with Lake and Ultramarine, or Simalt with varnifh once or twice, and let it drie; then mix three degrees of a purple colour, one of Lake, Smalt, and White, and lay them on, as the laft Paragraph directs you:

\section{To paint feveral forts of Red Drapery; and, firft, of the Fineft.}

Take Carramine, and mix it thin with varnifh alone; glaze over your garment once, if you d have it very beautiful, two hours after do the fame again; and when that is drie; with vermilion and white, or vermilion only, you may paint all cxcept the dark fhadows, which thould have red. If you can fee through the colour when drie, the lighteft folds, touch them over with clear white, and they will appear more rich and ornamental.

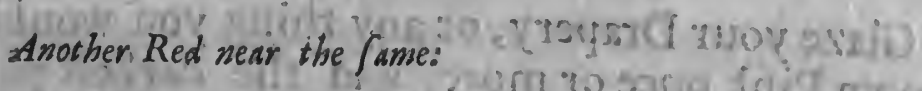

Grind Lake very finely in oyl, temper it well with drying oyl and varnifh; with this glaze over your Druperyotwo or three times, and when tis dry, paint the lighteft with iwhite, the darkeft with light or brown red, the remainder with veriuilion. of til s $2 \mathrm{As}$

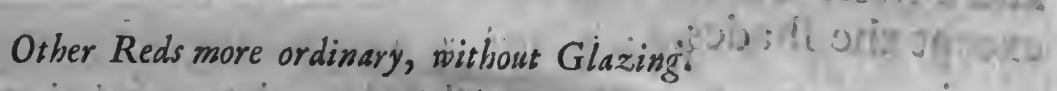

Mix vermilion and white, and paint the ftrongent lights with it the dark fhadows with a light or dark red, and the reft with vermilion. For the lighteft folds, mix light red and white; for the dark pleats, brown red; for the reft, light red only:

To paint the beft Blew, and glaze with Uliramarine.

Mix Ultramarine with thick Nut-oyl; but if you cannot wait and attend its drying two or three days, then inftead of oyl ufe varnifh, and glaze your garment three or four times over, letting it dry between every turn; when tis dried, make three degrees of Smalt and White very light, and with the cledreft white do the lighteft folds, and the reft as directed in the other colours. If you are unwilling to beftow Ultramárine upon it, you may after the fame method glaze with fine Smalt, and varnifh it as often as with the former, and paint it with White and Smalt: An indifferent Blew is made with White and Smalt, mixt in feveral degrees without glazing. 


\section{Directions in Painting}

\section{To glaze and paint the beft Parple-Drapery.}

Glaze the garments thin, once over with Carramine, or Lake; when tis dry, paint it every where with Smalt and White, lighter or darker as you think beft, but let the lighteft folds have ftill a. colour more light than the reft. Contrary to this you inay produce a purple, by glazing your work over once or twice with UItramarine, or Smalt, and paint it with Lake and White.

\section{Purple without glazing.}

Make a mixture of Lake, Smalt, and White, with which paint the Drapery, heightning and darkening the folds as in the other Receipts.

\section{Tellow Drapery.}

For your lighteft folds, mingle yellow Oaker, and White; and brown Oaker for the thades: if that is not dark enough, Umber will make it fo; but do over the other pleats with yellow Oaker. Such another colour may be made with White, yellow and brown Pink.

To paint the moft beautiful rellow.

Glaze your Drapery, or any thing you would have lovely, with brown Pink once or more; and the darkeft parts oftner; after tis dried, touch the lighteft folds with pale Mafticott, the next with yellow Mafticott: if fome require a colour darker than that, mix yellow or brown Pink; but for the faddeft of all, ufe yellow Pink and a little Umber. When tis drie; you may paint all with white, except the thades.

To finifb, varnifb. and polifb Pictures, that are not laid upon Glass.

There defire the fame proceedings with thofe on Glafs, unlefs you have a mind to adorn Embroidery, Fringe, or the like, with Gold or Silver. Touch then the forfide of your picture with fhell-gold in gum-water; or elfe, after you have varnifht it two or three times with varnilh made of Spirit, take Japan gold-fize, with which hatch and lay it over with gold-duft; and if your judgment and experience will allow of it, you may touch and heighten all the frongeft lights, and deepen your fhadows too on the forefide, which gives fo much life to it, that Limners themfelves have been deceived, and miftook it for a piece of real painting. I defire young beginners to forbear, and not attempt this way of finithing, till experience and practice fhall give them incouragement. If you defign to varnifh and polifh any of thefe Prints; lay on the colours without skins, and very even on the backfide, and permit them to drie' at leaft a week (for the longer the better) before you offer to varnifh them after this following manner. 


\section{Mezzo-Tinto-P̈rintso}

To varnifb the e Prints, or other Pictures, without polifbing.

Take of the beft white Japan-varnifh, and an equal quantity of Varnifh made of Maftick and oyl of Turpentine ; into thefe ming led together, dip a fine Camels-hair-brufh, and with it varnifh over your piece, four or five times carefully by the fire, as you. are taught to do Japan; and you'l find that it gives a very rich glofs.

\section{Tovarnils pidtures; and polif̣ them, like Fapais}

With white-Japan-varnifh only wafh over your work five or fix times, obferving all the method for Japan directly. When it has refted three or four days, lay the Picture on the Cufhion, whereon you cut the Leaf-gold: then with Tripole and water polifh it; and laftly, clear it up as you do White-Japan.

Thefe are the Rules in fhort, I thought fit to lay down in the treatife of this pretty Art; and I queftion not but they are full, moft exact, and fatisfactory, and will be found fo, when the Ingenious Ladies thall put them into practice.

\section{To Imitate and counterfeit}

\section{TOR TOISE-SHELL and MAR B LE.}

\section{H A P. X X V I.}

$\mathrm{B}$ Efore Japan was made in England, the imitation of Tortoifethell was much in requeft, for Cabinets, Tables, and the like but we being greedy of Novelty, made thefe give way to modern Inventions: not, but that tis ftill in vogue, and fancied by many, for Glafs-frames, and fmall Boxes; nay, Houfe-Painters have of late frequently endeavoured it, for Battens, and Mouldings of Rooms; but I muft of neceffity fay, with fuch ill fuccefs, that I have not to the beft of my remembrance met with any that have humour'd the Shell fo far, as to make it look either natural, or delightful. But, to avoid all reflections, I muft attribute this to that miftaken piece of frugality in them, who think, if they can agree with a Painter by the greatt, their bufinefs is done; for by: 
thefe means, they not allowing the Artift a Living price, he cainnot fpend both his oyl and labour, nor ftretch his performances to the utmoft extent of his skill. On the other hand, fome there be who are indeed willing, but not being Mafters of what they profefs, fink and come fhort through their inabilities. I believe the complaint is univerfal; the ingenious and moft excellent in each profeffion, being deftitute of a reward that is anfwerable and proportioned to the worthinefs of his undertaking.

But tis high time that we clofe with the bufinefs in hand. And firft, the Tortoife-fhell,I propofe for your imitation, is that which is laid upon Silver-Foil, and is always made ufe of for Cabinets and Boxes, for it gives life and beauty to the Shell, which elfe would appear dull and heavy. Now to counterfeit this very well; your wood ought to be clofe-grain'd, Imooth, and cleanly wrought off, as Pear-tree; but if it be a coarfe-grained wood, as Deal, Oak, or the like, you muft prime it with Whiting, as you have been taught in the chapter of black Japan for coarfe-grained woods. When either of thefe are rufhed fmooth, as is required; take a fit varnifhing tool dipt into a gallipot of the thickeft of your Seed-lac-yarnifh, and wet with this varnifh the breadth of a Silver-leaf, which, you muft take up with cotton, and clap on it whilft tis moift, dabbing it clofe to the work, as you have been taught in Guilding. This done, wath again, and lay on another leaf of Silver, ordering it as before, and fo continue, till the whole is fo overfpread with Silver. When tis through drie, with a fine hair-brufh fweep off all the loofe Silver. Next, grind Collins-earth very finely on a grinding-ftone, mixed either with common fize, or gum-water; this I efteem better than Lamblack, becaufe Collins-earth comes much nearer to the colour of the Shell: Being finely ground, mix it with more common fize, or gum-water, as you have made ufe of either in the grinding. With this fpot the darkeft of your Shell, ftriving to the utmoft to imitate it as nearly as tis poffible ; and in order hereunto, I counfel you to procure a picce or more of the true, right Shell, that hath much variety in it; this lying by you, will quicken and affift your fancie, and enable you to perform it with much more eafe and cunning. You may obferve, (when this is done, that feveral reds, lighter and darker, offer themfelves to view on the edges of the black, and fometimes lie in ftreaks on the tranfparent part of the thell: To imitate this, you niuft grind Sanguis Draconis very fine with gum-water; and with a fimall pencil draw thofe warm reds, flufhing it in and about the dark places more thick, but fainter, thinner; and with lefs colour towards the lighter parts of the fhells; fweetning it fo, that by degrees it may loofe its ftrength of red, being intermixt with, and quite loft in the filver, or more tranfparent part. Tis worthy your obfervation, that thofe who are expert and ready at fpotting or workind this imitation, do ufually grind the forementioned colours drie and Chêt:

very 


\section{To counterfeit Tortoise-fhell and Marble.}

very finely upon it ftone, and mix 'èm with fine Lacc-varnifh a's they work them, which is moft agreeable and proper, as I have no. ted before, being not fo apt to polifh off as Size or gum-ivater; notwithftanding; I advife young beginners to ufe fize or gumb water, for I fnppofe they are not able to do it fo well, that it fhould not require a review and correction; for then they may with eafe and a little care rub out any faulty place, and go over it again, until tis done artificially, (but this convenience is not to be had, if you imploy Lacc-varnifh at the firft.) When this is done, and dried, give it fix wafhes of your Seed-lacc-varnifh; let it reft one day; after which time rufh it gently; till tis finooth and fit for the fecond operation : in order to which, grind Dragons-blood and Gambogium, in an equal, but fimall quantity, yery finely; put them into as much Seed-lacc-varnifl as will wafh it fix times more: permit it to ftand twelve hours,and then allow it the third varnifhing, and with the laft mixture wafh it fo often, till your filver is changed into gold, or a colour like it. Note, that your firft wafhings may be with the coarfe, the two laft with the fine and cleareft of your Seed-lacc-varnifh; avoid making your varnifh too thick and high coloured with Gambogium, and Sanguis Draconis, but heighten it by degrees, otherwife your filver will be too high-coloured, before you have given it a fufficient body of varnifh. When it has ftood two days, polifh and clear it up, as you have been inftructed in the treatife of black varuifhing.

Anotlier way to counterfeit Torioife-fjelli:

Firit, prime, lacker, and fize your work in oyl very thin, as you are taught before in the Art of Guilding, and when your filver is laid on and dried, let thefe colours be ground fine and thick in drying-oyl, placing them on your Pallet; they are, burnt Umber, lins-earth, brown Pink, and Lake. Do over your work with Turpentine-varnifh, and whilft it is wet, mix brown Pink and Lake thin with varnifh; and lay all your fainteft clouds or fpots, which you may foften very fweetly, feeing your varnifh is moift. After three hours ftanding, or longer, if the colours are drie, with a large, foft Tool, pafs it lightly over; and again wetting it, lay in your clouds more warm and dark with Umber and Collins-earth, before tis drie; always obferving the life, and fweetning your work, which is blending and mixing two colours after they are laid, fo that you cannot perceive where either of them begin or end, but infenfibly join with each other. If the clouds are not dark enough, repeat the varnifhing and clouding once more, where tis required. When tis well dried, glaze it two or three times with brown Pink, yet a little tincture of Verdegreas in it will not be amif; if you had rather, you may varninh it with Lacc-varnith, and finifh it as you did the former. 
Whiten and prepare your wood in all refpects as you do for white Japan; and after you have done it over with flake white, or white-lead, if you defign a white with fome veins, ufe fome Vineblack, (which is made of the cuttings of Vines burnt and grinded, inix two or three degrees of it with white-lead and a very weak fize being warmed, until you have produced the intended colour for the clouds and yeins of the Marble. Being thus far advanc't; call for a large, clean brufh, wet your piece over with water, and before tis dry, with a great Cantels-hair-pencil, dipt in the paleft thin mixture, flufh or lay the fainteft large clouds and veins of your Marble, which being laid on whilft the work is wet, will lie fo foft and fweet, that the original will not exceed it. Then if your work be not too drie, take a fimaller pencil; and with a colour one degree darker than the firft, touch all the leffer veins and variety of the Marble: If your work drie too faft, wet it again with the bruth and water, and lay not on your colours when the water is running off, left they bear it company. Laftly, take a fmall-pointed feather, and with the deepeft colour touch and break all your fuddain or fimaller veins, irregular, wild, and confufed, as you have them in the natural Marble. After a days drying, cold-clear it, that is, do it over with Ifinglafs or Parchment-fize; and then varnifh, polifh, and clear it up, exactly in all things according to the directions for white Japan, to which places, and others above mentioned, we refer you. By mixing other colours this way, any fort of Marble is fubject to your imitation; and, if neatly done, well polifht, and varnifht, will not only exceed any Marbling in oyl, but will in beauty and glofs equal the real ftone.

\section{CH A P. XXVII. \\ of Dying or Staining Wood, Ivory, Ec.}

To Dye Wood a beautiful Red.

VV

oods, that are very white, take this dye the beft of any : fet

a kettle of water boiling with a handful of Allom, caft your wood into it, permitting it to boil a little; that done, take your wood out, and put into the faid water two handfuls of Brafil. wood, then return your wood into the veffel again to boil for a quarter of an hour, and tis concluded. When dry, you may rufh and polifh it, or varnifh it with the tops of Seed-lacc-varnifh, and polifh it; by which management, you will find the wood covered with a rich and beautiful colour.

$$
\text { To ftain a fine Yellow. }
$$

Take Burr or knotty Afh, or any other wood that is white, curled, and knotty; fimooth and rufh it very well, and having warmed 
it, with a brufh dipt in Aqua fortis wafh over the wood, and hold it to the fire, as you do Japan-work, until it leaves fimoaking: when dry rufh it again, for the Aqua fortis will make it very rough. If to thefe you add a polifh, and varnifh it with Seed-lacc, and then again polifh it, you'l find no outlandifh wood fuxpafs it; for the curled and knotty parts admit of fo much variety, being in fome places hard, in others foft and open-grained, to which Aqua fortis gives a deeper colour, than to the harder and more refifting parts. In fhort, you'l perceive a pleafing variety interwoven, beyond what you could imagine or expect. If you put filings or bits of metals, as brafs, copper, and iron, into the Aqua fortis, each metal will produce a different tincture: the beft French Piftols are ftockt ge nerally with this fort of wood, and ftained after this manner.

\section{To Dye or Stain Woods of any colour, for Inlaid or Flomer'd work, done} by the Cabinet-makers.

Ufe the moifteft horfe-dung you can get, that has been made the night before; through a fieve or cloath fqueez out what moifture you judge fufficient for the purnofe. convey it into feveral fmall veflels fit for the defign; in each of thefe diffolve of Roach-allom, and Gum Arabick, the bignefs of a nutmeg, and with them mix reds, blews, greens, or what colours beft pleafe you, fuffering them to ftand two or three days, yet not without often ftirring them. Then take your woods (of which I think Pear-tree is the beft if $t$ be white,) cut them as thick as an half-crown, which is in all reafon thick enough for any Fineered or Inlaid work, and of what bredth you pleafe; making your liquors or colours boiling hot, put the wood into it, for as long time as will fufficiently colour them; yet fome muft be taken out fooner than the reft, by which means you'l have different thades of the fame colour; for the longer they lie in, the higher and deeper will be the colours: and fuch variety you may well imagin contributes much to the beauty and neatnefs of the work, and agrees with the nature of your parti-coloured flowers;

To Dye or Stain Wood Black.

Take Log-wood, and boil it in water or vinegar, and whilft very hot brufh or ftain over your wood with it two or three times; then take the Galls, and Copperas, well beaten, and boil them well in water, with which wath or ftain your work fo often till it be a black to your mind; the oftner it is layed, the better will your black be : if your work be fmall enough, you may fteep it in your liquors inftead of wafhing it.

\section{The best Black Dye for Ivory, Horn, Bone, \&c.}

Put pieces of Brafs into Aqua fortis, letting it ftand till tis turned green, with which walh your Ivory (being polifhed) once or twice. Next, boil Logwood in water, into which put your Ivorys whilft tis warm, and in a little time it gives a finc black, whicli

$$
\text { Y } 2
$$


you muft now rufh and polifh again, and twill have as good at glofs and black as any Japan or Ebony.

If you defire any foldage, flowers, or the like fancies thould remain white, and of the fame colour with the Ivory; draw them neatly on the Ivory with Turpentine-varnifh, before you ftain it ; for thofe places which you tonch with the varnifh, are fo fecured by it, that the Dye cannot approach or difcolour them. After tis dyed, if you can hatch and thadow thofe fancies with a Graver, and fill the lines by rubbing and clearing üp the: whole with Lamblack and Oyl; it may add much to its ornament and perfection.

$$
\text { To Stain a Green colour on Wood, Ivory, Horn, or Bones. }
$$

Firft, prepare either of them in Allom-water, by boiling them well in it, as you were juft now inftructed. Afterwards grind of Spanifh-green, or thick common Verdegreas, a reafonable quantity, with half as much Sal-Armoniack; then put them into the ftrongeft wine-vinegar, together with the wood; keeping it hot over the fire till tis green enough : if the wood is too large, then wath it over fcalding hot, as in the other inftances.

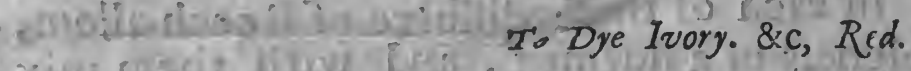

Put quick-lime into rain-water for a night; ftrain the clear through a cloath, and to every pint of water add half an ounce of the fcrapings of Brafil-wood: 'having firtt-boil' d it in Allon-water; then boil it in this, till tis red enough to pleafe you.

Thus, Courteous Reader, are we at lenghth arriv d at our de. fired Port: : Our Perforinances have been no way inferiour to our Promifes. What we ingaged for in the beginning, we have punctually accomplifht; and nothing certainly remains, but that you - convert our Precepts to Practice; for that will be the ready way to examin, and try, whether they are falfe or infufficient. We have all along been directed by an unerring Guide, Experience; and do therefore advife you, upon the leaft mifcarriage, to make a diligent review, and doubt not but fecond thoughts will convince you of too flightan obfervance. W We defire you'd be as exact and regular in your performances,as we have been in ours; for by thefe means, Satisfaction will attend both Parties, all our defigns muft fucceed to our wifh, and our Labours fhall be crowned with fuccefs and re.

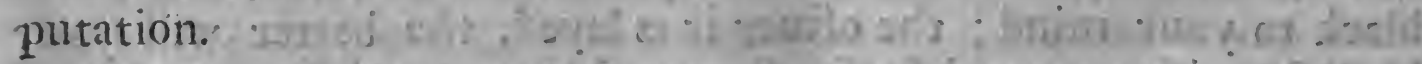

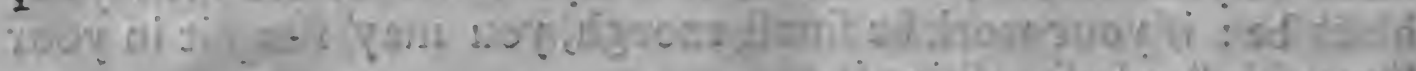

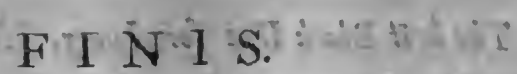

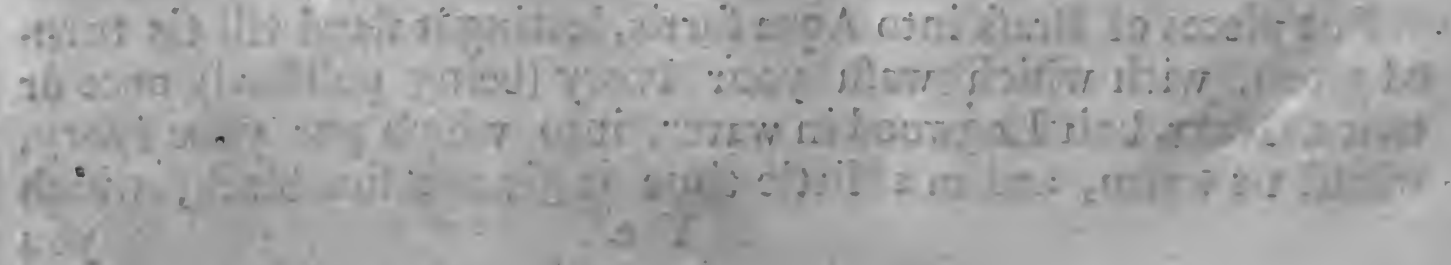




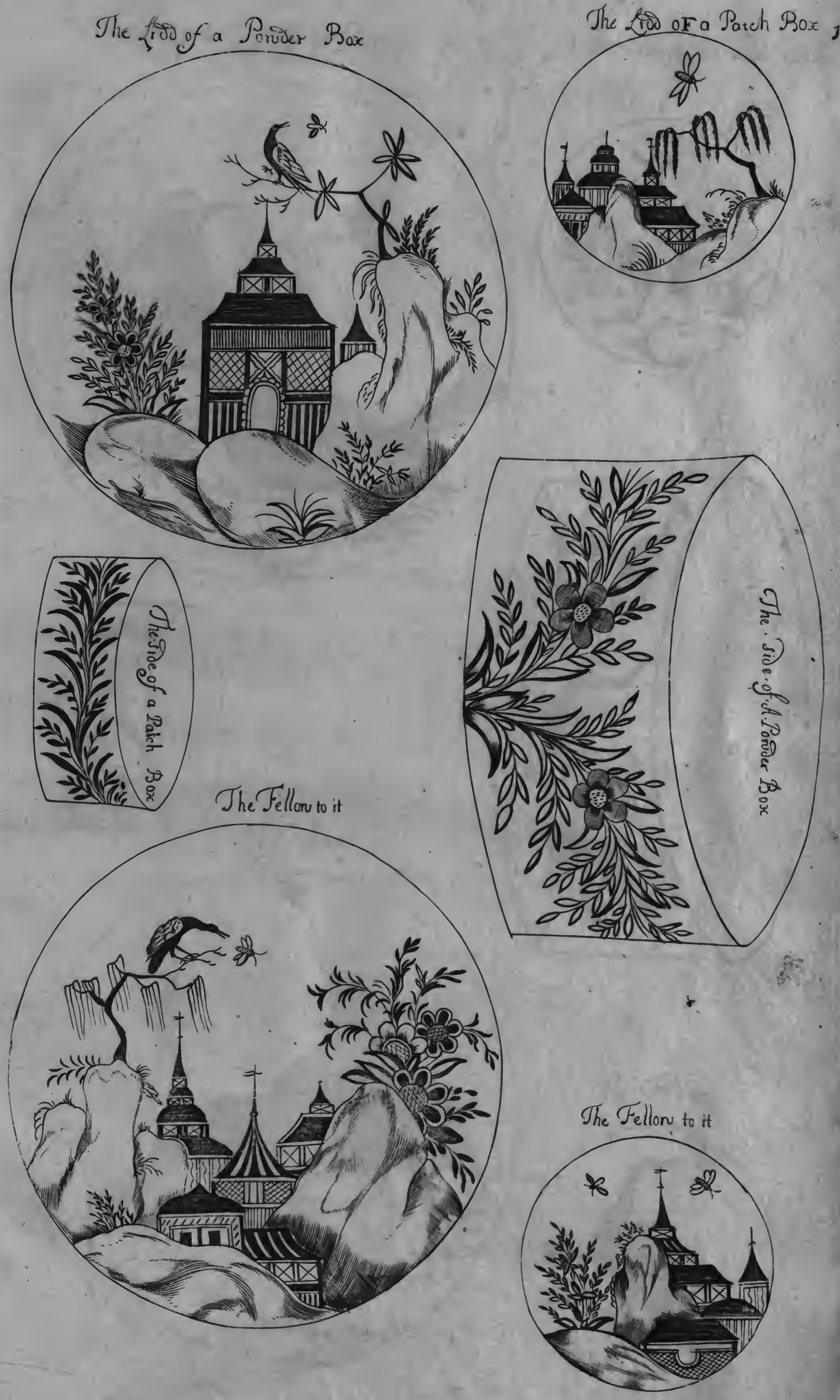




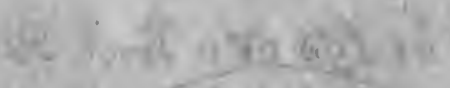

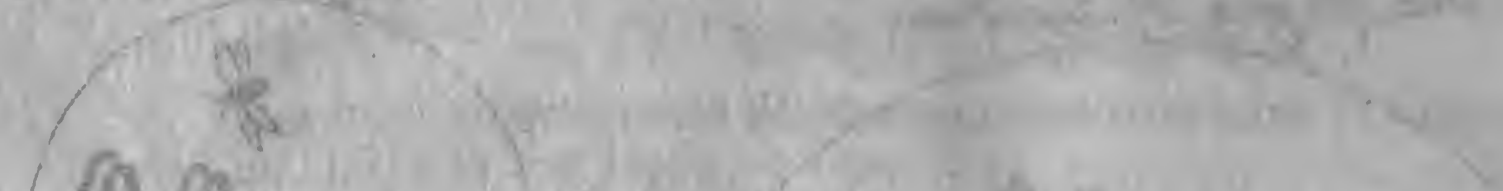

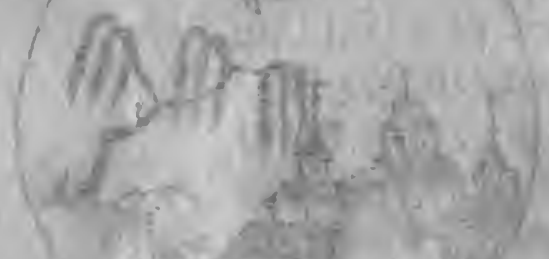
\&

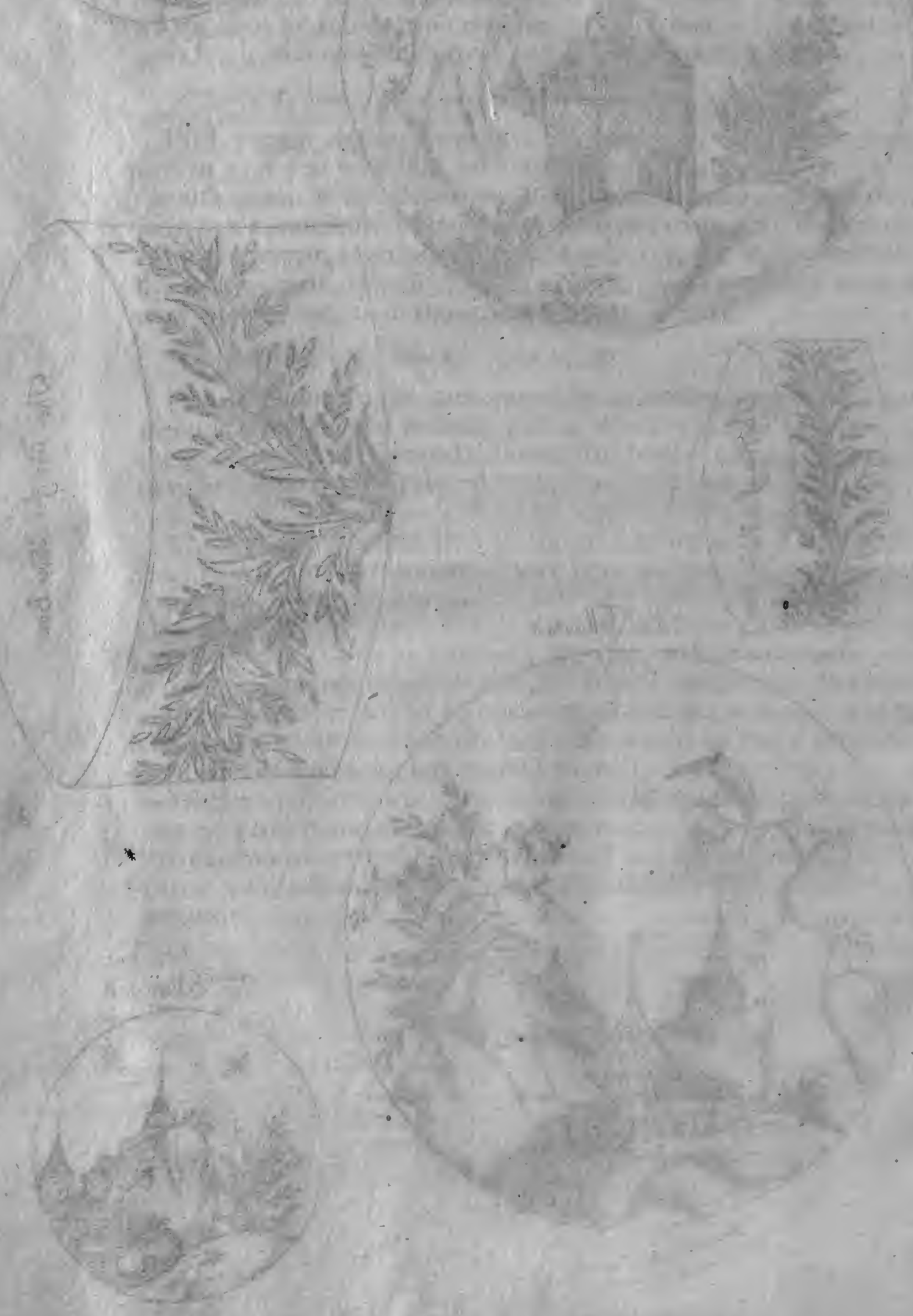

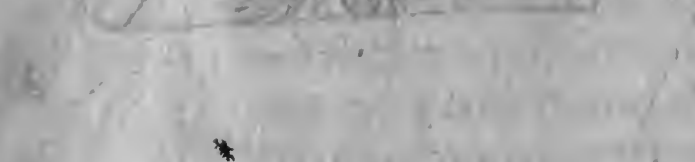
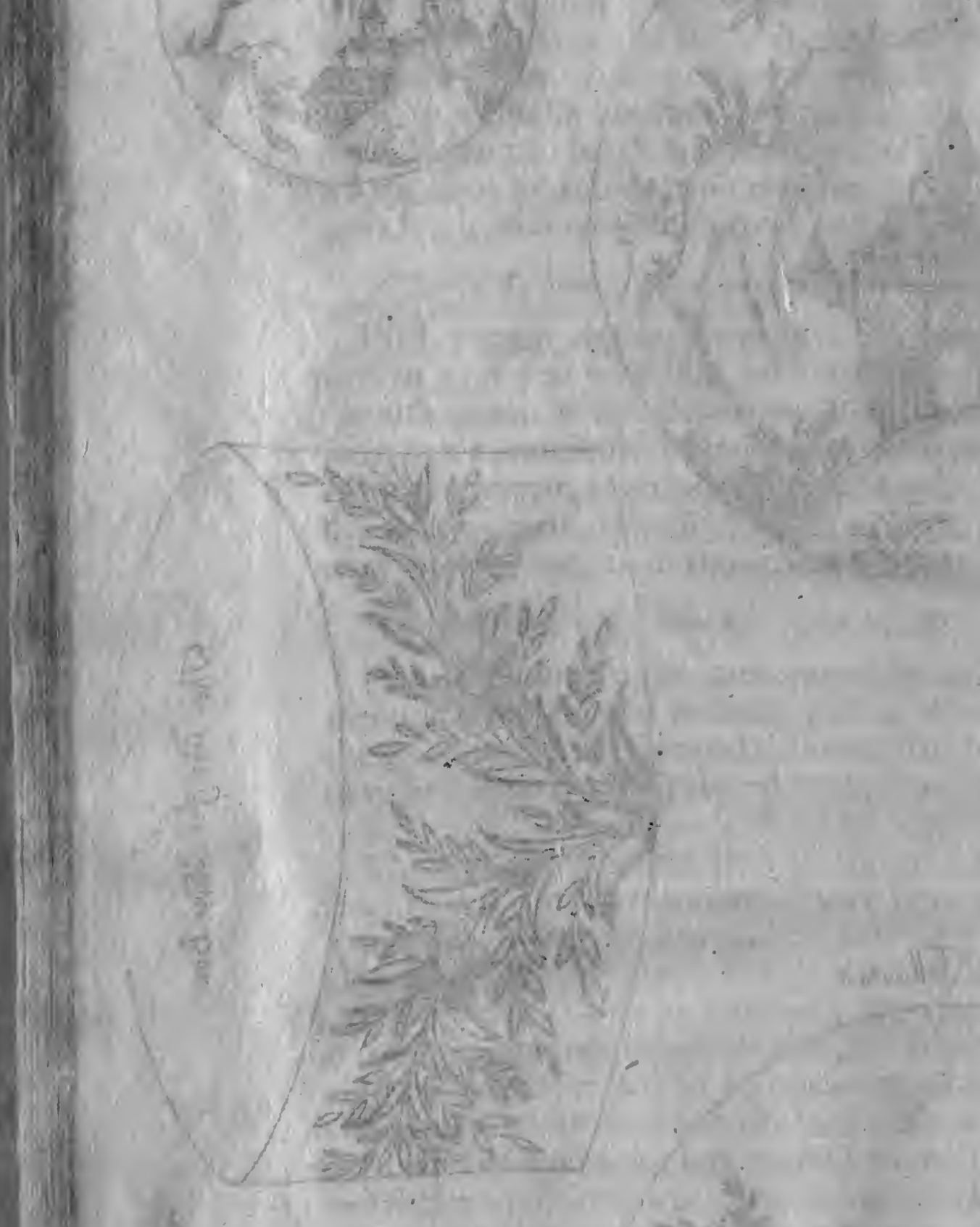
Wther yattorn for ower 'Boxes

Other Jattens for Patch Sosoxes
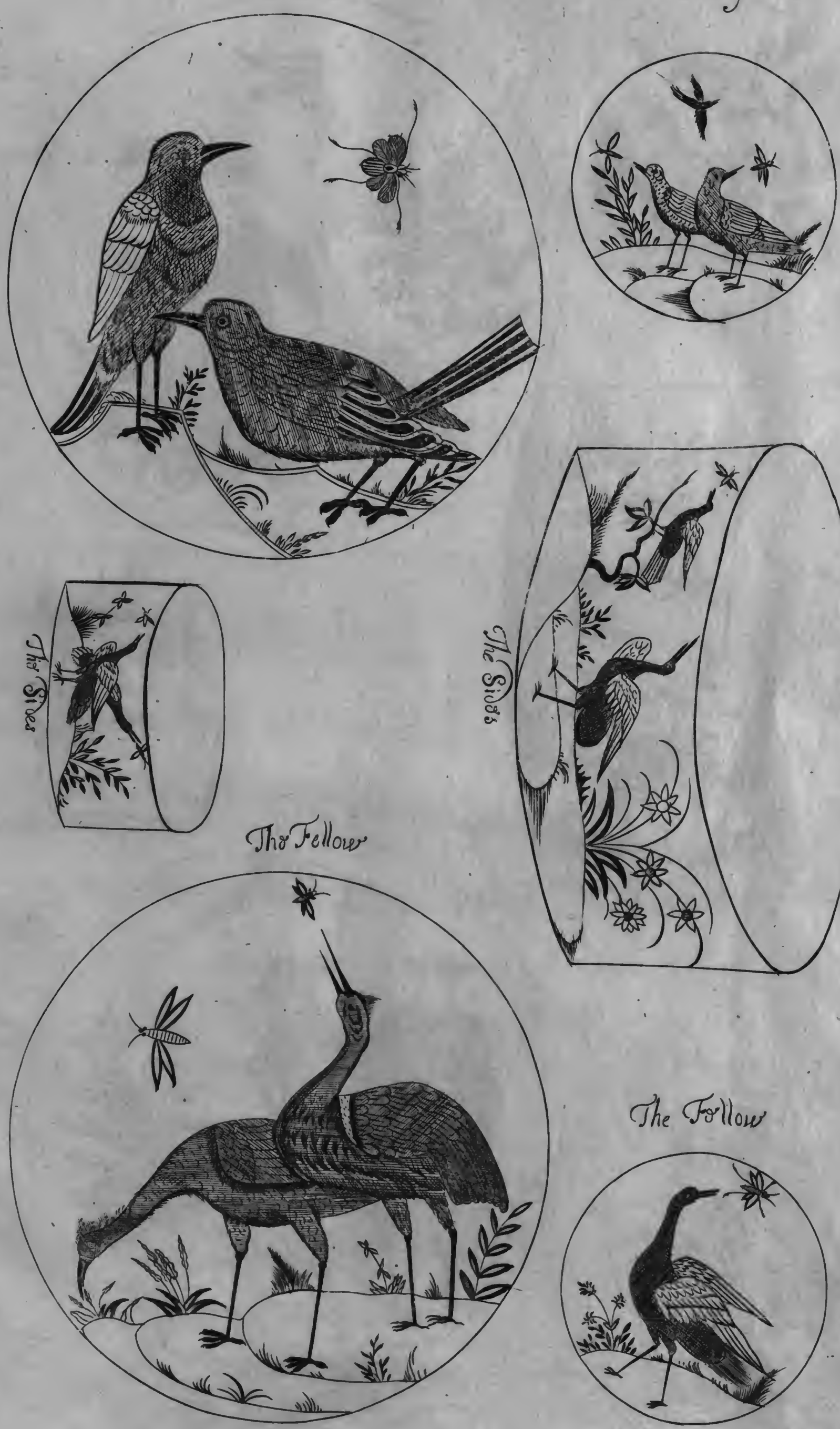

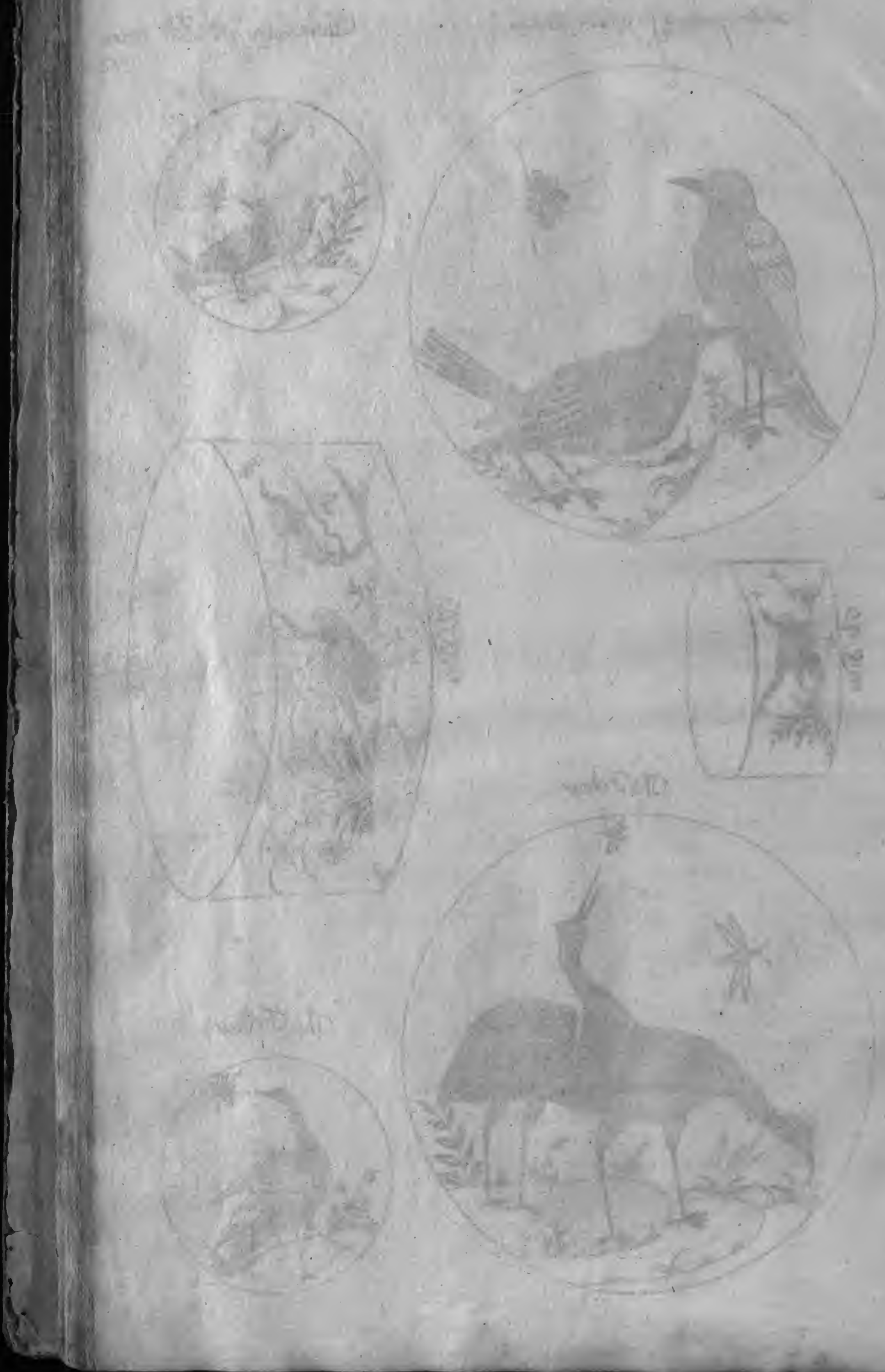


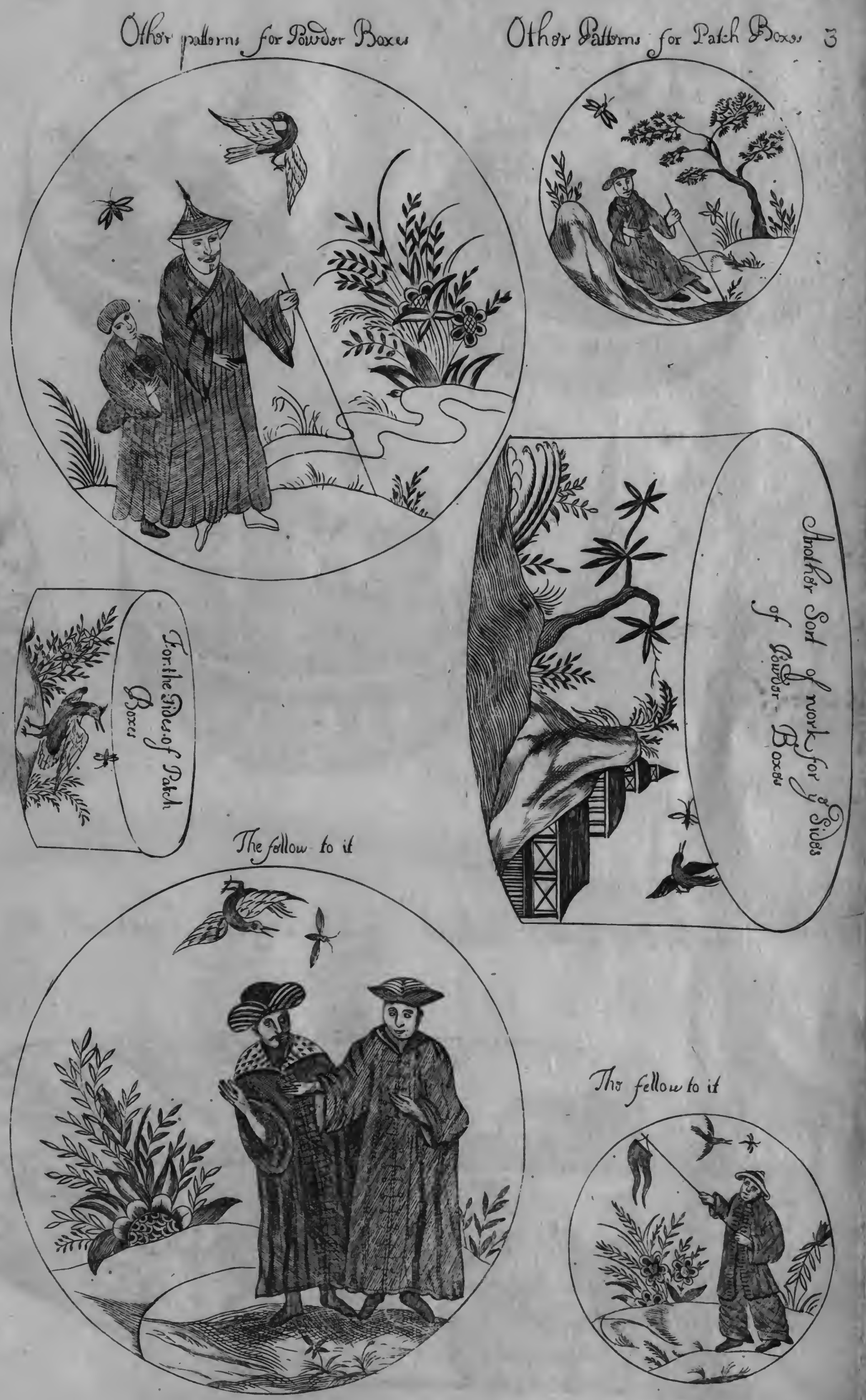




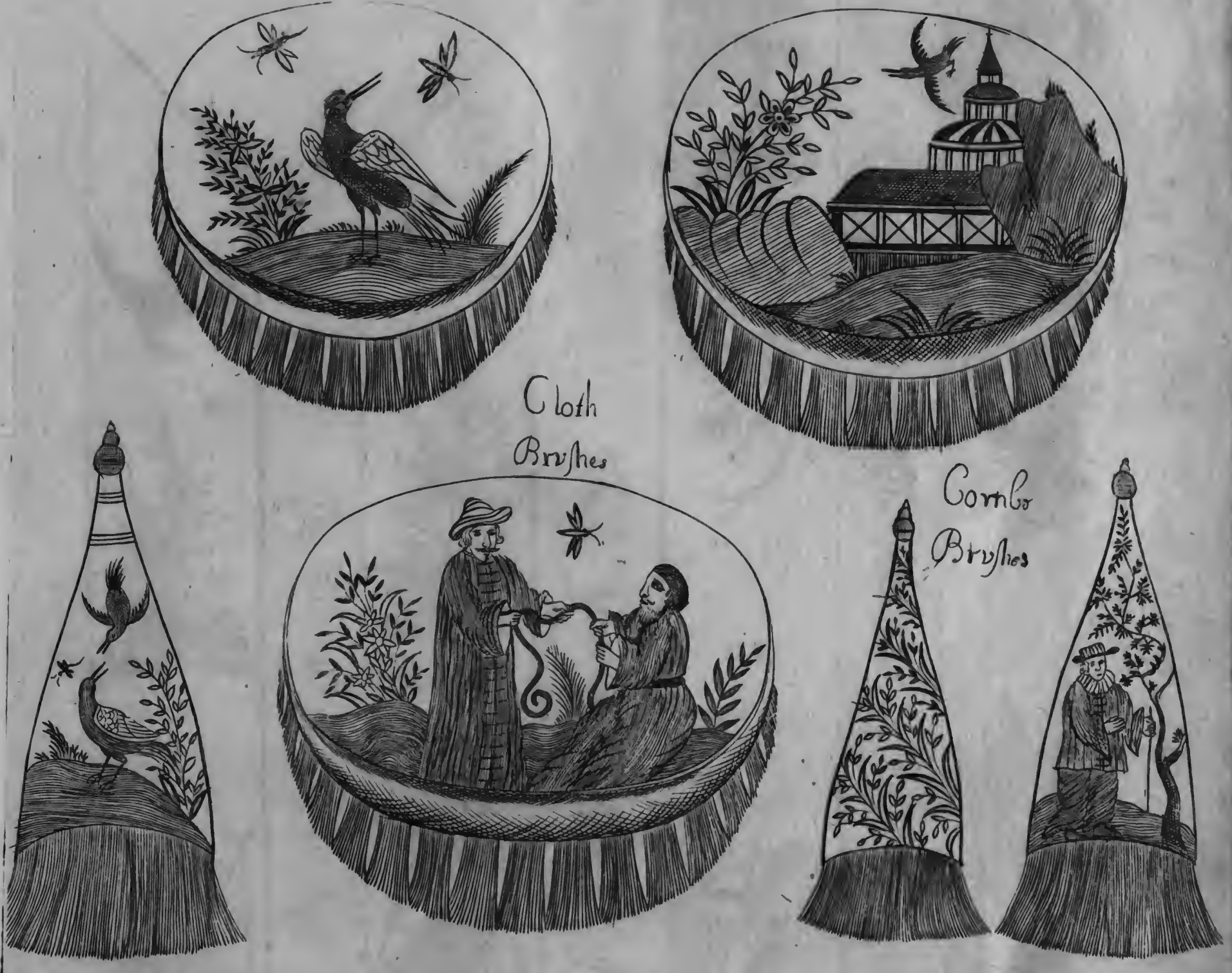

A Pincushing Trunks for Pendents Tecklace Rings or Jewells

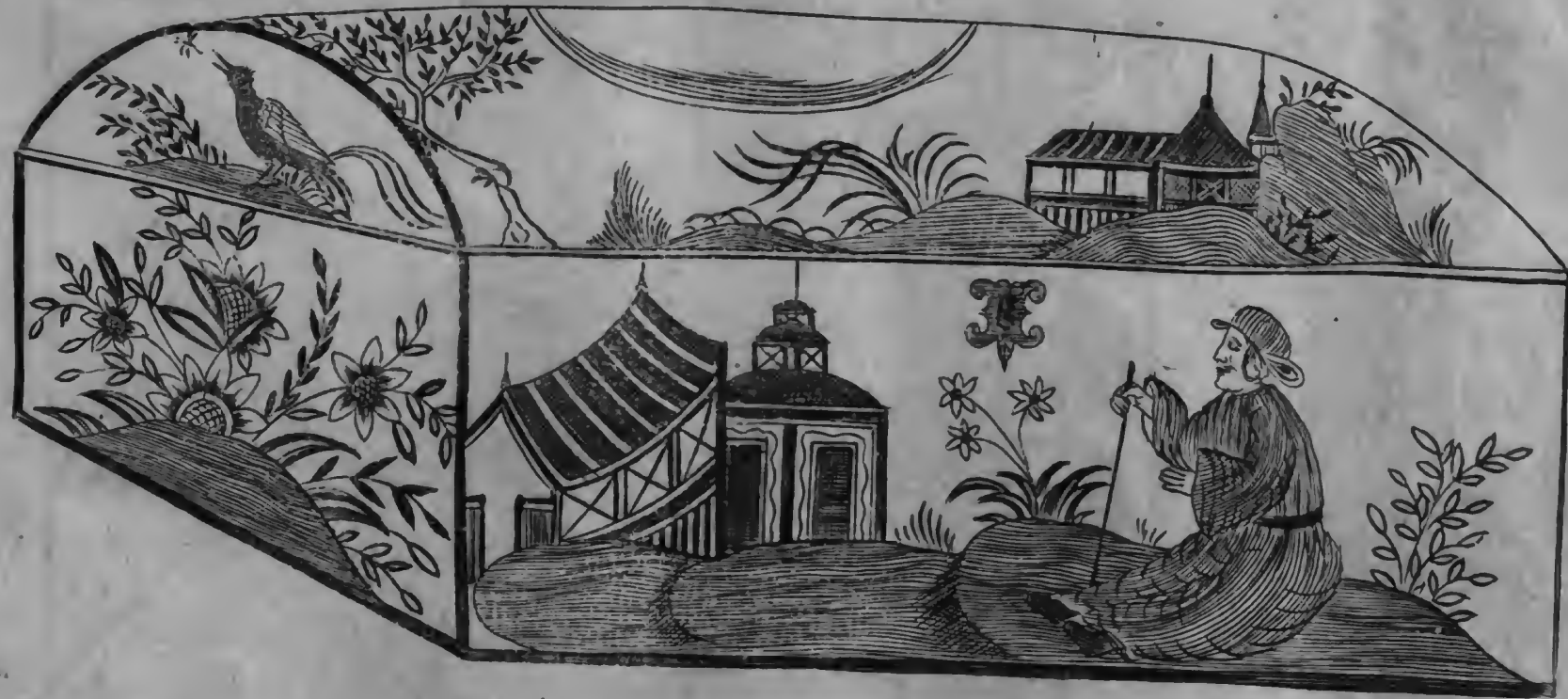





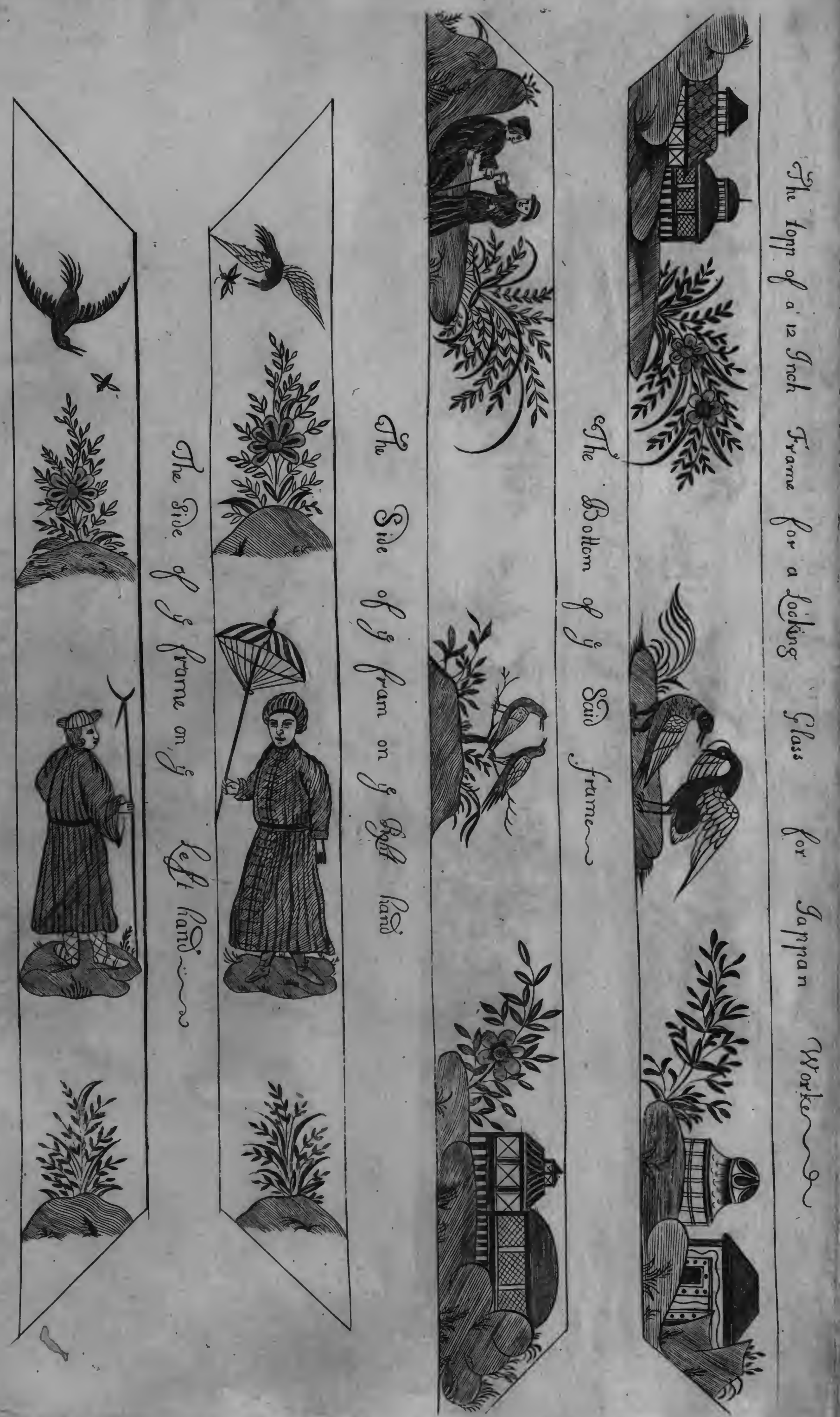




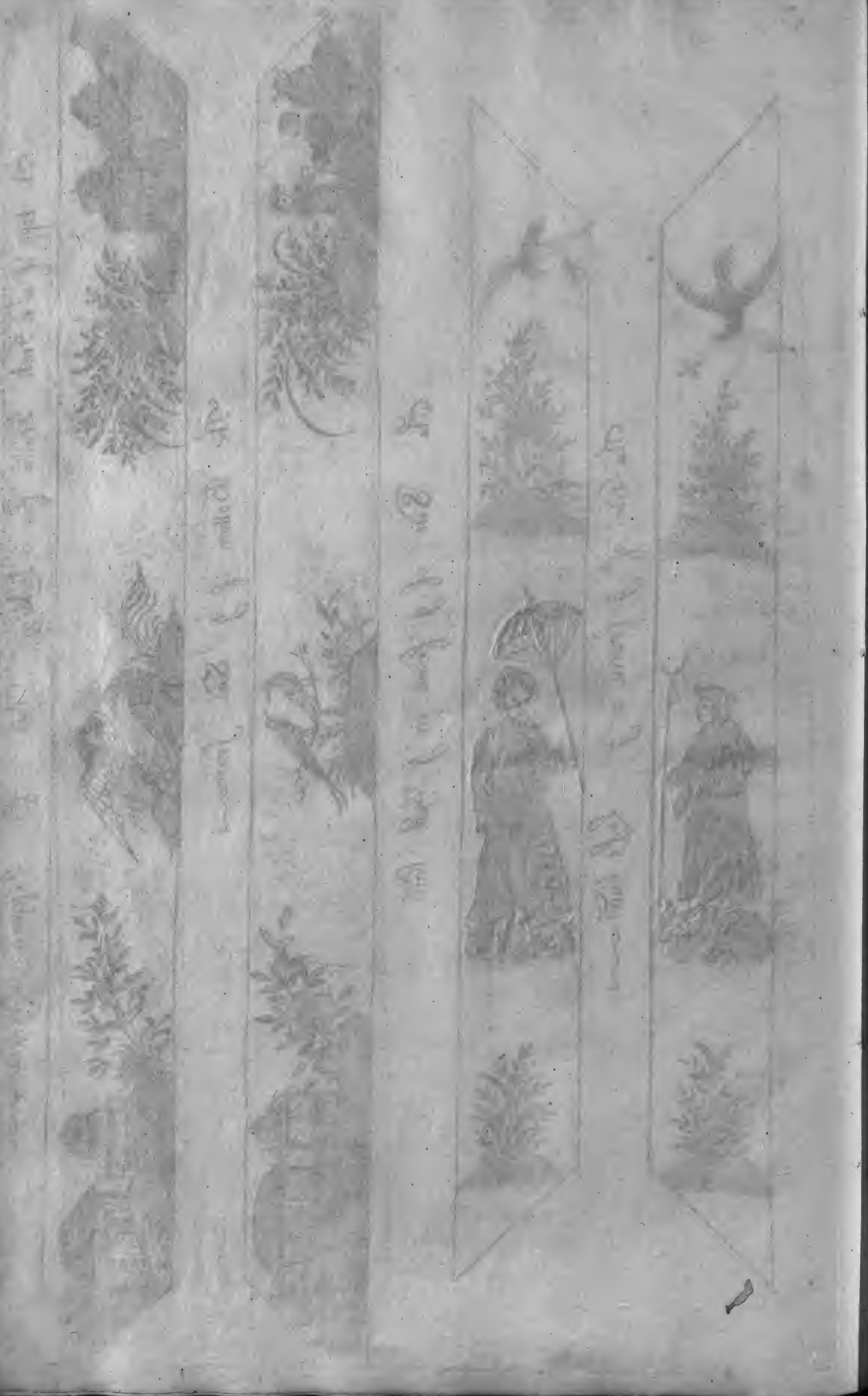



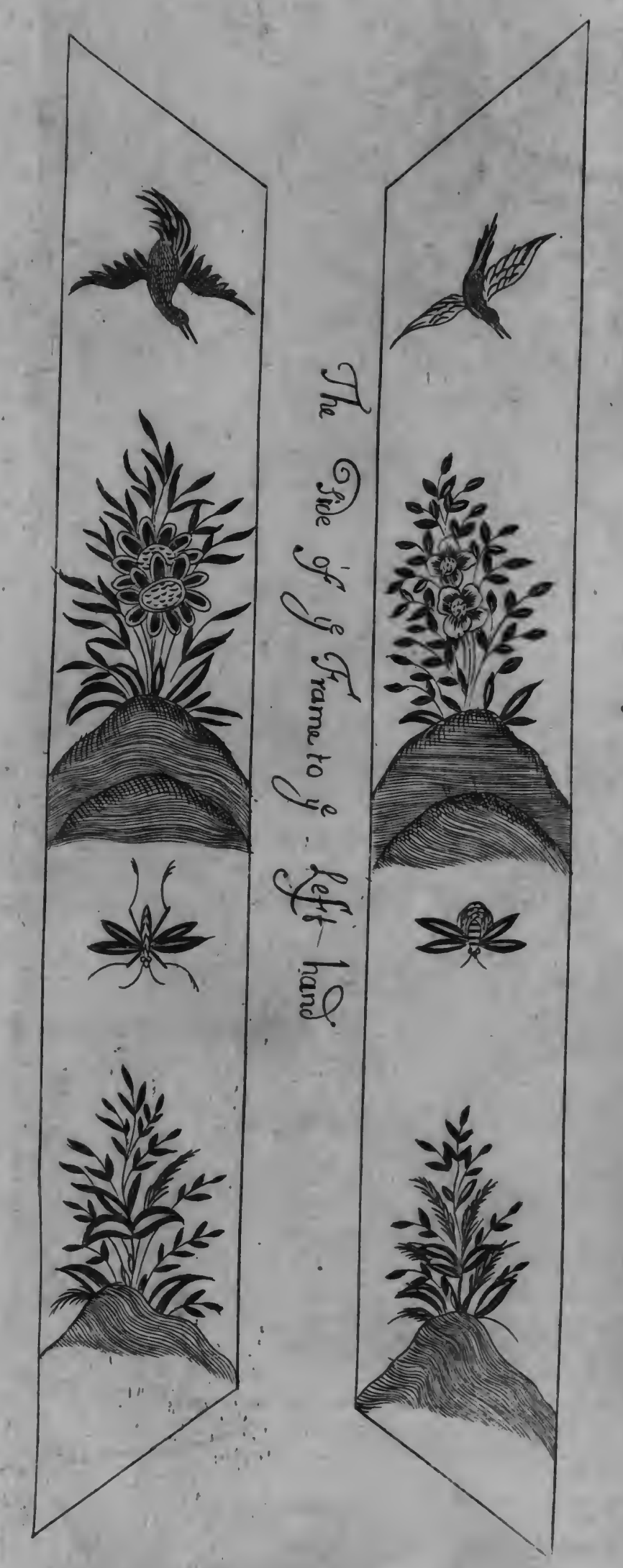

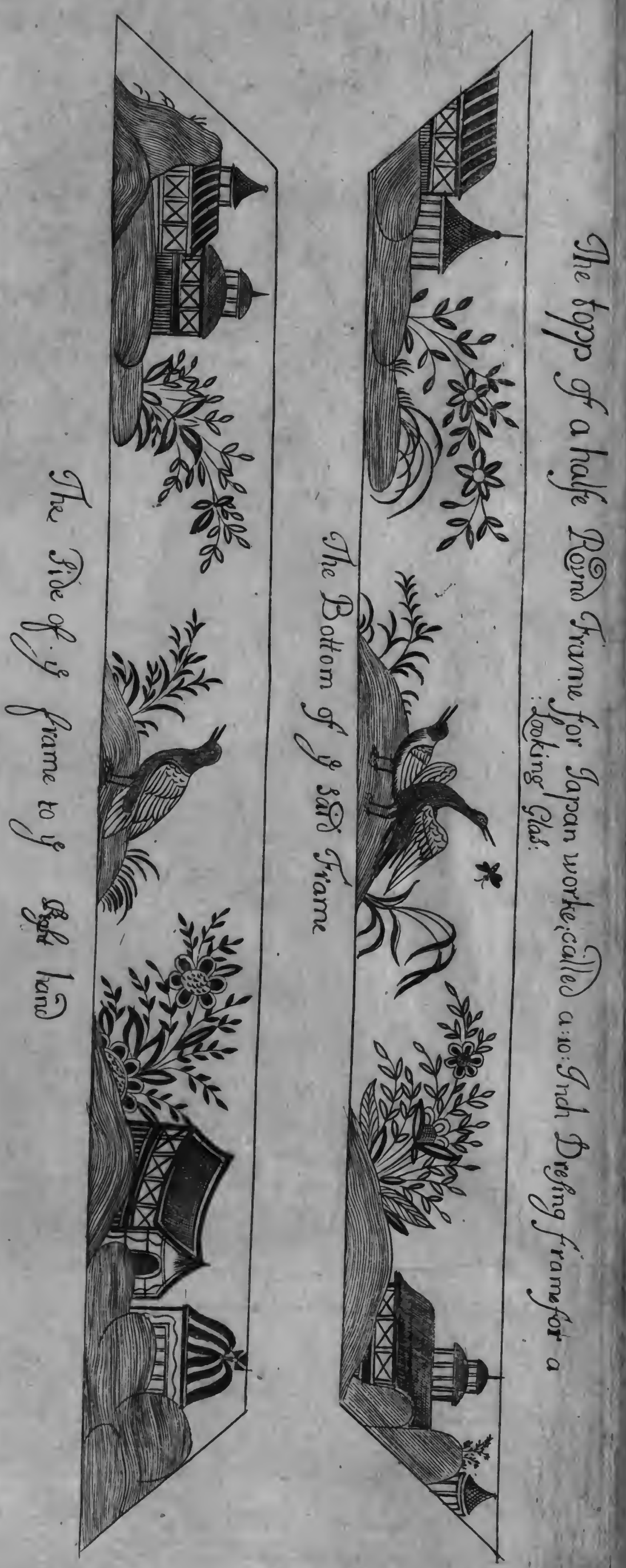



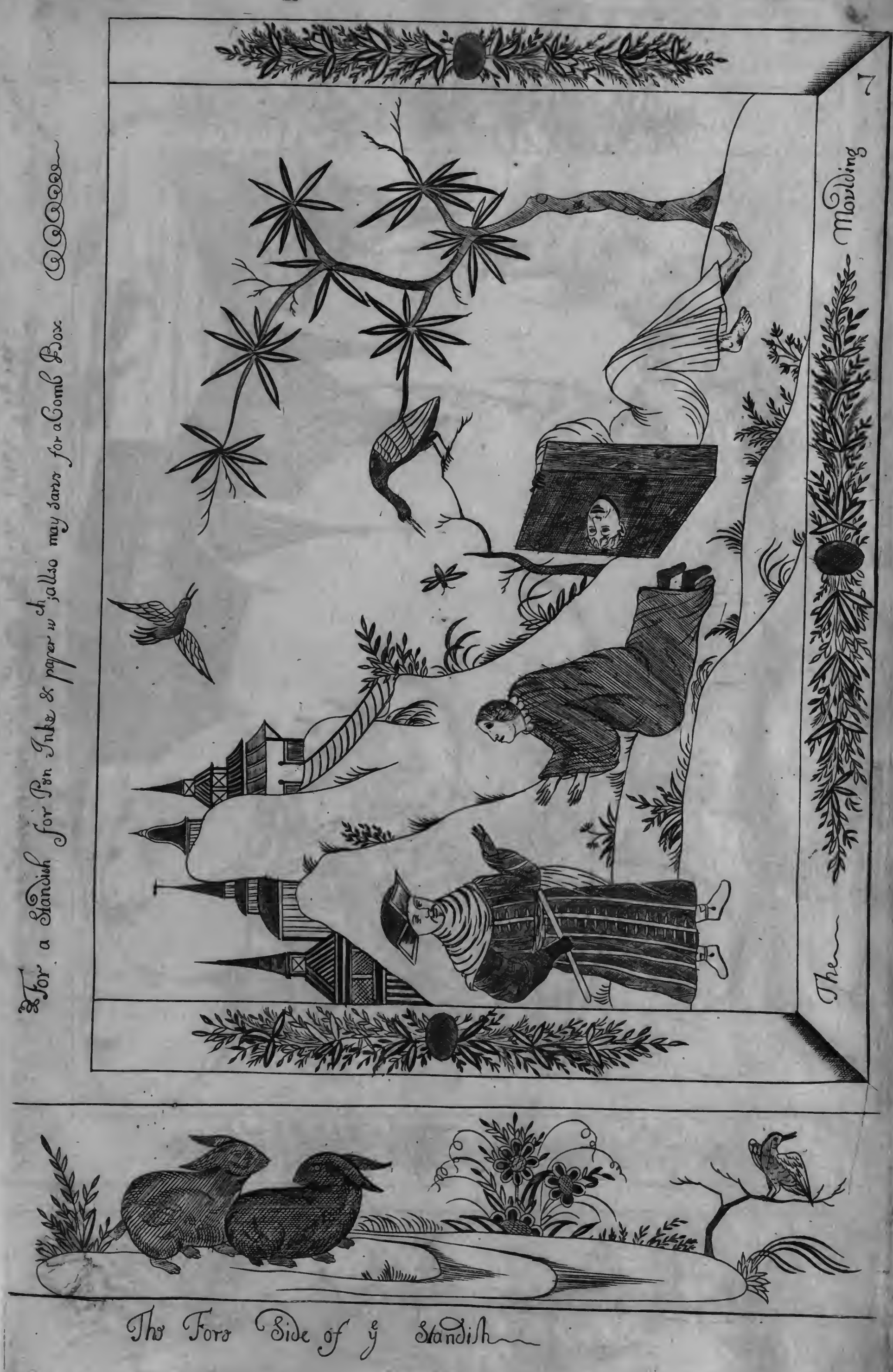


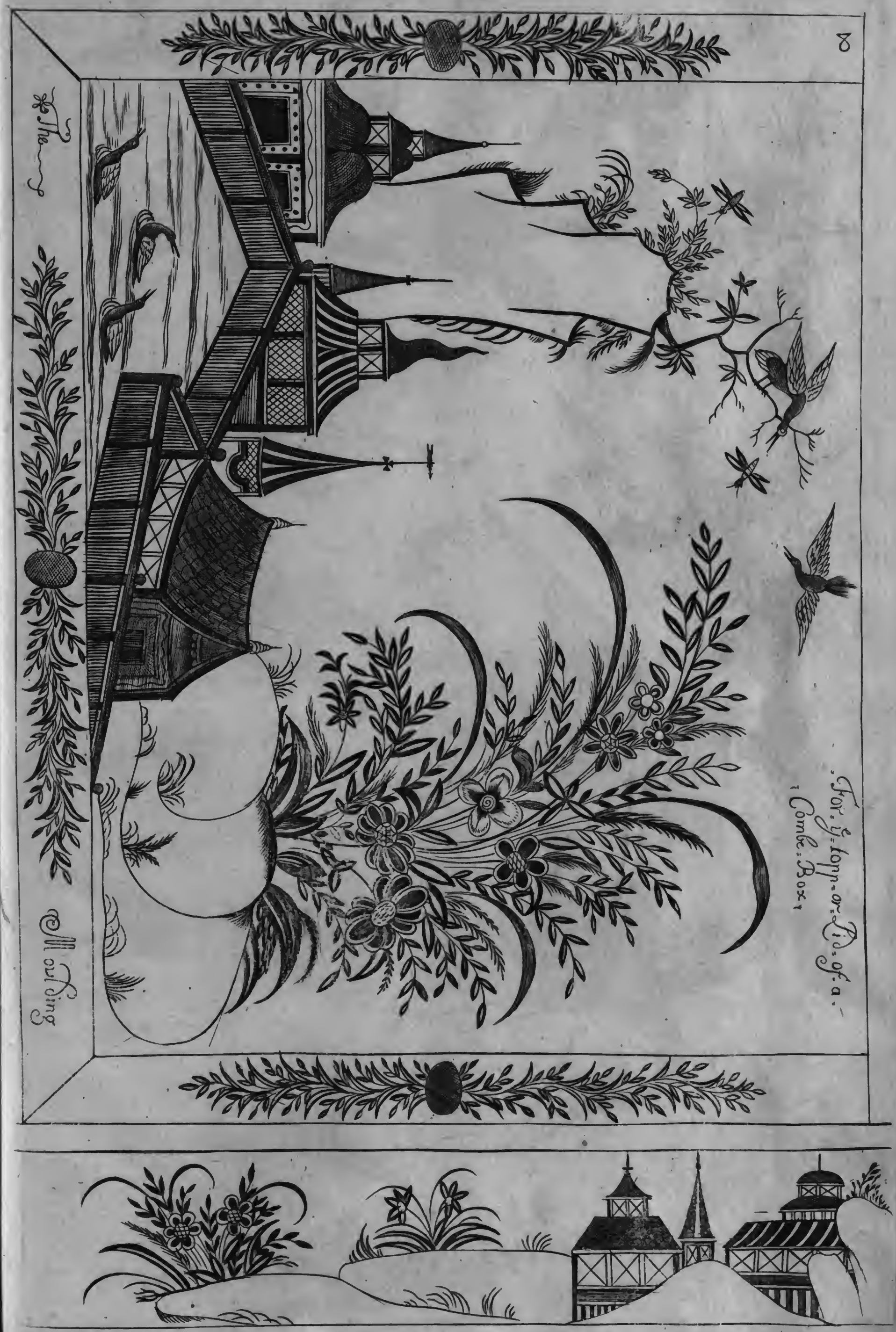

Whe for Bive of $y$ Combe Boxw 



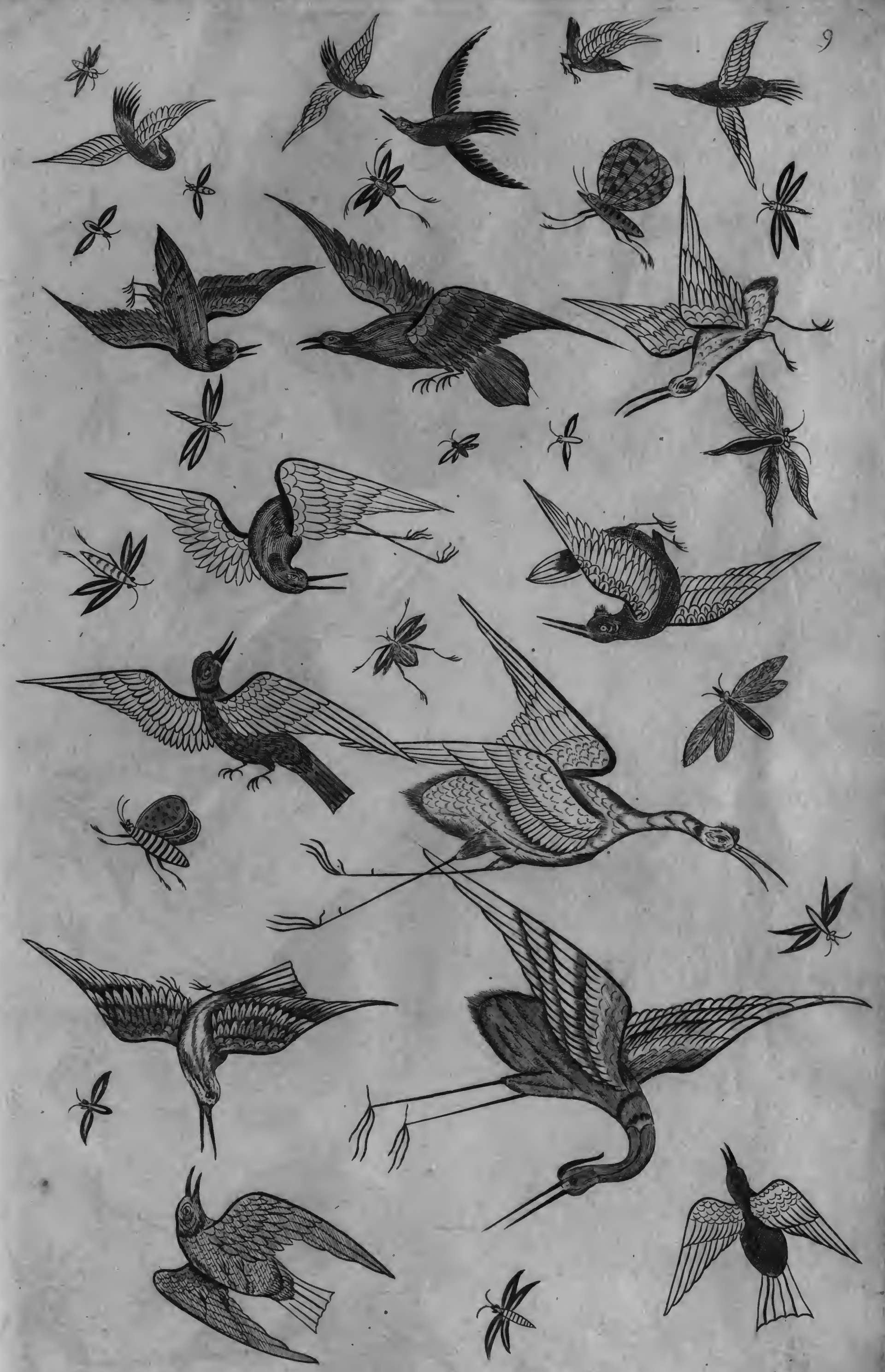




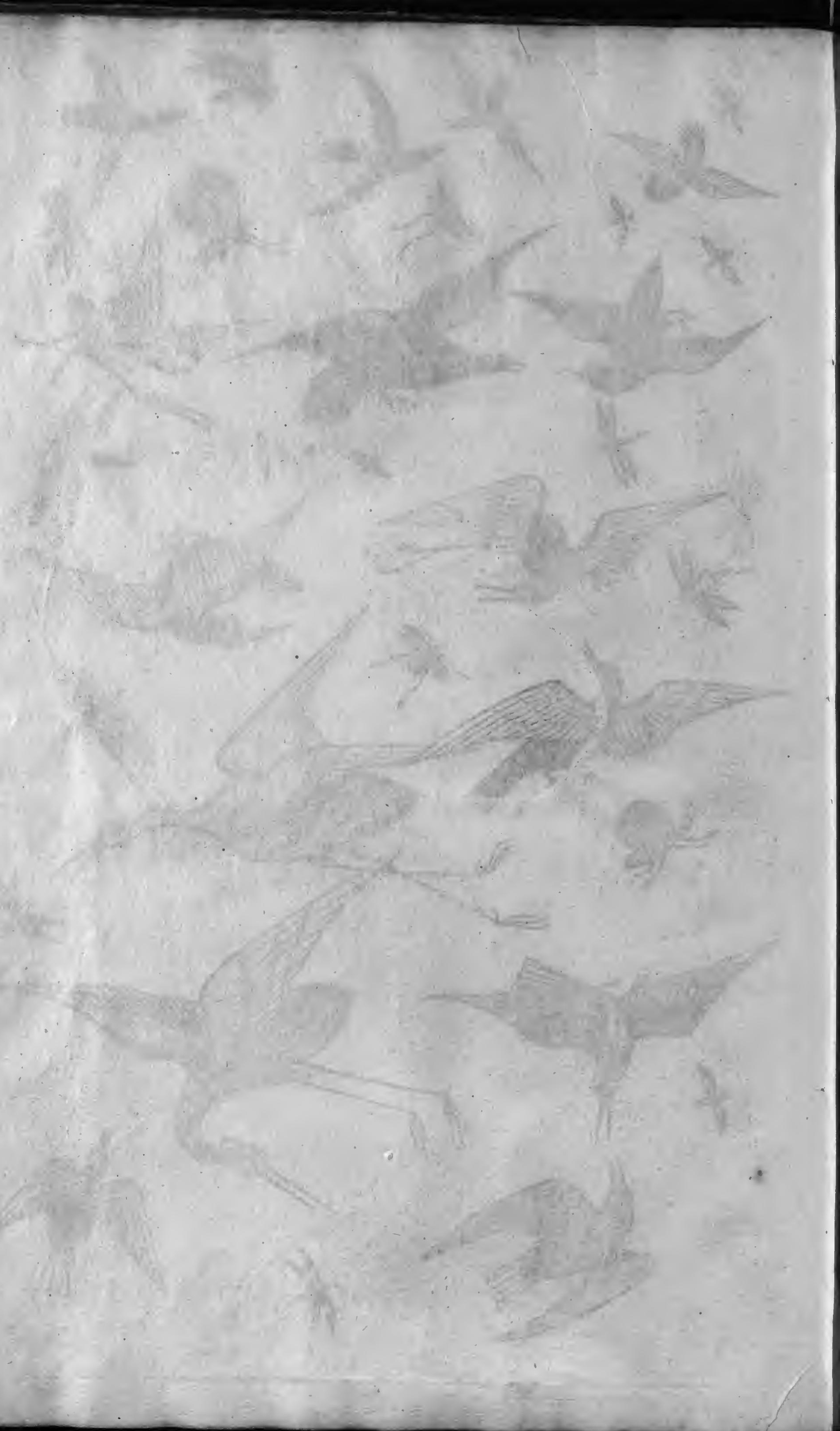




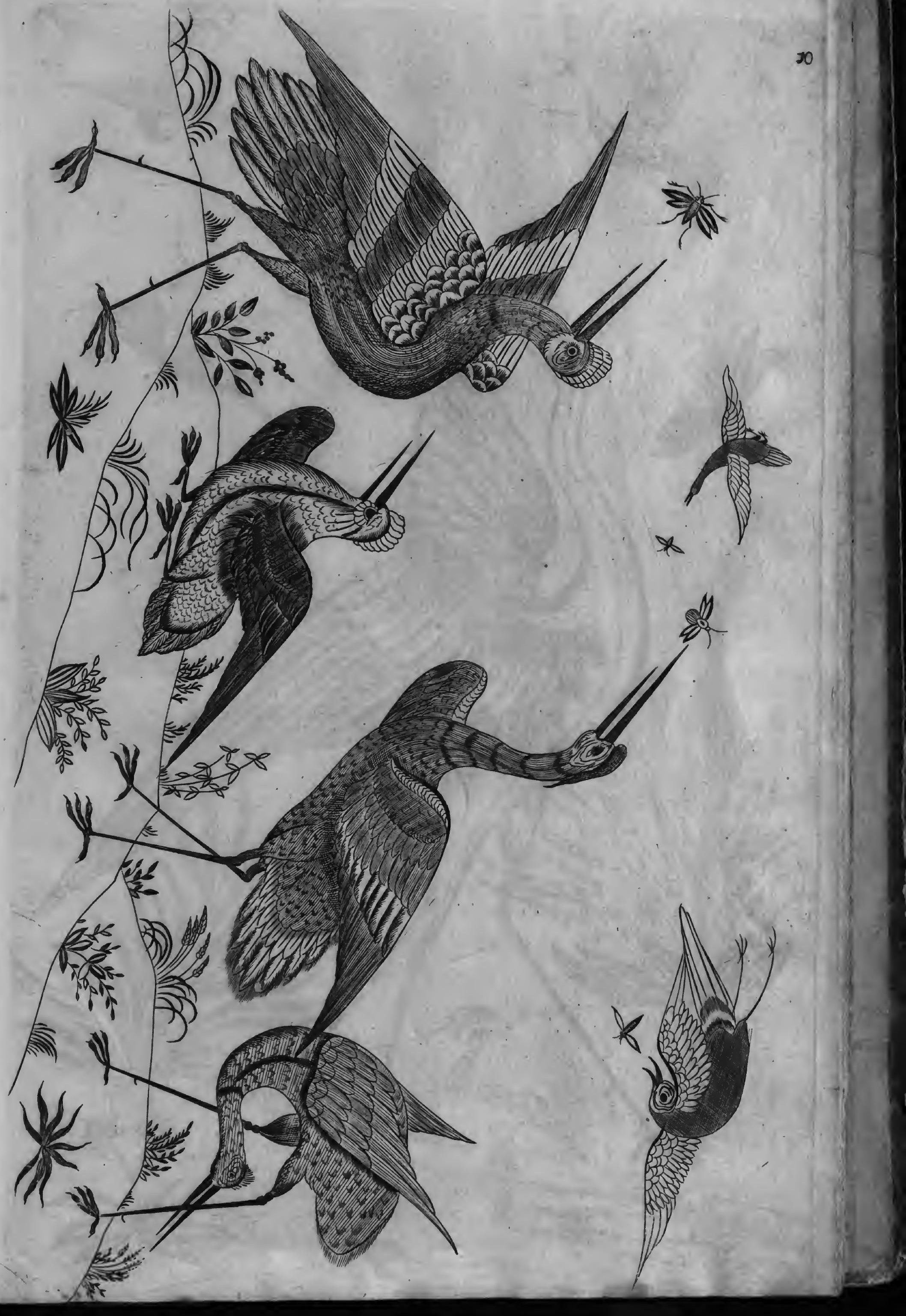




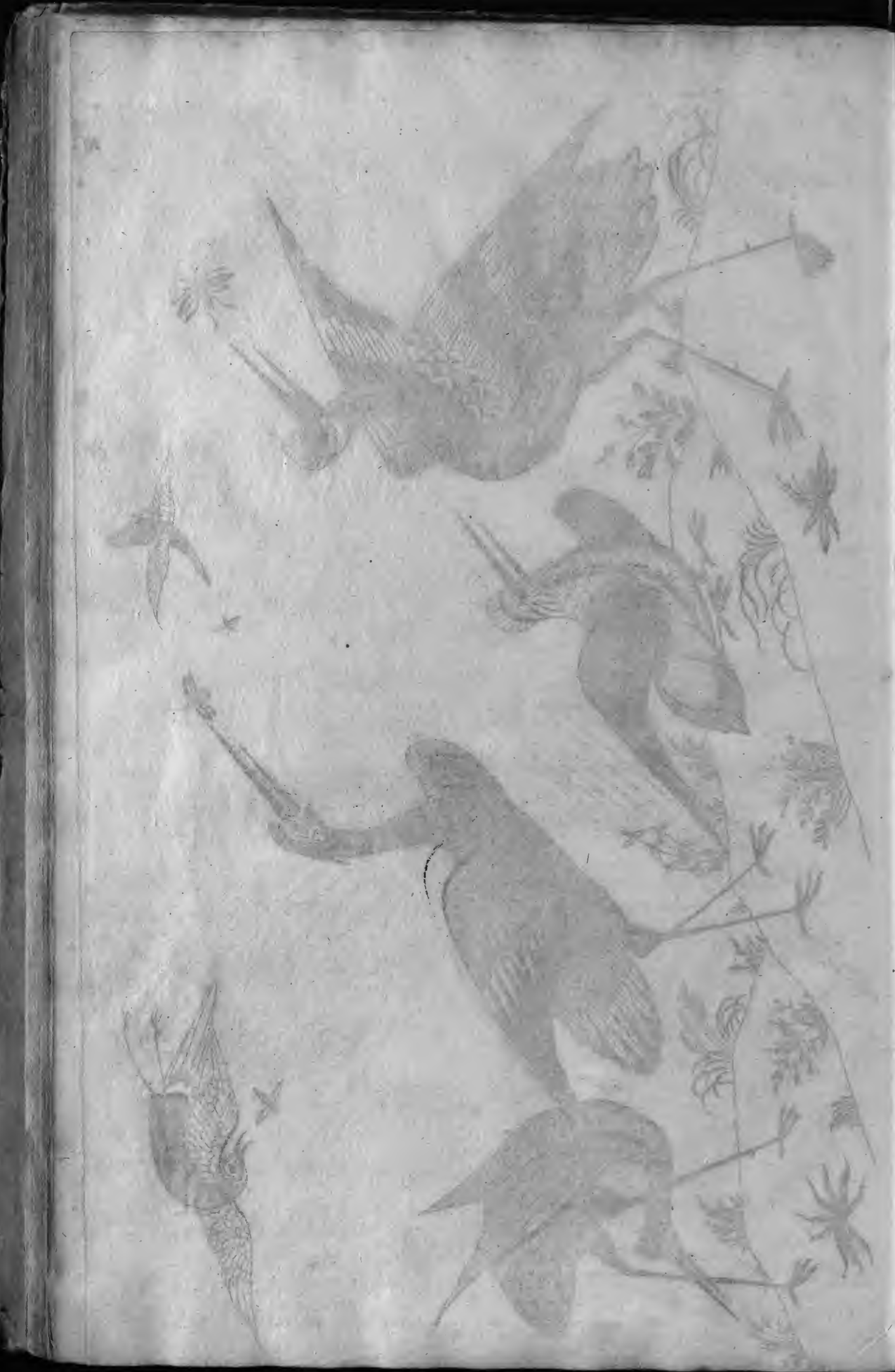




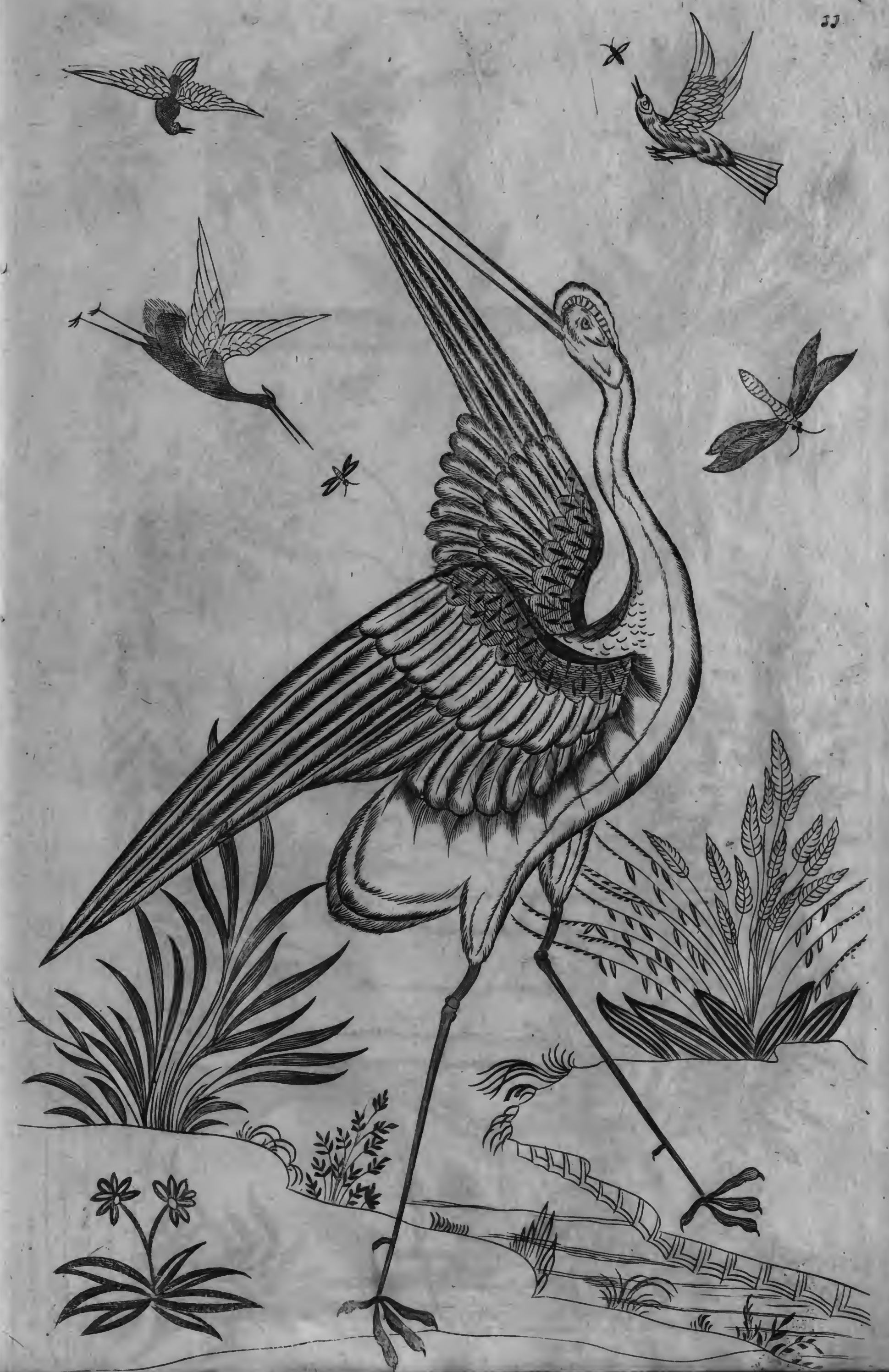




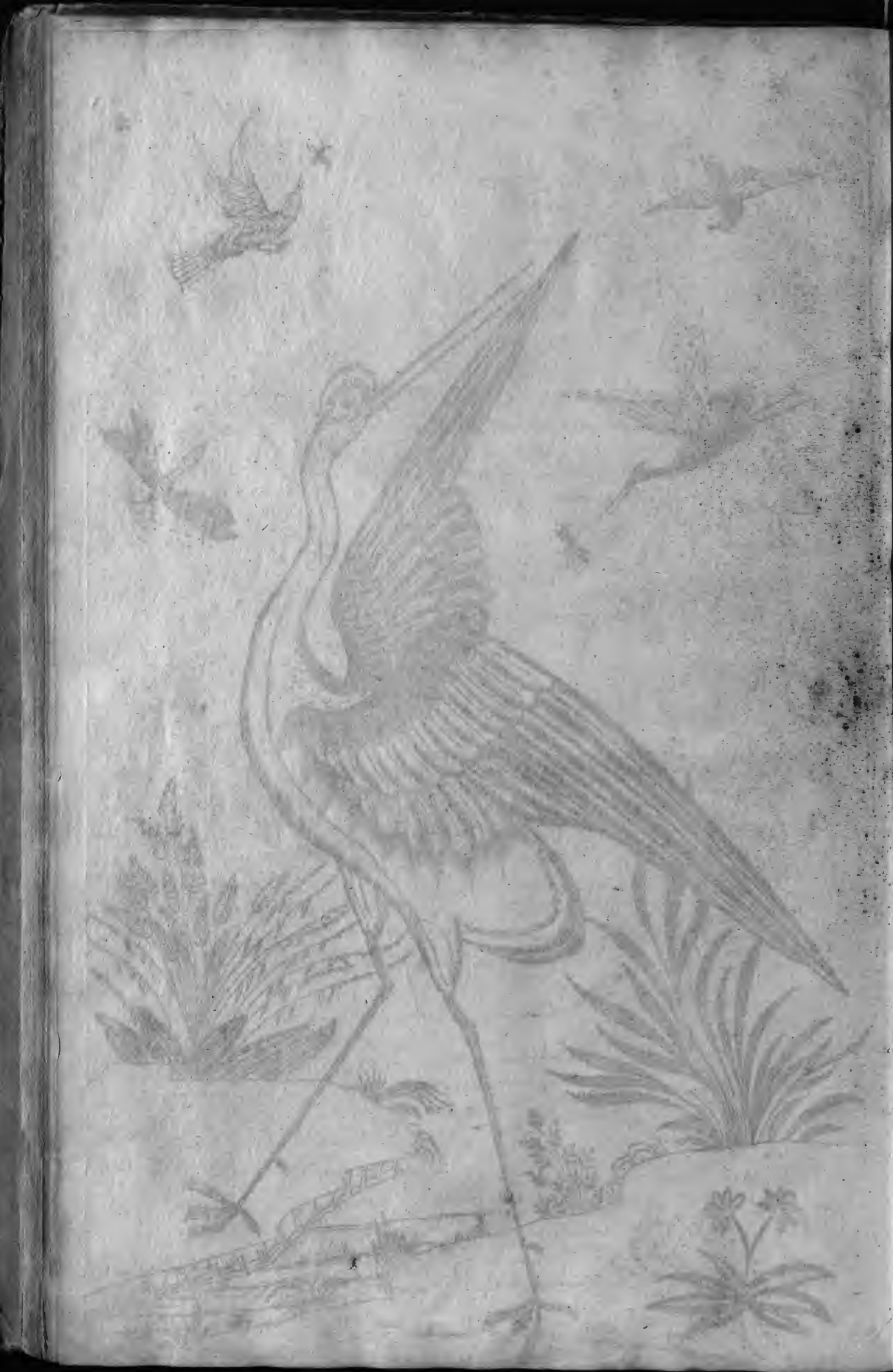




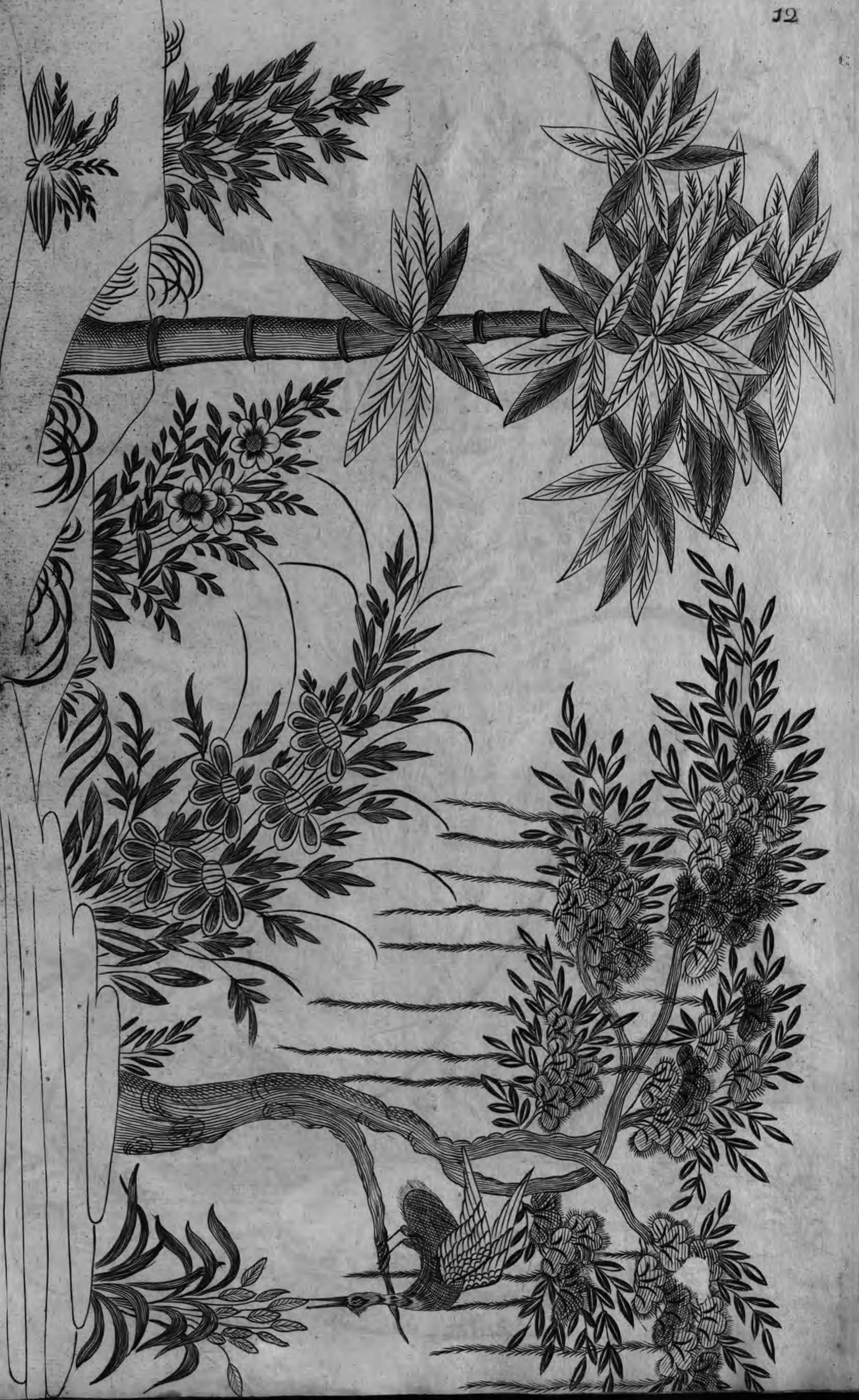




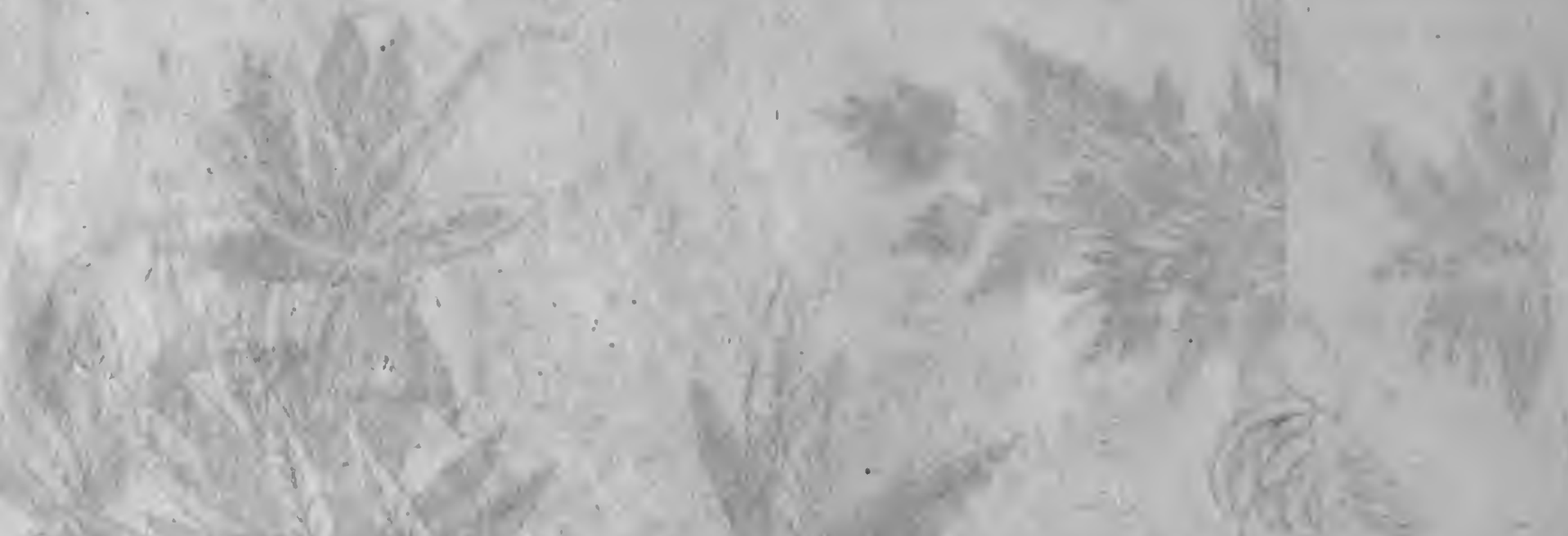

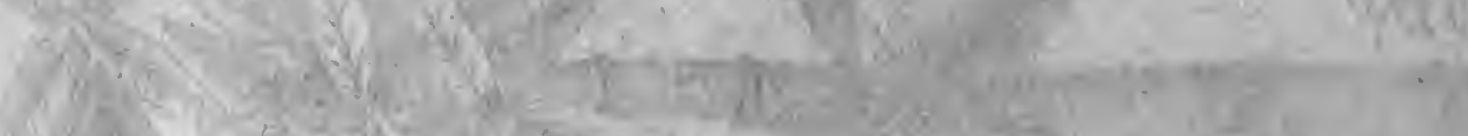

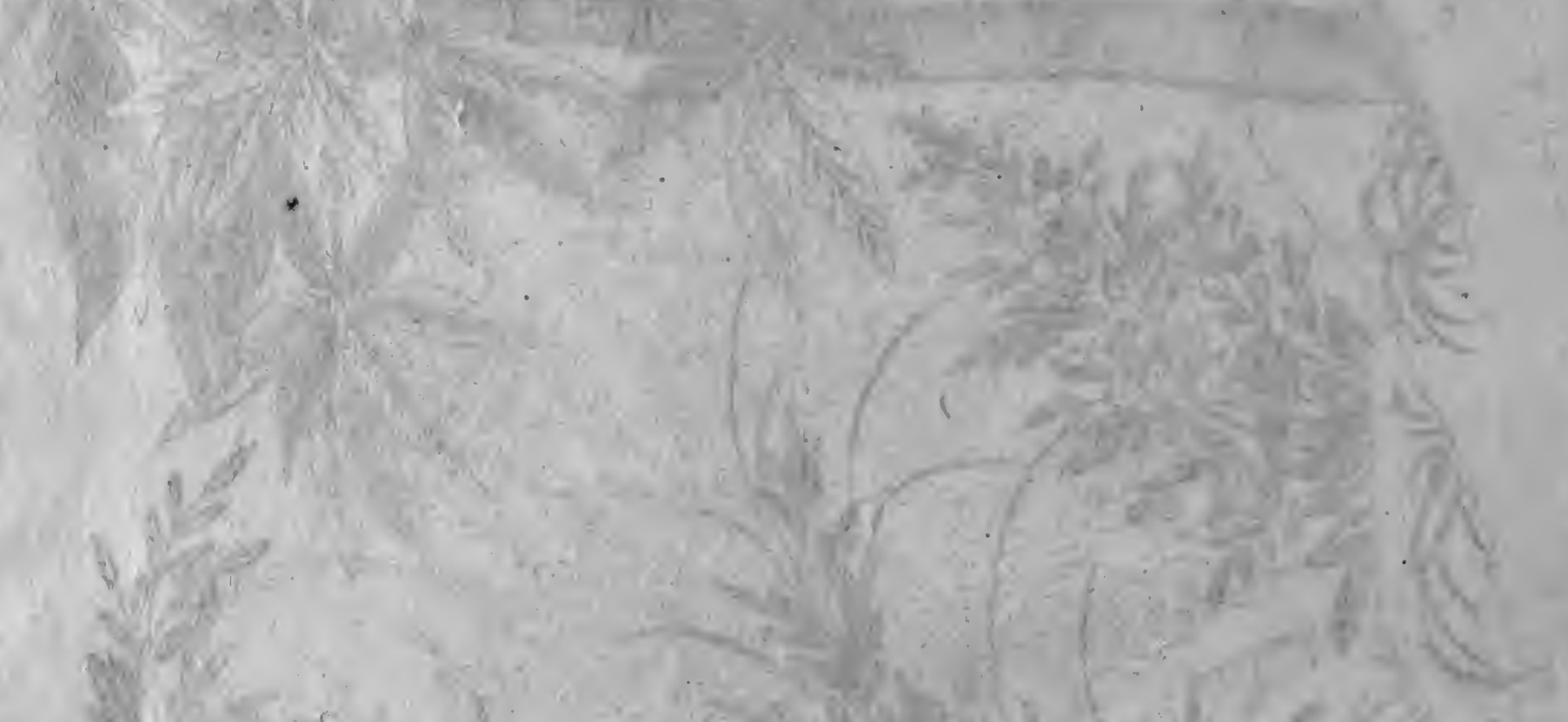
mơ

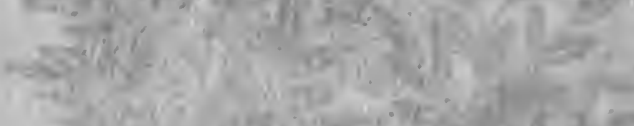

(3)

419
24

ats 


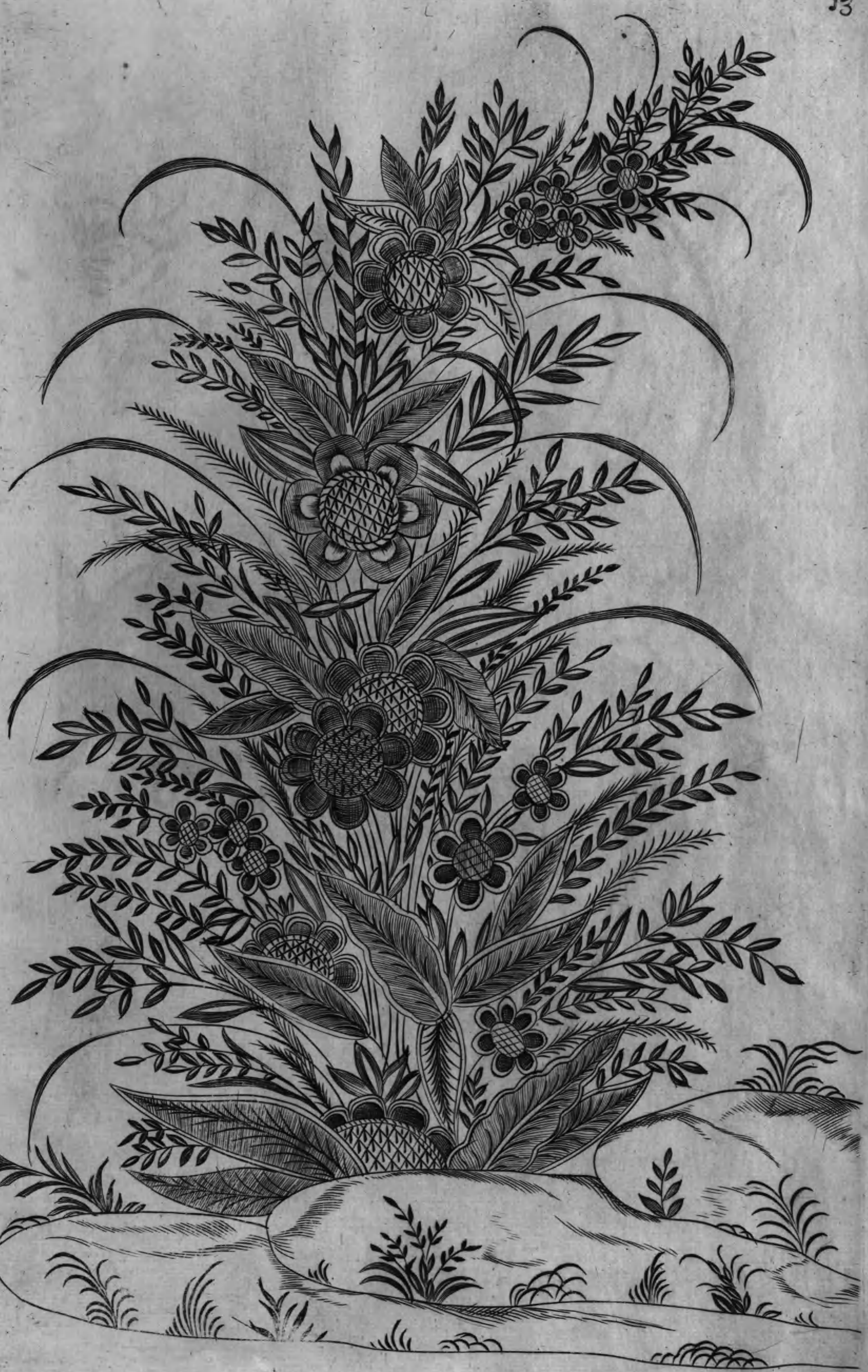





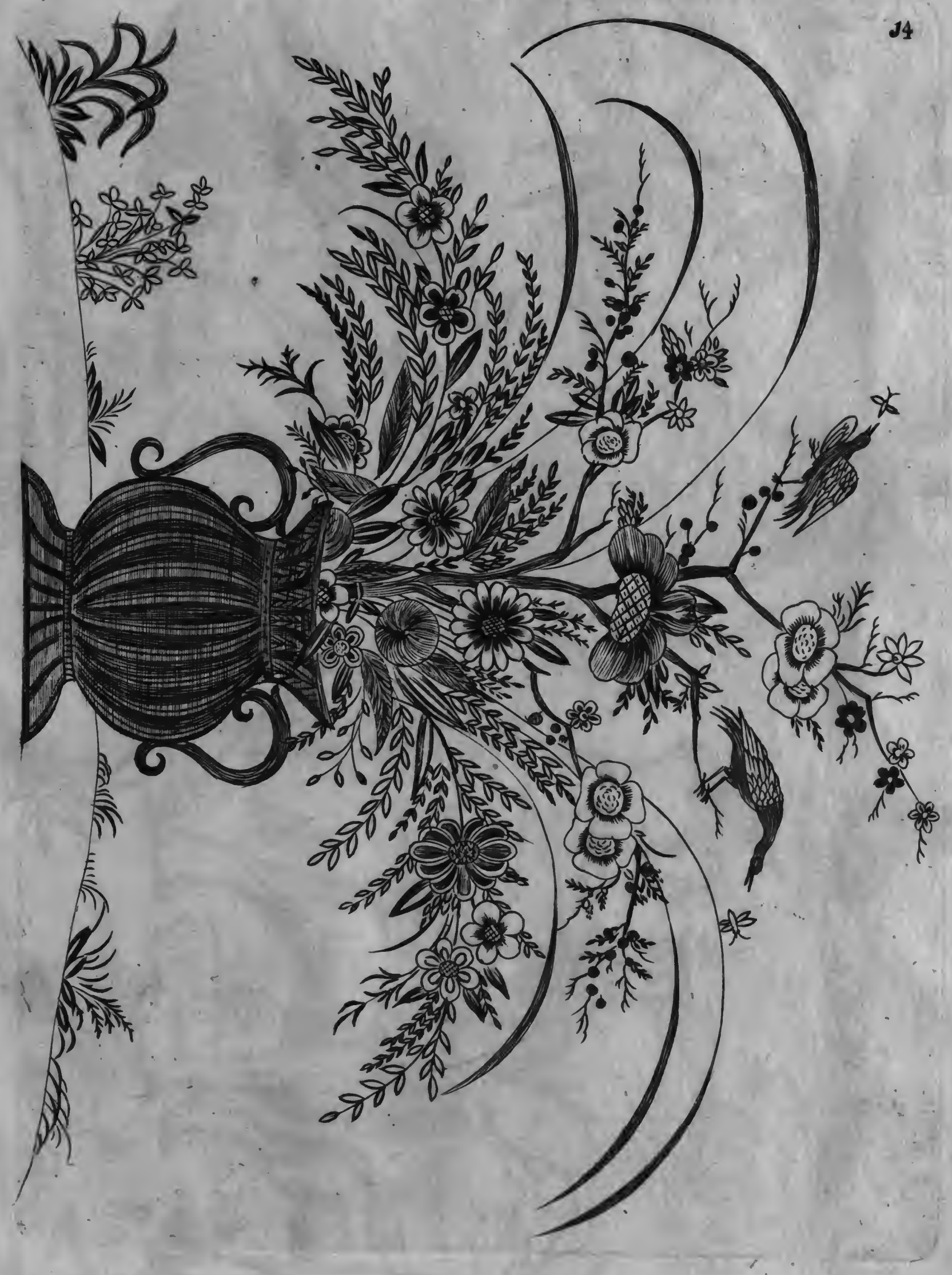


5

14
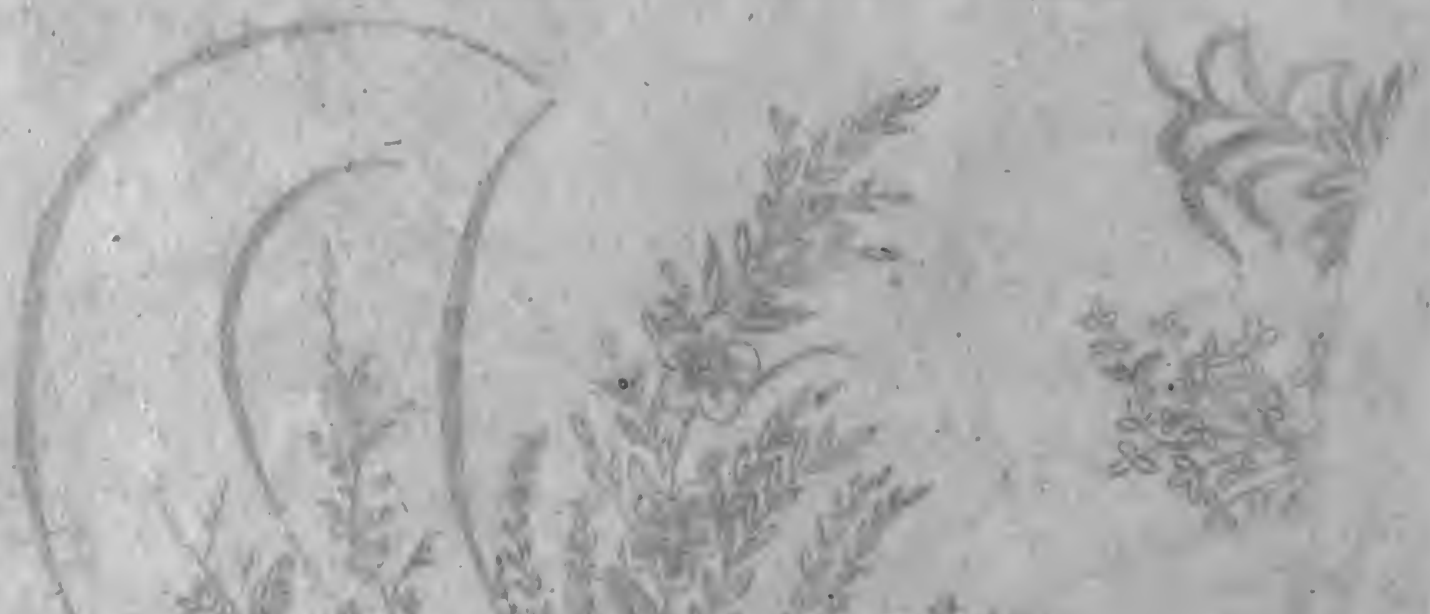

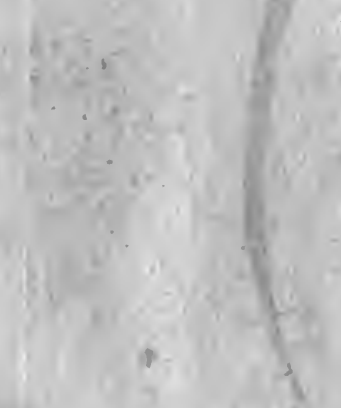

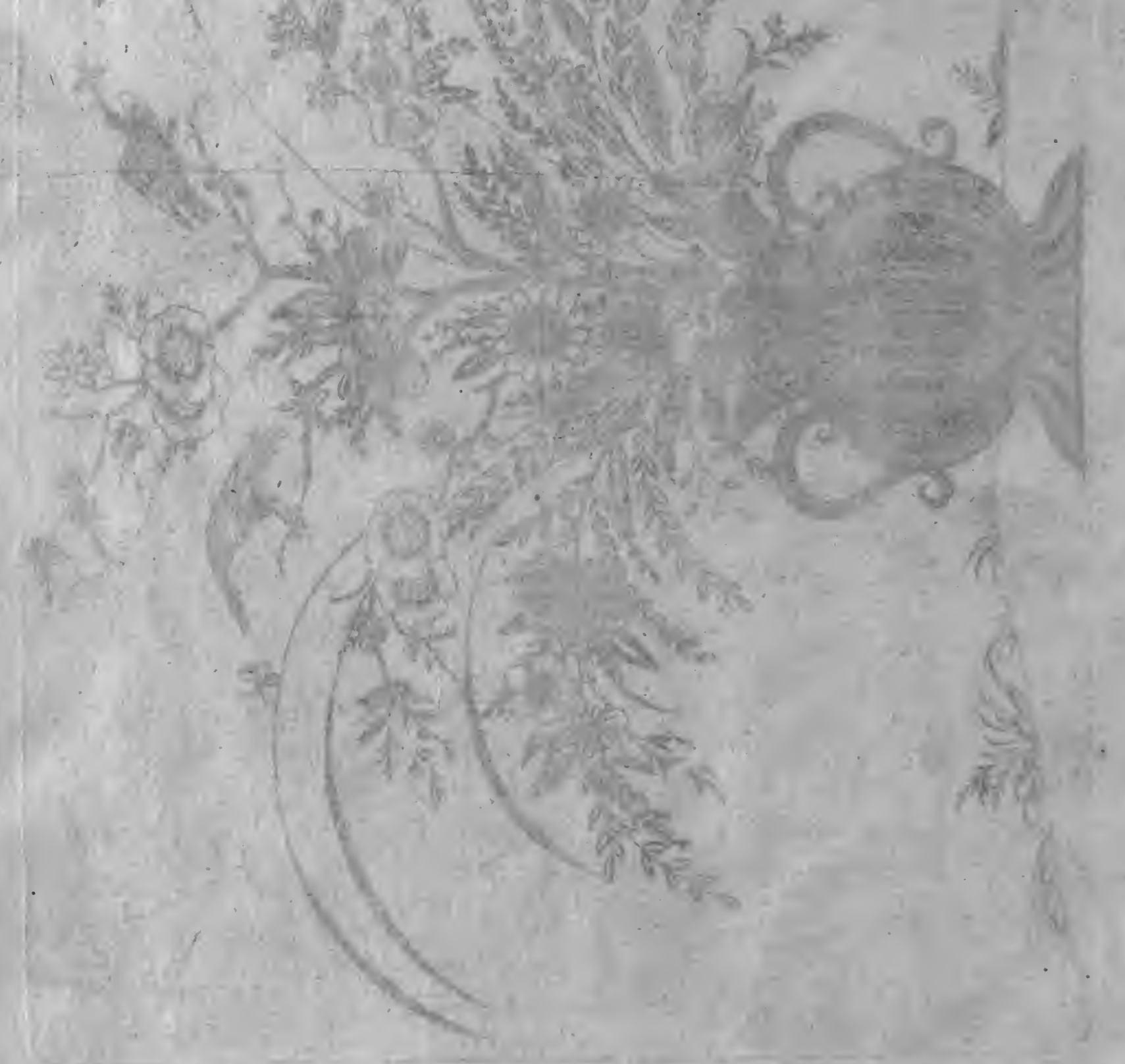




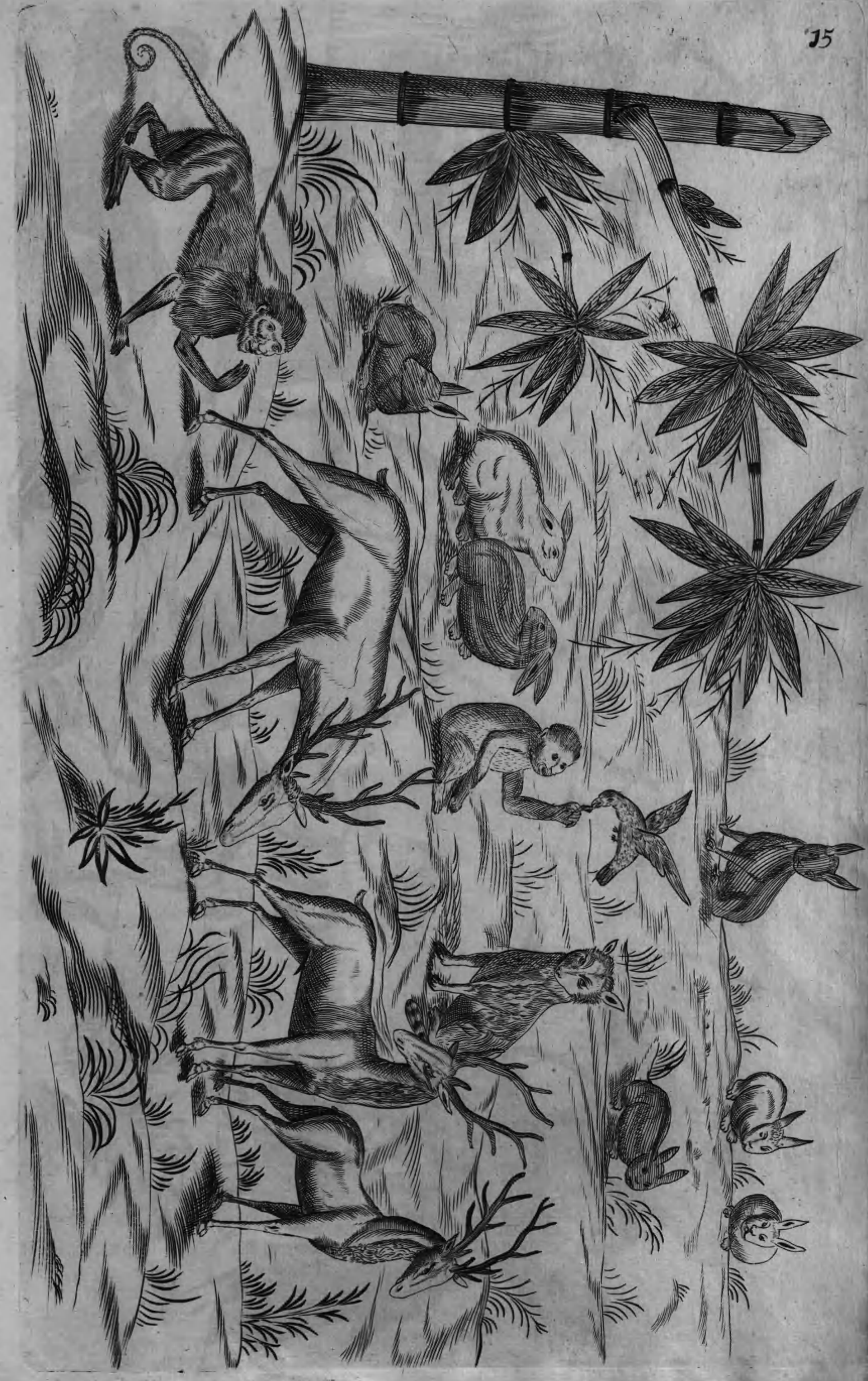


at?
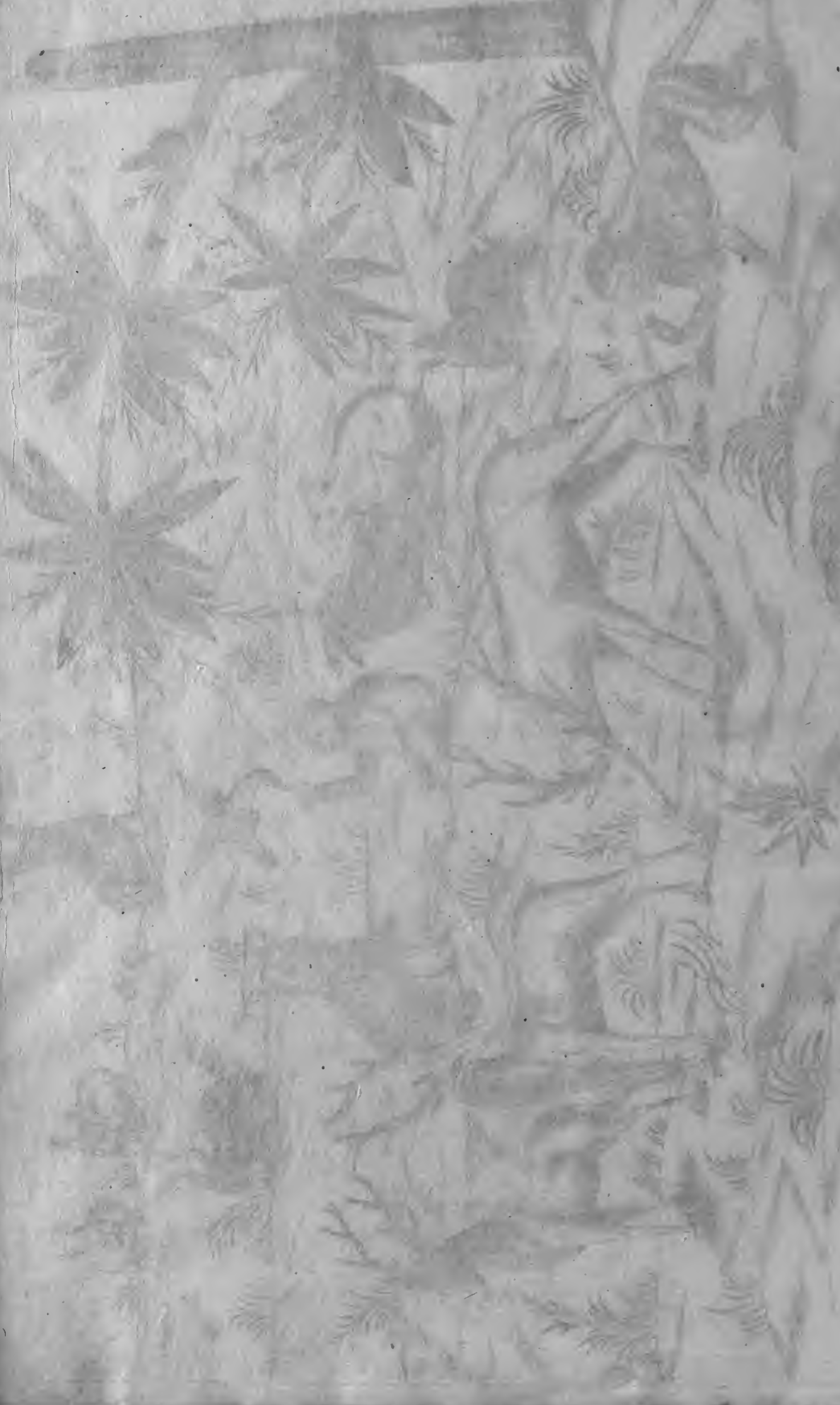


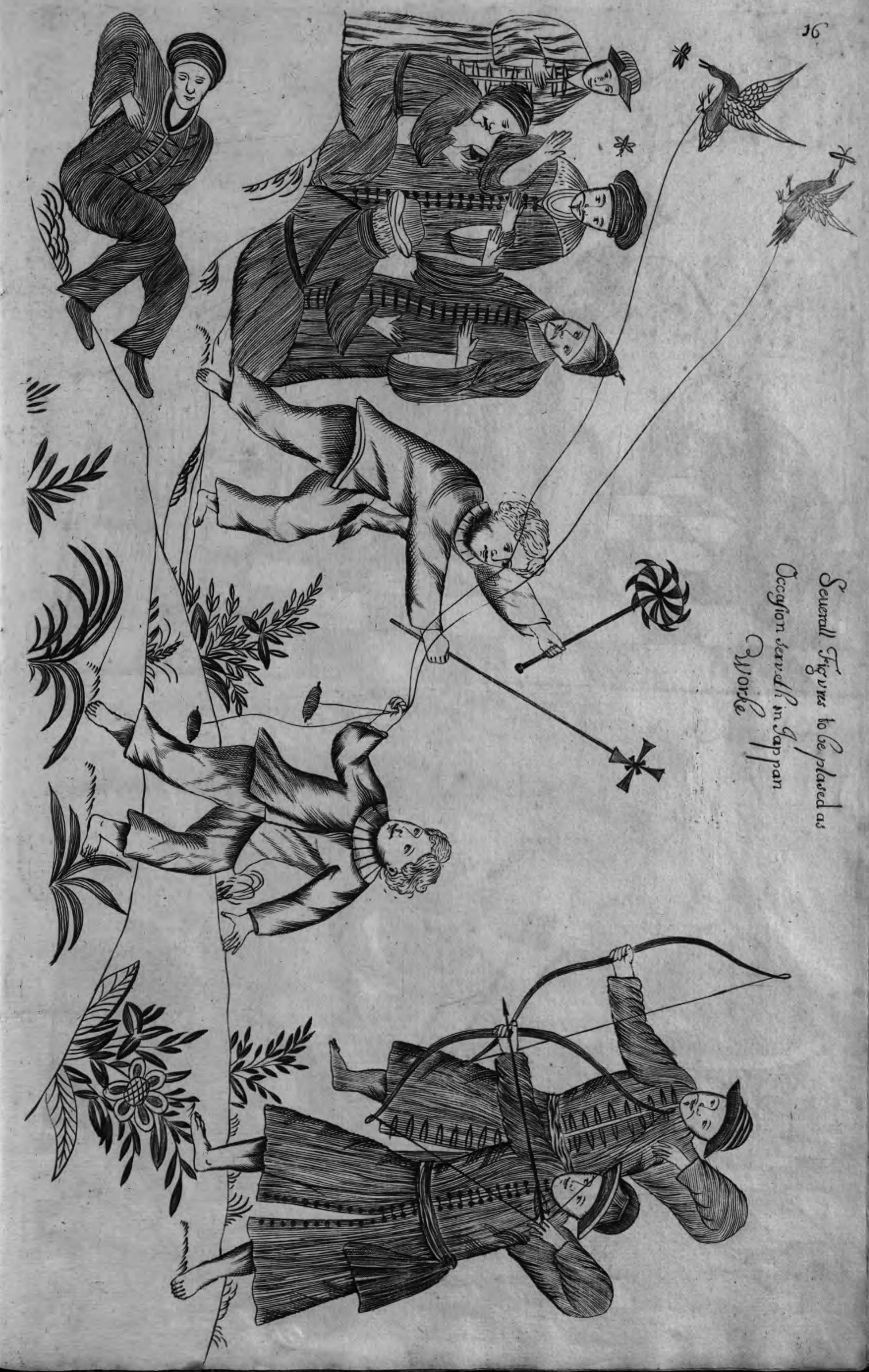



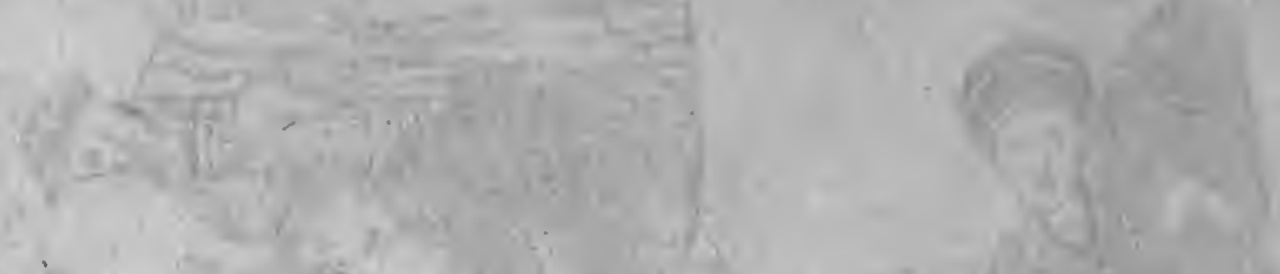

(i)

ina $5 \mathrm{c}$

s)
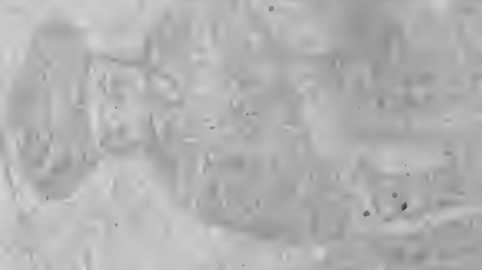

-1.jon

$\frac{4}{4}+20$
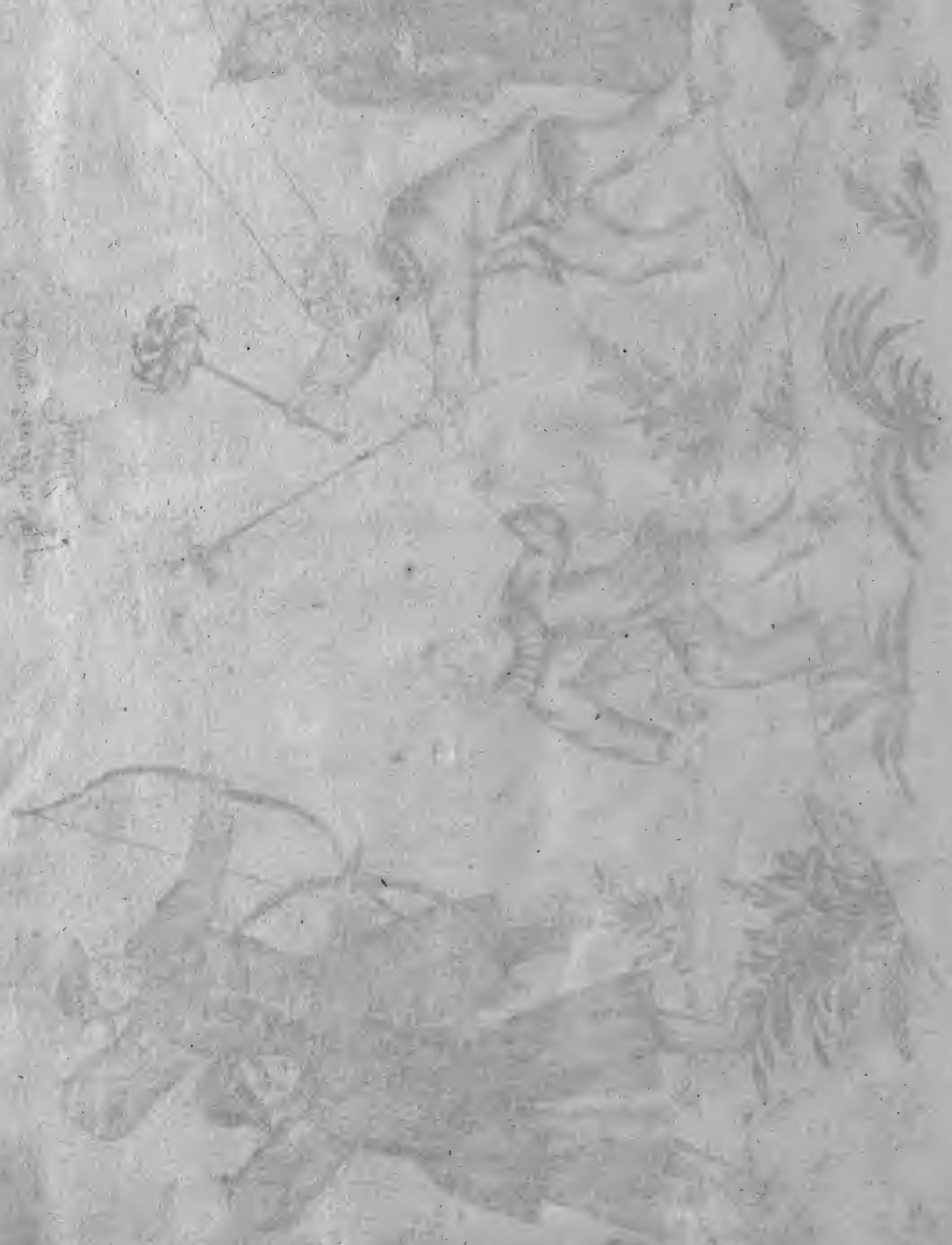


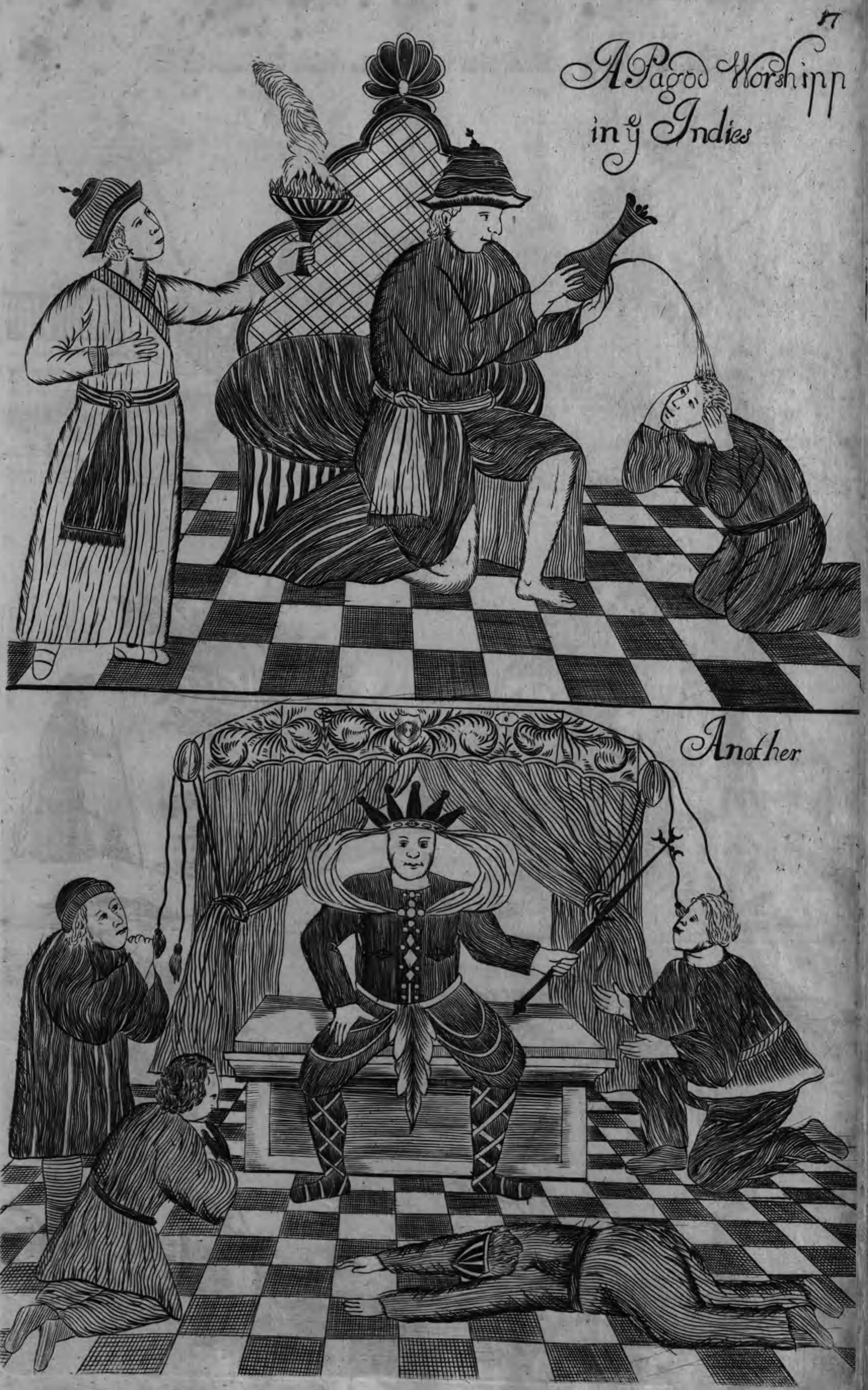



For Dravers for Cabbinds to b. Placed accorving to yor fancy
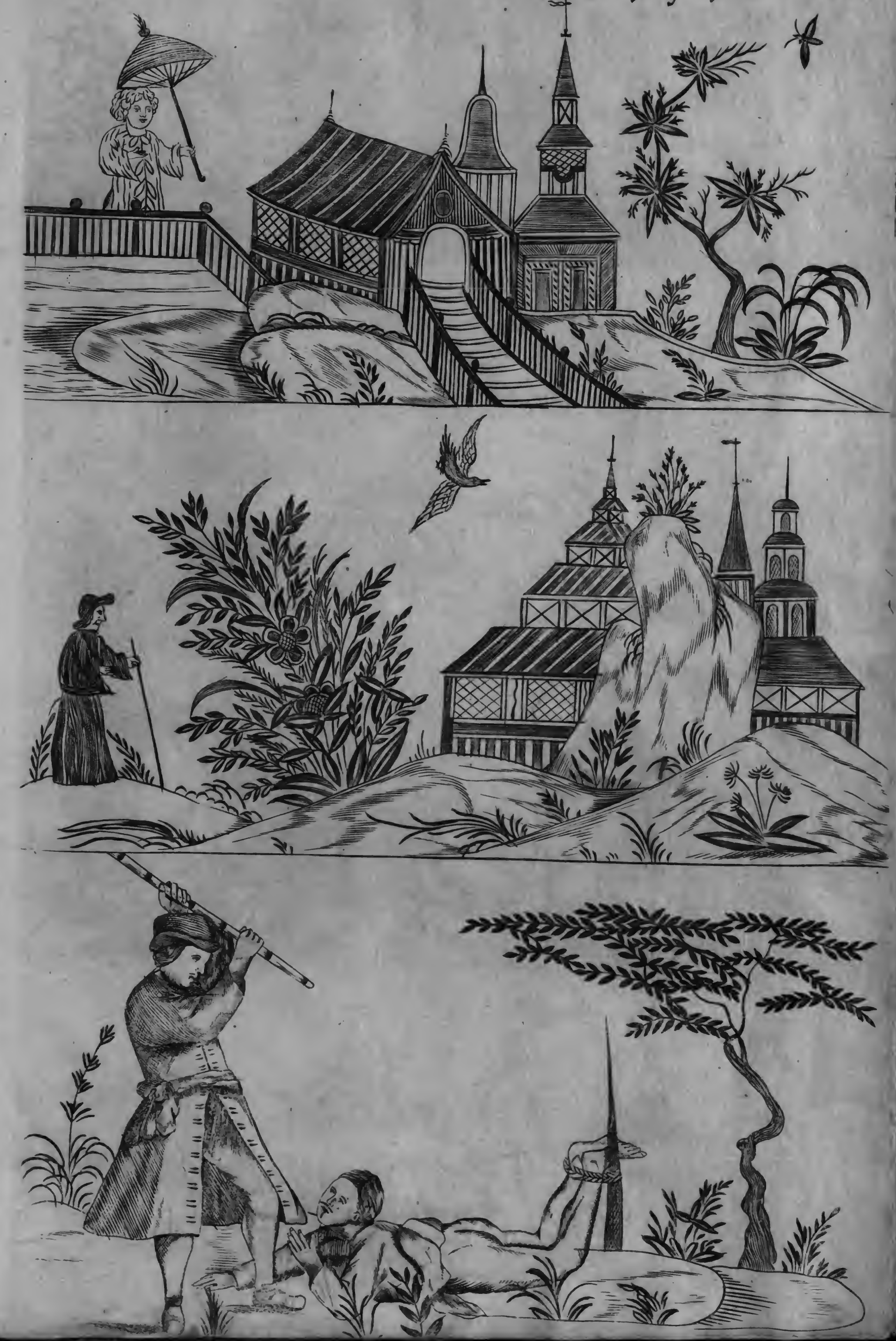


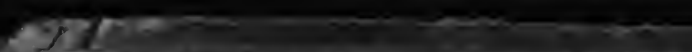


of Drausers som are Deepe \&s som move narrow of y Jame Cablinett

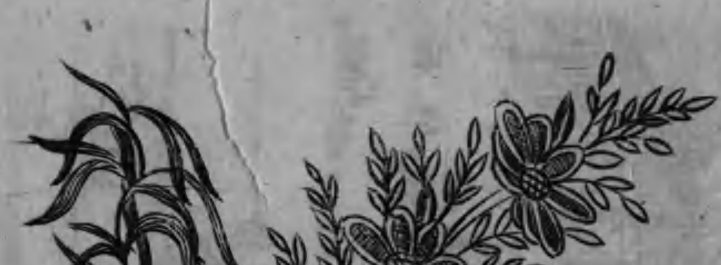

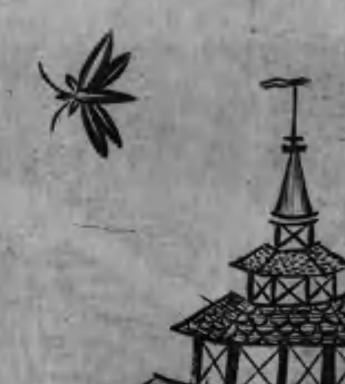

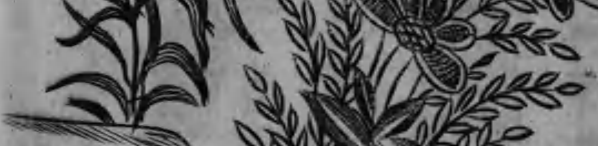

TIX 10

तथ

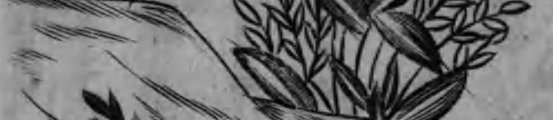

(y)

mines

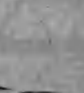

-

1. $=1$

in

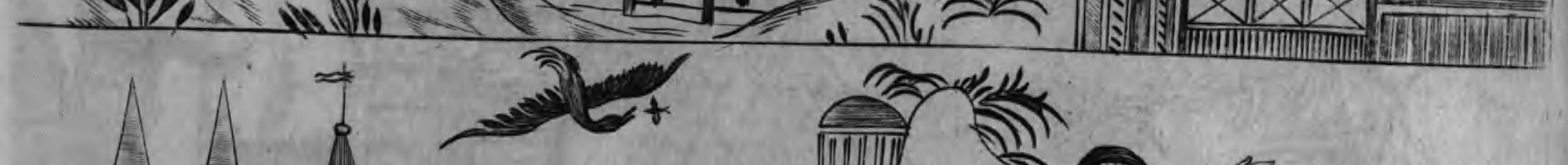

部业

(1)

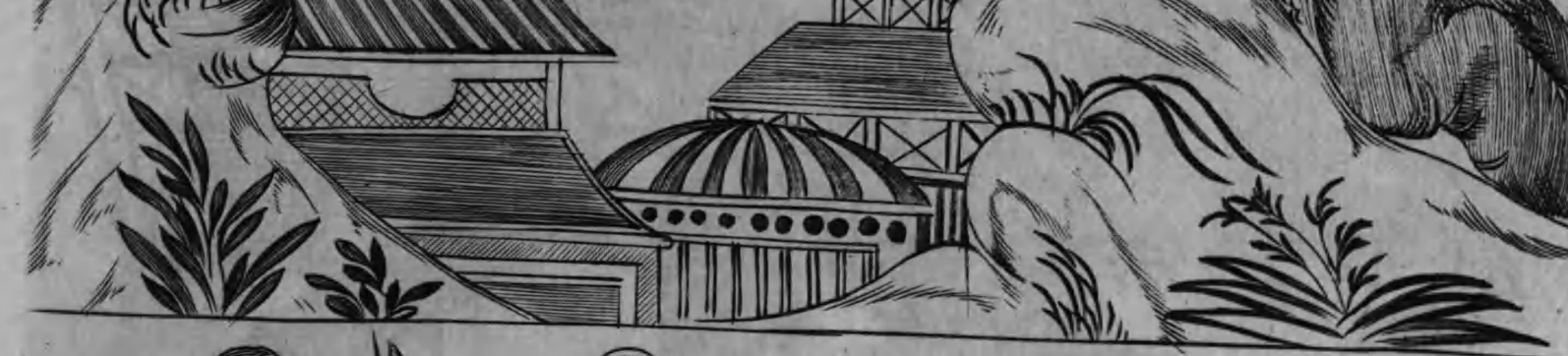
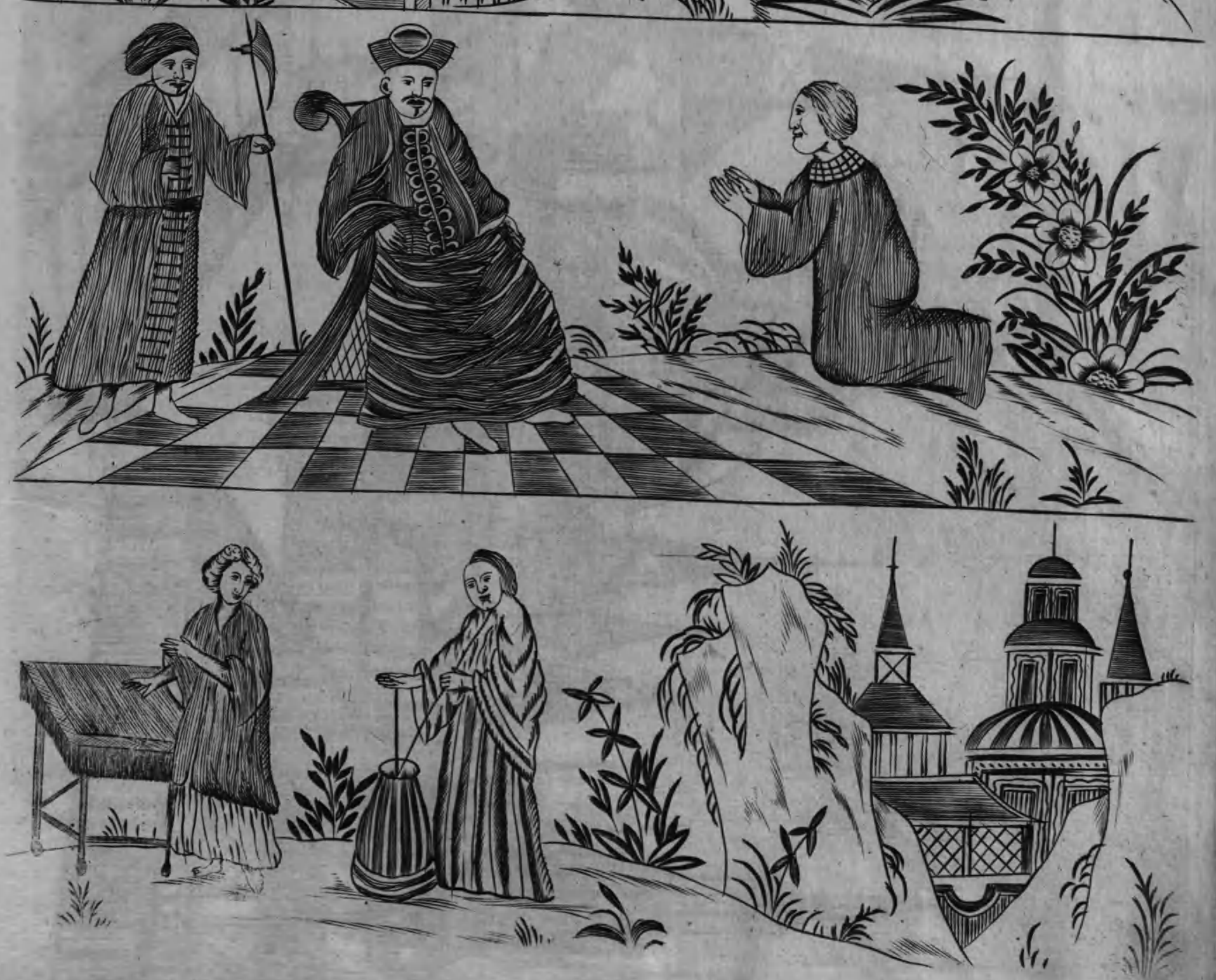


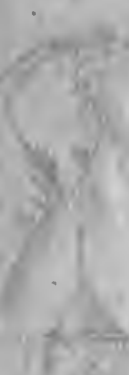

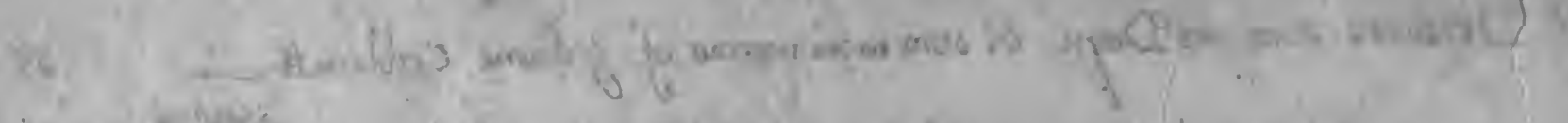

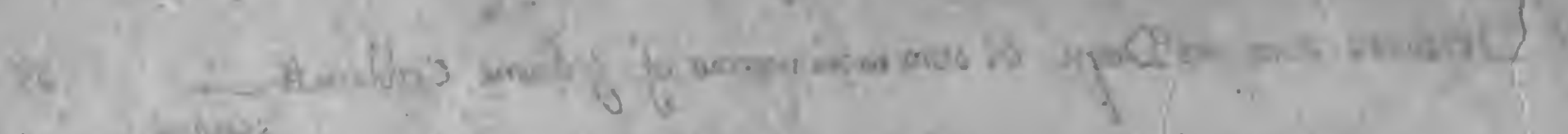
tist

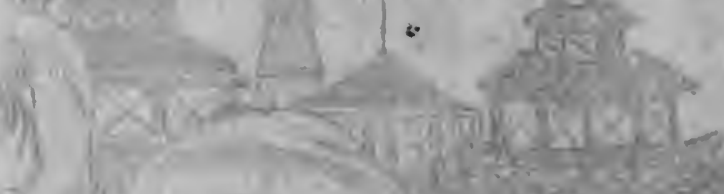

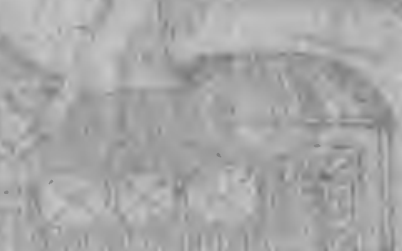

$$
\begin{aligned}
& \text { is of }
\end{aligned}
$$

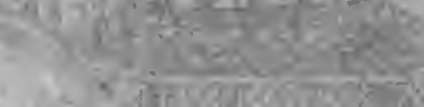

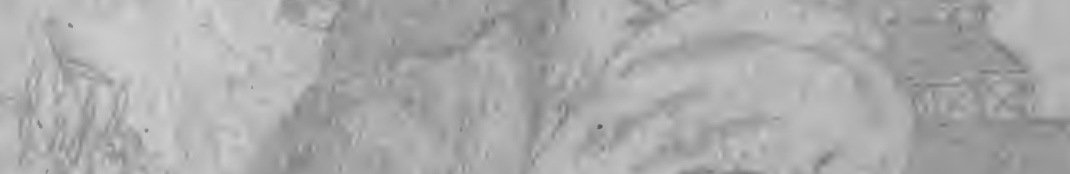

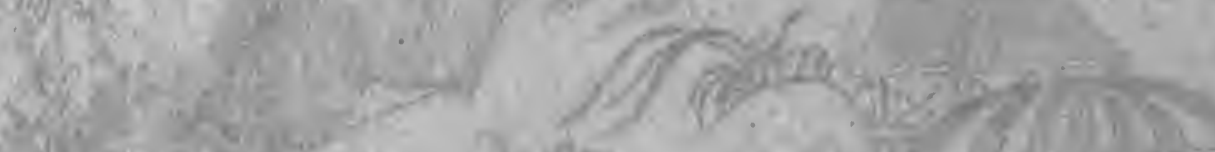

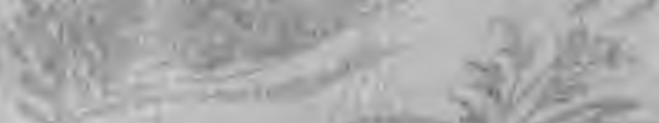

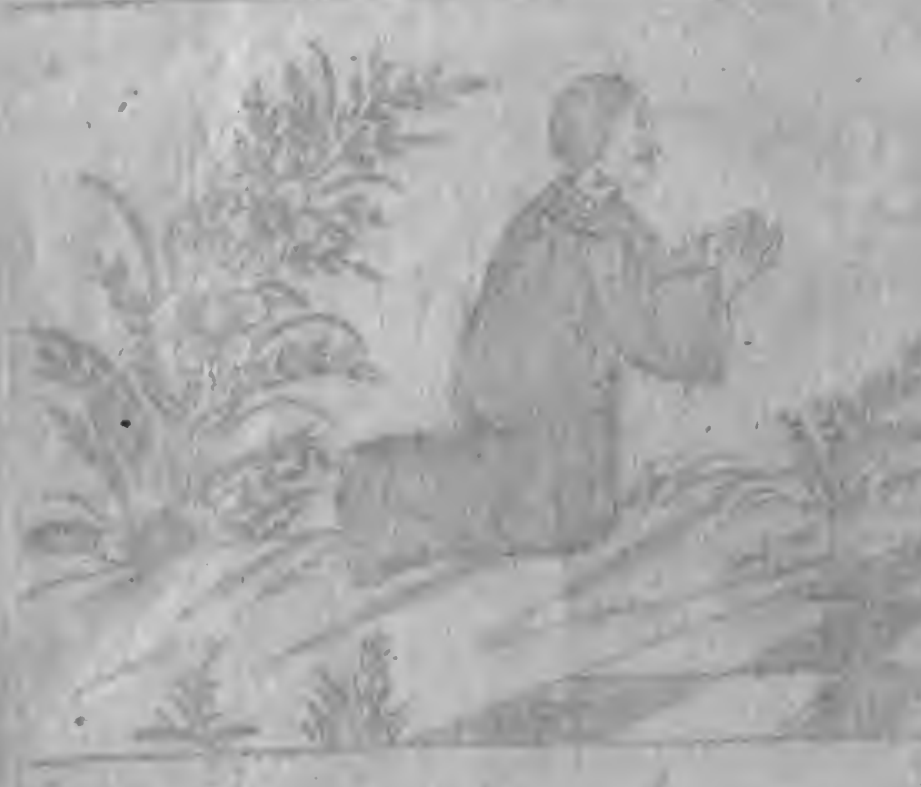

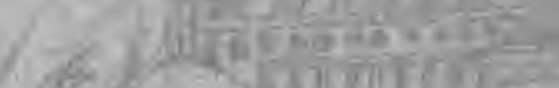

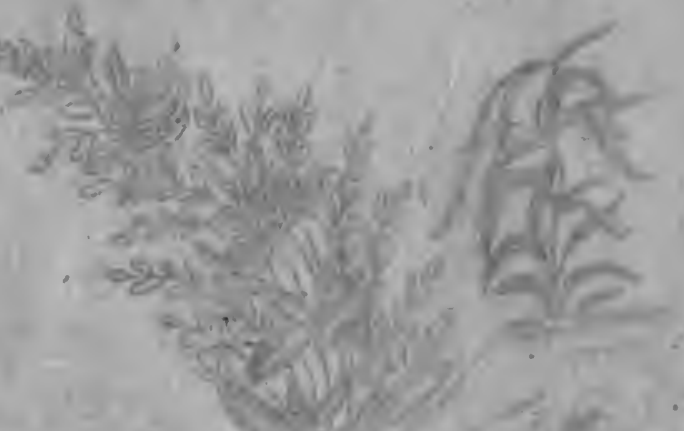
Q3.
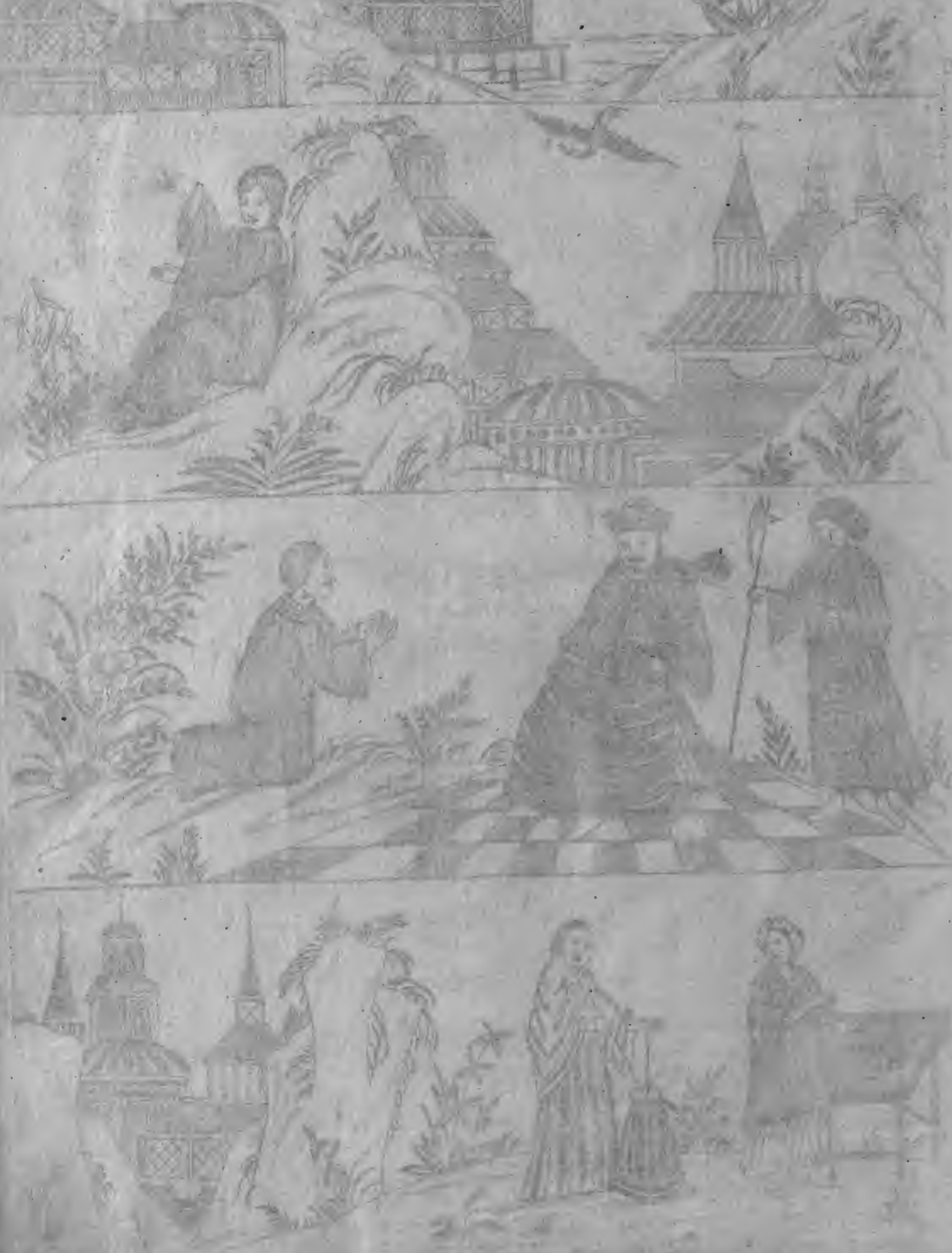


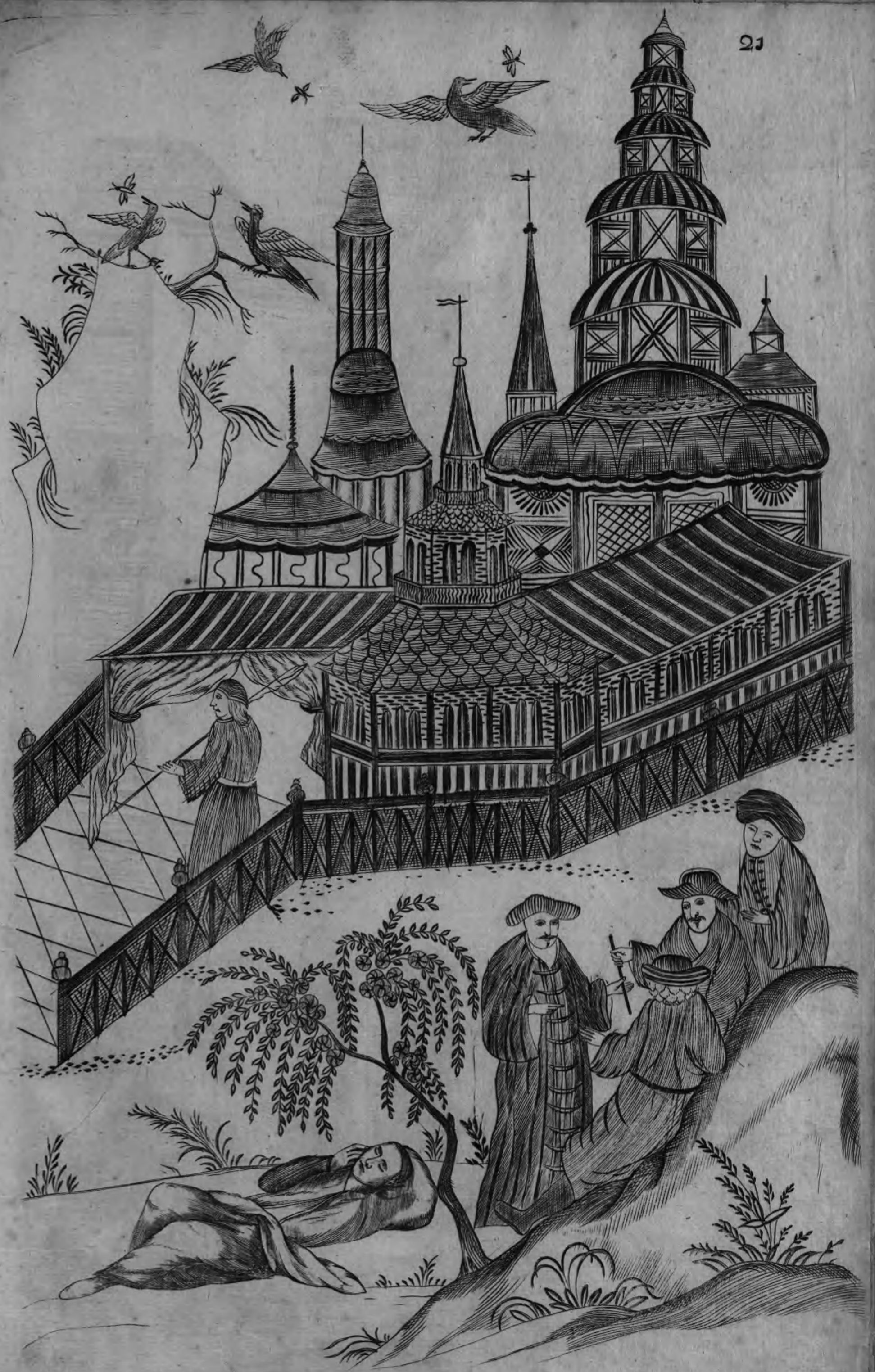




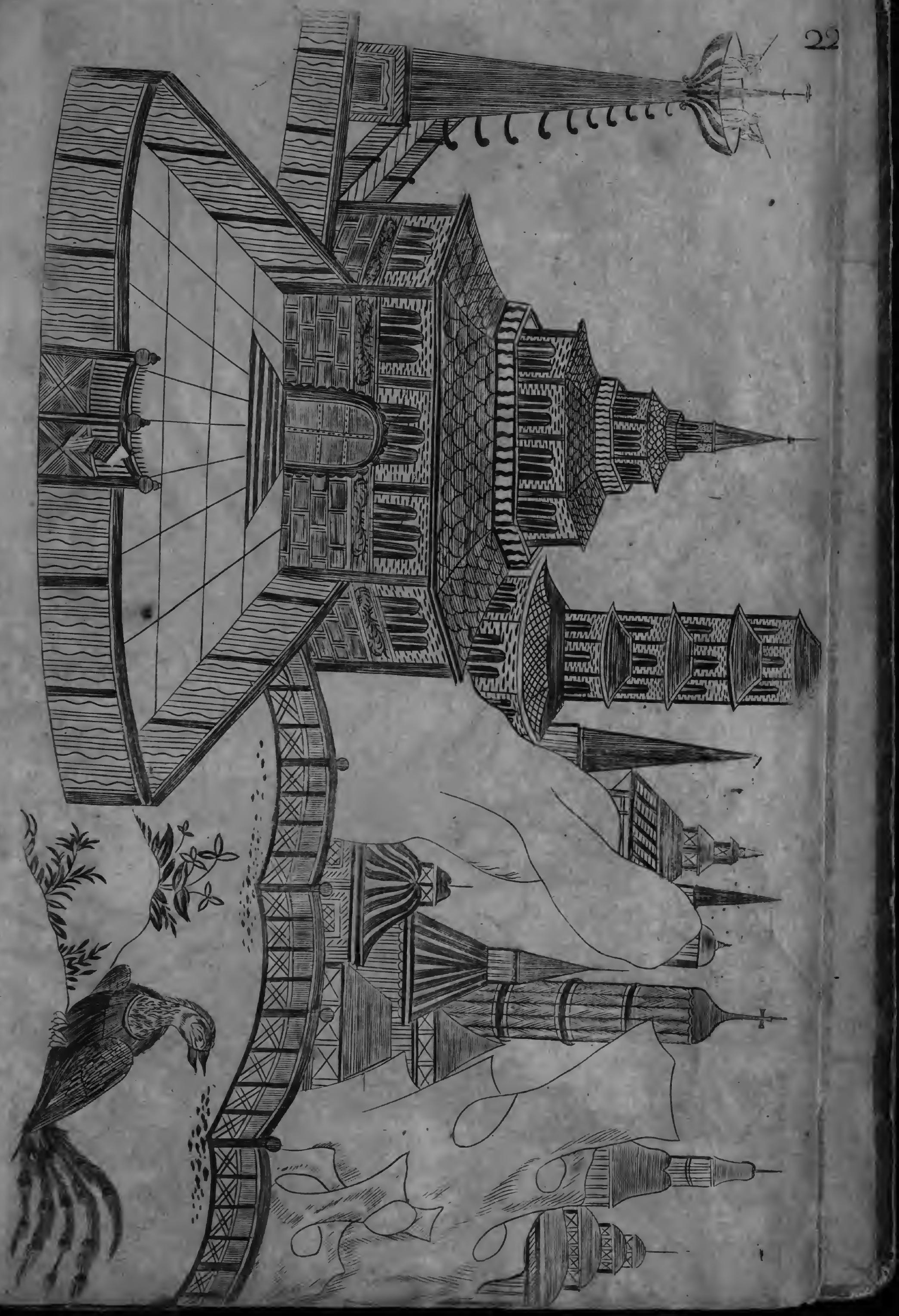




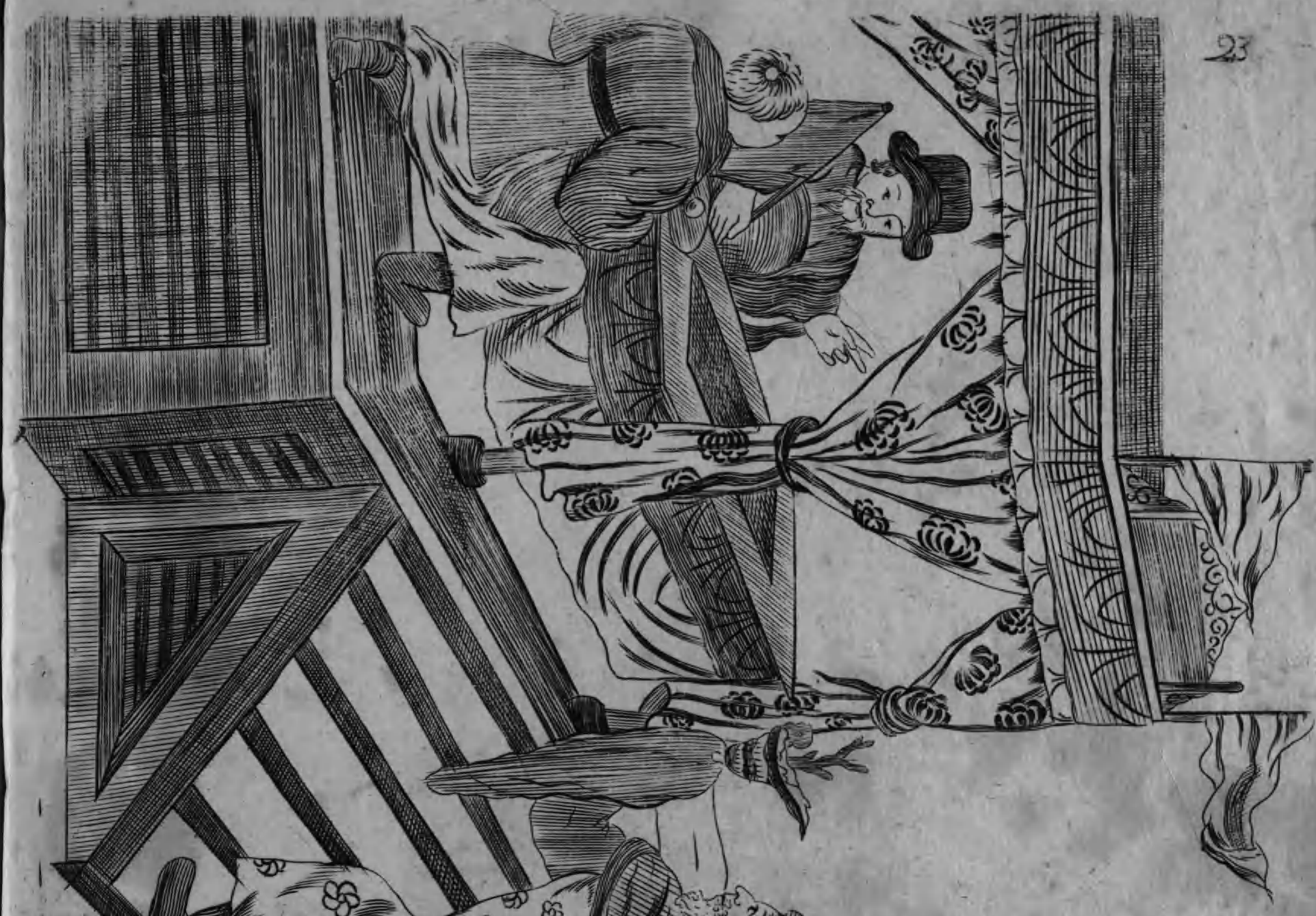

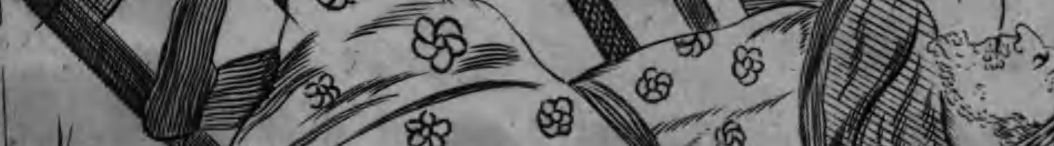

.

1

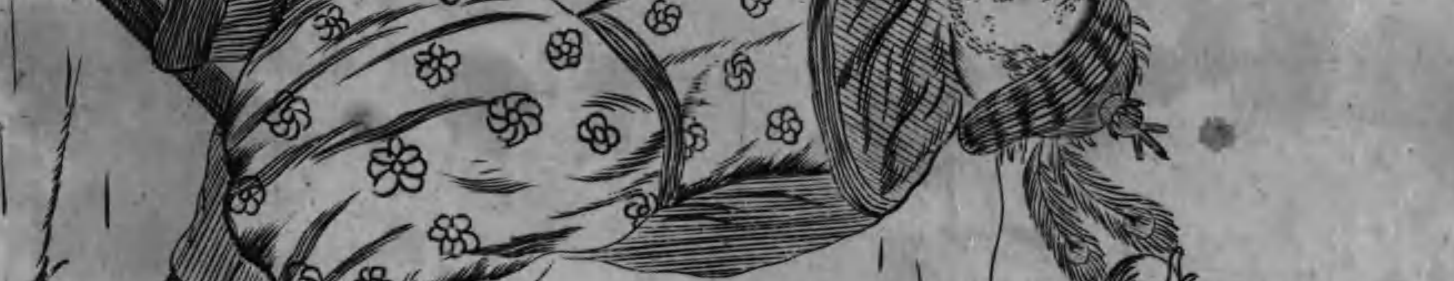

径
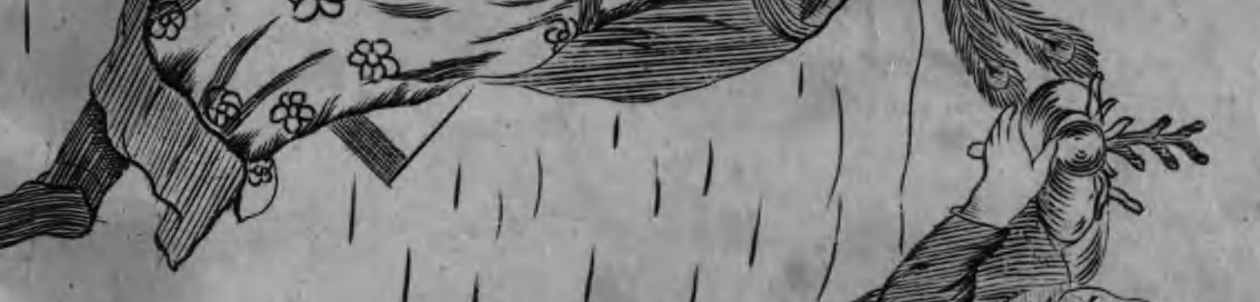

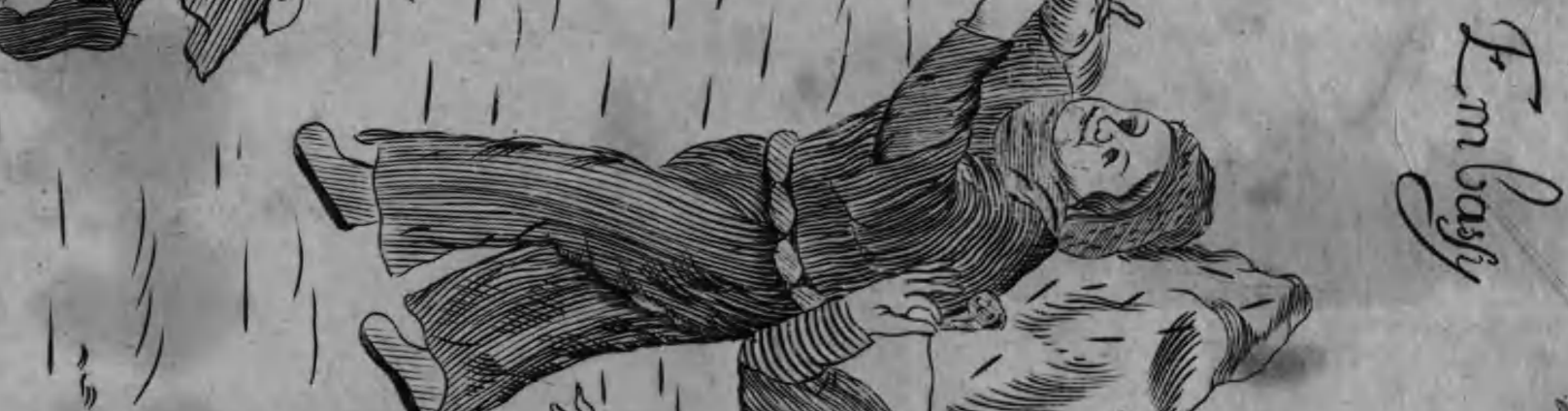

$\frac{2}{6}$

,

1

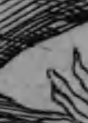

is 1

$-12$

(i)

1 10

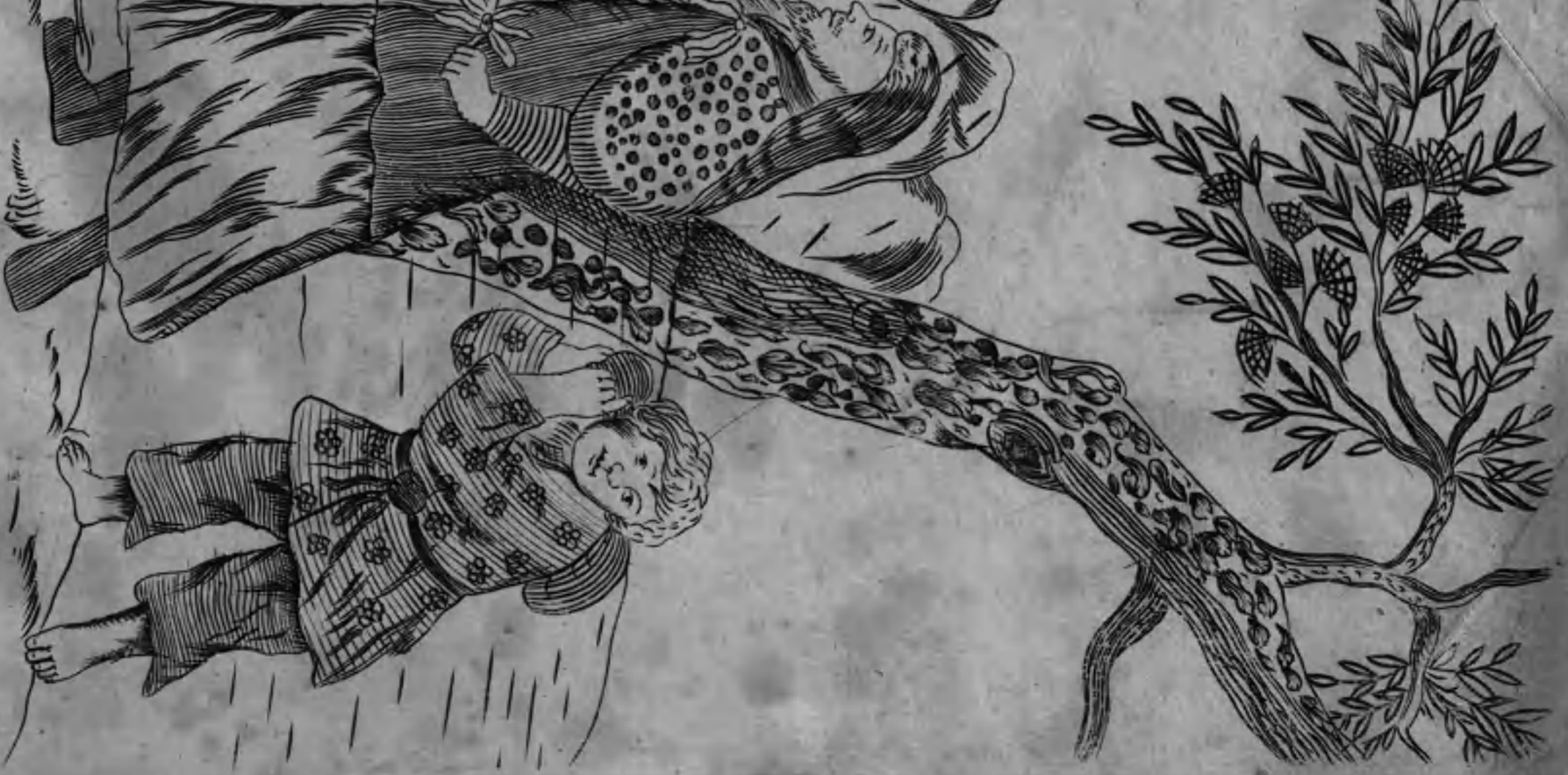




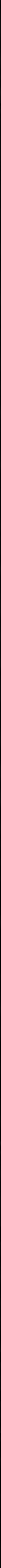




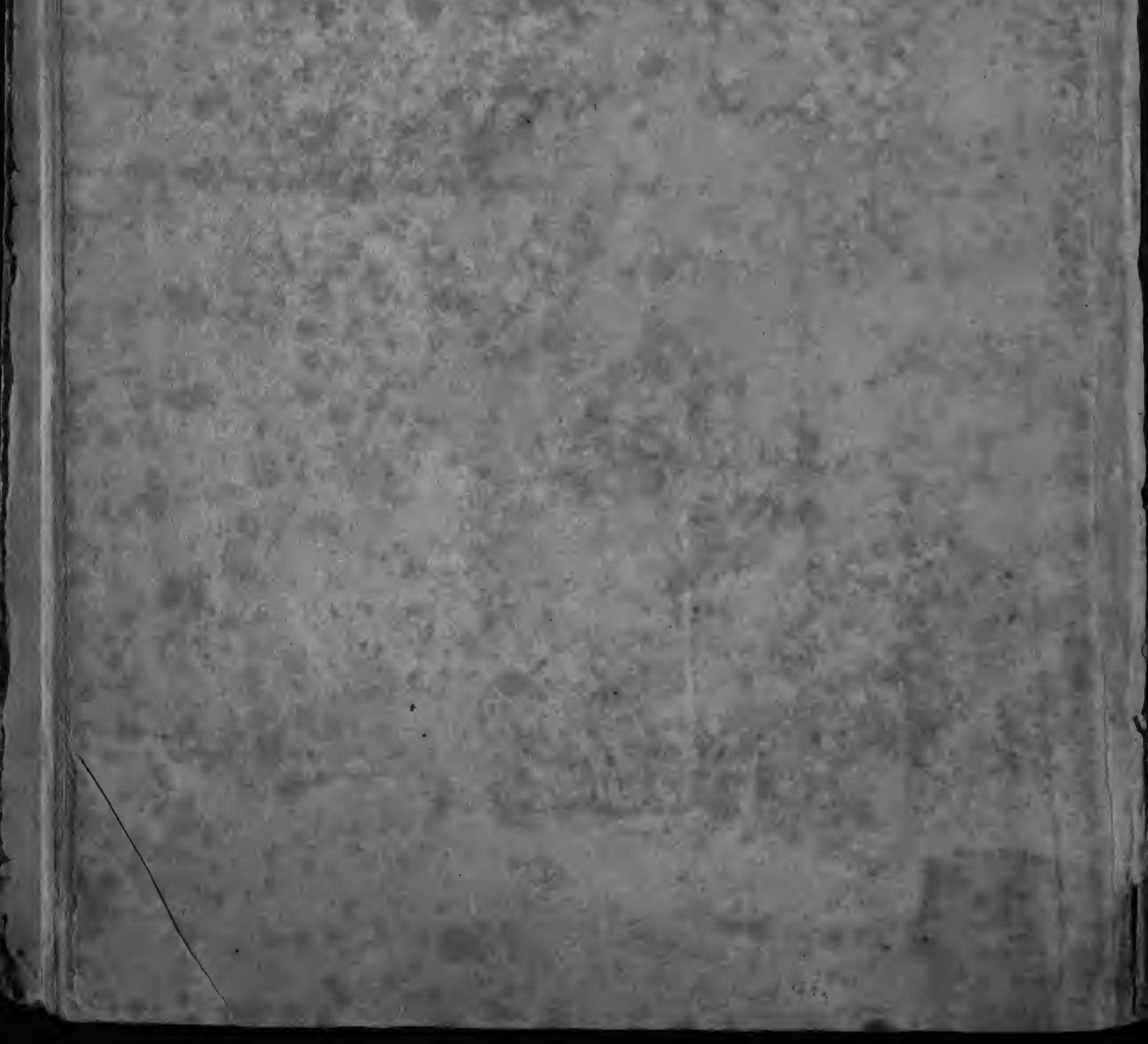


The

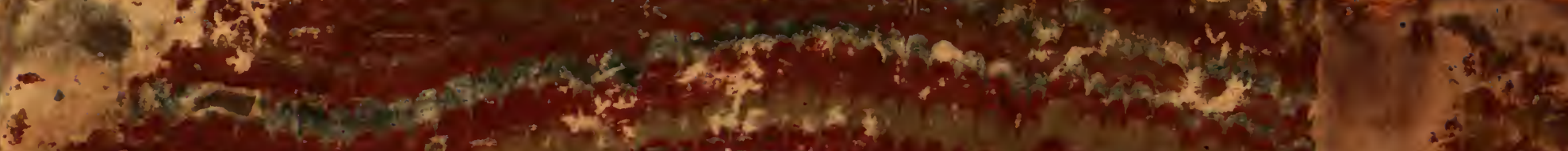

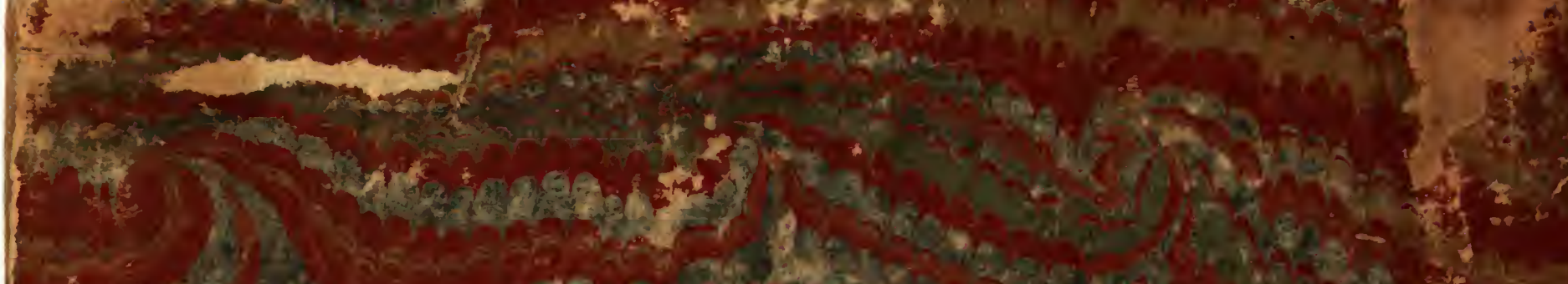

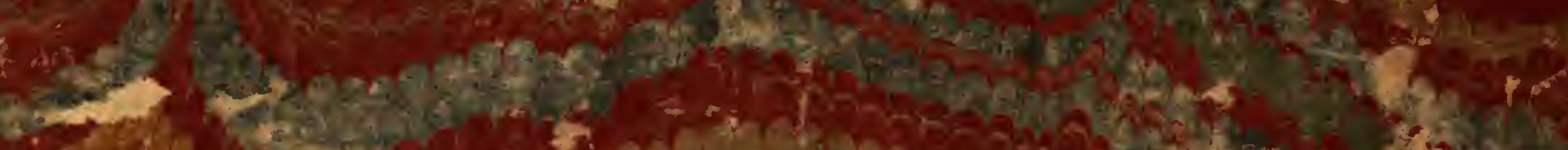

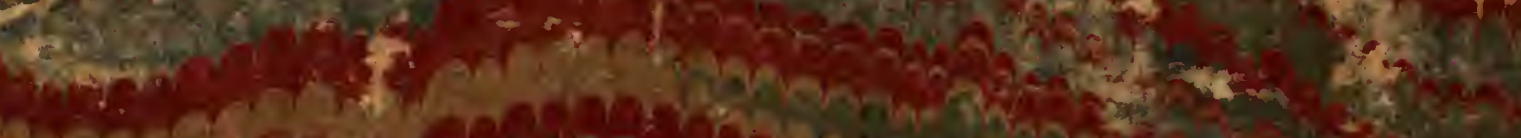

6.0.

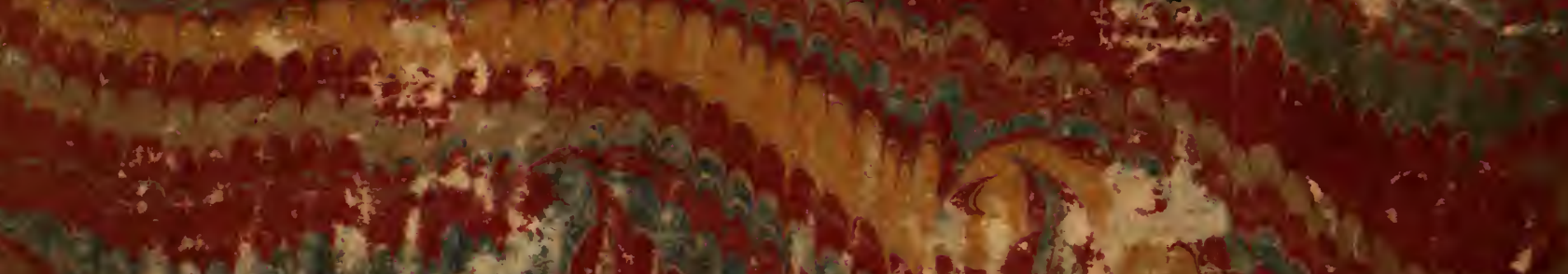

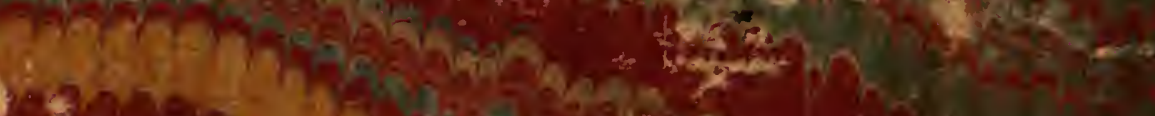

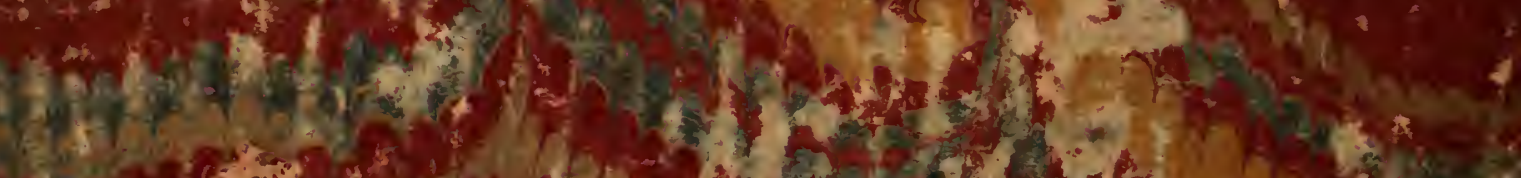

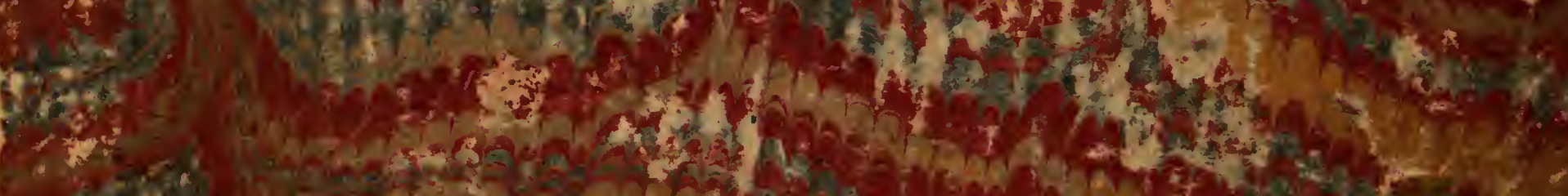

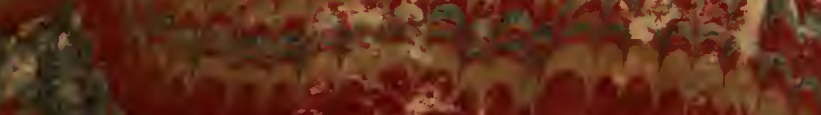

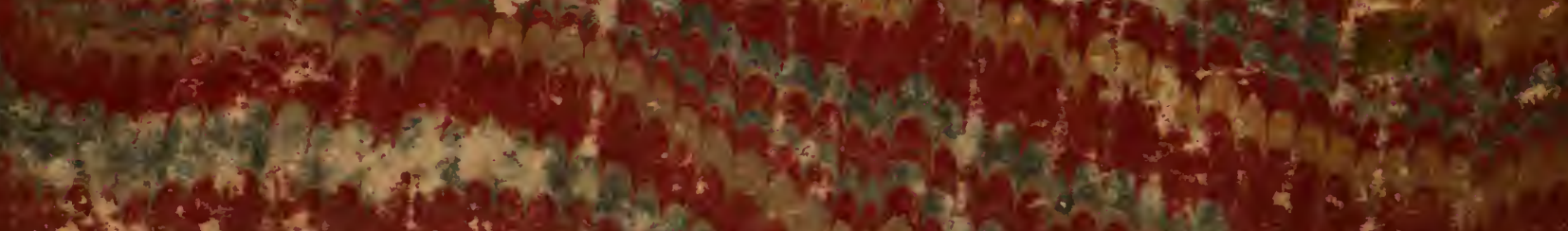

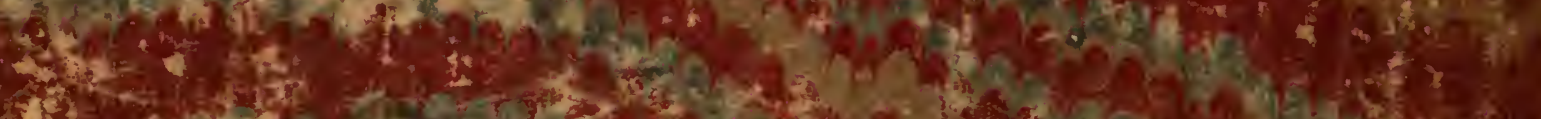

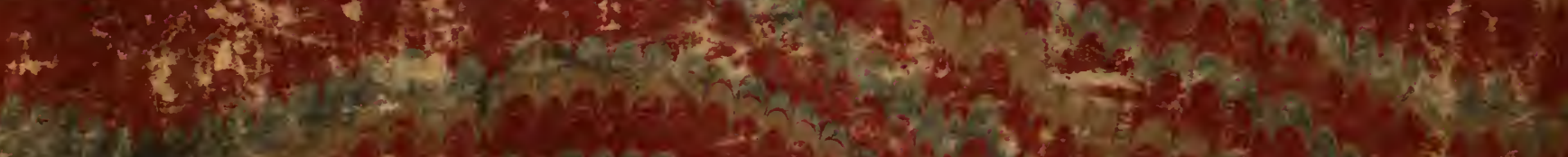

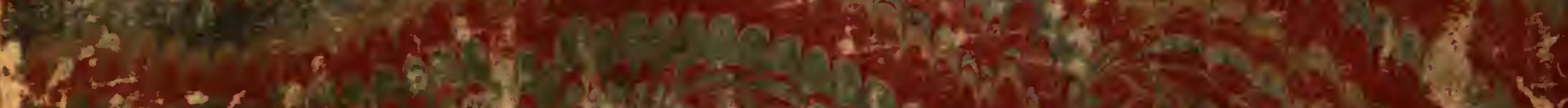

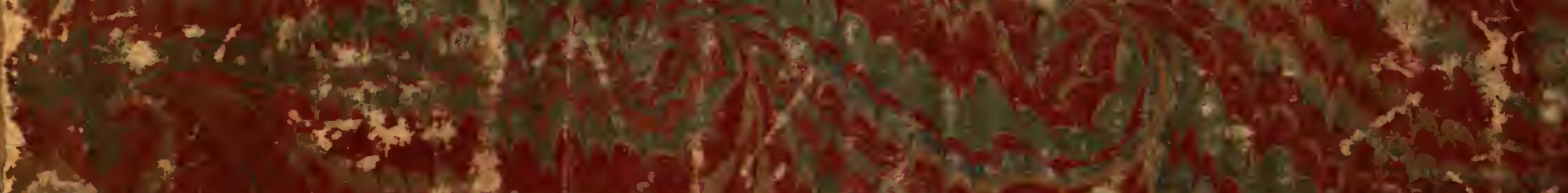
2

$-1 x^{3}$

Ching

t.

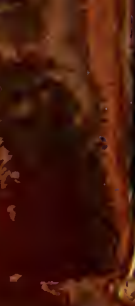

totat 